Routledge Innovations in Political Theory

\title{
THE LEGITIMACY OF MODERN DEMOCRACY
}

A STUDY ON THE POLITICAL THOUGHT OF MAX WEBER, CARL SCHMITT AND HANS KELSEN

Pedro T. Magalhães
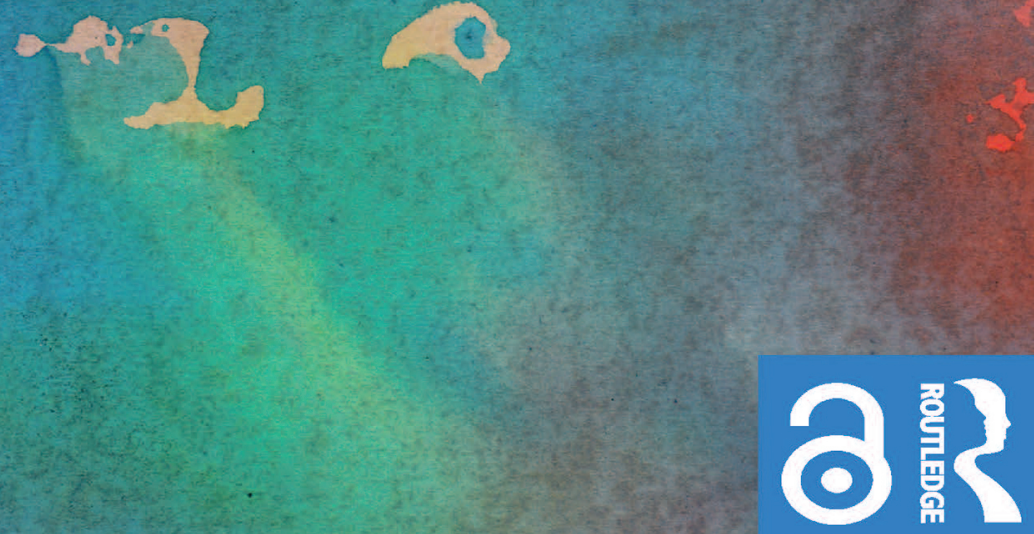
"Pedro Magalhães offers a personal reading of the works of three trained German jurists: Max Weber, Carl Schmitt and Hans Kelsen. He regards legitimation as a key to their vision of politics. Weber as theorist of action focused on daily debates of politicians, whereas Schmitt reduced politics to dramatic decisions on enmity and exception and Kelsen justified democracy with relativism."

Kari Palonen, Professor Emeritus, University of Jyväskylä

"The debate today over how democracy might die easily breeds the equal and opposite paralyses of complacency and fright. In this excellent book, Pedro T. Magalhães returns to three pivotal thinkers in the German tradition of conceptualizing the legitimacy of democracy, and argues that their Central European experiences and theoretical enterprise are relevant still. Through his sophisticated reconstructions, he shows that the urgency of our times can prompt deliberation and insight."

Samuel Moyn, Yale University

"A fresh and tough-minded reevaluation of liberal and authoritarian approaches to the state in Weimar political thought."

John P. McCormick, University of Chicago 

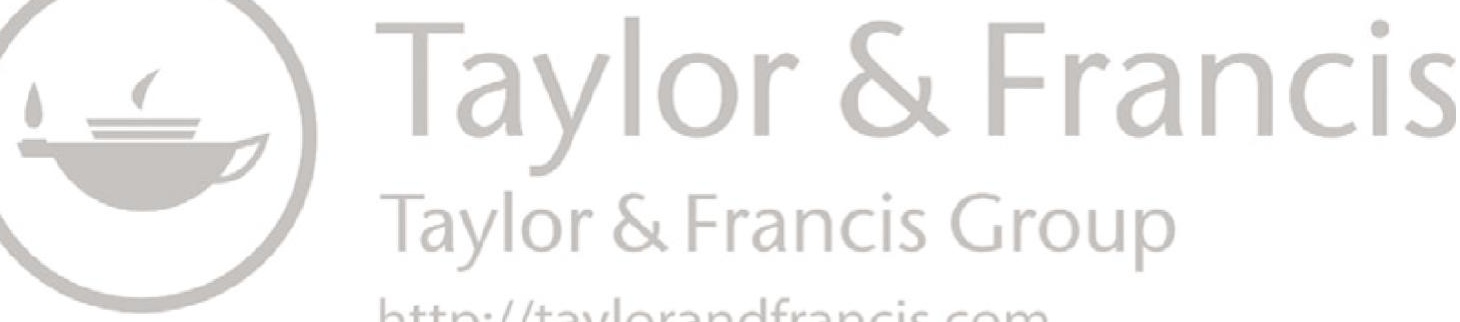

http://taylorandfrancis.com 


\section{The Legitimacy of Modern Democracy}

By re-examining the political thought of Max Weber, Carl Schmitt and Hans Kelsen, this book offers a reflection on the nature of modern democracy and the question of its legitimacy. Pedro T. Magalhães shows that present-day elitist, populist and pluralist accounts of democracy owe, in diverse and often complicated ways, an intellectual debt to the interwar era, German-speaking, scholarly and political controversies on the problem(s) of modern democracy.

A discussion of Weber's ambivalent diagnosis of modernity and his elitist views on democracy, as they were elaborated especially in the 1910s, sets the groundwork for the study. Against that backdrop, Schmitt's interwar political thought is interpreted as a form of neo-authoritarian populism, whereas Kelsen evinces robust, though not entirely unproblematic, pluralist consequences. In the conclusion, the author draws on Claude Lefort's concept of indeterminacy to sketch a potentially more fruitful way than can be gleaned from the interwar German discussions of conceiving the nexus between the elitist, populist and pluralist faces of modern democracy.

The Legitimacy of Modern Democracy will be of interest to political theorists, political philosophers, intellectual historians, theoretically oriented political scientists and legal scholars working in the subfields of constitutional law and legal theory.

Pedro T. Magalhães has a PhD in Political Science awarded by NOVA University Lisbon, where he taught as a Guest Assistant Professor until 2018. He is currently a post-doctoral researcher at the Academy of Finland funded Centre of Excellence in Law, Identity and the European Narratives (Eurostorie), hosted by the Centre for European Studies at the University of Helsinki. His main research interests are in the fields of democratic theory, modern political ideologies and twentieth-century intellectual history. 


\section{Routledge Innovations in Political Theory}

\section{Reconstructing Nonviolence}

A New Theory and Practice for a Post-Secular Society

Roberto Baldoli

Rethinking Positive and Negative Liberty

Maria Dimova-Cookson

The Problem of Value Pluralism

Isaiah Berlin and Beyond

George Crowder

\section{On Biopolitics}

An Inquiry into Nature and Language

Marco Piasentier

Democracy, the Courts, and the Liberal State

A Comparative Analysis of American and German Constitutionalism David Miles

\section{Legislative Deliberative Democracy}

Debating Acts Restricting Freedom of Speech during War Avichai Levit

\section{The Legitimacy of Modern Democracy}

A Study on the Political Thought of Max Weber, Carl Schmitt and Hans Kelsen

Pedro T. Magalhães

For more information about this series, please visit: https://www.routledge. com/Routledge-Innovations-in-Political-Theory/book-series/IPT 


\section{The Legitimacy of Modern Democracy}

A Study on the Political Thought of Max Weber, Carl Schmitt and Hans Kelsen

Pedro T. Magalhães 
First published 2021

by Routledge

52 Vanderbilt Avenue, New York, NY 10017

and by Routledge

2 Park Square, Milton Park, Abingdon, Oxon, OX14 4RN

Routledge is an imprint of the Taylor \& Francis Group, an informa business

(C) 2021 Taylor \& Francis

The right of Pedro T. Magalhães to be identified as author of this work has been asserted by him in accordance with sections 77 and 78 of the Copyright, Designs and Patents Act 1988.

The Open Access version of this book, available at www.taylorfrancis.com, has been made available under a Creative Commons Attribution-Non Commercial-No Derivatives 4.0 license.

Trademark notice: Product or corporate names may be trademarks or registered trademarks, and are used only for identification and explanation without intent to infringe.

Library of Congress Cataloging-in-Publication Data

Names: Magalhães, Pedro, 1970- author.

Title: The legitimacy of modern democracy : a study on the political thought of Max Weber, Carl Schmitt and Hans Kelsen / Pedro T. Magalhães.

Description: New York : Routledge, [2021] | Series: Routledge innovations in political theory; Voume 89| Includes bibliographical references and index.

Identifiers: LCCN 2020036996 (print) |

LCCN 2020036997 (ebook) | ISBN 9781138068889 (hardback) | ISBN 9781315157566 (ebook) | ISBN 9781351654012 (adobe pdf)| ISBN 9781351653992 (mobi) | ISBN 9781351654005 (epub)

Subjects: LCSH: Democracy. | Weber, Max, 1864-1920-

Political and social views. | Schmitt, Carl, 1888-1985-Political and social views. | Kelsen, Hans, 1881-1973-Political and social views.

Classification: LCC JC423 .M1236 2021 (print)|

LCC JC423 (ebook) | DDC 321.8- dc23

LC record available at https://lccn.loc.gov/2020036996

LC ebook record available at https://lccn.loc.gov/2020036997

ISBN: 978-1-138-06888-9 (hbk)

ISBN: 978-1-315-15756-6 (ebk)

DOI: $10.4324 / 9781315157566$

Typeset in Times New Roman by codeMantra 


\section{In memoriam}

Idilásio da Silva Tereso (1933-2020) 

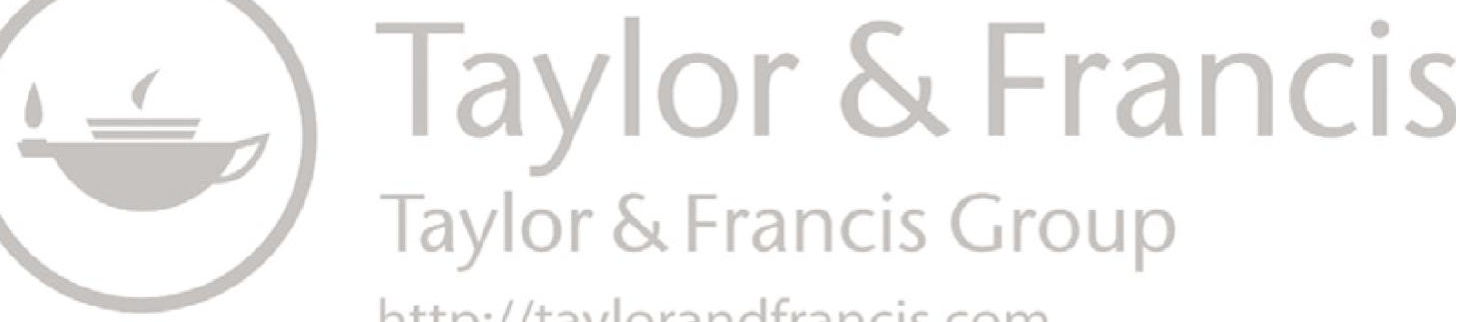

http://taylorandfrancis.com 


\section{Contents}

Acknowledgements - xi

Introduction

1 Max Weber's Diagnosis of Modernity and the Ambivalence of Modern Democracy 21

2 The Neo-Authoritarian Populism of Carl Schmitt 65

3 Science, Relativism and Pluralism: Hans Kelsen's Conception of Modern Democracy

Elitism, Populism and Pluralism: A Conclusion 

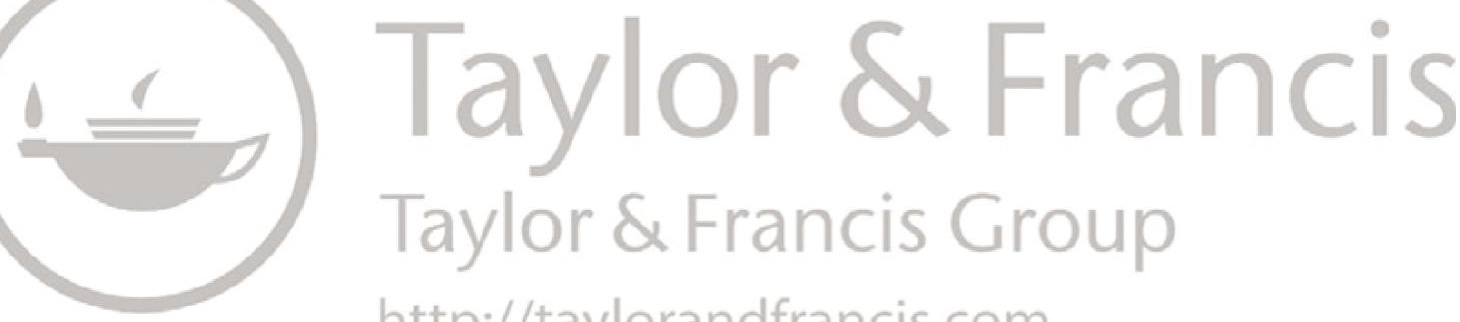

http://taylorandfrancis.com 


\section{Acknowledgements}

During the decade that has passed since I decided to embark on this research project on the legitimacy of modern democracy and its conclusion, I have accumulated a debt of gratitude to more individuals and institutions than I can name. But I will do my best here not to forget anyone. First and foremost, I would like to thank Pedro Tavares de Almeida and Diogo Pires Aurélio, supervisors of the doctoral dissertation from which this book emerged. Without their support and guidance, I would not have been able to bring this project to completion. I am also indebted to Martin A. Ruehl, who gave me the opportunity to spend a semester as a visiting PhD student at the Department of German and Dutch of the University of Cambridge, in the academic year 2013-2014. His suggestions and constructive criticisms, during and after that research stay, were invaluable. My work on this book was completed while I was a member of the Academy of Finland funded Centre of Excellence in Law, Identity and the European Narratives (Eurostorie), hosted by the Centre for European Studies at the University of Helsinki, where I am currently based as a post-doctoral researcher. The advice and stimuli from all the unbelievably kind and generous people of Eurostorie influenced the final version of this volume in more ways than I could have at first imagined, but a special word of appreciation goes to the intellectual companionship of the three scholars I work most closely with there: Pamela Slotte, Timo Miettinen and Tuukka Brunila. Furthermore, I would also like to thank my students at NOVA University of Lisbon and at the University of Helsinki, with a special mention to those who attended the master's courses on 'Political Elites' (Lisbon, 2018) and on 'Populism in Europe and Beyond' (Helsinki, 2020), the last of which I taught together with Tuukka Brunila. If perchance any of the students who attended these courses happens to read this book, they will surely find traces in it of the lively discussions we had during the seminar sessions, where many of my ideas were either tested for the first time or rehearsed again before an attentive and engaging audience. Last but not least, I am also grateful to all the colleaguesfar too many to mention without unjustly forgetting someone-who were kind enough to read and comment on my work in various academic venues during the last ten years. Paul Behne checked my translations from 
the German and Heta Björklund prepared the index-I thank them both for their efficient work. Finally, I would like to thank Natalja Mortensen, senior editor of political science at Routledge, for her patience with my inability to keep deadlines. Any errors, omissions and imperfections in this book are, of course, the author's sole responsibility.

For financial support, I am grateful to the Portuguese Foundation for Science and Technology $(F C T)$, which provided the doctoral grant (ref. SFRH/BD/79450/2011) that allowed me to begin the project in January 2012 and supported me until the completion of the dissertation in February 2016. As of August 2018, I have benefited from the financial support of the Academy of Finland funded Centre of Excellence in Law, Identity and the European Narratives (funding decision no. 312430).

This book is dedicated, with love, to Carolina and our new-born daughter. 


\section{Introduction}

As long as a certain form of government is taken for granted, any interest in the problem of its legitimacy is bound to come across as a matter of idle theoretical speculation, with no practical import. The most likely result, in such circumstances, is to move around in circles by emphasizing the affinities between the presumably self-evident form of government and what is assumed to be equally self-evident in other realms of human thought and action. In times of stability, there is a mutually reinforcing connection between what is taken to be politically right, morally adequate and rationally sound or reasonable. To be sure, periods of stability have been rare in the modern age and not only in the political domain strictly speaking. However, beyond the annihilation of the old political and theological authorities and the images upon which they rested, modernity also carried the promise that these could eventually be replaced by a new cohesive framework that would be more conducive to the full development of human capacities.

Democracy is an indispensable part of such a modern redemptive vision. And indeed, for a brief historical interlude at the turn from the twentieth to the twenty-first century, it might have seemed, even to sober commentators, that a certain variety of democracy had institutionally incarnated the spirit of progress, reason and common sense, and could henceforth be viewed, regardless of the empirical setbacks it might still encounter along the way, as a form of government justifiably aspiring to permanence. Some viewed the defeat of fascism in the Second World War as the decisive moment in this regard. According to this view, the Allied victory over the Axis powers constituted a veritable 'normative watershed' that "undermined the foundations of all forms of political legitimation that did not - at least verbally, at least in words - subscribe to the universalist spirit of political enlightenment' (Habermas, 2001: 46). ${ }^{1}$ This means that the alliance between the Western powers and the Soviet Union should not be treated as "unnatural," for both sides of the soon to come Cold War adhered - 'at least in words' - to the progressive spirit of the Enlightenment, and both were composed - even if arguably only nominally so — of 


\section{Introduction}

democratic regimes. However, 1945, the year which, to use Habermas's (ibid.) words, signalled 'a change in the cultural and intellectual climate that formed a necessary condition' for the triumph of democracy, is not where the narrative of democratic triumph ends. Instead, it is the collapse of the Soviet bloc in 1989 which, according to the verdict of a soon-to-be famous analyst, marks 'the end point of mankind's ideological evolution and the universalization of Western liberal democracy as the final form of human government' (Fukuyama, 1989: 4). ${ }^{2}$ The triumph of democracy in the short twentieth century meant thus more than the general acknowledgement - wholehearted or less so — of a vaguely defined and broadly understood normative spirit. Rather, it was held to be the victory of a relatively precise institutional arrangement. And in that sense, it was as much a victory of democracy as it was of liberalism.

One can interpret this triumph of liberal democracy in the late twentieth century as a process whereby the 'appraisive,' but 'essentially contested concept' (Gallie, 1955/1956: 168, 183) of democracy became less of a focus of dispute by being de-contested in a specific direction. ${ }^{3}$ This de-contestation, in my view, attains its consummate expression in the substantive claims of analytic political philosophy, a tradition founded single-handedly by John Rawls's A Theory of Justice, originally published in 1971. The result of Rawlsian philosophy is that only the institutional arrangements of political liberalism satisfy the conditions of social justice. Liberal democracy, indeed, constitutes the only political system that can be robustly justified from the perspective of a rationally oriented moral philosophy, that is, of Enlightenment social contract theory, which Rawls (1999: 10) seeks to carry 'to a higher level of abstraction.' It seems impossible, in hindsight, not to interpret Rawls's project as a manifestation of self-confident liberal democratic hegemony. After the irrationalist mythologies of fascism had been defeated, and as soon as one could be rest assured that "real socialism" constituted no match to it, liberal democracy found in Rawls the great philosophical mind that worked out its specific qualification, or de-contestation, of the concept of democracy. It did so by tying democracy firmly to the rationalist and individualist premises of Enlightenment philosophy, which at the same time were further refined and recultivated. However, by setting up as the chief task of political philosophy to discern abstract principles of justice and their hierarchy, Rawls circumscribed the limits of the possible and the thinkable for liberal democratic politics, the scope of admissible alternatives and reasonable disagreement within such a framework. To be sure, that scope is wide-ranging, as the innumerable debates generated by his work show. However, the very fact that the controversy has centred on the, according to the author's hierarchy, secondary "difference principle" and its presumably redistributive implications, rather than on the primary principle of "equal liberty," suggests that most of Rawls's critics accept the unspoken corollary of his theory of justice. More precisely, they accept that 
no self-interested, rational person would choose to live in a hypothetical society deprived of the basic legal and political institutions shared by all "actually existing" Western democracies, irrespective of how much these may vary - and, we do not claim to deny it, they do vary significantly —in the way they deal with social and economic inequalities. ${ }^{4}$

The first two decades of our century have dealt a blow to the selfconfidence of liberal democracy and its sense of moral superiority. After all, notwithstanding the successes of the so-called "third wave" of democratization in Southern and Eastern Europe and in Latin America (Huntington, 1991), the definitive victory of liberal democracy, which many had both predicted and hoped for, did not materialize. Subtle forms of 'democratic backsliding' (Bermeo, 2016) are being experienced just as novel, increasingly sophisticated varieties of authoritarian rule gain momentum all over the globe. The resurgence of nationalism threatens the cosmopolitan outlook and the universal ambitions of the liberal democratic project, casting a dark shadow over a liberal international order that perhaps never was (Barnett, 2019). In turn, the rise of populism, left and right of the political spectrum, has put the prospect of an illiberal democracy back on the agenda. Finally, the drift of neoliberalism from a moral to a purely strategic rationality (Amadae, 2015) suggests that even self-professed liberals might be willing to embrace forms of government other than the liberal democratic one.

Bleak as it may be, this panorama should not lead one to pessimism and despair. Instead, the moment should be seized to dig deeper into the problem of modern democracy and re-examine, beyond the self-satisfied confines of contemporary moral philosophy, its historical genesis, symbolic significance and political value. This is what the present book aims to achieve by reassessing the political thought of Max Weber (1864-1920), Carl Schmitt (1888-1985) and Hans Kelsen (1881-1973). These thinkers' views on democracy, however different they are from one another, do not attain the systematic clarity of Rawls's defence of liberal democratic institutions. Yet, this should not be taken as a liability or as an expression of a lack of insight and lucidity. On the contrary, their frequently blurred concepts and the difficulties these engender allow us to restore a sense of uncertainty to the analysis of democracy, which the now eroding liberal democratic consensus had inhibited - and to bring yet again to the fore the ineradicable tensions and ambivalent representations that fuel modern politics.

It is not the intention of this study to present a definitive interpretation of Weber's, Schmitt's and Kelsen's work, a task not only unconfinable to the scope of a single monograph but also beyond the capacities of a single scholar. ${ }^{5}$ We will be orientated, in the discussion of their work, by the problem of modern democracy, even if, to elucidate it properly, several incursions into other topics are unavoidable. Despite this primarily thematic orientation, however, we do not intend to offer a highly selective 


\section{Introduction}

and excessively "creative" reinterpretation of their thought, which would neglect the historical question of what they "actually meant" (Pocock, 1973). Our aim is thus to strike a balance between the perspectives of intellectual history and political theory, i.e. between an account of Weber's, Schmitt's and Kelsen's ideas on democracy and related themes as they understood them, on the one hand, and a discussion of their relevance for democratic theory today, on the other hand. Of course, the risk of such an approach is to come short on both ends, to fail to meet the exigencies of both intellectual historians and political theorists. However, this is the only approach that may lead to a contribution, if I am allowed to paraphrase an astute sociologist and make his plea-formulated almost half a century ago - mine, to a historically and philosophically reflexive science of politics (Martins, 1974: 287). Furthermore, this methodological sitting on the fence - a fence that should never have been erected in the first place, but that is another issue - also does justice to our material, for although the views on modern democracy we will delve into were written roughly one century ago, the task of discerning the meaning of the modern democratic experience still constitutes a challenge to political thought.

The book is divided into three main chapters and a conclusion. The main chapters present, analyse and critically evaluate each author's democratic thought, placing it in the broader context of their euvre and tying it to their intellectual backgrounds and major theoretical as well as political concerns. Max Weber's priority, in this account, is not merely chronological. As McCormick (2013: 55) keenly puts it, Weber's work has cast 'a long and deep shadow' over a whole generation of thinkers who came after him. He outlined the fundamental problematic of understanding the nature of modern society and its characteristic forms of rule, their historical genesis and future prospects. Chapter 1 seeks, thus, to situate Weber's dispersed and unsystematic thoughts on modern democracy in the larger scope of his work. It does so chiefly by (1) considering his narrative of modernity and the conception of history it stems from; (2) analysing his concepts of power, domination and authority, especially with regard to the ideal types of legitimate rule developed in his sociological work; (3) assessing his positions in the context of the democratic reconstruction of German politics in the aftermath of the First World War. Weber's relevance, I argue, derives from the fact that he was one of the first champions of modern democracy who recognized the paradoxes and ambiguities which lie at the core of the modern democratic project. Even if, in hindsight, his elitist account appears problematic and insufficient in many respects, Weber provides fundamental elements for a discussion of democratic legitimacy that takes the ambivalence of the modern age seriously.

Chapter 2 interprets Carl Schmitt's interwar political thought as a form of neo-authoritarian populism. This interpretation is laid out in 
three steps. First, I review some of the works Schmitt wrote before and during the First World War to delineate his intellectual position at the onset of Weimar's democratic experience. Second, I reconstruct his neoauthoritarian vision of modern politics based on an analysis of two important works from the early 1920s, Dictatorship and Political Theology, paying close attention to his explicit and implicit demarcation from Max Weber's and Hans Kelsen's ideas. Third, I examine Schmitt's conception of the people as the immanent source of political authority and legitimacy in the modern age, underscoring both its reliance on a vague notion of substantial homogeneity and its subordination to his neo-authoritarian decisionism. Throughout the chapter, I will also show how Schmitt uses a variety of other thinkers, from diverse political leanings and philosophical persuasions, as masks to convey his own ideas in a peculiarly underhanded way. I conclude that Schmitt's neo-authoritarian populism fails to do justice to the singularities and complexities of modern democracy.

Chapter 3 contains an exposition and a critical assessment of Hans Kelsen's conception of modern democracy, which takes into account Kelsen's theory of law and legal science - undoubtedly the author's chief intellectual project - but does not reduce the former to the latter. In doing so, it establishes relevant comparisons and contrasts to the intellectual and political orientations of both Max Weber and Carl Schmitt. The chapter is structured in three main parts. The first section offers a sketch of Kelsen's pure theory of law, probing into its philosophical underpinnings and crucial conceptual and methodological distinctions. In a second moment, the focus shifts to Kelsen's theory and defence of parliamentary democracy, in regard to which its pluralistic consequences are underscored. Third, the chapter presents a reflection on the tensions that inhabit Kelsen's scientistic worldview, examining the claim that relativism constitutes the link that connects his legal science to his democratic thought. We conclude by suggesting the Lefortian notion of indeterminacy as a fruitful substitute for relativism to think about democratic pluralism beyond Kelsen.

Finally, the conclusion draws on the analysis of Weber's, Schmitt's and Kelsen's thinking on modern democracy to assess the origins, insights and limits of the three chief theoretical models that political science developed to interpret democracy in the second half of the twentieth century: elitism, populism and pluralism. It shows that contemporary elitist, populist and pluralist accounts of democracy owe, in diverse and sometimes complicated ways, an often unacknowledged intellectual debt to the interwar era, German-speaking, scholarly and political controversies on the nature and legitimacy of modern democracy. In its final section, the conclusion forwards Claude Lefort's conception of modern democracy's radical indeterminacy to outline a more fertile way than that which can be gleaned from the three thinkers of conceiving the nexus between the elitist, populist and pluralist faces of democracy. 


\section{Introduction}

\section{Legitimacy, Modernity and Democracy}

However, before proceeding to the question of how democracy read its own nature and history in German-speaking interwar Europe, some preliminary historico-conceptual reflections are in order. Let us start with the notion of legitimacy. To enquire into the legitimacy of a regime, an institution or a decision confronts us, in the final analysis, with a perennial challenge, whose earliest thematizations stretch back to the founding myths of entire civilizations. It could be argued that our concern with legitimacy stems from an instinctive, deep-seated refusal of the arbitrariness of power, whose validity cannot-indeed, must not—depend solely on the will of the rulers (Goyard-Fabre, 1990: 235). In the Western tradition, the myth of Antigone constitutes arguably the strongest expression of such a refusal. Antigone's decision to bury and mourn her brother Polynices against the express orders of King Creon, and the justification of such an act by emphasizing the precedence and superiority of divine law over earthly laws, exposes the insufficiency of power-be it de facto or de jure - as the source of its own validity, and affirms the moral duty to disobey. ${ }^{6}$ To avoid arbitrariness and ultimately disorder, political power must be made subordinate to a principle that transcends the momentary whims of office holders, be it an eternal law of nature, reason or God, the promotion of the common weal, the consent-tacit or explicit-of the ruled or the dynamic laws of history. In a broad sense, the concept of legitimacy can be said to underlie all political thought understood as a reflection on the problems of authority and order and their acceptance by those who are ruled.

However, despite these mythical origins, the widespread use of the words "legitimate" and "legitimacy" in politico-philosophical discussions goes no further back than the eighteenth century. The language of political legitimacy is thus a distinctly modern artefact. The medieval antecedents of such language are related to the process, determined by a complex variety of reasons both religious and secular, whereby canonical definitions of marriage and family acquired a tremendous political significance, as they began to be used to settle disputes over succession to royal title (McDougall, 2017: 2-8). Notions of legitimacy retained throughout medieval and early modern Europe their primary link to the sphere of family law, and political consequences were, in a way, merely superimposed upon the latter.

Quite revealingly, legitimacy, or rather légitimité, seems to have emerged as a distinctly political idea precisely when illegitimacy began to fade as a moral concern in the realm of gender and family relations, in the context of the Enlightenment. The abstract noun with a political meaning emerges only after the French Revolution, coined by reactionary thinkers in explicit opposition to the revolutionary idea of popular sovereignty. However, before the emergence of the abstract noun in 
the post-revolutionary context, there are important changes in the use of the adjective légitime in French political thought, which one must briefly take note of.

In his Six Books of the Commonwealth, originally published in 1576, Jean Bodin, one of the forerunners of the theory of monarchical absolutism, makes abundant use of the adjective légitime. Most of the times, it appears in the standard medieval context of reflections on hereditary succession (Bodin, 1993: 75, 144, 444). However, in a decisive move, Bodin (1993: 521) reinterprets Aristotle's (1885: 79-80) three true or correct (orthoi) forms of government as the 'three legitimate Republics. ${ }^{7}$ Légitime acquires thus the extended meaning of something that is true or correct in the domain of political ideas and institutions. ${ }^{8}$ Almost two centuries later, Jean-Jacques Rousseau emerged, effectively, as 'the modern founder' of the distinction between 'legitimate and illegitimate regimes' (Richter, 1995: 84). In The Social Contract (1762), both légitime and illégitime, though the former much more frequently than the latter, appear unambiguously in the sense that modern political theory ascribes to the terms, without hinting to notions of heredity and family law. Indeed, the adjective figures prominently in that work's most famous passage:

Man is born free; and everywhere he is in chains... How did this change come about? I do not know. What can make it legitimate? That question I think I can answer.

(Rousseau, 1797: 3, as translated by Richter, 1995: 78) ${ }^{9}$

Legitimate refers here to the foundational principles which sustain political authority and justify the leap from the state of nature to society. Bodin, albeit an advocate of royal absolutism, had nevertheless recognized, under the influence of Aristotle, alternative and equally legitimate- though inferior - forms of rule. For a proponent of popular sovereignty like Rousseau, however, there is no alternative when it comes to the foundation of political forms: The people must be the author of the laws to which it submits, regardless of the concrete form of government, which may be monarchic, aristocratic or democratic. In this sense, 'all legitimate government is republican,' whereby a republic means, for Rousseau (1797: 84), not a particular state form, but all government guided by the law, by the general will. Therefore, even if Rousseau never employed the noun légitimité, the abstract notion of legitimacy as it is understood by modern political theory, referring to the ultimate justification of authority, to the grounds of the validity of political rule, is distinctly conveyed by his use of the adjective légitime - a use which, furthermore, undoubtedly forwards a democratic understanding of legitimacy.

The first explicit formulations of the abstract noun légitimité occurred, however, in the context of the doctrinal reaction against the French 


\section{Introduction}

Revolution, put forth by authors such as Joseph de Maistre and Louis de Bonald. By the time Rousseau transferred the adjective légitime to the vocabulary of law and politics, illegitimacy was beginning to fade as a moral concern. As Gerber (2005) shows, the intellectual environment of the Enlightenment produced changes in legal culture which resulted in the progressive de-stigmatization of illegitimate offspring, while other concerns, notably with child welfare, gained ground. ${ }^{10}$ In contradistinction, the counterrevolutionary thinkers sought to preserve the link between political legitimacy and heredity, between the domains of politics and traditional kinship. Bonald (1817: 170) put it most forcefully when he stated that 'the first legitimate and natural law of the political state is the legitimacy of succession." ${ }^{11}$ In other words, for a regime to be politically legitimate, it had to rest on hereditary legitimacy. Since for Bonald-perhaps following Aristotle more closely than most modern interpreters - political society derived from domestic society, the two dimensions of legitimacy are inseparable and in the final analysis, it was the latter that grounded the former. Therefore, he equated democracy and divorce. In his view, both allowed the weakest links of society-the people on the one hand, wife and children on the other hand-to rise against legitimately established authority. ${ }^{12}$

In contrast to Rousseau, who conflated legitimacy with the law as an expression of the people's general will, the French reactionaries appear also to have been the first to formulate an explicit opposition between legality and legitimacy, and to insist that the latter meant more than the former. In Bonald's (1817: 170) incisive words, while '[t]he merely legal state is established by the will of man alone..., [t] he legitimate state is in conformity with the will of nature or, rather, of its Author.' ${ }^{\prime 3}$ Democracy, thus, might emerge from a cataclysmic event as a new legality, out of the sheer will of man, but it will never be stamped with the 'seal of legitimacy' (Maistre, 1819: 242), for, more than conformity to man-made law, that requires divine sanction. According to these thinkers, dynastic legitimacy is, in the last analysis, the undisputable revelation of a divine will. God is the ultimate source of political legitimacy, which is conferred upon a monarch and his lineage by God's representative on earth, the Pope. The authority of the monarch is absolute 'within his circle of legitimacy' (Maistre, 1819: 221), but given that his power is derived from God, he is subject to His laws and, more importantly, to the spiritual authority of His church. ${ }^{14}$

Hence, the idea of political legitimacy originated in the context of a bitter ideological struggle, which opposed two mutually exclusive foundations of authority: God and the people. The notion was first developed by the intellectual father of modern democratic thought and later reinterpreted by the staunchest adversaries of democracy, the partisans of dynastic legitimacy. Between Rousseau and Bonald or Maistre, of course, there was enough room for more moderate readings of both principles. 
Not every republican was an uncompromising Jacobin, nor every monarchist a reactionary ultra. ${ }^{15}$ In any case, the order one uses to introduce and position the two alternative poles of the dichotomy relative to one another is far from being irrelevant. If God comes first, then the people emerge as the entity which takes God's place and appropriates His qualities. This would lead us to the approach of political theology, which we shall discuss in more detail in the chapter on Carl Schmitt. Here it suffices to say that, from such a perspective, the modern theory of the state, and particularly the concept of sovereignty, appears essentially as secularized theology. Bertrand de Jouvenel (1972: 78) follows this line of reasoning, when he speaks of a striking parallelism between Rousseauian popular sovereignty and the medieval theory of divine sovereignty, an intuition upon which Riley (1988) also elaborates. The priority of the divinechronological and logical-also goes a long way towards explaining the structural homologies between Rousseau's and Maistre's concepts of sovereignty. Since Rousseau, according to this view, did little more than to secularize the abstract concept to which sovereignty ultimately refers, the basic characteristics of the latter, which had been theorized by royal absolutism leaning on medieval theology-its absolute, indivisible and inalienable nature-remained unchanged, and Maistre's move against Rousseau amounted merely to a re-inscription of the concept of sovereignty in the orbit of Christian theology (Rabier, 2013). Within the 'theologico-political labyrinth,' as Lefort (1988: 254) keenly observes, 'any move towards immanence is also a move towards transcendence.' In that sense, Rousseau's quest to justify political authority on immanent grounds rested on a transcendent concept - the people with its general will - which was as abstract, metaphysical, intrinsically benign and allpowerful as that which it aimed to replace. The conclusion that popular sovereignty constitutes an inverted offshoot of divine sovereignty is, according to this perspective, scarcely avoidable.

But a different story can be told from the opposite angle. Holmes (1982: 167) has argued it quite persuasively in his interpretation of the Catholic defence of dynastic legitimacy as 'a case of the Right imitating the Left.' The focal point, in this case, is the Revolution of 1789 and its unprecedented attempt to ground legitimate power on a popular basis. Obviously, there were no reactionaries before the Revolution, nor was there a need to insist on dynastic legitimacy as a political ideology. Hereditary succession to the throne derived its self-evidence from custom and the Canon law of marriage. However, such traditional 'markers of certainty' (Lefort, 1988: 179) were shattered by the irreversible opening of the question of the foundations of political authority occasioned by the Revolution. Legitimism would not have emerged as a political ideology in the beginning of the nineteenth century, if the Revolution had not radically challenged the theologico-political nexus of Christian Europe, if it had not established the perception of a break, which forced the advocates 


\section{0}

of the old order to recast themselves in the image of the new order. In the reactionary theory of the state, as Holmes (1982: 166) aptly remarks, 'the concept of Legitimacy took over the uncompromising stridency and world-rescuing pretensions of the ideology it opposed.' Here, it is not the people that appears as a counterfeit God, but rather divine-right legitimacy which emerges as a counter-ideology. According to this view, progressive thought 'dictates the tempo and the form of the battle' to the conservative thinkers (Mannheim, 1954: 208).

The Great Revolution of 1789 haunted the minds of its contemporaries like a truly original event, i.e. one which seemed to define all that was to come, without having a discernible past which could have rendered its own appearance intelligible. Perhaps the most far-reaching symbolic expression of the originality of the event was the replacement of the Gregorian calendar by a new revolutionary or republican calendar, which signalled that something had taken place, whose meaning for world history was thought to surpass no less than that of the birth of Christ. ${ }^{16}$ Time itself should from now on, according to the more radical revolutionaries, refer to such a foundational event, and since the event was political in nature, it also meant, as Hegel (1894: 157) denounced in 1817, that legitimate power and the political order were now supposed to stand 'on a ground of their own.'

The hypnotic grasp of the Revolution on the minds of the intellectual elite - progressives and reactionaries alike — was, however, not restricted to those who witnessed the key meaningful event in first hand. Across the Channel, Edmund Burke (1987) reacted early on with a seminal intellectual attack against the Revolution. Across the Rhine, where we now turn our attention to, the philosophical currents of German idealism split on the issue, but the conservative ranks were much more densely populated than the revolutionary ones. Indeed, the war against the Napoleonic armies $^{17}$ and the non-revolutionary state- and nation-building processes during the nineteenth century turned Germany into arguably the most fertile ground in Europe for the development of conservative political ideas. As Mannheim (1986: 47) put it, 'Germany achieved for the ideology of conservatism what France did for progressive Enlightenmentshe worked it out most fully to its logical conclusions.'

One of the ideas thought through by German conservatives - and one which Mannheim, in his influential studies, hardly ever mentions - was precisely that of hereditary or dynastic legitimacy. According to conservatives schooled in the philosophical tradition of German idealism, the significance of the idea of a dynasty does not reside in its conformity to family law and custom, but, rather, in its capacity to symbolize the permanence of political unity across the generations. The king's natural body incorporates the mystical idea of the unity of the political community, and it thus acquires a dual nature which conjoins the earthly and the divine (Kantorowicz, 1957). However, for the idea of political 
unity to actually transcend the finitude of the king's body natural, the contribution of heredity is crucial. In his 'Aphorismen über den Staat,' probably written between 1808 and 1814, Friedrich Schleiermacher (1845: 225-226) argues that an elected monarch would be incapable of fulfilling such a symbolic function. A true monarch must elevate the idea of political unity above the turbulence of its historical becoming, and that, according to Schleiermacher, required a hereditary king, a dynasty. The wish to extract the person of the monarch from the contingencies of historical reality, and to project this person to a superior symbolic realm, leads the German philosopher to consider the advantages of conceding the throne to foreign dynasties, for these, more distant to native historical events than "national" dynasties, would be able to incarnate the idea of political unity in a purer fashion. Still, not even the most illustrious of foreign lineages would be in the position to ditch its connection to history altogether. Every monarch, every dynasty carries with itself, to quote an early essay by Eric Voegelin (2003: 246), 'a mortal remainder,' which puts a limit to the process of symbolization. In the final analysis, the monarch is but a representative, and representation does not - and cannot-fill the gap between idea and symbol.

In actual historical fact, the gap between the idea of political unity and its monarchical symbolization widened, rather than closed, throughout the nineteenth century. Indeed, with the spread of revolutionary doctrines, the correspondence between both was increasingly challenged all over the European continent. Mid-century constitutional monarchy, where an assembly elected through limited suffrage intervened between the monarch and the symbolization of political unity, thus allowing for a minimal degree of citizen participation in the process, emerged in such context as the haven of bourgeois security. Limiting the powers of the dynastic monarch without fully accepting the principle of popular sovereignty, it embodied the precarious balance of bourgeois liberalism. However, as of 1848, the year of revolutions in Europe, the sense of security gradually gave way, within bourgeois ranks, to one of anxiety, which peaked in the early decades of the twentieth century and, especially, after the First World War (Maier, 1988: 22-39). Anxiety, one can argue, travelled from the expropriated and resentful French noblemen after the Revolution to ordinary bourgeois across the continent in the final decades of the nineteenth century.

This emphasis on a pan-European sense of bourgeois class anxiety calls for a critical perspective on certain theses of national-historical exceptionalism that gained currency after the Second World War. In particular, the thesis of a German Sonderweg, of an exceptional-and exceptionally anomalous - German route to modernity, which would ultimately explain what Meinecke labelled The German Catastrophe (1946), must be subjected to critical scrutiny. ${ }^{18}$ According to the Sonderweg thesis, the norm from which modern German history deviates, a norm 


\section{Introduction}

which conflates descriptive and moral aspects, is the "Western"-British, French and North American-experience of political, economic, social and cultural development in the wake of a successful bourgeois revolution. The absence of such a revolution in the German territories, epitomized by the failure of the national and liberal movement in 1848-1849, stood thus at the origin of a causal chain which, by leaving the political destiny of the nation in the hands of the traditional elites of the "backward" Prussian state, would tragically culminate in Hitler.

Of course, the idea of a peculiar German way in comparison to "the West" was first developed in markedly positive and self-congratulatory terms. Already in the first half of the nineteenth century, the German national movement, shaped by the experience of war against Napoleonic France and despite the avowedly revolutionary aspirations of some of its sectors, largely perceived itself as an alternative to the perhaps too radical ideas of the French Revolution. After unification under Bismarck, the intellectual elite of the Kaiserreich spent a considerable amount of energy praising both the uniqueness and the supremacy of Wilhelmine imperial institutions, emphasizing an allegedly virtuous complementarity between the monarchy, the army, the bureaucracy and the university, and insisting on the supposedly fruitful synergies ensuing from a purportedly frictionless alliance between old agrarian and new industrial elites. At the ideological level, this leads to the construction of an opposition between, on the one hand, the "spiritual" and "organic" values of German institutions and, on the other hand, the "materialism" and "mechanicism" of "the West," between German Kultur and Western Zivilisation (Faulenbach, 1980). This appraisive reading of German exceptionalism peaked in the nationalist intoxication of August 1914. Indeed, in the nationalist fervour at the beginning of the Great War, the "ideas of 1914," summed up in the formula of duty, order and justice (Pflicht, Ordnung, Gerechtigkeit), were even explicitly forwarded as an alternative to the French revolutionary triad of liberté, égalité et fraternité (Kjellén, 1915). ${ }^{19}$

In post-1945 Germany, the evaluation of historical exceptionalism was reversed. Deviation from the Western norm was reinterpreted, if not as an outright aberration, then at least as a failure to attain a desirable standard of political and cultural development. Antecedents of such an inversion, as we shall point out, can be found in Weber's political writings from the late 1910s, but only after the Second World War could it be established as a predominant interpretation. With the Third Reich viewed as the tragic outcome of modern German history, this critical reading of exceptionalism searches for the root causes of Nazism in the alleged singularity of Germany's trajectory to the modern world. The failure to consolidate liberal democracy in the interwar period is thus brought back to the absence of a successful bourgeois revolution in the middle of the nineteenth century. And there, too, lies the root of the malign disjuncture between, on the one hand, intense industrial development and, 
on the other hand, paralysis in the realm of political institutions and cultural values. According to this perspective, the German bourgeoisie was content to gain a prominent position in the economic life of the nation, refusing - or not needing - to challenge either the traditional elites' hold on political power or their cultural hegemony. In contrast to the broadbased coalitions-involving, as allies of the emancipated bourgeoisie, industrial workers, peasants and urban craftsmen - that marked the liberal democratic dynamics in "the West," the German bourgeoisie did not come of age and, as a consequence, was doomed to a conciliatory course of action that led to its feudalization. Hence, the absence of a bourgeois revolution in Germany left a conservative and authoritarian imprint on the country's pathway to modernity. ${ }^{20}$

Notwithstanding the justified methodological, theoretical and politicopedagogical reasons to insist on the concept, if not perhaps on the rather misleading word, of a negative German Sonderweg, such a narrative encounters its own impasses. On the methodological side, the post-war generation of historians in the Federal Republic departed from Ranke's (2011) nineteenth-century historiographical paradigm, whose emphasis on concrete understanding (Verstehen) leaned towards the naturalization of events, the conflation of positivity and normativity - of what was and what ought to have been - and thus did not allow for a critical perspective on the past. The need for such a critical standpoint, in turn, was closely linked to the concerns of the post-war era, pertaining to the role of memory politics in the slow and painful, but necessary, process of overcoming a traumatic national history (Vergangenheitsbewältigung). Yet, the negative Sonderweg interpretation, too, incurs in a problematic confusion of descriptive and value-laden judgements. To begin with, it raises the Anglo-American and French revolutionary experiences, irrespective of the huge differences between them, ${ }^{21}$ to the status of ideal normative models of political development, in comparison to which Germany is found wanting. In truth, however, the heroic narrative of bourgeois emancipation in "the West," which the Sonderweg interpretation presupposes, is a myth scarcely sustained by the historical record, and no serious historian of the Atlantic revolutions would subscribe to it without significant reservations and qualifications. Furthermore, the feudalization of the bourgeoisie, far from constituting a German singularity, was a pan-European phenomenon, which occurred with at least similar intensity in the Western parts of the continent (Mayer, 2010). The same goes for the crisis of bourgeois liberalism at the turn of the century. Although this crisis was surely not as profound in Britain or even in France as it was in Weimar Germany, its wide European breadth renders the unidirectional causal chain forwarded by the critical Sonderweg thesis-from the rise of the bourgeoisie through the triumph of political liberalism, as expressed in the establishment of parliamentary rule, to democracyquite implausible. Indeed, the thesis that the principles of liberalism and 


\section{Introduction}

parliamentarism, on the one hand, and those of democracy, on the other hand, are in an intrinsically tensional relationship to each other was glossed upon, in the context of bourgeois class anxiety, all over the continent, even if, as one shall see in this book's chapter on Schmitt, it was pushed to unforeseen extremes in interwar Germany.

As Blackbourn and Eley (1984: 1-35) argue in their insightful critique of the Sonderweg thesis, the German bourgeoisie, though not the chief political protagonist, did appear as the main social actor in the nineteenth century. It triggered and led extensive social and cultural change without adopting a distinctly liberal agenda or emerging in the political arena as an independent force. What is more, even when it insisted, more or less successfully, on liberal political reforms, the bourgeoisie's horizon was that of a parliamentarization, rather than a full-fledged democratization, of the imperial regime, given the fears activated by the growth of the labour movement and its rapid development into a mass political organization. ${ }^{22}$ In criticizing the Sonderweg thesis, Blackbourn and Eley (1984: 33) were 'try[ing] to restore a sense of contingency to modern German history' and to rescue it 'from the tyranny of hindsight,' an aim which is also ours. By refusing 'the tyranny of hindsight,' we intend to bring out the European dimension of the German-speaking interwar debates on modern democracy, which were based upon interpretations of the meaning of a common nineteenth-century European historical trajectory - thus discarding the odd variety of methodological nationalism that the critical inversion of German historical exceptionality unwittingly imposed. Furthermore, by looking beyond the hindsight of the "German catastrophe," one seeks to restore, and to elucidate, the specific historical retrospection of the early twentieth century, in what it implies for the present-day task of discerning the meanings and prospects of modern democracy. What ensues from such a perspective is not a tale of singularity, and much less one of intellectual pathology, but rather an account that stresses the variety of interpretations of modern democratic developments that German-speaking thinkers advanced before the rise of Nazism.

Lastly, to reject a story of singularity does not imply neglecting the peculiarities of modern German history that constitute the immediate context for the forthcoming discussion. In the early decades of the twentieth century, the German bourgeoisie, like its counterparts in the supposedly more advanced West, developed the diffuse yet indelible selfinterpretation of being under siege by the rise of mass politics and the challenge of the labour movement. However, to the condition of a panEuropean crisis of bourgeois liberalism, which stretched eastwards of Germany and south-westwards of France to the continent's peripheries, late modern Germany adds a few distinctive features, which might help explain why it has emerged as a focal point of reflection on the problem of democratic legitimacy. In contrast to post-revolutionary France, 
Germany appeared not as an instance of clear-cut oppositions between old and new, but rather as a case of tensional cohabitation of old legacies with the latest social, political and cultural developments. On the one hand, monarchic authority in Germany lasted well into the twentieth century without extensive constitutional reforms, before it collapsed with the military defeat in the First World War. While this could be taken as a sign of "backwardness," the Weimar Republic, on the other hand, harboured a great number of innovative developments, which anticipated later stages of political experience in Western Europe. For the first time in European history, a liberal democratic regime was made to rest on a political compromise led by a working-class party. Second, never and nowhere before in Europe had the relationship between industrial employers and workers acquired such a comprehensive institutional framework as that which resulted from the Stinnes-Legien agreement of 1918. Third, also for the first time in European history, the welfare state was inscribed in a constitution, immediately facing the predicaments of implementation in an adverse economic climate. And if one includes, as one should - without, however, denying its own peculiarities - the Austrian successor state to the multinational Habsburg Empire in the broader German experience, a court dedicated exclusively to the review of the constitutionality of laws and administrative acts appeared in the European legal and political panorama for the first time.

This tension between the protracted survival of old legacies and the rise of the newest features of modern life has been duly captured by the more illuminating historical interpretations of Weimar Germany. Peukert's (1991) concept of a 'crisis of classical modernity' underscores the circumstance that, in Weimar, the modern age could not anymore be viewed as a promise or a threat, which one might either eagerly await for or bitterly combat. Rather, it had to be understood as a set of complex, ambiguous and trying realities. As this historian brilliantly shows, during this decade and a half of German history, there was virtually no cutting-edge idea that was not formulated, or even tentatively implemented, in the fields of science and technology, artistic creation and intellectual production. At the same time, however, in addition to raising violent reactions, this rampant flourishing of novelty contained its own symptoms of crisis and stalemate. ${ }^{23}$ Gay (2001), for his part, in a stimulating parallel reading first published in 1968 of Weimar culture and politics, insists on the stark contrast between the largely successful resistance of the old imperial strongholds - the army, the bureaucracy and the universities - to 'outsiders' and the hegemony of these 'outsiders'-i.e. Jews and socialists - in the arts and in the new media landscape, made possible by an unprecedented democratization of the public cultural spaces. With these peculiarities in mind, as well as their insertion into the broader European context of bourgeois crisis, one can now move on to the analysis of Max Weber's views on legitimacy, modernity and democracy. 


\section{Introduction}

\section{Notes}

1 Emphasis in the original.

2 Emphasis added.

3 For an excellent intellectual historical account that illuminates twentiethcentury European political thought as a contest over the meaning of democracy, see Müller (2011).

4 Interestingly, in the introduction to the paperback edition of Political Liberalism, Rawls (2005: 1xii, n. 55) mentions Carl Schmitt as a paramount example of the intellectuals who, in Weimar Germany, 'no longer believed a decent liberal parliamentary regime was possible,' and whose 'underlying attitudes' reflected such disbelief. In Schmitt's case, however, as I will show, it is not so much disillusioned disbelief, but rather the belief in an altogether different conception of democracy, one that eschews liberalism and parliamentarism altogether, which nurtures the author's political outlook.

5 It is regrettable, in this regard, that Kelsen has not yet found a biographer who would present his life and work with the critical insight and mastery of the materials that Radkau (2013) and Mehring (2009) display in their biographies of, respectively, Weber and Schmitt.

6 For an overview of Antigone's legacy in Western culture, see Steiner (1996). Butler (2000) offers a thought-provoking feminist critique of the myth and its underlying assumptions.

7 Unless otherwise noted, all translations in this book are my own. In the case of longer passages, the original text will be quoted in an endnote, so that German and/or French-speaking readers can compare and form their own judgement on the correctness of the translation.

8 Inversely, however, the negative form illégitime is not used by Bodin to designate the Aristotelian perversion (parekbasis) of political regimes. Modifying the classical Aristotelian two-fold typology, Bodin (1993: 199ff.) distinguishes three varieties of each form of government. Rule by one, by the few or by the many may be legitimate, seigniorial or tyrannical.

9 Emphasis added.

10 Curiously, Rousseau, the first modern theorizer of political legitimacy, abandoned five of his extramarital children to the Paris foundling hospital, an act which was denounced by Voltaire in an anonymous pamphlet (Gerber, 2005: 242, n. 4).

11 '[L]a première loi légitime et naturelle de l'état politique, est la légitimité de la succession.'

12 During the monarchical restoration, Bonald (1818) fought - and succeededto expunge the right of divorce from the civil code.

13 Emphasis mine: 'L'état légitime est conforme à la volonté de la nature ou plutôt de son Auteur...L'état simplement légal est établi par la seule volonté de l'homme.'

14 This may lead all too easily to the interpretation of Catholic legitimist theory as theocratic. Such an assertion, though not entirely incorrect, must be qualified. Maistre and Bonald can be called theocrats insofar, but only insofar, as they submit temporal power to the higher spiritual ends of Church authority. In strictly temporal matters, however, i.e. 'within his circle of legitimacy,' the sovereignty of the monarch is truly absolute. Temporal power and spiritual power stand side by side in the reactionary vision of authority, each claiming supremacy within their respective, unconflatable realms. Even if spiritual ends are ultimately superior to temporal ones, the former do not fully absorb the latter. These advocates of rule by the grace of God retained a dualistic conception of power that distinguishes the temporal from the spiritual-a 
peculiarity which, one might argue, sets them apart from most non-Western theocratic conceptions, as well as from the political religions of modern totalitarianism.

15 Bonald and Maistre embody the desperate, resented and vindictive reassertion of divine-right monarchy after the Revolution, while Chateaubriand and Talleyrand voice a more pragmatic and conciliatory defence of Bourbon monarchy, anticipating the moderate bourgeois spirit of the July Monarchy (see Holmes, 1982).

16 The French Republican Calendar was officially used between 1793 and 1805 .

17 In this as in so many other cases, the struggles over the qualification of the event are quite revealing. Liberal forces in the German national movement coined, at first, the expression Freiheitskrieg (war of/for freedom) to refer to the conflict with Napoleonic France, thus endowing it with a broader political purpose beyond the mere expulsion of a foreign invader. However, it was the conservative alternative Befreiungskrieg (war of liberation), emphasizing the fight against French occupation and hegemony, which prevailed in Germany both in the political and in the historiographical discourse (Büsch, 1992: 51).

18 For a helpful critical overview of the debates on the Sonderweg thesis, see Grebing (1986).

19 One must note, however, that the inspiration for these ideas came also from sources which one should not all too readily assign to unambiguously conservative and authoritarian intellectual traditions. For instance, concerning the idea of duty (Pflicht), the reference was Kant. Not without reason, therefore, Beiser (2013: 116-117) has explained the decline of neo-Kantian philosophy in the interwar period as a consequence not only of its aporias and intrinsic philosophical problems (on these, see Beiser, 2009) but also of its association with the ideology that supported the war. On the rise of neo-Kantianism to the status of quasi-official philosophical school of the Wilhelmine Kaiserreich, see Köhnke (1986). As one will see throughout this book, the ghost of neo-Kantianism hovers, although in rather different ways, over the thought of Weber, Schmitt and Kelsen.

20 In broad strokes, this is also the comparative historical narrative put forward by Moore (2003: 38), who argues that the alignment of agrarian and industrial interests 'around a program of imperialism and reaction had disastrous results for German democracy.' However, the scope of this author's approach, which casts a glance beyond Western experiences of modernization, does not make the German case appear as a pathological anomaly. On the contrary, it integrates the German experience into one of three alternative/successive trajectories to the modern world. Alongside Japan, according to Moore, Germany has followed the capitalist-reactionary route, which involves the establishment of a conservative authoritarian regime and culminates, due to strong socio-economic pressures, in a modernizing dictatorship paradoxically led by the traditional elites. Such a path differs from both the Western liberal democracies, which emerged in the wake of bourgeois revolutions, and from the communist alternative, exemplified by Russia and China, where the peasantry, rather than the bourgeoisie or the agrarian elites, appeared as the key historical actor.

21 For a philosophical interpretation of these differences, see above all Arendt (1963). Moreover, to be sure, already the conflation of the British and the American experiences is itself highly problematical.

22 For a qualified defence of the Sonderweg concept, which takes into account the criticism levelled against it, see Kocka (1988). Considered in retrospect, 
however, the products of the Sonderweg approach — broadly understood - in the field of intellectual history (Krieger, 1957; Stern, 1961; Sontheimer, 1962; Mosse, 1964) come across as particularly unfruitful and repetitive.

23 Peukert's historical account of the Weimar Republic is, by far, superior to the more recent one authored by Nolte (2006). For a helpful synthesis of the voluminous bibliography on the history of Weimar Germany, although by now perhaps already slightly outdated, see Weitz (2007: 401-404).

\section{References}

Amadae, S. M. (2015). Prisoners of Reason: Game Theory and Neoliberal Political Economy, New York: Cambridge University Press.

Arendt, H. (1963). On Revolution, New York: Viking Press.

Aristotle. (1885). Politics, trans. B. Jowett, Oxford: Clarendon Press.

Barnett, M. N. (2019). 'The End of a Liberal International Order That Never Existed,' The Global, available online at https://theglobal.blog/2019/04/16/theend-of-a-liberal-international-order-that-never-existed/ (accessed on October 4, 2019).

Beiser, F. C. (2009). 'Normativity in Neo-Kantianism: Its Rise and Fall,' International Journal of Philosophical Studies, Vol. 17, No. 1, pp. 9-27.

Beiser, F. C. (2013). 'Weimar Philosophy and the Fate of Neo-Kantianism,' in P. E. Gordon and J. P. McCormick (eds), Weimar Thought: A Contested Legacy, Princeton: Princeton University Press, pp. 115-132.

Bermeo, N. (2016). 'On Democratic Backsliding,' Journal of Democracy, Vol. 27, No. 1, pp. 5-19.

Blackbourn, D. and G. Eley (1984). The Peculiarities of German History: Bourgeois Society and Politics in Nineteenth-Century Germany, Oxford: Oxford University Press.

Bodin, J. (1993). Les six livres de la République, ed. G. Mairet, Paris: Librairie générale française.

Bonald, L. d. (1817). Pensées sur divers sujets, et discours politiques, Paris: Adrien Le Clère.

Bonald, L. d. (1818). Du divorce, 3rd ed., Paris: Adrien Le Clère.

Burke, E. (1987). Reflections on the Revolution in France, ed. J. G. A. Pocock, Indianapolis: Hackett.

Büsch, O. (1992). Handbuch der preußischen Geschichte, Vol. II, Berlin: de Gruyter.

Butler, J. (2000). Antigone's Claim: Kinship between Life and Death, New York: Columbia University Press.

Faulenbach, B. (1980). Ideologie des deutschen Weges. Die deutsche Geschichte in der Historiographie zwischen Kaiserreich und Nationalsozialismus, Munich: C. H. Beck.

Fukuyama, F. (1989). 'The End of History?', The National Interest, Vol. 16, pp. 3-18.

Gallie, W. B. (1955/1956). 'Essentially Contested Concepts,' Proceedings of the Aristotelian Society, Vol. 56, pp. 167-198.

Gay, P. (2001). Weimar Culture: The Outsider as Insider, New York: W. W. Norton \& Co. 
Gerber, M. (2005). 'Illegitimacy, Natural Law, and Legal Culture on the Eve of the French Revolution,' Proceedings of the Western Society for French History, Vol. 33, pp. 240-257.

Goyard-Fabre, S. (1990). 'La légitimité,' Revue de théologie et de philosophie, Vol. 122, pp. 235-252.

Grebing, H. (1986). Der 'deutsche Sonderweg' in Europa 1806-1945. Eine Kritik, Stuttgart: Kohlhammer.

Habermas, J. (2001). The Postnational Constellation: Political Essays, ed. M. Pensky, Cambridge: Polity.

Hegel, G. W. F. (1894). Philosophy of Mind, trans. W. Wallace, Oxford: Clarendon Press.

Holmes, S. (1982). 'Two Concepts of Legitimacy: France after the Revolution,' Political Theory, Vol. 10, No. 2, pp. 165-183.

Huntington, S. P. (1991). The Third Wave: Democratization in the Late Twentieth Century, Norman: University of Oklahoma Press.

Jouvenel, B. d. (1972). Du pouvoir, Paris: Hachette.

Kantorowicz, E. H. (1957). The King's Two Bodies: A Study in Mediaeval Political Theology, Princeton: Princeton University Press.

Kjellén, R. (1915). Die Ideen von 1914: Eine weltgeschichtliche Perspektive, Leipzig: Hirzel.

Kocka, J. (1988). 'German History before Hitler: The Debate about the German Sonderweg,' Journal of Contemporary History, Vol. 23, No. 1, pp. 3-16.

Köhnke, K. C. (1986). Entstehung und Aufstieg des Neukantianismus. Die deutsche Universitätsphilosophie zwischen Idealismus und Positivismus, Frankfurt am Main: Suhrkamp.

Krieger, L. (1957). The German Idea of Freedom: History of a Political Tradition, Boston: Beacon Press.

Lefort, C. (1988). Democracy and Political Theory, trans. D. Macey, Minneapolis: University of Minnesota Press.

Maier, C. S. (1988). Recasting Bourgeois Europe: Stabilization in France, Germany, and Italy in the Decade after World War I, 2nd ed., Princeton: Princeton University Press.

Maistre, J. d. (1819). Du Pape, Lyon: Rusand.

Mannheim, K. (1954). Ideology and Utopia: An Introduction to the Sociology of Knowledge, trans. L. Wirth and E. Shils, New York: Harcourt, Brace \& Co.

Mannheim, K. (1986). Conservatism: A Contribution to the Sociology of Knowledge, trans. D. Kettler and V. Meja, London: Routledge \& Kegan Paul.

Martins, H. (1974). 'Time and Theory in Sociology,' in J. Rex (ed.), Approaches to Sociology: An Introduction to Major Trends in British Sociology, London: Routledge, pp. 246-294.

Mayer, A. J. (2010). The Persistence of the Old Regime: Europe to the Great War, London: Verso.

McCormick, J. P. (2013). 'Legal Theory and the Weimar Crisis of Law and Social Change,' in P. E. Gordon and J. P. McCormick (eds), Weimar Thought: A Contested Legacy, Princeton: Princeton University Press, pp. 55-72.

McDougall, S. (2017). Royal Bastards: The Birth of Illegitimacy, 800-1230, Oxford: Oxford University Press.

Mehring, R. (2009). Carl Schmitt: Aufstieg und Fall, Munich: C. H. Beck. 


\section{Introduction}

Meinecke, F. (1946). Die deutsche Katastrophe. Betrachtungen und Erinnerungen, Wiesbaden: E. Brockhaus.

Moore, B. (2003). Social Origins of Dictatorship and Democracy: Lord and Peasant in the Making of the Modern World, Boston: Beacon Press.

Mosse, G. L. (1964). The Crisis of German Ideology: Intellectual Origins of the Third Reich, New York: Schocken.

Müller, J.-W. (2011). Contesting Democracy: Political Ideas in Twentieth-Century Europe, New Haven: Yale University Press.

Nolte, E. (2006). Die Weimarer Republik. Demokratie zwischen Lenin und Hitler, Munich: Herbig.

Peukert, D. J. K. (1991). The Weimar Republic: The Crisis of Classical Modernity, trans. R. Daveson, Harmondsworth: Allen Lane.

Pocock, J. G. A. (1973). 'Languages and Their Implications: The Transformation of the Study of Political Thought,' in J. G. A. Pocock, Politics, Language and Time: Essays on Political Thought and History, New York: Atheneum, pp. 3-41.

Rabier, M. (2013). 'Deus sive populus: Joseph de Maistre, Jean-Jacques Rousseau et la question de la souveraineté,' Jus Politicum, Vol. 11, pp. 1-26.

Radkau, J. (2013). Max Weber. Die Leidenschaft des Denkens, Munich: Carl Hanser.

Ranke, L. v. (2011). The Theory and Practice of History, ed. G. G. Iggers, London: Routledge.

Rawls, J. (1999). A Theory of Justice, rev. ed., Cambridge, MA: Harvard University Press.

Rawls, J. (2005). Political Liberalism, ex. ed., New York: Columbia University Press.

Richter, M. (1995). 'Rousseau and Tocqueville on Democratic Legitimacy and Illegitimacy,' in R. Wokler (ed.), Rousseau and Liberty, Manchester: Manchester University Press, pp. 70-95.

Riley, P. (1988). The General Will before Rousseau: The Transformation of the Divine into the Civil, Princeton: Princeton University Press.

Rousseau, J.-J. (1797). Du contrat social, Paris: Mourer et Pinparé.

Schleiermacher, F. (1845). Sämmtliche Werke, Vol. 8, ed. C. A Brandis, Berlin: G. Reimer.

Sontheimer, K. (1962). Antidemokratisches Denken in der Weimarer Republik. Die politischen Ideen des deutschen Nationalismus zwischen 1918 und 1933, Munich: Nymphenburger Verlagshandlung.

Steiner, G. (1996). Antigones: How the Antigone Legend Has Endured in Western Literature, Art, and Thought, New Haven: Yale University Press.

Stern, F. (1961). The Politics of Cultural Despair: A Study in the Rise of the Germanic Ideology, Berkeley: University of California Press.

Voegelin, E. (2003). Collected Works, Vol. 7 (Published Essays 1922-1928), ed. T. W. Heilke and J. v. Heyking, Columbia: University of Missouri Press.

Weitz, E. D. (2007). Weimar Germany: Promise and Tragedy, Princeton: Princeton University Press. 


\section{Max Weber's Diagnosis of Modernity and the Ambivalence of Modern Democracy}

When they hear the word "legitimacy," social and political scientists immediately think of Max Weber and the three ideal types of legitimate domination-tradition, charisma and rational legality-he developed during the 1910s, his last and most prolific decade of intellectual activity. Although the Weberian triad might by now have become obsolete for their specific purposes (Dogan, 2010), its great achievement, in the eyes of empirically oriented social scientists, was that it rested on an operative concept of legitimacy, which allowed them to circumvent the troubled, normatively loaded waters of political philosophy. Weber (1978: 953) proceeds from '[s]imple observation,' not from theoretical lucubration, to assert that legitimacy refers to the longing for validation experienced, almost like a basic physical need, by every - even if only minimally soprivileged human being. No more and no less than any petty advantage or privilege, domination (Herrschaft) seeks validation and justification, aiming to appear, both to those who dominate and, above all, to those who have to obey, as impeccably just and well deserved. In addition, the success of the rulers' claims to having their authority acknowledged by the ruled depends less on the consistency of their arguments than on their ability to foster 'the belief in legitimacy' among the relevant audience (Weber, 1978: 213). Thus, in lieu of issuing essentially contestable value judgements on the pretensions of the ruling class, the social scientist merely has to determine, first, whether a general belief in the legitimacy of the extant order exists and, second, whereupon it rests. To help answer the latter question, Weber (1978: 953) reduced 'the ultimate grounds of the validity of a domination'2 to the ideal or pure types that form his famous triad.

It is not the intention of this chapter to examine Weber's sociological definition of legitimacy and its implications. However, given the problem that concerns us here-Weber's views on modern democracy and its legitimacy - no other approach would be feasible as a starting point. In fact, Weber wrote much more extensively on legitimacy, from 
a sociological perspective, than he did on democracy. Enquiring about Weber's understanding of the legitimacy of modern democracy forces one, therefore, to bridge the gap between his sociology of domination and his political writings, where he expands on the predicaments of German democracy immediately before, during and in the aftermath of the First World War. While such an approach might at first sight seem dubious, for it reads texts of an utterly different nature - sociological studies aiming at an "objective" consideration of their subject matter, on the one hand, polemical and often passionately written political tracts, on the other hand - through the same analytic spectacles, a careful reading shows that they productively illuminate each other. Indeed, Scaff (1989: 4) is right when he argues that it is unfruitful to strictly separate Weber's science from his politics. Also, Bendix (1977: 386, 438-457), in his explication of Weberian sociology, is fully justified in his recourse to the political writings to remedy the unfinished nature of Weber's Staatssoziologie, on which the author was working at the time of his death in 1920 , even if this commentator hangs on too much to a rigid distinction between the analytic work of the sociologist and the evaluative perspective of the politically engaged citizen. ${ }^{3}$ Moreover, the problem of modern democracy requires us to bear in mind, and to elucidate, the broader intellectual horizon of Weber's auvre. From The Protestant Ethic and the Spirit of Capitalism onwards, even if this became clear to him only later on, the fundamental goal of Weber's research programme, perhaps even of his entire life-work, was to solve the riddle of modern Western singularity. Hence, all his subsequent writings, including the occasional political pieces, must be related to that chief personal, intellectual and political concern, and such a puzzle of singularity evidently transcends the domain of empirical regularities which, according to Weber, was that of sociology strictly speaking. Finally, if there is a concept that knits the different strands of Weber's work together, it is the concept of charisma. It appears prominently in Weber's comparative-historical studies of world religions, in the sociology of domination as an ideal type of legitimate rule and in his later political writings. It would be no exaggeration to say that it constitutes the key to Weber's political thought. Indeed, as we will show, the fate of politics in the modern world, as a peculiar domain of human creativity, is for Weber tied to the destiny of charismatic authority.

With these preliminary considerations in mind, the chapter is structured as follows. The first section presents Weber's sociological conception of legitimacy, the varieties of criticism it has encountered and the methodological problems it contains. Second, the chapter delineates Weber's vision of modernity, stressing the ambivalences that lie at its core. Next, it examines the relationship of such an ambiguous diagnosis of modernity with the concept of charisma as 'the specifically creative revolutionary force of history' (Weber, 1978: 1117), which is threatened by the spectre of petrification that the immanent processes of modern life-of 
bureaucratization and, more generally, rationalization - give rise to. In the fourth section, the chapter surveys how that tension plays out in Weber's political writings, where the author tackles the issue of the German transition to a modern democratic form of government. Lastly, the conclusion weighs the accomplishments and the shortcomings of Weber's conception of modern democracy.

\section{Weber's Concept of Legitimacy: Critical Perspectives and Methodological Issues}

Weber must surely have been aware of the heavy political and ideological burden attached to the word "legitimacy" since the French Revolution. However, in his writings, there is no reference-explicit or implied-to the doctrines of either Rousseau or the counterrevolutionary thinkers. In contrast to the abundant use of the adjective "legitimate" (legitim) and of the nouns "legitimacy" (Legitimität) and - though not so often-"legitimation" (Legitimation) in his sociological writings and elsewhere, the term "legitimism" (Legitimismus) as a reference to the ideology of dynastic legitimacy is almost completely absent from his vast æuvre. ${ }^{4}$

One of Weber's biographers has linked the reading of legitimacy to the author's own urge, in private and public matters alike, to justify himself and to prove that he was right (Radkau, 2013: 615-616). Be that as it may, the ground-breaking aspect in Weber's sociological approach is the way it bypasses speculative disputes on the intrinsic normative value and logical consistency of claims to legitimacy to focus on the acceptance of such claims by a relevant audience, comprising both 'positively and negatively privileged groups of human beings' (Weber, 1978: 953). However, the intellectual operations which Weber's approach to the problem of legitimacy generates should not be confounded - at least not prima faciewith a crude, naturalistic form of empiricism, which would wholly equate efficacy and validity. ${ }^{5}$ Legitimacy is not about the de facto capacity of some individuals and groups to impose their will upon others. To be sure, domination can be efficiently exercised, at least for a while, purely on a coercive basis or grounded in other-material, ideal or emotionalmotives, which somehow make the ruled momentarily accept the claims of the rulers. Yet, such motives do not by themselves render domination legitimate. More than that, as we have already pointed out, legitimacy involves a widespread belief in the validity of domination (Legitimitätsglaube) (Weber, 1978: 31-32, 213, 248).

Critiques of Weber's sociological reading of legitimacy are essentially of three kinds: moral, political/legal and methodological. The moral critique stresses the concept's normative deficit and argues that it is a major distortion of meaning to evaluate the legitimacy of a given political order, not based on its own intrinsic qualities, but indirectly through the belief of the subjects in the order's validity. Political philosophers from 
diverse intellectual traditions and ideological persuasions have made this point, emphasizing what they saw as the pernicious nihilistic, positivistic, relativistic, decisionistic and formalistic implications of Weber's approach (Strauss, 1953: 36-80; Friedrich, 1963: 186; Voegelin, 1987: 13-22; Habermas, 1988: 97-102). Legitimacy, understood as 'the belief in legitimacy' held by the subjects of rule, might at first sight seem to render the concept immediately useful for empirical research, but it does not solve the subsequent, troublesome question of discerning what should actually count as an expression of such a belief. Does belief need to be conscious and articulated in discourse or symbols? Or is a merely tacit acknowledgement of authority, inferred from a routine behaviour of compliance, enough to establish that there is a belief in the legitimacy of the existing order? Weber's sociology, and particularly the more empiricistpositivist shape it assumes in the late 1910s, opts for the second alternative. Action matters more than words or symbols, even if it appears just as a dull, repetitive behaviour-or, critics might argue, especially if it appears as a dull, repetitive, compliant behaviour. The consequence is, thus, to interpret the sheer stability of a given order as decisive evidence for a widespread belief in its legitimacy.

The political/legal critique, in essence, deplores the transformation of distinctively political or legal concepts into sociological categories. According to this viewpoint, Weber's reading of legitimacy dissolves the specificity of the problems of political legitimacy or juristic legality by applying the concept to a vague and subjective notion of order. Quite incomprehensibly from the perspective of legal and constitutional theories and their accounts of sovereignty-however different or even antagonistic these might be-Weber maintains that, from a sociological point of view, there is no 'rigid alternative between the validity and lack of validity of a given order,' and 'it is possible...for contradictory systems of order to exist at the same time,' each being valid as long as 'there is a probability that action will in fact be oriented to it' (Weber, 1978: 32). These purely subjective systems of order, whose legitimacy cum validity is contingent upon action being regularly oriented to them, have nothing to do with the concept of order as it is commonly used in political and legal theories. Hans Kelsen (1921: 111), in an essay on Weber's interpretive sociology, does not hide his bewilderment concerning the notion of tying the validity of an order to the probability of action being empirically oriented towards it - an inadmissible move, from a legal-normative perspective. From a different angle, it also comes as no surprise that Carl Schmitt (2009: 68-69) charged Weber of contributing to the technicization and economization of political concepts and modes of thought. ${ }^{6}$

Both of these critiques no doubt reveal difficulties within Weber's sociological conception of legitimacy. Nonetheless, they often emerge from, or lead to, rather misleading, one-sided depictions of the author, as either an amoral thinker fascinated with power and stability or an 
apolitical man of science keen on dissolving political concepts into scientific-technical terms. In truth, however, the shortcomings of Weber's sociological reading of legitimacy relate much more closely to the cumbersome methodological challenges the author tried to meet than to the half-finished pictures that critics and commentators frequently paint of him. In the late 1910s, Weber's sociology was breaking away from historicism in search of a more satisfactory answer to the problems of meaning (Sinn) and understanding (Verstehen) in the human sciences. His approach is interpretive (verstehend) in the sense that it posits, quite in line with the historicist tradition, meaningful social interaction to be its object of study. But he further clarifies that the meaning he is looking for is not some culturally predetermined meaning that an interpreter might all too easily - this being the chief problem with the historicist approach inspired by the philosophy of Heinrich Rickert - project upon the action under study. Weber (1978: 4) aims at the 'subjective meaning' meant by the actual participants of social interaction. The problem which immediately arises is, of course, that of inferring meaning from social reality. Mere verbal utterances of participants are insufficient for a full grasp of the meaning attached to the relevant social interaction, since participants often remain unaware of the complex range of motives that drive their own action (Weber, 1978: 10). An analysis of behaviour, on the contrary, might provide the key to a better understanding of subjective meaning, of the real intentions and beliefs of the participants. Moreover, behaviour also has the crucial benefit, from the point of view of an empirically oriented social science, of establishing an external, objective basis for validating the interpretation of subjective meaning. However, this solution to the problem of linking meaning to, or extracting meaning from, social reality leads to a dead end. In Weber's ideal-typical account of legitimate domination, as it is outlined in 'Basic Sociological Terms, ${ }^{7}$ there is, on the one side, the claim to legitimacy - on traditional, charismatic or rational-legal grounds - advanced by the political authorities and, on the other side, the obedient behaviour of the subjects. However, since the dimensions of behaviour and meaning are strictly conjoined, i.e. since knowledge of meaning can only be accessed through the external component of behaviour, belief in legitimacy connects the claim of authorities with the compliant behaviour of subjects, as Grafstein (1981: 463) aptly observes, 'more on the basis of definition than empirical discovery.' Therefore, 'it becomes difficult on methodological grounds for Weber to distinguish the case where the claim to legitimacy is made and there is political obedience from the case where there is obedience because of the claim to legitimacy' (Grafstein, 1981: 463). ${ }^{8}$ And this leads indeed to the denouement that the moral critique had identified, but not substantiated: Albeit unintentionally, and for essentially methodological reasons, Weber's sociological conception of legitimacy ends up conflating efficacy and stability with validity. 


\section{Between Liberation and Petrification: Weber's Ambivalent Narrative of Modernity}

\section{Capitalism and Western Singularity}

The Protestant Ethic and the Spirit of Capitalism, first published in an article format in 1904/1905, is the first substantive piece of research Max Weber published after recovering from the nervous breakdown which, in the late 1890s, forced him to give up on the chair in political economy (Nationalökonomie) he held in Freiburg. Like the dense methodological papers Weber wrote around that time, laying the groundwork for his understanding of social science in contrast to alternative, especially materialist and historicist, positions in the German-speaking turn of the century Methodenstreit, ${ }^{9}$ the two essays on the relationship between Protestantism and the rise of modern capitalism appeared in the Archiv für Sozialwissenschaft und Sozialpolitik shortly after Edgar Jaffé, Werner Sombart and Max Weber took joint editorial control of that journal. Their appearance in that venue evinces a perfect match with the reformulated research aims of the journal, focused on 'the revolutionary changes wrought by capitalism' in both their 'distinctive historical character' and their 'general cultural significance' (Weber, 2012: 95, 97). ${ }^{10}$ In the preliminary note to the collected writings on the sociology of religion he wrote in 1920, Weber argues - undoubtedly talking about himselfthat the scholar concerned with problems of universal history from the perspective of modern European civilization

is bound to ask himself to what combination of circumstances the fact should be attributed that in Western civilization, and in Western civilization only, cultural phenomena have appeared which (as we like to think) lie in a line of development having universal significance and value.

(Weber, 1992a: xxviii) $^{11}$

Here, unmistakably, we have a reference both to the 'distinctive historical character' of the modern West (product of a 'combination of circumstances') and to the 'general cultural significance' of the manifold changes which have had either their origins and/or their most intensive expressions there ('in a line of development having universal significance'). After briefly surveying Western singularity in other spheres (which he analyses in depth in other parts of his work), from science through music and architecture to state, politics and administration, Weber concentrates on that 'most fateful force in our modern life, capitalism.' According to Weber, capitalism should not be simply equated with a profit or moneymaking orientation, which is for sure a universal phenomenon, but 'has in itself nothing to do with capitalism' proper (Weber, 1992a: xxxi). 
What is more, and this refutes some of the cruder interpretations of his reflections on the link between Protestant asceticism and the spirit of capitalism, Weber states explicitly that he is not concerned with a wide range of undoubtedly capitalistic practices, especially of a financial nature, that antedate the age of the Reformation and, thus, can hardly be said to have been decisively shaped by it:

The capitalism of promoters, large-scale speculators, concession hunters, and much modern financial capitalism even in peace time, but, above all, the capitalism especially concerned with exploiting wars, bears this stamp even in modern Western countries... But in modern times the Occident has developed, in addition to this, a very different form of capitalism which has appeared nowhere else: the rational capitalistic organization of (formally) free labour.

(Weber, 1992a: xxxiv) $^{12}$

In this passage, Weber appears to be moving close to the Marxian perspective of a radical discontinuity in history occasioned by the separation of capital and labour (Marx, 1973: 474-489). Indeed, for Weber too, the significance of such a separation seems to be the peculiar hallmark of Western capitalism, which succeeded, like no other historical epoch before, in dissolving the reign of kinship ties over economic and political life. The tendency towards a methodical, rational organization of labour is the specific aspect of modern capitalism, which Weber sees emerging as an unintended consequence of the ethical teachings of certain Protestant denominations (especially Calvinism), or if one phrases it in more cautious terms, better attuned to the spirit of Weber's essays, which arose against the background of laymen's concerns for salvation in the beyond, whose intensity is very difficult for us - and for us even more so than for Weber - to imagine. But before labour could be subjected to thorough rational organization, its separation from capital must have been already generally recognized. This, in turn, is a process which, far from having anything to do with the ethics of Protestantism, is explained by two interconnected developments, whose roots stretch further back in time. These are, on the one hand, 'the separation of business from the household' and, on the other hand, the "legal separation of corporate from personal property' that alone can consolidate the former (Weber, 1992a: xxxv). Eventually, however, the separation of capital and labour, together with the rational organization of labour by the owners of capital and the specialized staff at their service, gives rise to the antagonism between the bourgeoisie and the proletariat which dominates modern Western politics (Weber, 1992a: xxxvi).

Already this brief account of Weber's way of going about the puzzle of the singularity of modern capitalism - and, more broadly, of Western civilization-suggests, in spite of the evident similarities, an approach 
that is markedly different from Marx's. Marx seems to concentrate all forces of historical change in the here and now of capitalism and bourgeois society- '[a]11 that is solid melts into air' (Marx and Engels, 1976: 487) - which uproot and dissolve the hitherto sanctified spells of tradition and repetition to finally inaugurate a progressive history. Weber's gaze, in turn, extends chiefly from the present of capitalist/bourgeois society, and the manifold evidence of Western singularity one can gather from it, to a nuanced, fragmented past from which the roots of said singularity must painstakingly be gleaned, sometimes in closer temporal proximity to the present - as exemplified by the argument developed in The Protestant Ethic - sometimes in genealogies spanning millenniasuch as when the author traces the ethical rationalism of "the West" back to the prophets of doom of Ancient Judaism (Weber, 1967). Instead of the sharp divide between pre-capitalist past and capitalist present leading one to discern in that present the seeds - and the necessity - of the socialist future, Weber's historical outlook shuns the prospective glance and instead focuses on a molten, chaotic past, where the seeds of modern Western singularity seem to be almost randomly scattered. Both chronologically and intellectually, Weber was two steps farther away from German idealism than Marx. Kant came to him through the neo-Kantian epistemologists of Baden (Oakes, 1988; Wagner and Härpfer, 2015), his conception of history was closer to Burckhardt's than to Hegel's and, like Nietzsche, he too believed he was living in a dismal, godless age (Peukert, 1989: 11-44). ${ }^{13}$ In short, for Weber, there is no objective meaning in history. Meaning is the entirely subjective product of individual human beings, who either, as historical actors, ascribe it to their actions oriented towards others or, as historians, elicit it from the inexhaustible and intrinsically irrational record of human action by ordering it according to the criteria of relevance of their own age (which, of course, they themselves help establish) ${ }^{14}$ Weber, much like Marx, was mesmerized by the novelty and peculiarity of the modern age, but unlike Marx, for him history "ended" in the present. This is why, as Karl Löwith (1993: 48) notes, while 'Marx proposes a therapy,' i.e. outlines a course of action to overcome capitalism, 'Weber has only a "diagnosis" to offer,' for his understanding of history constrains him to the task, as it were, of writing the clinical history of modernity.

\section{Of Liquids and Solids}

Weber's rejection of a progressive vision of history is crucial for understanding his analysis of modernity. However, it should not lead us to suppose that his interest in history became one of an antiquarian nature, nor much less that he flirted with regressive conceptions of history. Weber did not engage in the pessimistic variety of cultural critique that was so fashionable at the time-which explains the instant literary success 
of Oswald Spengler's Decline of the West in 1918 - and he had nothing but contempt to offer to the conservative 'dilettantes' and 'amateurs' who dreamt of a return to-a highly idealized version of - the medieval Ständestaat (Weber, 1994: 85, 91, 100). Weber's interest in the past was subordinate and instrumental to the analysis of the modern condition, a condition which, in a deep personal sense, was also his own. Therefore, even if in the treatment of the historical materials serious scholarship should strictly adhere to axiological neutrality, the purpose of elucidating the scholar's own day and age leads one unavoidably, at some point, to the formulation of judgements of value. A brilliant illustration of this is provided in the final paragraphs of The Protestant Ethic. After dense pages of careful perusal of the writings of Puritan theologians and moralists, Weber finally lets his voice be heard, and the concerns which have driven him to write the study emerge distinctly at last:

In Baxter's ${ }^{15}$ view the care for external goods should only lie on the shoulders of the "saint like a light cloak, which can be thrown aside at any moment". But fate decreed that the cloak should become an iron cage. Since asceticism undertook to remodel the world and to work out its ideals in the world, material goods have gained an increasing and finally an inexorable power over the lives of men as at no previous period in history. To-day the spirit of religious asceticism - whether finally, who knows? - has escaped from the cage. But victorious capitalism, since it rests on mechanical foundations, needs its support no longer. The rosy blush of its laughing heir, the Enlightenment, seems also to be irretrievably fading, and the idea of duty in one's calling prowls about in our lives like the ghost of dead religious beliefs... No one knows who will live in this cage in the future, or whether at the end of this tremendous development entirely new prophets will arise, or there will be a great rebirth of old ideas and ideals, or, if neither, mechanized petrification, embellished with a sort of convulsive self-importance.

(Weber, 1992a: 123-124)

This breath-taking crescendo climaxes with a reference to Nietzsche's 'last men' (Weber, 1947: 204), which Talcott Parsons's translation, both revealingly and regrettably, omits. ${ }^{16}$ The picture presented here is certainly bleak, but the 'iron cage' is not governed, to paraphrase the expression coined by Robert Michels (1915: 377) in a famous book on modern political parties dedicated to Weber, by any 'iron law. ${ }^{17}$ The future is uncertain, '[n]o one knows who will live in this cage,' but humanity, however profound the changes brought about by Western capitalism may be, still holds the key to change its condition, to aspire to something entirely new or to rediscover what was lost along the way. What is more, 'this tremendous development,' despite its menacing denouement, has also been liberating 
in several respects. To begin with, the "spirit" of capitalism, nurtured in particular (and unintentionally) by Calvinistic innerwordly asceticism, succeeded in overcoming the traditionalist resistance to novelty, and its emphasis on the solid ties to kin and soil, that everywhere opposed any prospect of significant historical change (Weber, 1992a: 23). As his subsequent studies on the religions of India (Weber, 1958) and China (Weber, 1968) show by way of contrast, only in "the Occident" did a religious ethic contribute to the dissolution, rather than to the strengthening, of traditional rule based on the sanctification of kinship ties and patriarchal authority. While everywhere else religion reinforced tradition and the history of repetition and immobilism it engenders, in certain Western settings, a religiously inspired ethical outlook towards everyday life and economic conduct emerged, whose unintended consequence was to infuse the far-reaching transformations that characterize capitalistic developments. Because history, for Weber, possesses no objective meaning nor purpose, capitalism cannot be said to have initiated a progressive history in the Marxian sense, but it no doubt constitutes a singularly powerful historical force whose 'general cultural significance' is second to none.

But not only did the "spirit" of capitalism, in general, precipitate change in an otherwise quasi-immobile world. It is also the "spirit" behind specific changes which Weber values positively. Among these, one must single out especially the correlation, in the geographical areas more densely permeated by Puritan 'innerwordly asceticism,' between high levels of capitalistic development and the attainment of unmatched degrees of individual and political freedom. The ascetic hostility to personal authorities, whose recognition would be a sign of sinful idolatry of the flesh-obedience is due to the impersonal authority of the scripture only —is, according to Weber (1992a: 94, n. 178), 'the historical basis of the peculiarities of even the contemporary democracy of the peoples influenced by Puritanism.' Moreover, Weber also credits the antiauthoritarian tendencies of Protestant sects, and not secular, humanistic Enlightenment, for the triumph of the ideas of toleration and individual rights (Weber, 1992a: 81, n. 110). To such an idea of fundamental rights, he notes in passing, 'we are nevertheless indebted for not much less than everything which even the most extreme reactionary prizes as his sphere of individual freedom' (Weber, 1992a: 83, n. 118). A few years later, in a letter to Hermann Graf Keyserling, he writes in a similar tone that one might very well smile at the 'childishness' of the principles of the French Revolution, but one owes them 'things without which life would become unbearable' (Weber, 1998: 237). ${ }^{18}$ Furthermore, in his lengthiest political essay, when the Great War drew to a close, Weber would again insist that it is 'a piece of crude self-deception to think that even the most conservative among us could carry on living at all today without these achievements from the age of the "Rights of Man" (Weber, 1994: 159). Last but not least, it was also Protestant asceticism, in particular through 
the extension of the universal priesthood to women in some denominations (e.g. Baptists), which occasioned 'the first breaches in patriarchal ideas' and insofar stood at the origin of 'the emancipation of woman' (Weber, 1992a: 105, n. 23).

However, these undeniable achievements are paradoxically threatened, as soon as they arise, by the very same "spirit" that gives rise to them, a "spirit" which appears to quickly exhaust its transformative potential and to cancel itself out. For the most far-reaching - and, again we emphasize, unintended - consequence of the whole development, as the author puts it in one of the many rich footnotes of The Protestant Ethic, is that it instils a relentless 'struggle to rationalize the world' (Weber, 1992a: 64, n. 30) which, eventually, might lead into new, terrifying forms of paralysis. Indeed, if no new prophets arise - and whence, one wonders, could they arise from? - and old ideas and ideals remain in their graves, we have to face the dark prospect of 'mechanized petrification.' Therefore, in stark contrast to the Marxian meltdown of all that is solid into air, Weberian images of Western modernity are haunted by the spectre of a new social, cultural and political immobility. The 'iron cage' or 'shell as hard as steel' and the 'mechanized petrification' metaphors in the climax of The Protestant Ethic are merely the earliest among several images expressing such an anxiety, to which one could add, for instance, the 'lifeless' (industrial) and 'living' (bureaucratic) machines as the 'congealed spirit' which slowly but surely erects 'the housing of...future serfdom' (Weber, 1994: 158) ${ }^{19}$ or the 'polar night of icy darkness and hardness' (Weber, 1994: 368), waiting for the revolutionary enthusiasm of 1918-1919 to dissipate, as it must, in order to settle in. In short, the ambivalence at the heart of Weber's account of modernity could be summarized as follows: The historical force, arising out of a peculiar combination of circumstances, which dissolved the rigid ties of kinship and tradition, is ironically the same which, as it develops and intensifies, threatens to replace them with an even more ruthless and unescapable system of domination, yet again freezing historical change. Chains made of modern steel might, indeed, be even harder and more unbending than the "primordial" shackles which tied human beings down to land, kin and patriarchal authority. ${ }^{20}$

\section{Politics 'In a Godless and Prophetless Time'}

\section{Power, Domination and Authority}

The foregoing discussion has brought us to a point where an examination of the Weberian conceptions of power, domination and authority becomes necessary. Thus far, we have (1) analysed Weber's sociological understanding of legitimacy and the importance it lays on a methodologically problematic 'belief in legitimacy' for any lasting form of rule, and (2) broadened the perspective to take into account the author's 
ambivalent vision of modernity, from which ultimately both his research programme and his chief political concerns proceed. In this section, led by the aim of fleshing out his conception of modern democracy, its prospects and predicaments, we start by focusing on Weber's understanding of these fundamental categories of both political theory and sociological analysis.

Weber did not live to complete his political sociology. ${ }^{21}$ Most notably, he did not develop and finalize sociological accounts of "state" and "nation." The corollary of his political sociology remains, thus, the trilogy of ideal types of legitimate domination-tradition, charisma and rational legality - as it is expounded at length in Economy and Society. When he wrote The Protestant Ethic in the early 1900s, Weber had not yet developed the three ideal types. Nonetheless, in its value-laden climax quoted earlier, they quite distinctly emerge from the author's tentative prospective glance. ${ }^{22}$ Indeed, the possibility that 'entirely new prophets will arise' suggests the disruption of the capitalistic development by charismatic forces, whereas 'a great rebirth of old ideas and ideals' leaves the door open to a return of traditional forms of authority. If none of the latter materializes, however, modern man will meet the fate of 'mechanized petrification,' which involves inter alia the establishment of comprehensively developed rational-legal, i.e. bureaucratic, forms of rule. Of course, the anticipation of the three ideal types in this passage acquires strong normative tones which can misleadingly suggest both that there still was a way out of the cage - through charisma or tradition - and that the triumph of rational legality, as a catalyst of 'mechanized petrification,' is an undesirable phenomenon. Quite on the contrary, in fact, even if Weber's conception of history ends in the present and abstains from formulating any laws of historical necessity, it is evident for him that the 'tremendous development[s]' of capitalism and bureaucracy are in a sense inexorable, introducing certain economic, cultural and political changes which, for better or worse, have come to stay. Moreover, the triumphs of bureaucracy and rational-legal legitimacy, despite the bleak spectres they summon, have also contributed greatly to the cause of human freedom. Ambivalence is, yet again, the keyword here - and a fruitful way to grasp it is by focusing on a text which, belonging neither to his social scientific output nor to his political writings in the strict sense, contains the key to Weber as a political theorist.

Politik als Beruf was published as a booklet in 1919, based upon a lecture delivered in January of the same year at the request of a progressive, politically diverse student association in Munich. Speaking of ambivalence, already the title is a case in point. In fact, none of its extant canonical translations-Politics as a Vocation (Weber, 1946: 77) or The Profession and Vocation of Politics (Weber, 1994: 309) — does justice to the two conflicting yet ineradicable dimensions of politics - its modern professional side on the one hand, the personal spiritual calling on the other 
hand-conveyed by the German word Beruf. ${ }^{23}$ Let us be reminded here that the starting point for Weber's analysis of the religious saturation of earthly occupations in The Protestant Ethic had been Martin Luther's concept of Beruf, which Weber himself renders in English with the word "calling" (Weber, 1947: 63; 1992a: 39). ${ }^{24}$ Now, even if, as the author asserted in the lecture on Wissenschaft (Science) als Beruf, given year and a half earlier to the same audience of "free students," we live in a 'godless' age (Weber, 1946: 153), that does not mean that intellectual and political activities have become deprived of any spiritual content or purpose. What it does imply is that such spiritual content must take into account and be reconciled with certain inescapable features of the modern condition. This is, indeed, the fundamental tension that permeates both Munich lectures, according to them a singular status within Weber's auvre.

After their first edition, in 1919, in a volume on intellectual work as a vocation (geistige Arbeit als Beruf) that gathered the contributions to the student association lecture series, they were later republished in the collections of, respectively, Weber's methodological and political writings (Weber, 1951: 566-597; 1971: 505-560). That, however, was a misplacement, for neither does the one touch upon the dense epistemological conundrums that figure prominently in the methodological papers nor is the other absorbed with the most urgent political topics of the day, which have always provided the occasion for Weber's political speeches and journalistic activity. The editors of Weber's complete works have corrected this and published the two lectures in one autonomous volume (Weber, 1992b). As Wolfgang Schluchter remarks in the introduction to that volume, the lectures should be understood as philosophical texts in a broad sense, where the author seizes the occasion provided by the lecture series to consider the nature and prospects of both science and politics as domains of human action (Weber, 1992b: 1). Especially the first lecture, on science, made quite an impression among the student audience. The one on politics less so, and that is not the work of pure chance or momentary inspiration. ${ }^{25}$ By 1919, it appears that Weber had made a definitive choice between the 'two icons' (Mommsen, 1989: 3) in his life, choosing science and scholarship over politics. In fact, according to Radkau (2013: 742), Weber was considering to decline the invitation for the lecture on politics, changing his mind only when he found out that the organizers were planning to invite Kurt Eisner to deliver it instead of him. Weber loathed Eisner, the independent social-democrat and radical pacifist who proclaimed the Free State of Bavaria in November 1918 and maintained that Germany was to blame for the war. For him, Eisner epitomized the sort of romantic dilettantism that ought to be strictly kept away from politics. Hence, to avoid having Eisner preach his revolutionary romanticism and uncompromising stance on the war-guilt issue to the Munich students, Weber decided to take the stage after all. ${ }^{26}$ But he approached 
the topic from a scholarly perspective, not allowing the political turmoil of post-war Munich - apart from a few side remarks - to enter the lecture hall. This detached attitude, and the level of abstraction it operates upon, explains not only the less enthralling effect upon the audience, when compared with the previous lecture on science, but also why the text based upon the lecture would grow into a classic of modern political theory.

In the first few pages, one encounters a series of 'quasi-definitions' (Palonen, 2002: 34) of politics. These highlight certain aspects of the multifaceted concept, but obscure and neglect others, suggesting that the thought of the author on the topic was still in flux. A very broad understanding of politics, 'embracing every kind of independent leadership (leitende) activity' be it at the level of public institutions or in the most intimate circles - 'we even talk about the policies of an astute wife in her efforts to guide her husband'-introduces the discussion (Weber, 1994: $309-310){ }^{27}$ Even if this is certainly too broad a concept, it recalls the distinction between the politician and the bureaucrat which the author elaborates at length upon in many of his political writings. Politics qua leadership means to take the initiative and set the course of action, and thus cannot be confused with administering everyday affairs according to written regulations or habit. However, this broad initial reading of politics is followed by a radical move of conceptual restriction: 'Today we shall use the term [politics] only to mean the leadership, or the exercise of influence on the leadership, of a political association (Verband), which today means a state.' Thus, politics as leadership is circumscribed to the institutional sphere of the state, which, in turn, is defined by its 'specific means' and by the claim it (successfully) lays 'to the monopoly of legitimate physical violence within a certain territory' (Weber, 1994: $310-311) .{ }^{28}$ Politics, the state and violence seem, hence, to be intimately connected to each other.

This restrictive move raises an important question concerning the specificity and novelty of Weber's conception politics. By defining the state according to its means - violence-instead of its substantive aims or ends, Weber no doubt departs from the teleological institutionalism that dominated the study of politics as a doctrine of the state, as a Staatslehre, until the First World War, especially — though not only - in Germany. However, a sociological redefinition of the state does not necessarily signal the overcoming of a state-centred conception. Kalyvas (2008: 29) observes in this respect that Weber still 'equated the state with the political in a way that the former successfully occupies the entire terrain of the latter.' From this point of view, Weber might very well have replaced a formal-normative institutionalist approach by an empirically sharper, sociological one, but he nevertheless left the state-centred paradigm of nineteenth-century political theory intact. Things, however, are not as simple. As Palonen (2002: 29) keenly argues, Weber's focus on the state merely sets a frame of analysis by isolating an eminently political terrain. 
The terrain of the state, nonetheless, does not exhaust the concept of politics, for there are surely phenomena beyond the realm of the state which possess, in Weber's view, specifically political dimensions and properties. Weber in fact stands here at the threshold that separates an understanding of politics still predominantly oriented towards the state from one where the broader, and much more elusive, concept of power takes centre stage. Undoubtedly, Weber's sociological approach dynamites the straightforward opposition of state and society as independent entities, and denies the state the capacity to prescribe society's goals, as it were, from above. ${ }^{29}$ Indeed, following the moment of conceptual restriction to the state, Weber advances another 'quasi-definition' of politics. Contrary to what its phrasing suggests - the adverb 'then' (also) is rather misleading there- this tentative definition points in an altogether different direction, significantly loosening the restriction by moving the concept of power to the foreground at the expense of the state:

In our terms, then, 'politics' would mean striving for a share of power or for influence on the distribution of power, whether it be between states or between the groups of people contained within a state.

(Weber, 1994: 311)

Power is the essential element of politics here. States, of course, are relevant as actors striving for power in the international arena or as the geographical units within which such striving occurs, but the state does not define that which is political. Power, so it seems, is ultimately the best candidate, in Weber's eyes, to appear as the element of politics. But what does power mean?

In general, we understand by "power" the chance of a man or a number of men to realize their own will in a social action even against the resistance of others who are participating in the action.

(Weber, 1978: 926)

Power is thus understood as a 'chance,' a mere possibility, because of its uncertain, contingent and easily reversible nature. This explains the incessant striving for it. Perhaps more than scarcity - the fact that there is never enough power to satisfy everyone-it is the fluidity of power that makes it so hard to attain and, especially, to preserve. Therefore, power becomes the object of ceaseless struggles between all who strive for it (Weber, 1978: 53, 938; 1994: 154, 161). But it does also, even if only temporarily, crystallize into more stable forms. When that happens, 'a special case of power' (Weber, 1978: 941) emerges, which the author names domination or rule (Herrschaft):

To be more specific, domination will thus mean the situation in which the manifested will (command) of the ruler or rulers is meant 
to influence the conduct of one or more others (the ruled) and actually does influence it in such a way that their conduct to a socially relevant degree occurs as if the ruled had made the content of the command the maxim of their conduct for its very own sake. Looked upon from the other end, this situation will be called obedience.

(Weber, 1978: 946) ${ }^{30}$

Domination, therefore, mitigates the capricious plasticity of power in a number of closely interrelated ways. First, it establishes an asymmetrical relationship between rulers and ruled, between command and obedience. Second, there is more predictability in relations of domination, as opposed to those of power, since the will of rulers not only intends to influence, but 'actually does influence' the behaviour of the ruled. ${ }^{31}$ Third, continuous patterns of domination become distinguishable and tend to acquire an organized form which reinforces their permanence. Finally, and most importantly, domination is usually internalized by the ruled, who thereby acknowledge - and, to some extent, mask - the situation of heteronomy they find themselves in.

Such process of internalization, going back again to the Munich lecture, is what leads to the emergence of authority, i.e. of a belief in the legitimacy of the state as 'a relationship of rule (Herrschaft) of human beings over human beings.' The introduction of the idea of domination (or rule) in the quest to define politics serves to bring the concept back from the restless magma of power, where it had just been thrown, to the more structured and consolidated bounds of the state. In this context, Weber briefly presents his three ideal types of legitimate rule, which suggest different bases for 'the belief in legitimacy' sustaining the voluntary submission of the ruled to the patterns of domination consolidated by the state. Two of them seem to rest on the natural tendency to conform to what the status quo prescribes: Traditional authority derives its appeal from the 'habitual predisposition to preserve' what has always been, while rational legality rests 'on a predisposition to fulfil one's statutory obligations obediently.' Charisma, by contrast, connects ruler and ruled more immediately and personally based on the 'trust' and on the 'devotion' of the latter to the extraordinary qualities of the former. Charisma 'is the authority of the exceptional,' not of habit or written statutes. It is scarcely surprising, hence, that in a lecture on politics the author decides to single out just this type of legitimacy (Weber, 1994: 311-312).

\section{A Shrinking Scope for Political Innovation: Charisma, Modern Rationalization and Bureaucracy}

The focus on charisma can furthermore be explained, looking at the structure of the Munich lecture, by the subsequent step in the author's argument. After the opening enquiry into the nature of politics, Weber 
shifts the attention to the historical forms of political activity. Because charisma is the only intrinsically personal type of authority, then surely 'this is where the idea of vocation (Beruf) in its highest form has its roots' (Weber, 1994: 312). ${ }^{32}$ Yet, charisma is not only essential to understand politics as a personal calling and as a modern profession. More than that, in Weber's view, charismatic legitimacy emerges as the one distinctively political form of authority.

As Palonen (2002: 34-35) perceptively points out, Weber's vision of politics as striving and struggle has at its core a transformative impulse, a drive to change the status quo. Efforts to preserve power are, according to this perspective, only derivatively political, since they must first be activated by the striving of those who wish to alter the current distribution of power. From the point of view of the asymmetry involved in every relation of domination, such vision entails that politics should be conceptualized as, in essence, a bottom-up phenomenon. Now, it is undeniable that, among the Weberian ideal types, charisma appears as the only form of authority that corresponds to such transformative dimension of politics. By contrast, when Weber's analytical focus drifts to the quest for consolidated patters of social interaction, for 'generalized uniformities of empirical process' (Weber, 1978: 19), tradition and rational legality become more relevant as ideal types of legitimate rule. Unsurprisingly, charisma is only referred to in passing, as an exception to tradition and rational legality, in 'Basic Sociological Terms,' a text written in 1920, which serves as the introduction to Economy and Society, where Weber's understanding of sociology appears to be moving in a behaviourist, empiricist-positivist direction (Weber, 1978: 37-38).

To be sure, the logical relations between the ideal types of legitimate rule, as well as the historical relations between their "real" empirical variants, are controversial issues. As the main conceptual and methodological tools of Weberian sociology, the ideal types are, at their highest level of abstraction, trans-historical categories which are able to travel across time and space, evidencing their descriptive or explanatory potential in various contexts. However, in broad world-historical terms, there is also a developmental trend travelling through them, as the retrospective approach adopted in the exposition of the sociology of domination in Economy and Society clearly suggests. There, Weber begins by looking at rational legality (the ideal type) and the bureaucracy (the historical variant), because 'it is best to start from modern and therefore more familiar examples' and move then to the historically older types and forms (Weber, 1978: 213). In another context, Weber posits that 'tradition is the oldest and most universal type of legitimacy' (Weber, 1978: 37), and from a historical perspective, such statement can hardly be denied. However, from a logical viewpoint, the priority of tradition relative to charisma is ultimately impossible to determine, as the issue would inevitably lead us to a chicken-or-the-egg type of causality dilemma. ${ }^{33}$ One thing is for 
sure, though: Rational legality comes last, and its rise, manifested by the development and spread of bureaucratic forms of rule, is the phenomenon that begs for an explanation. In that sense, in view of the overarching developmental trend that travels through the ideal types, it is advisable not to treat them on a formally equal footing, but rather to distinguish sharply between durable and ephemeral, or ordinary and extraordinary, forms of rule, i.e. between tradition and rational legality on the one hand, and charisma on the other hand. The development Weber wishes to elucidate, and which he views as a Western singularity, is that which leads from tradition to rational legality, from one stable, ordinary form of domination to another, entirely new one (Schluchter, 1981: 106-121). ${ }^{34}$

From such a developmental, world-historical perspective, the importance of charisma seems to recede. Whether, concretely, they contribute to the grand transition to rational-legal domination or, on the contrary, lash back at it, one would think that the eruptions of charismatic authority, because of their ephemeral nature, have little world-historical significance. That, however, would be too hasty a conclusion. For the developmental trend that takes us from pre-modern traditional domination to modern rational rule is, according to Weber, not driven by an immanent impulse for change. Stable rule and ordinary life, both in their traditional and modern rational variants, tend, in Weber's eyes, not towards continuous change and reinvention, but rather towards immobility and petrification. Of course, the rise of Western rationalism has changed the world and mankind profoundly, but at the end of such 'tremendous development,' as the climax of the Protestant Ethic warns us, we face the grim prospect of the torpor of rational rule. According to Weber, there is only one interruptive force in history that, however transiently, can break through the inertia of both pre-modern and modern everydayness. That force is what he calls charisma:

$[\mathrm{C}]$ harisma, in its most potent forms, disrupts rational rule as well as tradition altogether and overturns all notions of sanctity. Instead of reverence for customs that are ancient and hence sacred, it enforces the inner subjection to the unprecedented and absolutely unique and therefore Divine. In this purely empirical and value-free sense charisma is indeed the specifically creative revolutionary force of history.

(Weber, 1978: 1117)

In a way, therefore, despite its precarious and transient nature, charisma contains the key to the problem of domination. The powers of the ordinary and the everyday can only be grasped, if one is able to discern how they tame the disruptive impact of charisma. The nature and features of any consolidated pattern of domination, be it of a traditional or rational-legal kind, become fully understandable only as instances of the inevitable transformation of charismatic disruptions of rule, of their 
(re)conversion to the rigidity of everyday practices. Therefore, Weberian concepts such as 'hereditary charisma' or 'charisma of office' (Weber, 1978: 248) - and more generally the idea of a 'routinization of charisma' (Weber, 1978: 246ff., 1121ff.) — where the latter meets either tradition or rational legality, not only constitute mixed forms which stand analytically in between the abstraction of the ideal type and the messiness of empirical reality but also convey a derivation from, as it were, an evanescent focal point of domination that renders lasting, ordinary forms of rule intelligible. ${ }^{35}$

The main source of Weber's conception of charisma is Rudolph Sohm's (1892) historical interpretation of Canon law. Sohm, whose lectures Weber attended in Strasbourg, used it to refer to rule by the ineffable divine grace conferred upon the early Christian community, as opposed to the later legalistic and bureaucratic development of the Roman Church. ${ }^{36}$ To be sure, Weber gave the concept a much broader meaning and took it beyond the confines of Christian theology and church history (Smith, 1998). Nevertheless, this origin already indicates that not only does charisma contain the key to the sociology of domination, but it is also the most suited concept to establish the nexus between the latter and the sociology of religion. In the final analysis, charisma, and more precisely its transformation, connects both the sociology of domination and that of religion to Weber's grander, central attempt to explain the rise of Western rationalism: ${ }^{37}$

Charisma is a phenomenon typical of prophetic movements or of expansive political movements in their early stages. But as soon as domination is well established, and above all as soon as control over large masses of people exists, it gives way to the forces of everyday routine.

(Weber, 1978: 252) (38 $^{38}$

Now, as 'forces of everyday routine,' tradition and rational legality stand in sharp contrast to each other. But despite the long pages Weber dedicates to the analysis of traditional forms of domination, from the primordial variants of patrimonial rule one encounters in practically all civilizational contexts to European feudalism, the puzzle that truly captivates the author, where he sees the fate of mankind at the balance, is that of rational domination. In fact, the very analysis of traditional forms of rule is oriented to a large extent towards the embryonic signs of rationalization they already contain. At this stage, one should emphasize that Weber's notion of rationalization has scarcely anything to do with the idea of reason as it was understood - and worshiped - by Enlightenment philosophy and natural law theory; for him, the story of Western rationalization is not a tale of moral progress. Regarding such notion of reason, Weber (2008: 104) referred once in a letter to 'the infinitely naïve, childish belief in the power of reason. ${ }^{39}$ Anyone familiar with his 
sociology knows, however, that the power of the rational, on the contrary, can hardly be overestimated; it seems to be both ubiquitous and inexhaustible. What the latter does to charisma is roughly this: Charismatic movements, be they religious and/or political, in their struggle against the status quo and especially in their quest for hegemony over the realm of socially significant values which sustain the patterns of domination, seek the support of as many followers as possible. In order to enlarge their social bases, their doctrines, which originally rested on 'the inner subjection to the unprecedented and absolutely unique,' are reformulated in ever-more abstract, universally appealing terms, allowing them to overcome class and status barriers. Once the movement triumphs, in the specific sense that its ethos becomes that of the community as a whole, and as a sign of that triumph, domination crystallizes into fixed, regular practices that as such put an end to the fleeting instant of charismatic disruption (Weber, 1978: 1180).

The contrast between substantive or value-rationality and formal or instrumental rationality, which figures so prominently in Weber's writings on law and economics, is often invoked to explain his conception of rationalization, the idea being that the latter involves an increasing emphasis on form and instrumentality to the detriment of substance. While, as an identification of a general trend, that is surely undeniable, one must nevertheless note that considerations of substance and value are ineradicable, even by the most thoroughly developed systems of rational-legal domination. Furthermore, I do not think that the idea of instrumentality, with its focus on the adequacy between means and ends, penetrates to the core of Weber's concept of rationalization. Rather, I would suggest to focus on the notions of routine and procedure, for what is ultimately at stake is the emergence and expansion of methods and techniques which in themselves, irrespective of their orientation towards either unconditional substantive values or strategic goals, bring order to human life, and thus correspond, if not to an instinct, then to a basic and perhaps universally sensed human drive. In this regard, Weber's biographer has perceptively suggested an affinity between his concept of rationalization and that which Ernest Jones (1908) developed in psychoanalysis, that is, 'as denoting a procedure which aims to provide an in itself irrational behaviour with an - either visually, logically or morally - acceptable form,' and which appears to be present to some degree in every instance of meaningful social interaction, 'even in the magic rites of supposedly "primitive peoples"' (Radkau, 2013: 544). The sociology of music, which is considered to contain Weber's first systematic application of the concept of rationalization (Sukale, 2002: 300), is a case in point (Weber, 1921). ${ }^{40}$ The study, in fact, has very little to do with what one would more immediately associate with a sociology of music, for it deals only secondarily with the social conditions surrounding musical production. The main topic, instead, is the rationalization of the very substance 
of music in Western Europe as of ca. 1600, i.e. the birth of notated tonal harmony as a technique which, to paraphrase Radkau, sought to provide an in itself irrational artistic expression with an audibly acceptable form. As the presence of less systematized harmonic practices in most musical traditions-Weber compares classical Western especially with classical Indian music in this regard - shows, the drive for order through routine and procedure is arguably a universal phenomenon, but in "the Occident," according to the author, it has reached a degree of intensity as never before in human history.

Such intensity climaxes in the quintessential historical configuration of rational-legal domination: the bureaucracy. Weber equated the transformation of charisma into modern rational domination with the expansion of bureaucratic administration, and so much so that, as Schluchter (1981: 109) points out, he uses the adjectives "rational," "legal" and "bureaucratic" almost interchangeably. While, for Marx, the crux of capitalism lies in the separation of the worker from the ownership of the means of production, for Weber, the hallmark of the modern age is rather the separation of the administrative staff from the ownership of the means of administration, which become the property of large-scale organizations rather than individuals (Weber, 1978: 980ff.). '[W]ithout regard to the person' (Weber, 1978: 600) is the guiding principle of bureaucratic rule, which, in contrast to traditional types of domination, is bounded by formal hierarchies and written statues rather than personal loyalties or precedent. Much like his vision of modernity in general, Weber's verdict on the bureaucracy is also strikingly ambivalent, punctuated by a blend of fascination and horror (Mommsen, 1989: 109-120). Fascination goes for its 'technical superiority over any other form of organization' (Weber, 1978: 973), ${ }^{41}$ and the immense possibilities thus opened for modern societies, as well as for its breakdown of the '[a]uthoritarian powers resting on personal loyalty, such as theocracy and patrimonial monarchy' (Weber, 1978: 811) that constituted traditional rule. The latter source of fascination, however, is at one and the same time a source of anxiety, for bureaucratic administration might not just accomplish, as it usually does with unmatched efficiency, the routinization of charisma, but also its 'castration' (Weber, 1978: 1137) and therewith the foreclosure of cultural and political innovation, the advent of the much-feared horizon of 'mechanized petrification.'

Bureaucratic domination, in the final analysis, is the by-product of a rationalism that has 'consistently worked through to the disenchantment of the world and its transformation into a causal mechanism' (Weber, 1946: 350). It rests on the assumption, as Weber (1946: 139) puts it in Wissenschaft als Beruf, 'that one can, in principle, master all things by calculation.' To inhabit this disenchanted and fully calculable world epitomized by the bureaucracy means, therefore, to live not just in a 'godless,' but also in a 'prophetless time' (Weber, 1946: 153), in an age that 
increasingly safeguards itself from the risk of prophecy that inseminates charisma as the 'revolutionary force of history.' As Peukert (1989: 12-15) notes, this dual characterization of the modern age acknowledges $\mathrm{Ni}$ etzsche's diagnosis, yet at the same time repudiates the consequences that the philosopher extracted from it. For Nietzsche remained stuck in a reactive, exalted form of prophesizing that, from Weber's viewpoint, was both scholarly and politically irresponsible. '[A]rmchair prophecy' was an escapist 'ersatz' (Weber, 1946: 153), an illusory promise of re-enchantment, an easy way out that allowed one to avoid facing up with the exigencies of the age. Contrary to what cultural critics in the stead of Nietzsche-as, for instance, those gathered around the poet Stefan George - fantasized about, Weber maintains soberly that there is no escape from the disenchanted world in which modern humankind must live, and this means of course also no escape from bureaucratic domination. The question was rather whether, within this world where Weber was destined to live, there is still room for cultural and political innovation, despite the ineluctability of bureaucratic rule and its intrinsic calcifying tendencies. Radkau (2013: 478-483) submits that not only did Weber greatly overestimate the powers - and the dangers connected to them-of the Prussian-German bureaucracy of his day but also ignored its reformist potential. ${ }^{42}$ And that might very well be the case. Ultimately, Weber's conceptions of the bureaucracy and bureaucratization owe much more to a philosophy of history than to empirical observation. However, such philosophy of history acquires a sharp - and, in a way, an almost prophetic - analytic edge when read retrospectively against the backdrop of the Nazi and Soviet bureaucratic "machines," whose development Weber himself did not witness and, in certain other decisive regards, as one will see, did not anticipate at all. The remainder of the chapter focuses, thus, on the Weberian quest to salvage a horizon of innovation and renewal in modern democracies, as it emerges especially in his wartime and post-war political writings.

\section{Charismatic Leadership and the German Democratic Predicament}

\section{Nationalism, Parliamentarism and Democracy}

Max Weber was a politically engaged man throughout his life. Even though the only time he decided to run for office, in the elections to the constituent assembly in 1919, ended in failure, he exerted considerable influence on contemporary politics through his journalistic activity and in advisory capacities ${ }^{43}$ - certainly more influence, in any case, than most scholars today can dream of. Born into a well-to-do liberal household, Weber was a first-hand witness to the fiasco of German political liberalism in the second half of the nineteenth century. As a child and teenager, 
he must have overheard the notes of disappointment and frustration of the national-liberal parliamentary opposition, whose members often met in his family's Berlin-Charlottenburg home, as it was outmanoeuvred by Bismarck in the late 1870s. The legacy of Chancellor Bismarck constitutes, indeed, Weber's life-long political concern. His attitude towards the "iron Chancellor," however, was marked neither by the bitterness of the liberals who had failed to further the cause of parliamentary government, nor by the enthusiasm of those who embraced militarism and monarchism in the euphoria of 1870 . Weber was still a child when the Prussian armies triumphed in Königgrätz and Sedan. By the time he reached adulthood, the political atmosphere had sobered up, as the new Reich struggled with deep-seated social problems. Therefore, to Weber Bismarck did not appear as a charismatic war leader. Still, even if often disagreeing with the political course set by the Chancellor and largely deploring its legacy, he admired the shrewd statesman's mastering of power politics. In an oft-quoted passage from his youth letters, Weber laments the adoption of male universal suffrage as 'the fundamental mistake...of Bismarckian Caesarism' (Weber, 1936: 143) ${ }^{44}$ standing at the origin of a causal chain leading, first, to the electoral growth of the SPD, then, as a reaction, to the repressive measures of anti-socialist legislation and, ultimately, to the restriction of the civic and political freedoms which the liberals had conquered. Later, however, Weber comes to evaluate the shortcomings of Bismarck's legacy in a different, albeit equally critical, light. The problem was not so much the Chancellor's speculation with the conservative instincts of the masses, but rather the neutralization of the capacities of the representative institution now elected by all male citizens of the Reich.

Weber's basic political orientation was liberal and national, a combination familiar and taken to be unproblematic in the nineteenth century, but which has been the subject of much discussion in the secondary literature concerning the more precise contours of the varieties of "liberalism" and "nationalism" at stake there, and their relation to each other (Mommsen, 1974b: 37-72; Bellamy, 1992; Palonen, 2001; Weichlein, 2007). The issue of nationalism, in particular, has been somewhat overproblematized, engendering a relatively spurious controversy between those who stress Weber's nationalist vows and those who de-emphasize them.

It seems quite evident to me that, despite the not just Nietzschean, but rather social Darwinist undertones of his 1895 inaugural lecture at the University of Freiburg (Weber, 1994: $1-28),{ }^{45}$ no one in their right mind could consider Weber a chauvinist German nationalist. To the contrary, in his political writings, he actually reverses the thesis of a positive German Sonderweg by exposing the institutional backwardness of Germany in comparison with its Western neighbours (and, particularly, with Great Britain), thus anticipating the negative reinterpretation of the Sonderweg thesis that would become predominant in German historiography after the Second World War. In point of fact, already The 
Protestant Ethic can be read in such a light, for the rational spirit of Lutheran entrepreneurs might have ranked higher than that of Catholics in Germany, but it still lagged behind that of capitalists in countries under Calvinistic and Puritan influence such as Holland and England. Furthermore, and perhaps more decisively, Weber refused to engage in the intellectual sacrifices of war propaganda, unlike, for instance, most of the big names in neo-Kantian philosophy from his Heidelberg milieu. ${ }^{46}$

However, and despite the best conceptual-historical efforts of Palonen (2001), one can hardly maintain without indulging in a reductive reasoning that Weber, as the staunch nominalist that he was, used the concepts of "nation," "national" and "nationalist" in his own unique way, thus making the very act of relating them to the meanings they possessed beyond the specific context of Weber's auvre somehow illegitimate. As if Weber was unaware of such meanings and the consequences which might ensue from using the concepts, or as if, which is equally unconceivable, he thought that his conceptual creations could and should, especially in matters of immediate political significance, stand tall above, and totally unrelated to, the ordinary meanings given to words. It is true that Weber only very rarely grafted an "ism" (or an "ist") on "national." In the fragmentary discussion of the concept of "nation" in Economy and Society, Weber gives in to the sheer impossibility of offering a definition which could be validated empirically, and places the concept within the (irrational) sphere of values and emotions (Weber, 1922: 627-630; 1978: 921-926). There, also, he takes note of the predestination of intellectuals 'to propagate the "national" idea' (Weber, 1978: 926). ${ }^{47}$ Now, Weber himself, far from dodging that fate, embraced it. Indeed, in the proviso to his most important political tract, Weber discloses in all clarity his commitment to the German national cause:

Anyone for whom the historical tasks of the German nation do not take precedence, as a matter of principle, over all questions of the form the state should assume...will not be opened to the arguments advanced here.

(Weber, 1994: 130) ${ }^{48}$

In this sentence, one can discern the fundamental aspects of Weber's "nationalism." To begin with, it is very clear that the author embraces the belief that the nation constitutes the only framework for politics and culture in the modern world that is capable of dictating 'historical tasks.' Furthermore, he also posits axiomatically that such a national historical mission ranks higher than all questions pertaining to the intrinsic merits of different political and institutional arrangements. In so doing, Weber moves undoubtedly close to some of the key components which generate the relatively autonomous and self-sustained universe of meaning of nationalist ideology (Freeden, 1998). However, in contrast to 
many nationalist thinkers, Weber is fully aware that his choice for the national cause has no rational justification, that it is a matter of adherence to ultimate values which lie beyond the reach of rational discourse and, therefore, cannot be forced upon the unbelieving. The modern age, in fact, after the breakdown of all-encompassing religious cosmologies, is according to him marked by such pluralism of ultimate values. Consequently, those who, unlike Weber, orient their political thinking and action not towards the ultimate value of the "nation," but towards those of, say, "universal humanity," "international solidarity" or "tradition" will hold very different views on matters of constitutional design - views which Weber intends neither to challenge nor even to engage with. And yet, despite this prefatory profession of faith, Weber does never quite abandon the horizon of rational discourse in his political journalism. The boundaries between the-ideally-value-free realm of scholarship and the value-laden domain of politics are in reality blurred; both spheres intersect constantly and cannot be understood in isolation. This is especially the case, if one aims to elucidate Weber's views on parliamentary democracy.

Looking ahead at the inevitable post-war reconstruction of German domestic politics as the war was still being waged, Weber argues vehemently, in two of his longest political essays, for the establishment of universal-suffrage democracy at all levels - referring, especially, to the state of Prussia, where a feudal three-tier electoral system was still in place - and for the extension of parliamentary prerogatives. The author, to be sure, was well aware that parliamentarization and democratization, far from being synonymous, 'are often at odds with one another' (Weber, 1994: 210), given that the basis of parliamentary government, as the history of British parliamentarism attests to, is aristocratic rather than democratic. Nevertheless, he was firmly convinced that, in a modern nation-state, one could only have democracy through parliamentary government. To properly understand Weber's case for parliamentary government, one must, however, take a step back and briefly return to his sociology of domination.

A question that immediately arises if one does so is that of the relationship of "democracy" to the sociological typologies of domination. Historically, modern democratic movements and ideas have their origin in what Weber, in the older part of Economy and Society, conceives of as the 'non-legitimate domination' characteristic of the Western city. According to him, the emergence of cities with a claim to autonomy vis-à-vis traditionally legitimated patrimonial domination is, again, a Western singularity. These cities constituted the scene both of patrician resistance against legitimate traditional rulers and of popular uprisings against patrician domination, in other words, the scene both of patrician usurpation and of popular revolution (Weber, 1978: $1220 \mathrm{ff}$.). However, such 'non-legitimate domination' is not an ideal or pure type capable of trans-historical 
travelling. On the contrary, Weber treats it as a historical peculiarity of ancient and medieval cities in "the Occident," which have experienced episodes of usurpation and revolution that disrupted the extant patterns of 'legitimate' rule. As we have seen earlier, such disruptive episodes fall, more generally, under the ideal-typical category of charismatic domination, but from the viewpoint of the genesis and development of modern democracy, it is surely worth emphasizing the specific claims of revolutionary leaders in Western city-states to represent "the people" in their struggles against royal or patrician rule. Yet, the locus of modern democracy is not the city, but the nation-state, and with the increase in territory come requirements of administration that can only be fulfilled by rational-legal forms of domination. In addition, formal rationalization can also give more concrete expression to the democratic idea of a community of equals, by rendering it as the equality of all citizens before the law.

Therefore, while from the point of view of political leadership and innovative potential modern democracy relates intimately to charismatic authority, it can only guarantee for itself continuity and stability by relying on the principles and methods of rational-legal rule. In a later, posthumously published essay on 'The Three Pure Types of Legitimate Domination, ${ }^{49}$ Weber treats democracy as a variety of charismatic legitimacy, namely, as an anti-authoritarian reinterpretation of charisma. The reinterpretation entails a reversion of the original causal nexus: The authority of the charismatic leader stems not anymore from intrinsic exceptional qualities which per se command the devotion of the followers - in the pure form of charismatic authority, obedience, far from being a matter of choice, is owed to the ruler that proves to be touched by grace-but rather from the selection of the leader by the followers. Indeed, democracy turns 'the free recognition [of the ruler] by the ruled' via formal electoral mechanisms into 'the prerequisite of legitimacy and its basis' (Weber, 2005: 741-742).$^{50}$ By doing so, however, democracy also threatens to transform political leaders into mandataries of the ruled, and ultimately into bureaucrats entrusted with the task of carrying out the will of those who elect them. Weber concludes by noting that the difference between an elected leader (Führer) and an elected official (Beamte) lies then solely on the meaning that the person at stake attaches to the political office and conveys both to direct subordinates and to the voters. In the final analysis, hence, it seems to be a question of personality: "natural-born" leaders will act according to their own judgement and feel personally responsible for the consequences of their actions, whereas bureaucrats "by nature" will perceive themselves to be acting under the strict instructions of their electors, without a sense of personal commitment and responsibility (Weber, 2005: 742).

Thus, when it came to the reform of the German political system in the aftermath of the Great War, the main question for Weber was the following: Which type of personality would the design of political institutions 
attract and select? The establishment of equal and universal suffrage at all levels was, for a number of reasons, a basic political imperative for the post-war future (Weber, 1994: 98-103). However, the trend towards democratization, by emphasizing the dependence of the rulers on the ruled, reinforced at one and the same time an 'all-powerful trend towards bureaucratisation' (Weber, 1994: 159). The experience of an impotent parliament vis-à-vis the imperial government and its bureaucracy, which constituted the bottom line of Bismarck's political legacy, led Weber to believe that only a powerful parliament could put a check on bureaucratic rule. Weber's conception of parliamentary rule went, therefore, beyond the typical - in his own words, 'negative' and 'antiquated' (Weber, 1994: 106) - liberal priorities concerning the assurance of spheres of freedom from governmental intervention. What made the spectre of bureaucratization so frightening in Weber's eyes was not so much the menace it might harbour for individual rights and liberties, but rather the dark promise of an era of political petrification where rational-legal forms of rule would become impervious to change. Among the "remnants of "individual" freedom' Weber (1994: 159) wished to rescue from the inexorable progress of bureaucracy ranked, foremost, the creative freedom of the political leader, which alone could catalyse innovation.

In his political writings, Weber expands on the difference between the bureaucrat and the political leader by contrasting their diametrically opposed relations to the realm of the public struggle for power. While the bureaucrat, who ideally performs official business untainted by 'love, hatred, and all purely personal, irrational, and emotional elements which escape calculation' (Weber, 1978: 975), should be kept at bay from such struggle, the political leader must vie for power in the contingent, capricious and often tragic circumstances of a public contest. Therefore, politics requires a personal commitment to a cause which breaks down the rigid distinction between public office and private life that lies at the heart of bureaucratic rule (Weber, 1994: 354-355). The reason why bureaucrats fail when they step into the politicians' shoes has to do with the sudden absence of the framework which organized and justified their activity as bureaucrats. When the bureaucrat steps out of the 'living machine' which guarantees insulation from the public struggle for power, from a domain of competing passions and causes, he soon finds out that most of the qualities which made him a competent official are useless-or even disadvantageous - in the political arena. As Weber avers:

The official should stand 'above the parties,' which in truth means that he must remain outside the struggle for power of his own. The struggle for personal power and the acceptance of full personal responsibility for one's cause (Sache) which is the consequence of such power-this is the very element in which the politician...live[s] and breathe[s].

(Weber, 1994: 161) ${ }^{51}$ 
For Weber, the extension of parliamentary prerogatives was essentially an instrument to further the rise of political leaders, i.e. to select and refine the latter's intrinsic charismatic qualities. While a parliament devoid of legislative initiative and condemned to sterile protesting, such as the German Reichstag until the end of the First War, had hindered the rise of personalities endowed with the charismatic qualities of leadership, one which, on the contrary, possessed the right of initiative and, especially, the resources to control the secretive workings of the state bureaucracy could, according to Weber, develop into a greenhouse of "true" political leaders. Yet, an increase in the capacities of parliamentary government places new demands, in terms of workload and specialization, on the members of parliament. To meet such demands, as Weber (1994: 176-177, 318) acknowledges, parliamentarians will most likely have to become professional politicians, thus living not only "for" politics in the sense of personal dedication to a cause, but also "from" it in a strict material sense. This, in turn, begets an obvious question: Does not the professionalization of politics, as the inevitable consequence of strong parliamentary government in a mass democratic context, reinforce rather than counterbalance the 'all-powerful trend towards bureaucratisation'? More precisely, will not the members of parliament tend to develop rigid links with the already highly bureaucratized, or rapidly bureaucratizing, party organizations that dominate the political panorama and grant one access to a political career in the first place? In terms of organization and structure, as Michels's (1911) study had shown and Weber agreed, ${ }^{52}$ the developments within the political parties hardly differed from those taking place in the large capitalist firm or in the 'living machine' of state administration. If that was indeed the case, wouldn't parliamentary government be reduced then to the control of the higher ranks of the state bureaucracy by the higher ranks of party bureaucracies? Still, Weber insisted that there was a crucial difference in the processes of recruitment and selection between a purely administrative apparatus and that of a political party. While the highest positions in state administration are, in principle, attainable through formal mechanisms of career progressionbased on merit, antiquity or both - the persons aiming to become leaders of a political party have to prevail in unpredictable, highly volatile struggles for power, i.e. for followers and support both within and outside the party. In such struggles, aspiring politicians are supposed to develop their intrinsic, charismatic predispositions to leadership (Weber, 1994: 126, 160-161).

According to this perspective, to be sure, the rise of mass politics had no impact whatsoever on the elitist nature of politics. In fact, mass participation, occasioned by the extension of political rights to hitherto excluded groups, tended to strengthen rather than curb elitism. For the gap between the very few who were able to prevail in intra-party struggles, win large-scale electoral battles and assert their leadership in parliamentary 
debates, on the one hand, and their followers on the other hand, from base activists to the growing numbers of professional politicians earning their living from party work, became wider and ever more mediated by stern hierarchical structures. Paradoxically, thus, hierarchy was the price to pay for mass democracy: The extension of the base of support a politician needed to win over to be successful as a leader entailed an evenstricter organization of party 'machines' and a strong contraction at the top echelons. To Weber, all this came as no surprise and without a hint of exasperation, since, as he saw it, the historical successes of democracy had always been achieved, since ancient Greece, at the cost of substantial concessions to a Caesaristic principle of leadership:

For it is not the many-headed assembly of parliament as such that can 'govern' and 'make' policy. There is no question of this anywhere in the world, not even in England. The entire broad mass of the deputies functions only as a following of the leader or the small group of leaders who form the cabinet, and they obey them blindly as long as the leaders are successful. That is how things should be. The 'principle of the small number' (that is the superior political manoeuvrability of small leading groups) always rules political action. This element of 'Caesarism' is ineradicable (in mass states).

(Weber, 1994: 174) ${ }^{53}$

Weber's sharp analytic eye detected earlier than most that the advance of mass politics, by transforming the political parties into bureaucratized, hierarchical organizations geared towards success in a large-scale 'electoral battlefield' (Weber, 1994: 150), had obliterated the type of semiaristocratic politics (Honoratiorenpolitik) upon which the golden years of liberal parliamentarism had rested in Western Europe (and especially in Great Britain). This meant that parliaments could now no longer be conceived of as instances of discussion, persuasion and deliberation among independent personalities. Rather, they were turning into arenas of party political struggle, where deputies, regardless of the constitutional provisions that called for-and formally protected - their independence, voiced not personal convictions, but official party positions (Weber, 1994: 170). But if, indeed, most deputies had already been degraded to the status of a 'broad mass' which follows the leader blindly, did it still make sense to expect that new leaders, with a sense of independence and personal responsibility, would emerge from the ranks of parliament? Or should one look elsewhere for institutions capable of fostering political leadership in a context of pervasive bureaucratization? Weber's last months of intense political and journalistic activities, when the new democratic constitution for Germany was being drafted, indicate that the author was veering towards a pre-eminently plebiscitarian conception of democracy. 


\section{Revolutionary Unrest: From Parliamentary to Plebiscitarian Democracy}

In January 1919, Weber challenged the members of his student audience in Munich 'who share in the intoxication (Rausch) which this revolution signifies' to look ten years ahead. What did Weber see in that not so distant future? The arrival of 'an age of reaction,' of a long 'polar night of icy darkness and hardness' (Weber, 1994: 368). Revolutions, so it seems, were for him phenomena of a by-gone age of liberal-bourgeois emancipation. Now that the universalistic moral preaching of human rights had been reduced to formalistic legal positivism, that capitalism had discarded the religious substrate which had once infused it and that bureaucratic rule advanced irresistibly, revolutions were practically unthinkable. As the author submits in his sociology of domination, bureaucratic rule "makes "revolution," in the sense of the forceful creation of entirely new formations of authority, more and more impossible.' Indeed, '[t]he place of "revolutions" is under this process taken by coups d'état' (Weber, 1978: 989). The youth, so Weber, should indulge in no romantic delusions: The revolution that was sweeping through the streets of Munich could only arouse bitter reaction and thereby endanger the political acquis of the previous, bourgeois revolutionary age.

The students, however, were not the only ones who had to let go of illusions. Weber himself had to work his way through certain basic realities of post-war Germany that contradicted his earlier predictions. When, in September 1918, General Ludendorff called for a parliamentary government to negotiate peace with the Entente powers, the demand of parliamentarization, which the German monarchy had been able to contain for nearly half a century, was fulfilled from night to day, and far beyond the scope that Weber had deemed achievable only a few months before. Like most politically moderate intellectuals, Weber did not expect that the German monarchy would crumble like a deck of cards within two months, thus forcing him to concede that the course of historical events had overhauled his earlier reform proposals. Significantly, in a series of articles on the constitutional design of the post-war German state, Weber (1988: 99) starts by asking a question which history seemed to have already settled: Should Germany opt for a parliamentary monarchy or a republic? The real political struggle in those months opposed, in essence, those who wanted to promote the revolutionary councils of workers and soldiers that were emerging all over Germany and those who called for a speedy transition to a parliamentary democracy in the Western European tradition, through the election of a constituent national assembly. Weber stood, of course, on the side of the latter, and given the announcement of the abdication of Wilhelm II and his flight into exile on the 9th of November, this could only mean endorsing a republican form of government. In such a context, it comes somewhat as a surprise to see Weber 
(1988: 100) emphasize in a political tract, regardless of the concrete circumstances at hand, the abstract merits of parliamentary monarchy as a system of government.

Now, the sense of surprise is somewhat mitigated, if one takes into account that, in his wartime political writings, Weber (1994: 162) had held that the position of the German dynasties would come out of the war unchallenged. According to him, the monarchic head of state, far from being an institutional adornment, would play a decisive role as a force of moderation in the midst of intense party political antagonisms. Indeed, given the absence of a two-party system favouring the formation of stable parliamentary majorities, the role of the monarchy would be more prominent in Germany than it was in the UK. Weber realized perceptively that a two-party system akin to the Westminster model, with its liberal/ conservative divide, was untenable in mass democratic, modern industrial states. The economic cleavage between the bourgeoisie and the proletariat required parliamentary expression, and to this general condition of modern industrial society - which the author rightly thought would also come to transform the British two-party system - one had to add the persistence in Germany of a confessional divide which led the minority religion, Catholicism, to create its own political party. In such a context, at least four parties - conservatives, liberals, socialists and Catholicswould always coexist. The crown's moderating influence amidst all these parties would thus, so Weber (1994: 211) before the war ended as it did, be a key political factor.

Furthermore, it is not absurd to speculate that Weber was possibly more reluctant to let go of divine-right monarchy, and the traditionalized form of hereditary charisma upon which it rested, than he appeared to be. For sure, the republic would force the German bourgeoisie to shake off the 'will to impotence' it had developed under the protective shadow of the monarchy and finally take up its political tasks, which was a most welcome consequence (Weber, 1988: 106). However, in a situation as critical as that which Germany was facing, a lingering source of charismatic-traditional legitimacy could perhaps be useful in the process of consolidating a new political order. Weber's avowal of the republican state form seems to me less unambiguous than its phrasing suggests, and it is quite significant that he explicitly leaves the door open for a return of the monarchy through a constituent or plebiscitary decision (Weber, 1988: 107). At the dawn of the Weimar Republic, Max Weber was much more a Vernunftrepublikaner than a Gesinnungsrepublikaner-a republican for circumstantial, practical reasons, not by conviction. ${ }^{54}$

For Weber, the denouement of the war had in fact discredited not only the Prussian-German dynasty, but also the parliament and the parties. Weber's mistrust of political parties, and their 'succumb[ing] to bureaucratisation in much the same way as the state apparatus' (Weber, 1994: 228), featured prominently already in his earlier analyses of German 
politics, but therein he still considered that there was no alternative to party and parliamentary politics when it came to training and selecting political leaders. Such a verdict, however, is revised in the immediate aftermath of the elections to the constituent assembly, held in January 1919, which seem to have provided Weber a clear proof of the insufficiency of party rule. According to him, the places on the electoral slates that should have been taken by personalities with the potential to thrive as political leaders were instead given to 'shopminders' devoid of the calling for politics (Weber, 1994: 306). The system of proportional representation with closed lists, so Weber, contributed to this, and in the horizon stood a parliament of delegates of economic interests, of elected officials rather than elected leaders. Ultimately, thus, the November Revolution ended up reversing Weber's political priorities:

Previously, when we had an authoritarian state, one had to argue
for the power of the majority in parliament to be increased, so as
to raise, at long last, the importance and therefore the quality of
parliament. The situation today is that all constitutional proposals
have succumbed to crude, blind faith in the infallibility and omnip-
otence of the majority-of the majority in parliament, that is, not of
the people. We have gone to the opposite, but equally undemocratic
extreme.

(Weber, 1994: 307)

As Mommsen (1974b: 371-378) shows, in this reversal of the pre-war political priorities, Weber joined the mainstream liberal opinion, shared, among others, by Hugo Preuß, the jurist who was entrusted with the task of drafting the new constitution. Liberals, now that the monarchic head of state was missing, generally agreed that one had to tackle the danger of a so-called 'absolutism of parliament' (Parlamentsabsolutismus). They did so by emphasizing the Montesquieuian notion of the balance of powers. Robert Redslob's (1918) distinction between 'true' and 'false' forms of parliamentary government, still elaborated within the context of the monarchic constitution, provided them an important rhetorical tool. According to Redslob, the French system of the Third Republic, where the presidential head of state, elected by the two parliamentary chambers, was deprived of an immediate connection to the electorate, constituted a degeneration of parliamentary government. The English and the Belgian systems, by contrast, safeguarded the balance of powers through their crown/parliament dualism. 'True' parliamentary government requires, according to this perspective, two independent bearers of sovereignty to check each other's powers. For a republican Germany, such an analysis highlighted the need for a democratically elected president to stand on equal footing, as head of the executive, beside the legislative chamber. 
Weber, however, went beyond the horizon of the balance of powers when he argued, in a newspaper article on 'The President of the Reich' published in February 1919, that the true instance of democratic rule lies in the presidency rather than in parliament. In a telling analogy, he contends that just as the more intelligent monarchs had once voluntarily ceded their prerogatives to the emerging parliaments, these should now recognize what he terms as the 'Magna Charta of democracy':

A popularly elected president, as the head of the executive, of official patronage, and as the possessor of a delaying veto and the power to dissolve parliament and to consult the people, is the palladium of genuine democracy, which does not mean impotent self-abandonment to cliques but subordination to leaders one has chosen for oneself.

(Weber, 1994: 308)

Weber was very much aware of the implications of this plebiscitarian understanding of democracy in terms of the enormous rift that, under the guise of a closer relation between the two poles, opens up between leaders and followers, between top and bottom of the political system. To remain at the disposal of the leader as 'a useful apparatus,' the author argues, 'the following has to obey blindly' and undergo a process of 'spiritual proletarisation.' That is the price to pay, since, for him, 'the only choice lies between a leadership democracy with a "machine," on the one hand, and 'rule by the "professional politician"...who lacks precisely those inner, charismatic qualities which make a leader,' on the other hand (Weber, 1994: 351). ${ }^{55}$

\section{Weber's Foresight in Hindsight: An Overview}

Max Weber offered us arguably one of the first-and surely one of the most complete-immanent, self-reflective critiques of the modern age. His ambivalent narrative of modernity, which tells the story of the rise of Western rationalism and its multifarious, mostly non-intended consequences, is as distant from the moral optimism of Enlightenment thought, in both its earlier idealistic and later positivistic varieties, as it is from the cultural pessimism of anti-modern reactionaries and conservatives. The great achievement of the modern West lies, according to this narrative, in breaking free from the torpor of patriarchal rule and its magical cosmological projections, thus opening up for humankind an array of possibilities unknown to it within a horizon determined by strict ties to kin and soil. This liberation, however, harbours in itself the menace of a descent into newer, even sterner patterns of immobility, where the fetters of anonymous and impersonal authorities replace the shackles of personal loyalty. 
Weber's sociology of domination is where this dialectic of liberation and petrification, already announced in the climax of The Protestant Ethic and the Spirit of Capitalism, is more exhaustively explored. The broad transition from traditional to rational-legal forms of rule, which characterizes the Western historical development, plays out like an openended struggle rather than a predetermined route. The grounds upon which the validity of a domination rests cannot be fixed once and for all, and even the most efficient - that is to say, bureaucratic - varieties of rational-legal rule can in principle be revolutionized by the transformative power of charisma. In fact, however, the tension between bureaucracy and charisma is not one between even forces; as the former takes an ever-firmer hold on modern life, it might be that the latter, at some point, becomes wholly incapable of piercing through bureaucracy's rigid shell.

This tension between uneven forces, and their ambivalent consequences, reverberates through Weber's diagnosis of modern democracy. Modern democracy implies substantive as well as formal rationalization, it must establish the rule of abstract, impersonal law over against feudal privilege and royal arbitrariness, and therefore it necessitates a bureaucratic administration which operates strictly 'without regard to the person.' But the person is also, in Weber's account, the one and only source of innovation and change; only the extraordinary qualities of unique personalities can, according to the ideal type of charismatic authority, generate the enthusiasm and devotion needed to disrupt crystallized patterns of domination. Where bureaucratic rule tends to become pervasive, as it does in modern mass democracies, charismatic personalities encounter an inhospitable environment to the development and assertion of their extraordinary gifts. If they die out entirely as a consequence of bureaucratization, one might one day tragically find out that liberation from the authoritarian powers of tradition has redounded in subjection to an even more exacting, inescapable and immovable form of authority. Weber's quest to secure a place, in the institutional design of modern democracy, for political leaders with the potential to rise above and counteract bureaucratic rule must be read against this broad backdrop. Of course, it can be argued that to embed what is supposed to be extraordinary and revolutionary in the ordinary constitutional designs of modern democracies, be their accent more parliamentary or plebiscitary, is already to "de-charismatize" charisma (Kalyvas, 2008: 74). But what other options are there, if one does not want to let go of the achievements of rationallegal authority which bureaucratic rule, and only bureaucratic rule, can consolidate? If one does not intend to transcend modern democracy, but rather to save it from its self-destructive impulses by keeping rational democratic rule permeable to influxes of change and renewal which, according to Weber, can only stem from the intrinsic creative force of great personalities? 
Weber's diagnosis was undoubtedly prescient in emphasizing bureaucracy's threat to human freedom. The most perceptive analyses of twentieth-century totalitarianism take that diagnosis as a point of departure, even if they can hardly be content with it (Arendt, 1973: 175-221; ${ }^{56}$ Lefort, 1986: 89-121). And they cannot be content with it because the axiom, which Weber never places under scrutiny, that only the uniqueness of personality catalyses innovation and change prevents him from anticipating the paradoxical merger of intensified bureaucratic rule with an intense personality cult that characterizes the totalitarian experiences of the twentieth century. Irrespective of whether Hitler or Stalin should be interpreted as charismatic leaders in the Weberian sense of the term or not, ${ }^{57}$ in retrospect, it seems that Weber was too captivated by the ambivalences of bureaucracy to give due consideration to the equally ambivalent consequences of personal authority for modern democratic rule.

With the privilege of hindsight, it is impossible not to conclude that modern democracy is even more ambivalent than Weber took it to be at the dawn of the twentieth century. With his gaze absorbed by its characteristically modern paradoxes, he overlooked the phantoms of the pre-modern past that still haunted it and the ways in which these sought to fuse with the former-and thus he could not foresee the monstrous political bodies into which some modern societies, and especially his own, would degenerate in the very near future. Nevertheless, a highly sophisticated account of the tensions at the heart of modern democracy, which proceed from those at the very core of Western modernity, must be credited to him. Weber's diagnosis, indeed, casts its long shadow over the German-speaking interwar debate on the nature of modern democracy. In the next two chapters, we will see how Carl Schmitt and Hans Kelsen reinterpret its insights into divergent directions, drawing our attention to other dimensions of the modern democratic endeavour.

\section{Notes}

1 Emphasis added on 'belief' and elided on 'legitimacy.'

2 Emphasis elided.

3 Not without good reason, the University of California Press edition of Economy and Society adds Weber's most important wartime political tract (though omitting the final section on federalism and parliamentary government), 'Parliament and Government in a Reconstructed Germany,' as an appendix to the volume (Weber, 1978: 1381ff.).

4 Except for the double appearance in Weber (1994: 221), which together with the use of the phrase 'non-legitimate domination' (Weber, 1978: 1212ff.) in his analysis of the Western city, describing political formations, where dynastic legitimacy was altogether absent or seriously kept in strict check by patricians and/or plebeians, nevertheless shows that the terms were still associated with dynastic monarchism.

5 On Weber's anti-naturalistic stance, see Tenbruck (1959). 
6 These aspects will be elaborated upon in the next two chapters.

7 The text that serves as the conceptual introduction to Economy and Society, written in 1920, and upon which our brief exposition of Weber's sociological conception of legitimacy is based. This text indicates the direction that Weber's sociological project was taking at the time of his death, marked by a veering towards a behaviourist, empirical-positivist position.

8 Emphasis in the original.

9 I use the term in a broad sense to refer to the debates on epistemology and methods that were going on in German-speaking scholarly circles across the human and social sciences. In the Anglophone context, the expression is typically used to refer specifically to the controversy between the Austrian and the historical schools in economics over the status of axiomaticdeductive theory - a dispute which was part of, but can hardly be said to have exhausted, the turn of the century Methodenstreit landscape. Weber's early methodological writings can be found in the Gesammelte Aufsätze zur Wissenschaftslehre (Weber, 1951), now also in the Max Weber-Gesamtausgabe, I/7 (Weber, 2018), and in English translation by Hans Henrik Bruun (Weber, 2012), who has also discussed them thoroughly (Bruun, 2007). On Weber's position in the economic-theoretical Methodenstreit, which seems to find middle ground between the positions of Carl Menger and Gustav Schmoller, see Maclachlan (2017).

10 Emphasis elided on 'general cultural significance.' The alignment between the Archiv's research goals, as they are stated in the jointly signed 'Accompanying Remarks' (here quoted) to the first volume after the change in editorship, and the argument developed in Weber's essays on Protestantism and the spirit of modern capitalism - perhaps even more so than the points of contact with the programmatic essay on "The "Objectivity" of Knowledge in Social Science and Social Policy' published in the same volume-which would appear in the subsequent issues, has led many Weber scholars to believe that the 'Accompanying Remarks' had been drafted by Weber himself. However, Peter Ghosh (2010) has shown that these were actually drafted by Sombart and only slightly revised by Weber.

11 Emphasis in the original. Parsons's translation of the Protestant Ethic, which is based upon the version published in the Gesammelte Aufsätze zur Religionssoziologie, includes the 'Vorbemerkung' to that volume - a justified choice, in my view (irrespective of the violence Parsons's translations might have inflicted upon Weber's work elsewhere), since that text provides the broader perspective through which the essays on Protestantism must retrospectively be read, and which was not sufficiently clarified when Weber first published them.

12 Emphasis added. Let it be noted in passing that the intimate relationship Weber discerns between risky large-scale financial operations and state-led or state-sponsored military expeditions in the colonial peripheries should be emphasized in an age, like ours, where the predominance of financial, and the decay of industrial, capitalism in the West is too one-sidedly equated with an allegedly inexorable process of state retrenchment.

13 This is not to deny the connections that can fruitfully be established between Weber and Hegel in other respects, especially when it comes to the conceptualization of the bureaucracy. Avineri (1972: 160), indeed, suggests that Hegel already outlines 'a model of a bureaucracy almost identical with the Weberian ideal type.' However, in what is revealing of the way most post-WWII sociologists read Weber, Bendix (1977: 387-389, 487-493) simultaneously overstates Weber's proximity to Hegel's philosophy of history and wholly 
ignores the Nietzschean connections. Moreover, since in the very same passages this commentator acknowledges the importance of Burckhardt, he fails to note the obvious anti-Hegelian implications of Burckhardt's conception of cultural history. Also, Bendix's (1977: 387) suggestion that Weber's 'device of the ideal type' could be understood as a Hegelian 'procedure' must not be taken to imply that there is a discernible direct influence of Hegel on Weber's methodological theorizing. As Wagner and Härpfer (2015) show, the methodology of the ideal type comes from elsewhere. Furthermore, on Nietzsche's decisive influence, see Baier (1982), Eden (1984), Hennis (1987: 167-194) and Mommsen (1989: 26-27).

14 On the 'nature of historical irrationality,' see Weber (2012: 11 passim). The stricter sociological derivation of meaning Weber tried to arrive at in his later writings foundered because meaning, as it was actually meant by the participants of a given social interaction, is ultimately irretrievable; it is not contained in any objective sense in the (observable, measurable) empirical materials themselves. Weber as a champion and pioneer of a strictly empirical social science - an image one might paint of him if one focuses on a text like 'Basic Sociological Terms' (Weber, 1978: 3-62) - is, as we have noted earlier, highly problematic. If, however, one takes his broader historical perspective into account, one realizes that what he posits as the task of the social - or better yet, cultural — sciences is not so much the empirical discovery of meaning, but rather its creation. Following this line of reasoning, what stands in between the cultural scientist and arbitrary imputations of meaning is merely his or her duty, as a scholar, to abide by the rules of rational (i.e. logical) discourse in the connection of concepts and materials-these rules being themselves products of Western rationalism.

15 Richard Baxter (1615-1691) is the Puritan minister on whose writings Weber focuses especially in the second part of The Protestant Ethic [note by PM].

16 Parsons's canonical translation of The Protestant Ethic is today consensually viewed by Weber scholars as highly problematic (Ghosh, 1994). In my view, the omission of the clear reference to Nietzsche is even more lamentable than the rendition of what became of Baxter's 'light cloak' as 'an iron cage.' To be sure, as Baehr (2001) rightly suggests, 'a shell as hard as steel' would be a more faithful translation of ein stahlhartes Gehäuse, since it would preserve the ambivalent subtleties of the Weberian metaphor. The Gehäuse is hard, of course, but it is made of steel (Stahl), which, unlike the element of the Periodic Table "iron" (Fe), is a product of human fabrication and, thus, potentially flexible. In addition, 'shell' captures the meaning of Gehäuse more precisely than 'cage,' for while the latter conveys the idea that humanity, with its 'powers otherwise intact,' is incarcerated by the rise of Western capitalism as an arguably exogenous phenomenon, the former, closer to the argument that Weber lays out, 'suggests that modern capitalism has created a new kind of being' (Baehr, 2001: 153 (emphasis in the original)). However, as Baehr (2001: 168-169) himself must admit, not only is the 'iron cage' 'a great coinage in its own right,' but it also captures the haunting fears of ossification and petrification that are at the very heart of Weber's story of modernity. The omission of the Nietzschean connection, in turn, is particularly deplorable, because the passage constitutes one of the few instances where Weber, who otherwise was more keen on hiding than on revealing the sources of his inspiration, indicates upon the shoulders of which giants his vision stood.

17 Interestingly enough, Michels's (1911: 362) law, in the original, is also not 'iron,' but rather 'bronze' (das eherne Gesetz der Oligarchie). In this case, 
however, the translation captures with precision the meaning, for Michels does indeed intend to convey the idea that the formation of oligarchies is an unbending, "elemental" law of mass organizations. In his Italian writings, Michels does indeed use the expression "iron law" (legge ferrea) of oligarchy.

18 Max Weber to Hermann Graf Keyserling, 21.06.1911 (emphasis in the original): "Aber wir danken den "Prinzipien von 89" - deren Kindlichkeit unser Lächeln, deren pedantische Vergewaltigungen der Realität unsren Protest erregen - Dinge, ohne Welche das Leben nicht mehr ertragen würde.'

19 Emphasis in the original.

20 For an engaging discussion of "liquids" and "solids" in the context of a more recent enquiry on modernity, see Bauman (2000: 1-15), who nevertheless does not explore in depth the contrast between the Marxian and the Weberian metaphors. In fact, Weber emerges there rather in connection with the 'melting the solids' perspective, and it is only later on in the book that the author re-introduces him as an exponent of the age of 'heavy capitalism' (Bauman, 2000: 4, 59-60). The fact that Weber can just as easily be used in both connections testifies to the 'antinomical' (Mommsen, 1989: 24) quality of his thought. Furthermore, if one considers the latest developments in the modern condition that Bauman surveys - the growing de-materialization of social relations in the digital age, the concomitant contraction of space and time, the triumph of finance over industry and so on-the Marxian stress on fluidity certainly appears to be heuristically more useful than the Weberian fears of impending ossification.

21 The fragments on which he was working at the time of his death are published in a volume titled Sociology of the State (Staatssoziologie), edited by Johannes Winckelmann (Weber, 2011).

22 The revision of the essay for the GARS, upon which Parsons' translation is based, introduced a minor correction to this passage. While the 1904/1905 text speaks of "Chinese" petrification' (chinesische Versteinerung), the 1920 revision changes it to 'mechanized petrification' (mechanisierte Versteinerung), a correction which, to be sure, makes the suggestion of the three ideal types much clearer. For while a 'Chinese petrification' compares and connects the rigidity of the iron or steely cage of modernity with that of traditional Oriental despotism, 'mechanized petrification' emphasizes the wholly new forms of rational-legal rigidity to which both the 'lifeless' machines of industry and the 'living' ones of bureaucracy contributed (Weber, 1904/1905: 109; 1947: 204).

23 Ronald Speirs' 1992 translation suggests the duality by distinguishing between 'profession' and 'vocation.' However, given its current usage in the English language, I do not think that the word 'vocation' conveys with enough intensity the intrinsically personal and at the same time spiritual nature of the $R u f$ that constitutes the radix of Beruf. Therefore, if I were to translate the title to English, I would render it as Politics as a Profession and as a Calling.

24 See also there the long footnote on the semantics of Beruf in ancient and modern languages.

25 See the recollections of Karl Löwith, student in Munich at the time, who, concerning the first lecture, writes that 'his [Weber's] sentences condensed the experience and knowledge of an entire life.' As regards the lecture on politics, he notes that it did not possess 'the same captivating momentum.' These passages from Löwith's report, written in exile, on his life in Germany before and after 1933 are quoted in Weber (1992b: 14-15).

26 Just three weeks after Weber's lecture, Eisner was murdered by a student connected with the nationalist far-right. 
27 Emphasis in the original.

28 Emphasis elided.

29 Ultimately, as Tyrell (1994) argues, Weber's sociology has no use for the grand concept of society. His is much more a science of the contingent, yet interrelated, actions of individuals and groups, and the patterns they form, than of rigid social structures. See, in relation to this, our analysis below of Weber's understanding of power.

30 Emphasis elided.

31 In any case, it would be exaggerated to conceive of Weberian domination as a perfectly stable relationship of submission of the ruled to the rulers. Elsewhere, the author defines domination as 'the probability that a command will be obeyed' (Weber, 1978: 53 (emphasis elided)). It remains unsure, according to that definition, whether the rulers will be obeyed by all the intended recipients of their commands, but it is very likely that obedience consolidates as a norm or rule. However, the options of the ruled shrink significantly relative to those of actors involved in fluid relations of power: There is still a choice between obedience and disobedience, but to reverse the asymmetrical relationship to the rulers is not an immediate option and would require an exceptional transformative effort.

32 Emphasis in the original. The English word "calling" would be a better translation of Beruf in this instance.

33 For every traditional rule can in principle be brought back to a charismatic origin (a victorious war leader, a community-founding religious prophet, etc.), while every transformative charismatic movement asserts itself necessarily against some pre-existing form of traditional rule.

34 For Weber, traditional authority is based on the nexus between paternal power and filial piety, whereas in rational-legal forms of authority 'obedience is owed to the legally established impersonal order' (Weber, 1978: 215).

35 For fruitful reflections on the centrality of charisma in Weber's sociology of domination, see Mommsen (1974a: 128) and Hanke (2001: 32).

36 According to Weber (1978: 964), the decisive push towards the bureaucratization of the Catholic Church took place in the end of the thirteenth century-i.e. in the aftermath of the assertion of papal plenitudo potestatis by Innocent III.

37 Löwith (1993: 63) goes to the heart of the matter when he writes that '[e]ven the approach from the standpoint of the sociology of religion aims in the end to be nothing less than a contribution to the sociology of rationalism itself.'

38 Emphasis added.

39 Max Weber to Mina Tobler, 24.08.1915: 'der unendlich ahnungslose Kinderglaube an die Macht des Vernünftigen.' The remark occurs in the context of a discussion on Plato.

40 Weber's essay on the rational and sociological foundations of music was probably completed in late 1912 or early 1913, but like so many of his works, it was only posthumously published. It also circulated in some editions of Economy and Society as an appendix.

41 Emphasis elided.

42 Furthermore, Radkau also suggests that there might be an indirect influence, mediated by Weber's brother Alfred, who taught in Prague, of Kafka on his understanding and depiction of the bureaucracy.

43 Most notably, he was involved as an advisor in the first discussions concerning the drafting of the Weimar constitution, which took place at the Ministry of the Interior shortly after the war ended.

44 Max Weber to Hermann Baumgarten: 'Der Grundfehler ist doch wohl das Danaergeschenk des Bismarckschen Cäsarismus: das allgemeine 
Stimmrecht, der reinste Mord für die Gleichberechtigung aller im wahren Sinne des Wortes.'

45 For a discussion of the lecture which lays emphasis on the social Darwinist undertones, see Aron (1971: 90-94).

46 See e.g. Windelband (1916: 7-13). The fate of neo-Kantianism was to a large extent sealed, quite irrespective of its many intrinsic philosophical problems, by the war apology of old professors in Heidelberg and Marburg (Beiser, 2013). An apology which was self-evidently contradictory, for Kant, who recognized no transcendent sources of validity in either science or ethics, is probably the last thinker whose ideas one can use to justify the sacrifice of human life for the sake of Reich and Kaiser.

47 In this case, both the use of italics and quotation marks as in the original German edition. Weber, as anyone familiar with his writings knows, had a pronounced tendency to use quotation marks, even if not always consistently, for various purposes besides citation (irony, distance, emphasis, etc.). Translators have not always paid due attention to this. For instance, in the heading of this fragment on nationalism, the 1978 translation of Economy and Society elides the quotation marks of the original German edition.

48 Emphasis elided.

49 According to Edith Hanke, the text must have been written between the summer of 1917 and January 1919 (Weber, 2005: 722-723).

50 'Dieses Verhältnis kann indessen leicht dahin umgedeutet werden: daß die freie Anerkennung durch die Beherrschten ihrerseits die Voraussetzung der Legitimität und ihre Grundlage sei (demokratische Legitimität).'

51 Emphasis elided. It should be noted here that sociologists after Weber have often evaluated the effects of the rise of state bureaucracy on the political class in quite a different light. For instance, analysing post-Second World War developments in the U. S., Mills (1956: 295) sees in the 'absence of a genuine civil service' one of the main reasons for the decline of the political elite in comparison with the rising military and corporate hierarchies.

52 According to Weber (1978: 951), '[a] political party, after all, exists for the very purpose of fighting for domination in the specific sense, and it thus necessarily tends toward a strict hierarchical structure, however carefully it may be trying to hide this fact.'

53 Emphasis elided throughout except on '[t]hat is how things should be.' Furthermore, on the 'law of the small number' and the Caesaristic tendencies of democracy, see Weber (1978: 952, 961-962).

54 Let us also bear in mind that, as Mommsen (1974b: 326) points out, Weber did not initially join the left-liberal German Democratic Party (DDP) precisely because of its unequivocal stance on the republican form of the new regime.

55 The English translation does not convey the wit of the German punBerufspolitiker ohne Beruf-which exploits the double meaning of the word.

56 Even if here Arendt does not mention Weber once and deals with a topic - the synthesis of race and bureaucracy in the age of imperialism - which he did not consider, the fundamental Weberian understanding of the bureaucracy is, I think, presupposed in the background.

57 Arendt (1973: 361, fn. 57) thinks not, thus disagreeing with Weber scholars such as Gerth (1940) and Mommsen (1974b: 435-437). I would say that in the pre-eminently value-free sense that the concept of charisma has in Weber's sociology, it would be applicable to Hitler and to an analysis of Nazi rule, which of course does not mean that Hitler would be in any sense close to the specific type of responsible charismatic leader Weber has in mind in his political writings. 


\section{References}

Arendt, H. (1973). The Origins of Totalitarianism, San Diego: Harcourt Brace.

Aron, R. (1971). 'Max Weber and Power-Politics,' in O. Stammer (ed.), Max Weber and Sociology Today, New York: Harper \& Row, pp. 83-100.

Avineri, S. (1972). Hegel's Theory of the Modern State, Cambridge: Cambridge University Press.

Baehr, P. (2001). 'The "Iron Cage" and the "Shell as Hard as Steel": Parsons, Weber, and the Stahlhartes Gehäuse Metaphor in The Protestant Ethic and the Spirit of Capitalism,' History and Theory, Vol. 40, No. 2, pp. 153-169.

Baier, H. (1982). 'Die Gesellschaft - ein langer Schatten des toten Gottes. Friedrich Nietzsche und die Entstehung der Soziologie aus dem Geiste der Décadence,' Nietzsche-Studien, Vol. 10, No. 1, pp. 6-33.

Bauman, Z. (2000). Liquid Modernity, Cambridge: Polity Press.

Beiser, F. C. (2013). 'Weimar Philosophy and the Fate of Neo-Kantianism,' in P. E. Gordon and J. P. McCormick (eds), Weimar Thought: A Contested Legacy, Princeton: Princeton University Press, pp. 115-132.

Bellamy, R. (1992). 'Liberalism and Nationalism in the Thought of Max Weber,' History of European Ideas, Vol. 14, No. 4, pp. 499-507.

Bendix, R. (1977). Max Weber: An Intellectual Portrait, Berkeley: University of California Press.

Bruun, H. H. (2007). Science, Values and Politics in Max Weber's Methodology, new ex. ed., Aldershot: Ashgate.

Dogan, M. (2010). 'La légitimité politique: nouveauté des critères, anachronisme des théories classiques,' Revue Internationale des Sciences Sociales, Vol. LX, No. 2, pp. 21-39.

Eden, R. (1984). Political Leadership and Nihilism: A Study of Weber and Nietzsche, Gainesville: University Presses of Florida.

Freeden, M. (1998). 'Is Nationalism a Distinct Ideology?,' Political Studies, Vol. 46, pp. 748-765.

Friedrich, C. J. (1963). Man and his Government: An Empirical Theory of Politics, New York: McGraw-Hill.

Gerth, H. (1940). 'The Nazi Party: Its Leadership and Composition,' American Journal of Sociology, Vol. 45, No. 4, pp. 517-541.

Ghosh, P. (1994). 'Some Problems with Talcott Parsons,' Archives Européennes de Sociologie, Vol. 35, No. 1, pp. 104-123.

Ghosh, P. (2010). 'Max Weber, Werner Sombart and the Archiv für Sozialwissenschaft: The authorship of the 'Geleitwort' (1904),' History of European Ideas, Vol. 36, No. 1, pp. 71-100.

Grafstein, R. (1981). 'The Failure of Weber's Conception of Legitimacy: Its Causes and Implications,' The Journal of Politics, Vol. 43, No. 2, pp. 456-472.

Habermas, J. (1988). Legitimation Crisis, trans. T. McCarthy, Cambridge: Polity.

Hanke, E. (2001). 'Max Webers „Herrschaftssoziologie.“ Eine werkgeschichtliche Studie,' in E. Hanke and W. J. Mommsen (eds), Max Webers Herrschaftssoziologie. Studien zur Entstehung und Wirkung, Tübingen: Mohr Siebeck, pp. 19-46.

Hennis, W. (1987). Max Webers Fragestellung. Studien zur Biographie des Werks, Tübingen: Mohr Siebeck.

Jones, E. (1908). 'Rationalization in Every-day Life,' The Journal of Abnormal Psychology, Vol. 3, No. 3, pp. 161-169. 
Kalyvas, A. (2008). Democracy and the Politics of the Extraordinary: Max Weber, Carl Schmitt, and Hannah Arendt, Cambridge: Cambridge University Press.

Kelsen, H. (1921). 'Der Staatsbegriff der „verstehenden Soziologie,"' Zeitschrift für Volkswirtschaft und Sozialpolitik, Vol. 1, pp. 104-119.

Lefort, C. (1986). The Political Forms of Modern Society: Bureaucracy, Democracy, Totalitarianism, ed. J. B. Thompson, Cambridge, MA: MIT Press.

Löwith, K. (1993). Max Weber and Karl Marx, London: Routledge.

Maclachlan, F. (2017). 'Max Weber within the Methodenstreit,' Cambridge Journal of Economics, Vol. 41, No. 4, pp. 1161-1175.

Marx, K. (1973). Grundrisse: Foundations of the Critique of Political Economy, trans. M. Nicolaus, Harmondsworth: Penguin.

Marx, K. and F. Engels (1976). Collected Works, Vol. 6, trans. J. Cohen et al., London: Lawrence \& Wishart.

Michels, R. (1911). Zur Soziologie des Parteiwesens in der modernen Demokratie. Untersuchungen über die oligarchischen Tendenzen des Gruppenlebens, Leipzig: Werner Klinkhardt.

Michels, R. (1915). Political Parties: A Sociological Study of the Oligarchical Tendencies of Modern Democracy, trans. E. Paul and C. Paul, New York: Hearst's International Library.

Mills, C. W. (1956). The Power Elite, Oxford: Oxford University Press.

Mommsen, W. J. (1974a). Max Weber. Gesellschaft, Politik und Geschichte, Frankfurt am Main: Suhrkamp.

Mommsen, W. J. (1974b). Max Weber und die deutsche Politik 1890-1920, 2nd ex. ed., Tübingen: Mohr Siebeck.

Mommsen, W. J. (1989). The Political and Social Theory of Max Weber: Collected Essays, Cambridge: Polity.

Oakes, G. (1988). Weber and Rickert: Concept Formation in the Cultural Sciences, Cambridge, MA: MIT Press.

Palonen, K. (2001). 'Was Max Weber a 'Nationalist'? A Study in the Rhetoric of Conceptual Change,' Max Weber Studies, Vol. 1, No. 2, pp. 196-214.

Palonen, K. (2002). Eine Lobrede für Politiker. Ein Kommentar zu Max Webers „Politik als Beruf," Wiesbaden: Springer.

Peukert, D. J. K. (1989). Max Webers Diagnose der Moderne, Göttingen: Vandenhoeck \& Ruprecht.

Radkau, J. (2013). Max Weber. Die Leidenschaft des Denkens, Munich: Carl Hanser.

Redslob, R. (1918). Die parlamentarische Regierung in ihrer wahren und in ihrer unechten Form. Eine vergleichende Studie über die Verfassungen von England, Belgien, Ungarn, Schweden und Frankreich, Tübingen: Mohr Siebeck.

Scaff, L. A. (1989). Fleeing the Iron Cage: Culture, Politics, and Modernity in the Thought of Max Weber, Berkeley: University of California Press.

Schluchter, W. (1981). The Rise of Western Rationalism: Max Weber's Developmental History, trans. G. Roth, Berkeley: University of California Press.

Schmitt, C. (2009). Politische Theologie. Vier Kapitel zur Lehre von der Souveränität, Berlin: Duncker \& Humblot.

Smith, D. N. (1998). 'Faith, Reason, and Charisma: Rudolf Sohm, Max Weber, and the Theology of Grace,' Sociological Inquiry, Vol. 68, No. 1, pp. 32-60.

Sohm, R. (1892). Kirchenrecht, Leipzig: Duncker \& Humblot.

Strauss, L. (1953). Natural Right and History, Chicago: Chicago University Press. 
Sukale, M. (2002). Max Weber. Leidenschaft und Disziplin, Tübingen: Mohr Siebeck.

Tenbruck, F. (1959). 'Die Genesis der Methodologie Max Webers,' Kölner Zeitschrift für Soziologie und Sozialpsychologie, Vol. 11, No. 4, pp. 573-630.

Tyrell, H. (1994). 'Max Webers Soziologie - eine Soziologie ohne "Gesellschaft,", in G. Wagner and H. Zipprian (eds), Max Webers Wissenschaftslehre, Frankfurt am Main: Suhrkamp, pp. 390-414.

Voegelin, E. (1987). The New Science of Politics: An Introduction, Chicago: University of Chicago Press.

Wagner, G. and C. Härpfer (2015). 'Neo-Kantianism and the Social Sciences: From Rickert to Weber,' in N. d. Warren and A. Staiti (eds), New Approaches to Neo-Kantianism, Cambridge: Cambridge University Press, pp. 171-185.

Weber, M. (1904/1905). 'Die protestantische Ethik und der „Geist“ des Kapitalismus,' Archiv für Sozialwissenschaft und Sozialpolitik, Vols 2-3, pp. 1-54 (2), 1-110 (3).

Weber, M. (1921). Die rationalen und soziologischen Grundlagen der Musik, Munich: DMV.

Weber, M. (1922). Wirtschaft und Gesellschaft, Tübingen: Mohr Siebeck.

Weber, M. (1936). Jugendbriefe, ed. Marianne Weber, Tübingen: Mohr Siebeck.

Weber, M. (1946). From Max Weber: Essays in Sociology, trans. and ed. H. H. Gerth and C. W. Mills, New York: Oxford University Press.

Weber, M. (1947). Gesammelte Aufsätze zur Religionssoziologie, 4th ed., Tübingen: Mohr Siebeck.

Weber, M. (1951). Gesammelte Aufsätze zur Wissenschaftslehre, 2nd ed., Tübingen: Mohr Siebeck.

Weber, M. (1958). The Religion of India: The Sociology of Hinduism and Buddhism, trans. and ed. H. H. Gerth and D. Martindale, Glencoe: Free Press.

Weber, M. (1967). Ancient Judaism, trans. and ed. H. H. Gerth and D. Martindale, New York: Free Press.

Weber, M. (1968). The Religion of China: Confucianism and Taoism, trans. and ed. H. H. Gerth, New York: Free Press.

Weber, M. (1971). Gesammelte politische Schriften, 3rd ed., ed. J. Winckelmann, Tübingen: Mohr Siebeck.

Weber, M. (1978). Economy and Society, ed. G. Roth and C. Wittich, Berkeley: University of California Press.

Weber, M. (1988). Gesamtausgabe, Band I/16: Zur Neuordnung Deutschlands, ed. W. J. Mommsen, Tübingen: Mohr Siebeck.

Weber, M. (1992a). The Protestant Ethic and the Spirit of Capitalism, trans. T. Parsons, London: Routledge.

Weber, M. (1992b). Gesamtausgabe, Band I/17: Wissenschaft als Beruf (1917/1919), Politik als Beruf (1919), ed. W. J. Mommsen and W. Schluchter, Tübingen: Mohr Siebeck.

Weber, M. (1994). Political Writings, ed. P. Lassman and R. Speirs, Cambridge: Cambridge University Press.

Weber, M. (1998). Gesamtausgabe, Band II/7, 1. Halbband: Briefe 1911-1912, ed. M. R. Lepsius and W. J. Mommsen, Tübingen: Mohr Siebeck.

Weber, M. (2005). Gesamtausgabe, Band I/22-4: Wirtschaft und Gesellschaft: Herrschaft, ed. E. Hanke, Tübingen: Mohr Siebeck.

Weber, M. (2008). Gesamtausgabe, Band II/9: Briefe 1915-1917, ed. G. Krumeich and M. R. Lepsius, Tübingen: Mohr Siebeck. 


\section{Max Weber's Diagnosis of Modernity}

Weber, M. (2011). Staatssoziologie, 3rd ed., ed. J. Winckelmann, Berlin: Duncker \& Humblot.

Weber, M. (2012). Collected Methodological Writings, ed. H. H. Bruun and S. Whimster, Abingdon: Routledge.

Weber, M. (2018). Gesamtausgabe, Band I/7: Zur Logik und Methodik der Sozialwissenschaften, ed. G. Wagner, Tübingen: Mohr Siebeck.

Weichlein, S. (2007). 'Max Weber, der moderne Staat und die Nation,' in A. Anter and S. Breuer (eds), Max Webers Staatssoziologie, Baden-Baden: Nomos, pp. 103-116.

Windelband, W. (1916). Geschichtsphilosophie. Eine Kriegsvorlesung, Berlin: Reuther \& Reichard. 


\section{The Neo-Authoritarian Populism of Carl Schmitt}

In 1964, a young professor took the word in the 15th congress of the German Sociological Association, held in Heidelberg to celebrate the centenary of Max Weber's birth, to say that German scholars, contrary to their Anglo-American colleagues, could not afford the luxury of forgetting that Carl Schmitt, legal adviser to the Nazis, had been a 'legitimate pupil' of Weber. The young professor was called Jürgen Habermas and his statement was meant to be polemical rather than historically accurate. In a note added to the conference proceedings, Habermas would have it revised, substituting 'natural son' for 'legitimate pupil' (see Stammer, 1971: 66). This revision, leaving the idea of bastardy hanging in the air, is hardly any less polemical, but it is surely more faithful to the historical record. Even if Schmitt attended Weber's lectures in Munich and took part there in his colloquium for young academic staff (Mehring, 2009: 118), he was never a member of Weber's closest circle of younger, promising scholars. Unlike his arguably more 'legitimate' disciples, he was never invited to Weber's famous Heidelberg salon, and he certainly did not belong to the politically and intellectually heterogeneous group of thinkers - such as Karl Jaspers, Carl J. Friedrich, Georg Lukács and Robert Michels, among many others - who developed Weber's legacy in different directions. Still, Habermas's point cannot be dismissed by a mere reference to historical facts, for it is far from absurd, even if it misses the broader picture, to see in Schmitt's critique of parliamentary democracy a radical variant of Weber's elitist, and in its latest version Caesaristic-plebiscitarian, conception of democratic politics (Mommsen, 1974: 408-413). These similarities in matters of political analysis, which are genuine rather than a fabricated legend (pace Villa, 2013), must nevertheless be interpreted in light of fundamentally different views concerning the nature and the challenges of modern politics (Magalhães, 2016). While, for Weber, the transition to the modern age was marked by the replacement, with rather ambivalent consequences, of personal - traditional and charismatic - forms of authority by impersonal, rational-legal ones, Schmitt insists on the ineradicably personal nature of political rule also in the modern state. Furthermore, in contrast to Weber's intrinsically tensional understanding of modern democratic

DOI: $10.4324 / 9781315157566-2$ 
rule as an anti-authoritarian reinterpretation of charisma, Schmitt offers a distinctly authoritarian reading of modern democracy. This chapter maps the development of such interpretation in Schmitt's Weimar-era writings.

Now, to say that Schmitt's thinking about modern politics in general, and modern democracy in particular, is less ridden by tensions and antinomies than Weber's does not mean that it is any less complex, or less prone to divergent interpretations. A brief look at the secondary literature suffices to prove this point. Even the more obvious characterization of Schmitt as 'the enemy of liberalism' (Lilla, 1997) is not consensually accepted. Indeed, already in 1932, Leo Strauss, in his thought-provoking notes on The Concept of the Political, remarked that Schmitt's critique of liberalism was ultimately an immanent one, which did not succeed 'in gaining a horizon beyond liberalism' (Strauss, 1988: 119). One year later, from the opposite side of the political spectrum, Hermann Heller (2015) interpreted a speech delivered by Schmitt (1998) to an audience of business leaders 'as the theoretical manifestation of the authoritarian turn of liberal thought' (Bonefeld, 2017: 748). Moreover, even if one does accept the standard narrative of Schmitt as, in essence, an anti-liberal thinker, controversy persists concerning the basic underlying motives behind his critique of liberalism. Should he be interpreted as a Catholic thinker (Wacker, 1994), an obscurantist theologian (Meier, 2004), a secular "conservative revolutionary" (Mohler, 1989) or ultimately a nihilist thinker (Löwith, 1984)? To the extent that we are less interested here in a comprehensive judgement on Carl Schmitt's thought than we are in his concept of modern democracy, it is not our primary concern to take sides in these controversies. In any case, to lay emphasis on Schmitt's views on democracy undoubtedly brings to the fore the secular rather than the allegedly religious dimensions of his thought, the modern political theorist rather than the arcane political theologian. In fact, we contend that hisresolutely anti-liberal - theory of democracy is (1) neo-authoritarian, in the sense that it formulates the necessity of personal rule in modern democratic polities without recourse to traditional conceptions of authority and legitimacy, and (2) populist, in that it sees the "the people," understood as a homogenous collective subject, as the entity which at one and the same time results from the exercise of neo-authoritarian rule and constitutes the ultimate source of its validity.

The chapter is structured in three main sections. In the first one, we discuss Schmitt's early works, written before and during the First War, to delineate his basic intellectual orientation at the dawn of the Weimar Republic. Subsequently, we reconstruct Schmitt's neo-authoritarian philosophy of the modern state as it emerges from his reflections on the concepts of dictatorship and sovereignty in the early 1920s. The third section focuses on Schmitt's conception of "the people" as the foundation of modern democratic rule, and on how it articulates with his decisionistic, 
neo-authoritarian vision. The last section concludes with a critical reevaluation of his neo-authoritarian populism.

\section{Schmitt's Early Years: Stages of a Jurist's Devotion to the State}

\section{Neo-Kantianism, Neo-Hegelianism and "Formal" Catholicism}

Carl Schmitt grew up in a double sense as an outsider in the Wilhelmine Empire. On the one hand, born in the small Westphalian town of Plettenberg to petty bourgeois parents, he belonged by socio-geographical origin to a silent majority of Germans, with roots in a semi-rural patchwork of small towns and villages, who experienced with distrust the processes of industrialization and urbanization that pushed them to the big cities. On the other hand, as a Catholic whose parents came from the Moselle valley, he was the member of a confessional minority whose political selfawareness evolved rapidly in response to Bismarck's Kulturkampf during the second half of the nineteenth century. Unlike Max Weber, Schmitt had thus very little in common with the ruling Prussian-Protestant elites of the German Reich in which he was born. Still, his option, as a humanistically gifted student, for an academic career, instead of priesthood, expressed the intention to overcome such an outsider status and accommodate to mainstream Wilhelmine society. In addition, it also opened the door for upward social mobility. Schmitt studied law in Berlin, Munich and Strassburg, where he graduated in 1910. Before the outbreak of the First World War, he had already published three books and several articles, establishing himself as a promising and ambitious young scholar.

The absence of the topic of democracy from these early writings is hardly surprising. No one aspiring to a career in German law faculties at the time would be wise to publish on such a heated political theme. This is not to say, however, that these early works are irrelevant for our understanding of Schmitt's thought on the subject. Indeed, the author himself sees in Gesetz und Urteil (1912a), a monograph on the relationship between judicial rulings and written legal statutes, the origin of his theory of decisionism, which he would develop roughly one decade later when dealing with the problems of dictatorship and sovereignty. ${ }^{1}$ However, from the perspective of political theory, his work on Der Wert des Staates und die Bedeutung des Einzelnen (1914) deserves a more careful analysis.

The book, in fact, deals with a crucial topic in modern political theory: the relationship between the state and the individual. As the title suggests, priority is accorded to the value of the former rather than to the significance of the latter. If this conclusion is far from surprising in the authoritarian context of the Wilhelmine Reich, it also fits well into the sustained anti-liberal pattern of Schmitt's thought. However, the argument developed by the 
author to arrive at such a conclusion shows him still struggling with the political and intellectual foundations of his thought. Commentators generally agree that Der Wert des Staates und die Bedeutung des Einzelnen is the work where a neo-Kantian influence is most clearly discernible in the Schmittian æuvre. Quoting extensively from it, his first biographer argues that 'neo-Kantianism offered Schmitt a means of synthesizing the dichotomous sympathies he felt as a German nationalist and as a Catholic' (Bendersky, 1983: 10). To be sure, neo-Kantianism had a transitional position in German academic philosophy, between the golden age of idealism and the emergence of positivism (Köhnke, 1986), which made it a convenient point d'appui for various attempts to reconcile contradictory intellectual currents and political commitments. The professional philosophers were, in essence, preoccupied that the rise of the natural sciences would lead to the obsolescence of their academic discipline. They hoped to avoid this fate by rethinking philosophy - in the image of Kant's Critique of Pure Reason, which they viewed as his greatest achievement - as an activity primarily concerned with the critical enquiry into the conditions of possibility and validity of knowledge, especially in the domain of the rising, highly specialized natural sciences, but also in ethics, law and aesthetics. Furthermore, quite apart from strictly philosophical questions, the neo-Kantian professors, given their insertion into the Imperial university system, also faced concrete political dilemmas, which ultimately were not very different from the tension between German nationalism and Catholicism that Bendersky identified in the young Carl Schmitt, and to which neo-Kantianism supposedly provided the means for a synthesis. Particularly after the outbreak of the Great War, the neoKantian professors were at pains to reconcile the progressive cosmopolitan outlook of Kant's philosophy - which some of them had actually developed in the direction of an ethical socialism (Holzhey, 1994) - with their official duty, as functionaries of the Reich, to contribute to the nationalist propaganda effort. Since Kant, as Gellner (1983: 132) forcefully put it, 'is the very last person whose vision could be credited with having contributed to nationalism,' this synthesis was not particularly successful and could only be achieved at the cost of great intellectual sacrifice. ${ }^{2}$ It seems thus doubtful, in light of this broader picture, that by itself neoKantianism could have provided Schmitt the means to bridge the gap between the divergent political and intellectual sympathies of his formative years. My interpretation of Der Wert des Staates, which indeed constitutes an attempt at synthesis, is instead that it tries to combine the three main vectors in Schmitt's early work: neo-Kantianism as the semiofficial philosophical school in Imperial Germany on the eve of the First War, a neo-Hegelian valorization of the state and a "formal," rather than substantive, Catholicism. ${ }^{3}$

The first chapter of Der Wert des Staates could scarcely be more neo-Kantian in its reasoning, with Schmitt arguing that there is an unbridgeable gap between the 'two worlds' of law and power, normativity 
and facticity, Sollen and Sein. Astonishingly, perhaps, for those familiar with the decisionistic doctrine he would coin a few years later, the author posits not only that those two spheres constitute self-contained systems of meaning, but also that the sphere of norms takes logical precedence over the sphere of facts, in the sense that only ideal, supra-empirical law can 'ground' factual power (Schmitt, 1914: 20-24). However, in what one could describe as a strange Hegelian-Catholic twist, the state emerges in the second chapter as the crucial entity, whose task is to mediate between the two autonomous, unconflatable realms and, more specifically, to supply concrete form to the normative ideal. This means that the state should be understood in terms of the normative ideal it is supposed to realize, rather than having its definition derived, as sociologists would have it, from its manifold manifestations in empirical reality by way of 'inductive' methods. The state is, according to Schmitt, a normative value-concept that aims at impregnating earthly reality with an idea, and he sees no better model for this than the self-understanding of the Catholic Church as civitas Dei, where divine law acquires a concrete institutional form (Schmitt, 1914: 44-46). Here and elsewhere (Schmitt, 1917/1918; 2008), his Catholicism is essentially "formal"; his main interests are neither the dogmas of faith nor the ethical and social teachings of the Church, but rather its institutional architecture and how it sought to achieve a continuous representation of the divine on earth, after Christ, the original mediator, had disappeared. The Church constitutes the model for, and the precursor of, the modern state, and allows one to grasp the state's intermediate position between the 'two worlds' of pure normativity and sheer facticity, which is a position that aims to assert, in actuality, the authority of an extra-earthly normative ideal. The construction is, thus, strictly top-down, as Schmitt's suggestive analogy between papal infallibility and absolute monarchy shows. The particular virtues or vices of the individuals who transiently hold such offices are irrelevant, for the transcendent qualities attach solely to the office, not to the "empirical" person. The pope is infallible insofar as he stands vicariously for Christ on earth; the king is the state insofar as he is law made flesh (Schmitt, 1914: 95-96).

In the course of his reflections on the nature and value of the state, Schmitt takes issue with the Kantian tradition. Having graduated and gotten his Habilitation from the University of Strasbourg, Schmitt must have been more directly exposed to the so-called Southwest German school of neo-Kantianism, where the concept of normativity played a central role (Beiser, 2009). Interestingly, however, he targets especially the Marburg group of neo-Kantians, ${ }^{4}$ whose distinction between law and ethics he deems unconvincing. Indeed, in a bold argumentative move, he charges both Kant and his neo-Kantian followers of being unable to uphold a clear distinction between ought (Sollen) and is (Sein). ${ }^{5}$ In Schmitt's view, the Kantian conception of the legal imperative as an 'external' one, in contrast to the 'internal' source of the 
ethical imperative, makes the distinction collapse. If both ethics and the law belong to the normative realm of Sollen, then the specific difference between them cannot rest on the contrast between autonomy and heteronomy, for heteronomy implies coercion, and coercion belongs to the empirical realm of Sein (Schmitt, 1914: 56-66). The result of Schmitt's critique is that the state takes on the key intermediate position in between the 'two worlds' of norms and facts which, in the Kantian tradition, was reserved to the individual. For Kant and his followers, genuine authority, in matters of both morality and knowledge, could only be found inside the individual. The laws of the physical world, as well as the imperatives of practical reason, are rooted in the universal rational structure of the mind. In this sense, it is quite ironic that Schmitt uses Kant to make an anti-individualist point. In fact, against the notion that the worth of the individual might be rooted in "nature," Schmitt (1914: 98) quotes a passage from Kant's Groundwork for the Metaphysics of Morals, which states that law (das Gesetz) is the only source of value. He forgets, however, that the law Kant is referring to is not state law, but rather that of the universal legislator rooted in each individual mind. By relegating the individual to a lower sphere of facticity, Schmitt ends up displacing, against the spirit of Kantian philosophy, the concrete source of law, value and authority from the individual to the state:

Value in law and in the mediator of law, i.e. in the state, is therefore measured only according to the norms of law, not according to things that are endogenous to the individual.

(Schmitt, 1914: 102) ${ }^{6}$

Schmitt's first incursion into the themes of political theory climaxes, thus, in the claim that, for all relevant legal and political purposes, there is no intrinsic value in the individual. Only the exogenous authority of the state, whose dignity derives from the supernatural normative ideal it mediates, can elevate the 'empirical' individual to the status of a legal/political subject. Despite the initial neo-Kantian framework and its normative idealism, it seems to me that already in Der Wert des Staates, Schmitt understood quite well that his valorization of the state prompted him to go beyond and even against Kant. ${ }^{7}$ He will do so, without ambiguities, from his earliest interwar writings on. Before proceeding to them, however, let us consider Schmitt's experience at the home front during the First World War and its impact upon his intellectual trajectory.

\section{Idealism Shattered: Schmitt's Wartime Experience}

Carl Schmitt led a double intellectual life in Munich during the First World War. Declared unfit to fight at the front due to a back injury, he was assigned to work as a lawyer in the General Command of the 
Bavarian Army, where he was responsible for the censorship of literary and journalistic publications. Besides this routine work as a cog in the military machinery, he was also active in Munich's bourgeoning avantgarde scene, entertaining literary ambitions of his own. This division of labour, which was not without its tensions and occasional conflicts of interest, is reflected in his wartime intellectual output, where a laudatory book on Theodor Däubler's expressionist poetry and a dystopian sci-fi satire (Schmitt, 2019) stand alongside the legal articles arising from his official duties in the General Command. If Schmitt was tempted by the bohemian lifestyle of his artist friends, which compared favourably to the bureaucratic work he performed for the military, eventually he ended up following his daytime vocation as a jurist. It is in the context of this rather conventional professional choice that his radical attack on juristic convention will gain firmer ground, dissipating the hesitations of earlier writings. His wartime legal articles, even if they started as reluctantly taken bureaucratic exercises, contain the first expression of a new conception of authoritarian rule, which reverses the previously posited priority of the realm of norms over that of facts.

The transformation of Carl Schmitt's thought during the First World War shows that not only experiences at the battlefront, or reflections on those experiences in the immediate aftermath of the event, produced major instances of intellectual change. However, contrary to what Rogers (2016: 123) argues in a nevertheless stimulating article, this transformation should not be seen as one where prior 'liberal commitments' and 'a visceral anti-authoritarianism' gave way to a new 'maximally authoritarian' position. The notion that Schmitt had not consolidated a relatively clear ideological allegiance in his early works is a misconception. ${ }^{8}$ The ideological shift he went through was one within conservative authoritarian thought, namely, from a traditionalist devotion to the monarchical state, albeit tinged with neo-Kantian idealism, to a radical neo-authoritarian conception of the state. In the lines that follow, I intend to clarify how the war contributed to this shift by juxtaposing Schmitt's cultural critique of modernity and the case he makes in his legal writings for unbounded military dictatorship.

Rogers (2016) rests his argument on the striking dissonance between, on the one hand, the contents of Schmitt's personal journals, where throughout 1915 he voices strong antipathy towards militarism, and, on the other hand, the justification of a maximalist interpretation of wartime military dictatorship put forward in the legal articles he was commissioned to write. Undoubtedly, Rogers uncovers a personal drama to which Schmittian scholarship —including Mehring's massive biography—paid hitherto little attention. However, it is doubtful whether the anxieties with the militaristic crushing of (his) individual self-determination and private life Schmitt confided to the diaries, or in letters to his future wife, can be interpreted as an ideological commitment to liberal values. 
To make a strong case for such a supposed commitment, one would have to find traces of it in Schmitt's public writings. However, these are nowhere to be found. Contrary to what Rogers (2016: 133) argues, in Der Wert des Staates, Schmitt does not use the 'value of the individual, in characteristically liberal fashion, to retroactively affirm the state.' As our analysis of that work has shown, there is no retroactive move whatsoever in Schmitt's reasoning. Value flows downwards from the supraempirical realm of law, mediated by the state, to the individual, who, for the purposes of legal and political science, possesses no intrinsic worth. ${ }^{9}$ In addition, there is also nothing in Schmitt's short review of Walther Rathenau's ${ }^{10}$ Zur Kritik der Zeit even remotely close to 'a defence of individualism associated with other liberal values' (Rogers, 2016: 133). In fact, Schmitt (1912b) agrees with Rathenau's verdict that the modern age has become mechanistic and soulless, but considers his approach unable to go to the root of the matter, thus rendering the industrialist's portrait of the age a lament rather than a critique.

Schmitt's own Kulturkritik, which the author exercised in his literary works, would arguably have been the place to look for the traces of liberal commitments, should there be any, for here he wrote without having to take into account bureaucratic duties or strategic considerations of career advancement. What one encounters, though, is a virulent critique of the modern age, seemingly imbued in Christian spiritualism, which places Schmitt unambiguously on the right side of the modernist political spectrum. ${ }^{11}$ His praise of Theodor Däubler's epic poem Das Nordlicht (1910) is a case in point. The encounter with Däubler's poetry, but also with the writer's magnetic personality, left deep marks in the young Carl Schmitt. They met in Berlin, in 1912, and travelled together with friends across the Rhineland during that same year, visiting exhibitions and discussing literature, painting and music. In the frontispiece of Der Wert des Staates stands a quote from Däubler's Nordlicht that is hardly a liberal motto: 'First is the command, people come later.'12 In 1916, Schmitt published a monograph on Das Nordlicht, which interprets Däubler as the poet who represents the antipode of ' $[\mathrm{t}] \mathrm{his}$ age which calls itself capitalist, mechanistic, relativistic, the age of exchange, technology and organisation. ${ }^{13}$ The final part of the study, which assesses the epochal relevance of the epos, contains Schmitt's verdict on the modern age and its men:

They want heaven on earth, heaven as the result of trade and industry, which should effectively exist here on earth, in Berlin, Paris or New York. A heaven with bathing facilities, automobiles and club chairs, whose holy book would be the timetable. They do not want a God of love and mercy. Having "made" so many astounding things, why should they not "make" a heavenly tower on earth. The ultimate and most important things have already been secularized. Law turned into power, fidelity into predictability, truth into generally 
recognized correctness, beauty into good taste, Christianity into a pacifist organization. A pervasive reversal and falsification of values dominated the souls. A sublimely differentiated usefulness and harmfulness took the place of the distinction between good and evil.

(Schmitt, 1916: 60-61) ${ }^{14}$

There is nothing liberal in this strong indictment of bourgeois society, depicted as a complete inversion of the rightful transcendent order. Indeed, Schmitt (1916: 62) sees in it the work of the Antichrist himself, whose "mysterious power' leads men to the presumption that they can "'make" Providence as if it were any given institution. ${ }^{, 15}$ Still, in contrast to the cultural criticism of many conservatives, Schmitt's horizon was not regressive, nor was his outlook dominated - not yet, at any rate - by anthropological pessimism. Furthermore, he seemed disinclined to "nationalize" his condemnation of modern Man, a common feature among war enthusiastic intellectuals at the time, in terms of a struggle between "organic" German culture and "mechanistic" Western civilization-Berlin, alongside Paris and New York, appeared as a site of modernity's 'pervasive reversal and falsification of values.' In the Nordlicht study, Schmitt (1916: 53) still voiced the conviction that nature and men-despite the temptation of evil-were fundamentally good. There was sound cause for not giving up all hope, since Däubler's poetry, as Schmitt (1916: 70) concluded, announced in dialectical terms that 'the last negation leads to the overcoming of all relativity' and to the final 'triumph of spirit over doubt." This is perhaps the last expression of his youthful idealism, which had sustained the devotion to a benign authoritarian state deemed capable of "realizing" the supra-empirical dignity of law. The world at war around him was about to shatter it. ${ }^{17}$

Indeed, the war soon made Schmitt come to terms with a world where the abstract priority of law over power, of the supra-empirical realm of norms over the concrete demands of the actual political situation, was exposed as idle speculation. In this regard, Rogers (2016: 133-134, 143-145) digs out from Schmitt's journals and letters a most revealing 'inversion of the Kant-Napoleon hierarchy,' even if he reads it erroneously as a turn away from previously cherished liberal values. What this reversion entails, in my view, is that Schmitt came to adopt the Napoleonic criterion of reality, i.e. the specific rationality of the statesman and military commander who calculate the necessary means to achieve some desired end, as a new point of departure for legal and political theorization, ditching aside the predominantly contemplative mode of thought of German idealism. From now on, he would affirm state authority from the perspective of the extreme case, which requires extraordinary measures to salvage order in face of an actual, existential threat.

Schmitt's wartime legal articles constitute the first steps towards such a new, radical theory of authoritarian rule. They emerged as part of the 
debates among German jurists concerning the nature, purpose and limits of the so-called state of siege (Belagerungszustand) that the Kaiser, making use of the Kommandogewalt that the 1871 constitution granted him, declared at the outbreak of war in order to catalyse the extensive mobilization of human and material resources that modern, large-scale warfare required. This state of emergency transferred numerous special powers to the military authorities, and Schmitt (1916/1917; 1917), writing at the request of the military, argued for an extensive interpretation of such powers. His basic, utterly un-Kantian ${ }^{18}$ strategy in both articles is to push the tension between theory and practice, validity and efficacy, to a limit where all "merely" normative claims formulated by civilian bodies against the military administration become meaningless, because the latter is considered to be operating in a realm which, through the law of emergency, has been drained of all law, and where only factual considerations apply:

The legal treatment of the purely factual state of a concrete danger, thus, is carried out in such a way that a lawless space is carved out from the law, within which the military commander may use any means that he deems suitable.

$\left(\right.$ Schmitt, 1916/1917: 159) ${ }^{19}$

It is evident that here the law has fallen from the pedestal of supreme dignity and primacy to which Der Wert des Staates had elevated it. The war proved that, in a situation of existential threat to state order, normative claims must inevitably surrender to the means-ends calculations of military action. In fact, more than that, it disclosed to Schmitt something about the very nature of the state which forced him to reverse the priority of abstract, supra-empirical law over concrete, empirical facts. He now views the sphere of facts as both logically and chronologically prior to that of norms, as the 'originary condition' (Urzustand) of the state (Schmitt, 1916/1917: 157). The state of siege, thus, signified a temporary return to the executive-administrative origins of the state, but in terms of its historical significance, it might mean more than a merely provisional suspension of abstract legislative legality. Indeed, if the neo-Kantian phantasy with self-contained normativity was abandoned, Hegelian dialectics now served Schmitt the purpose of suggesting the supersession of the separation of powers. Dictatorship, as he avers by the end of 'Diktatur und Belagerungszustand,' could be understood as the 'negation of the negation,' i.e. as superseding the separation of powers and generating a new, superior form of highly concentrated state unity (Schmitt, 1916/1917: 160). However, that this new form might entail a complete overturn of traditional authority by military-administrative means, and not the rule of a military hierarchy faithful to tradition, will only be clearly articulated by the author in the political context of the Weimar Republic. ${ }^{20}$ 


\section{Sovereignty Beyond Tradition: From Dynastic Legitimacy to Neo-Authoritarian Dictatorship}

\section{Towards an "Exceptional" Account of the Modern State}

The first book that Schmitt published after the war was a biting critique of Political Romanticism. In various respects, this is a transitional work. On the one hand, even if published in 1919, it was written in 1917/1918 (Schmitt, 1986: 21), and in that sense it would be more accurately categorized as a wartime output. Moreover, from a formal point of view, it is a blend of literary, historical and political-philosophical analyses, merging the diverse intellectual interests that marked the author's trajectory until 1918. But, on the other hand, it already contains the first formulations of two crucial, interconnected features of Schmitt's Weimar-era writings, namely, his theory of secularization and the critique of bourgeois liberalism.

Schmitt holds that the key to understand Political Romanticism lies in the dislodgment of the medieval, theistic conception of a personal God, which undergirded the monarchical principle of political representation. By the end of the eighteenth century, two 'demiurges' had emerged to take the place of the transcendent God of traditional Christian metaphysics: the 'revolutionary god' of humanity, the people or society-Schmitt does not yet distinguish judiciously between these concepts, as he later would - and the 'conservative god' of historical tradition (Schmitt, 1986: 58-64). The political romantic, however, evades a final decision on which of these new gods to embrace and instead fluctuates irresponsibly between the revolutionary and the reactionary poles. His attitude is, according to Schmitt, a reinterpretation of the deistic metaphysics of Cartesian philosophy, which, as the author would put it in Political Theology, discarded God's active intervention in the world just as the constitutional monarchy rejected the sovereign's personal intervention in the legal order (Schmitt, 2009: 43). This is a reinterpretation that privatizes the impersonal, withdrawn God of deistic metaphysics and takes the emancipated, isolated individual of bourgeois society, floating above revolution and restoration, as its point of reference and measure of the absolute. The liberal bourgeoisie is thus, according to Schmitt, the specific social carrier of the romantic political attitude, as exemplified by the vacillations of literati such as Adam Müller and Friedrich Schlegel, which he exposes and derides at great length. This attitude is reduced 'to its simple principle of a subjectified occasionalism' (Schmitt, 1986: 161), which is constitutively incapable of making moral and political decisions, formulating scientific concepts or thinking in any systematic fashion, and instead takes every objective content as an occasion for subjective aesthetic experience. ${ }^{21}$

Nonetheless, even if the importance of making fundamental decisions, of facing the either-or of ultimate choices instead of dissolving each and every antithesis, emerges very clearly in Political Romanticism, Schmitt 
does not yet come across as a decisionist, but rather as a traditionalist. One of his main concerns is to oppose the amalgamation of politicalromantic ideas with the counterrevolutionary doctrines of Burke, Bonald and Maistre, exposing the points of contact between them as incidental and vacuous. 'Legitimacy,' the fundamental principle of political order for the reactionary philosophers, 'is an absolutely unromantic idea' (Schmitt, 1986: 124). All counterrevolutionary thinkers were active politicians engaged in real struggles, not passive political literati seeking experiences of subjective aesthetic satisfaction. They fought for what they considered to be right and just, and what they considered to be right and just was handed down to them by a historical tradition, by the accumulated wisdom of prior generations, and was ultimately grounded in God, viewed as 'the ultimate principle of political life in legitimist theories of political philosophy' (Schmitt, 1986: 116). Against both revolutionary natural law and romantic-bourgeois indecision, Schmitt sided with these legitimist theories, and so much so that, as Schoonmaker (1988: 130) keenly put it, 'Political Romanticism...could have been aptly subtitled "The Need for Traditional State Authority in a Mass Society." In that sense, from the perspective of Schmitt's theory of authoritarian rule too, this is a transitional work, which does not yet take up the possibility, intimated in the wartime legal articles, of discarding guiding normative principles altogether and making state authority rest entirely on the primal force of sheer facts.

It is, in my view, no accident that Schmitt was only able to articulate a new conception of authoritarian rule when history made him a citizen of a republic that acknowledged the principle of popular sovereignty. With the collapse of the European continental empires in the aftermath of the Great War - a consequence that few in Germany anticipated even as the military conflict drew to a close-the democratic idea triumphed as the only generally recognized principle of political legitimacy in the continent. This triumph, to be sure, constituted an enormous challenge for someone who had just endorsed and extolled the relevance of political doctrines which, based on the dynastic principle of legitimacy, stringently defended monarchic authority. The Revolution of 1789 had finally succeeded, by the end of a long century of political struggles, in establishing beyond dispute the democratic principle of validity. However, as Schmitt will seek to argue, this did not entail a wholesale surrender of the state, or of state theory, to liberal ideas. An authoritarian reinterpretation of modern democracy was possible, and Schmitt takes a decisive step towards it in his 1921 monograph on dictatorship.

Dictatorship is, on par with his later Constitutional Theory (1928), Schmitt's most scholarly work. In contrast to the polemical tone of Political Romanticism, here the style is erudite, at times even aridly academic, and it seems that the author intends to present a balanced examination of the object of study, rather than defend a position or articulate a specific 
thesis on the topic. He introduces the book as the first systematic enquiry into 'a central concept of state and constitutional law,' which, perhaps because of its ordinary use as a political catchword, had thus far received only marginal attention by scholars of law and politics (Schmitt, 1921: iii). To be sure, this is not an entirely misleading rendering of what the study aims at, and Schmitt's earlier research for the wartime legal writings had equipped him with the means to achieve such a systematization. However, there is more to Dictatorship than serious, impartial scholarship. My contention is that, in between the lines, it lays the groundwork for a rearticulation of personal authoritarian rule in the age of democratic mass politics. The key to grasp this second, subterranean line of reasoning is to interpret the book more broadly as an account of the rise of the modern state that emphasizes the exceptional and personal dimensions of its form of domination over against the supposedly continuous, linear trends of increasing routinization, rationalization and impersonal bureaucratization.

That Schmitt understood the state, to paraphrase Dyson's (1980) useful distinction, both as an idea and as an institution, both as a politicalphilosophical concept and as an actually existing power apparatus, is plain to see from the structure of the monograph. The author alternates between the discussion of state theories and their conceptions of dictatorship, from Machiavelli to Marx, and the analysis of state praxis in its dictatorial aspects, from Innocent III's (1198-1216) assertion of papal plenitudo potestatis to article 48 of the Weimar constitution. ${ }^{22}$ This back and forth between theory and practice is organized around, and illuminated by, a sharp conceptual definition immediately followed by a fundamental distinction. Schmitt (1921: vi) defines dictatorship as a state of exception (Ausnahmezustand). The exception suspends the normal state of affairs in a polity, i.e. the norm as defined by positive law or by an ultimate political ideal, in order to produce a specific effect, to achieve a concrete goal in the sphere of facts, thus intervening directly in empirical political reality. Frequently - and here resides the tension lying at the very heart of the concept - the goal is to assure (the factual conditions for) the survival and maintenance of the norm, which might be jeopardized either by an external military threat or by domestic instability. The appropriateness of the concrete measures taken to achieve the goal is determined on a purely instrumental basis. In the normative void created by the state of exception, only factual considerations apply, and these vary according to circumstances, which might require the suspension of inherently different elements of the normal situation. For example, it might be necessary to suspend both liberal provisions safeguarding individual rights and democratic principles of government, but this should not lead one to equate both. In this context, the author is particularly keen on emphasizing, in opposition to what he sees as an emerging trend in ordinary parlance, that dictatorship and democracy must not be conceptualized as antonyms. 
Rather, the crucial question for further elucidation of the concept is that of sovereignty: Who has the authority to suspend the norm and authorize a dictatorship? The key distinction between commissarial and sovereign dictatorships, which Schmitt presents as the main result of his enquiry, proceeds from the notion that there are two qualitatively different instances of supreme authority. On the one hand, the instance that authorizes a dictator may be already constituted, in which case dictatorship is understood strictly as a commission, as an assignment located within the bounds of the existing constitution. This is the traditional understanding of the concept, which has its half-mythical, half-historical origins in early republican Rome, where magistrates had occasionallyand strictly provisionally — been given extraordinary, unlimited powers to supress a major threat to the extant order, selflessly relinquishing them as soon as the emergency that had justified their appointment was overcome (Schmitt, 1921: 1-2). Conversely, the supreme authorizing instance can be conceived as a constituent one, in which case dictatorship acquires a transformative and revolutionary dimension, paving the way towards a new order, towards a constitution to come. This sovereign understanding of dictatorship, as Schmitt briefly points out (1921: 3), also had its antecedents in the ancient Roman tradition, namely, in the convoluted transition from republic to empire through the dictatorships of Sulla and Caesar, often thematized in close connection with the old problem of tyranny. However, Schmitt glosses over this tradition and instead treats sovereign dictatorship essentially as a product of modern revolution. ${ }^{23}$ As he put it towards the end of Dictatorship's preliminary remarks:

In the eighteenth century, a novel understanding of dictatorship appears for the first time in the history of the Christian West. According to this understanding, the dictator still remains a commissar. However, because of the peculiar, not constituted but constituent, nature of the people's power, he emerges as a direct commissar of the people, as a dictator who also dictates to his superior, without ceasing to legitimize himself through that superior.

(Schmitt, 1921: $\mathrm{x})^{24}$

The temporal horizon within which Schmitt, despite his extensive knowledge of classical antiquity, chooses to frame the emergence of sovereign dictatorship is, thus, that of his theory of secularization. As long as sovereignty had remained grounded in the firm foundations of Christian metaphysics, dictatorship was only conceivable in its commissarial understanding, as a delegation from the one who ruled by the grace of God. For Schmitt (1921: 25-37), Bodin was the chief theorist of this understanding. European divine-right monarchies rested on such metaphysical foundations, even if their gradual transformation into-and legitimation as - modern states was shaped by the contributions of metaphysically 
indifferent, practically oriented theories, such as those of Machiavelli, and by rationalistic varieties of natural law thinking, such as Hobbes's (Schmitt, 1921: 7-24). On the other hand, those lineages of natural law theory that argued for the right of resistance and rebellion against a despotic monarch (e.g. Locke), which Schmitt (1921: 24-25) interprets as part of the feudal opposition to royal state-building projects, had their radical, revolutionary potential curtailed by the fact that they could only picture the deposition of a tyrant by the people as the restoration of a status quo ante, which was deemed to correspond to a divinely ordained order of society.

The condition for the emergence of a sovereign understanding of dictatorship, according to this perspective, was the breakdown of the belief in a transcendent God as the ultimate source of all earthly authority. Only when the final authority-granting instance became a world-immanent one, i.e. the people, could both the theory and the practice of dictatorship become transformative and revolutionary. In Schmitt's (1921: 140-146, 153-167) narrative, thus, Sieyès's theory of the people's pouvoir constituant takes the place of Bodin's conception of sovereignty, while in state practice, the people's were substituted for the royal commissars, mediated by a transitional phase where the metaphysical and anthropological tenets of monarchical absolutism were eroded by Enlightenment philosophy (Schmitt, 1921: 112-129). ${ }^{25}$

The implications Schmitt draws from this travelling of the final source of authority from a transcendent plane to an immanent basis put him at odds with the Weberian account of modernity as an age where, inter alia, impersonal, legal-rational forms of authority take an inescapable hold on the fate of Western humanity. Weber is not mentioned once in Dictatorship, but the book can fruitfully be read as an account of the formation of the modern state, and of the development of its theory, which seeks to refute Weber's sociology of domination and its emphasis on the inescapable technical rationalization, de-personalization and bureaucratization of forms of rule. For, by underscoring the misty, ebullient, abysmal nature of the people's pouvoir constituant, in contrast to the previous conception of a transcendent God as a fixed point where all earthly derivation of legitimate power culminated, Schmitt moves to the antipodes of Weber's diagnosis concerning the impossibility of revolution - 'in the sense of the forceful creation of entirely new formations of authority' (Weber, 1978: 989) — in the modern age:

The theory of the pouvoir constituant is incomprehensible simply as a form of mechanistic rationalism. The people, the nation, as the primordial force [Urkraft] of the state, always constitutes new organs. From the infinite, incomprehensible abyss [Abgrund] of its power, new forms emerge incessantly, which it can destroy at any time and in which its power is never limited for good.

(Schmitt, 1921: 142) $)^{26}$ 
Indeed, with the advent of the new, immanent source of final authority, 'new revolutions and a new appeal to the pouvoir constituant are always possible' (Schmitt, 1921: 145). ${ }^{27}$ Now, for a revolutionary dictatorship to emerge, the occurrence of an emergency, of a concrete threat to the extant order, becomes superfluous. The existing order itself can be 'seen as an inhibition to the free exercise of the pouvoir constituant' (ibid.), and therefore constitute the very obstacle to be supplanted through sovereign dictatorship. The new ultimate grounds of authority, as Schmitt (1921: 139, 145-146) underscores, had not merely stepped into the shoes of the transcendent God and inherited His attributes. Like God, the people in its constituent capacity comes before and stands above each and every constitution, but unlike Him, the people belongs to this world and is an ever-present, potentially active factor in it, whose power can be mobilized at any moment to obliterate the existing constitution. The intense language Schmitt uses to conceptualize the constituent power of the people, here as well as in Constitutional Theory, is perhaps the single most important reason why many left-radical democratic theorists have been fascinated by his work. ${ }^{28}$ However, though Schmitt was arguably captivated by what he perceived as the irrationalism of Sieyès's theory, a more careful analysis of his language suggests that its intensity, which to some ears might sound as an apotheosis of popular sovereignty, might actually be the product of horror and shock in the face of the dissolution of the traditional, long-lasting forms of political representation in Christian Europe. The description, in the above-quoted passage, of the pouvoir constituant as an 'incomprehensible abyss' (unfaßbaren Abgrund) is dismal rather than celebratory. Furthermore, when the author points out that, for the old natural law tradition of theories of resistance to royal abuse, the people was equated with its aristocratic representation by the feudal lords of the estates society, he adds that it was 'evidently' not the 'plebs,' not the 'incondita et confusa turba' (the disordered and confused crowd), and that a 'new radicalism' only came about when 'the people in its unmediated and unorganised mass, rejecting representation' appeared on the world-historical stage (Schmitt, 1921: 25). He was not that far away here, though many have failed to notice this, from the bourgeois language of class anxiety that permeated late nineteenth-century crowd psychology. ${ }^{29}$

At the end of the day, one must not forget that Schmitt was discussing dictatorship, not revolution or popular sovereignty per se. By going against the grain of a Weberian reading of modern political domination, Schmitt was in fact fostering the idea that the age of mass politics, far from narrowing it down, opens up a broader spectrum of possibilities for the assertion of dictatorship as a personal and exceptional form of rule. If he would have engaged Weber directly in Dictatorship, Schmitt could have traced the emphasis on the routinization and de-personalization of modern politics to Weber's neglect of the problem of sovereignty. Weber, 
indeed, rarely employs the concept of sovereignty, be it in his sociology of religion, of law or of domination. ${ }^{30}$ The reference to the "monopoly of legitimate physical violence within a certain territory,' often quoted as a definition of modern state sovereignty, is presented by Weber (1994: 310-311) in Politik als Beruf simply as a definition of the state, and the term "sovereignty" is entirely absent from the published version of the lecture. ${ }^{31}$ That Weber was sceptical of its value for sociological analysis can be gleaned from a passage in his sociology of law, where it appears within quotation marks, even if he concedes that there are 'good juristic reasons' for treating sovereignty 'as the essential attribute of the modern state' (Weber, 1978: 670). ${ }^{32}$ In contrast to such scepticism, Schmitt was maximally interested in the question of sovereignty. According to him, precisely this question unveiled the central importance of the moment of personal rule throughout the history of the modern state, from its early modern beginnings to his present day, even if it 'often takes a back seat because of the accent on the centralized apparatus' (Schmitt, 1921: iv). As he puts it towards the end of Dictatorship, constitutional liberalism in continental Europe, in its heyday, might have entertained the illusion that, with the destruction of the feudal intermediary powers of the Old Regime, 'the homogeneity of the state would not be seriously threatened by social factions within it' any longer, and thus that dictatorship could be subjected to thorough legal regulation, just like any standard civil or criminal procedure (Schmitt, 1921: 203). ${ }^{33}$ Soon, however, the rise of the revolutionary proletariat would shatter such an illusion. Thus, in the aftermath of the First World War, dictatorship was as topical as ever.

\section{The Decision for Sovereign Dictatorship}

One year after the dense study on Dictatorship, Schmitt published a tightly argued booklet under the title Political Theology, which-next to the 1932 version of The Concept of the Political - is possibly his most widely read and translated work. However, if one carefully juxtaposes it to the previous monograph, one arrives at the conclusion that there is hardly anything substantively new in these four short chapters on the concept of sovereignty. The difference is, in essence, one of style. Ideas, which in the earlier work were buried amidst the perusal of historical and philosophical materials, or formulated in cautious terms, now surface with a trenchant edge. Political Theology is the polemical supplement to Dictatorship — and for our purposes, it has the benefit of displaying Schmitt's neo-authoritarian vision in sharper contours.

The polemical intent makes Schmitt name or allude unambiguously to his intellectual opponents. While in Dictatorship the shadows of Max Weber and Hans Kelsen hovered over the entire work without being confronted, now the two are identified in several important instances. ${ }^{34}$ Yet, while the confrontation with Kelsen is quite explicit and has been stressed 
by many commentators as a crucial key for interpreting Political Theology (Baume, 2009; Vatter, 2016: 247-250), the polemical demarcation from Weber is concealed beneath neutral or seemingly complimentary references. However, it is no less decisive. Ulmen (1991: 169-224), although drawing especially on Roman Catholicism and Political Form from $1923,{ }^{35}$ interprets Schmitt's project as a Catholic counterweight to Weber's Protestant Ethic, which shifts the focus from the sphere of economics to that of politics and simultaneously puts forward a wholly different understanding of secularization. Colliot-Thélène (1995) treats Schmitt's polemical engagement with Weber as the reply of a political to an economic thinker, a view which, albeit skilfully crafted, oversimplifies Weber's approach. ${ }^{36}$ In the remainder of this section, we will argue that the core of Schmitt's opposition to both Weberian sociology and Kelsen's jurisprudence lies in his insistence upon the ineradicably personal nature of political authority. However, confronted with the obsolescence of the belief in the transcendent origins of earthly rule, such an insistence must go beyond a traditionalist justification of state authority.

The external circumstance that the first three chapters of Political Theology were republished in 1923, with a few minor additions, in a massive edited volume in Weber's memory - under the title 'Soziologie des Souveränitätsbegriffes und politische Theologie' (Schmitt, 1923) - constitutes in itself a clear proof that Schmitt conceived the work at least partly as an engagement with Weber's legacy. ${ }^{37}$ But let us move to the text itself. 'Sovereign is he who decides on the state of exception, ${ }^{38}$ tells us Schmitt (2009: 13) in the famous opening sentence. The state of exception, he proceeds, must be understood here as a 'borderline concept' (Grenzbegriff) that pertains to a veritable 'borderline case' (Grenzfall), not to the sort of emergency that could be dealt with by a commissarial dictatorship within the constitutionally and legally regulated bounds of a state of siege. Situated at the very threshold of the legal order, the "borderline case' imposes a decision in the fundamental legal and political sense of the word, which reveals the subject of sovereignty as the one

who decides whether there is an extreme emergency as well as what shall be done to eliminate it. He stands outside the normally valid legal order, but nevertheless belongs to it, for it is he who decides whether the constitution can be suspended in its entirety.

(Schmitt, 2009: 14) ${ }^{39}$

McCormick (1998: 218-230) sees in the merger of these two decisions in one and the same subject a radicalization of Schmitt's stance compared to Dictatorship. In my view, however, that is not really the case. What has changed, if I may use McCormick's (1998: 217) own words, is Schmitt's 'mode of presentation' rather than his position. Indeed, already in Dictatorship, when discussing early modern jurists' views on the 
iura extraordinaria in the Holy Roman Empire, Schmitt (1921: 18) offers a definition of sovereignty that lumps together in one instance the two separate moments - the when and the what - of decision on the exception. ${ }^{40}$ Furthermore, as our analysis of that work has shown, there are good reasons to doubt that Schmitt analysed such a merger there as 'politically pathological' (McCormick, 1998: 223), even if, given the scholarly tone adopted by author, he did not openly endorse it either. McCormick's thesis of a radicalization of Schmitt's position in Political Theology results from overstating the extent of his moderation in Dictatorship, a work that the commentator interprets as an argument against the corruption of the commissarial understanding of dictatorship in the modern age. From such a perspective, and in contrast to our certainly less charitable reading of it, he treats Schmitt's glossing over the Roman tradition of sovereign dictatorship under Sulla and Caesar as evidence for the endorsement of the other, strictly commissarial, classical notion. Regrettably, to strengthen his point, McCormick is not always accurate in his citations from the original work. For instance, he quotes Schmitt (1921: v) as having established that 'the commissarial character of dictatorship' is 'the essential determination of the concept,' which 'is marginalized' when 'a distinction is no longer maintained between dictatorship and Caesarism' (McCormick, 1998: 220). However, what Schmitt actually says in that passage is not that the essential, but rather an essential aspect of the concept is overlooked by confounding dictatorship and sovereign Caesarism. ${ }^{41}$ That the sovereign understanding of dictatorship is equally plausible and relevant, and that the secularization of the ultimate source of authority engenders a process of conceptual change that renders it arguably the predominant determination of the concept - these are, in my view, the conclusions that Schmitt reaches already in $1921 .{ }^{42}$

Nevertheless, McCormick suggests an interesting explanation for Schmitt's supposed radicalization between 1921 and 1922, and one which the context of our study puts us in a privileged position to assess and elaborate upon. The commentator suggests that the alleged shift in Schmitt's orientation might be explained by his reception of Max Weber's concept of charisma (McCormick, 1998: 225). However, there is no evidence that, by 1922, Schmitt had a profound knowledge of Weber's theory of charisma, in particular, and of his sociology of domination, in general. After all, Weber's Economy and Society was posthumously published in the same year, and therefore it is highly unlikely - not to say impossiblethat he had read it before sending his own work to the press. In any case, the only direct quotations from Weber in Political Theology stem from Weber's sociology of law, which is indeed included in Economy and Society, though the reference is imprecise (Schmitt, 2009: 34, 49). ${ }^{43}$ Apart from that, throughout the text one finds allusions to other texts by Weber, and especially to Politik als Beruf. In that lecture, the concept of charisma is indeed briefly presented, as noted in the previous chapter, as one of the 
three ideal types of legitimate domination. However, that specific part of the lecture seems not to have left a deep impression on Schmitt, which is certainly strange since it would constitute a prime instance of secularization of an originally theological concept. ${ }^{44}$ Still, the parallel suggested by McCormick between Schmitt's alleged radicalization and Weber's use of the concept of charisma in his later political tracts, as opposed to the earlier sociological writings - a contrast which, incidentally, the commentator depicts in overly simplistic terms - is thought-provoking even if it remains unproven. Indeed, a comparison between Schmitt's theory of sovereignty and Weber's concept of charisma shows that the former went far beyond the latter in what concerns the endorsement of unbounded personal authority as a solution for modern political predicaments. Schmitt's (2009: 14) focus on the subject of sovereignty, which according to him exhausts the whole problem of sovereignty, his move away from what he deems as fruitless speculations over "What is sovereignty?"- -typically answered with some list of prerogatives - to the fundamental question of "Who is sovereign?" attests to his radically personalist vision of political rule. While, for Weber, the personal authority of charismatic personalities was the source of disruption of established patterns of domination, and thus through the concept of charisma he sought to grasp the enigma of political (and religious) innovation, Schmitt sees both the processes of radical political change and the very foundations of order as products of a sovereign personal will. For Weber, the personal authority of charismatic leaders was a revolutionary force, but the normal situation, in contradistinction, was the product of what he termed the "forces of everyday routine' (Weber, 1978: 252), i.e. to put it in admittedly rough terms, of immemorial tradition in the pre-modern past and rational legality in the modern age. For Schmitt, rather differently, the personal will of the sovereign stands both at the origin and at the end of the legal and political order; he creates the normal situation in the first place and is its last guarantor throughout. Hence, he opposes his conception of sovereignty explicitly to Weber's definition of the modern state, which emphasized the rationalized coercive apparatus at the expense of the, according to Schmitt, ineradicable personal element of authority:

A normal situation must be created, and sovereign is he who definitely decides whether this normal situation actually exists... The sovereign creates and guarantees the situation as a whole, in its totality. He has the monopoly of this last decision. Therein resides the essence of state sovereignty, which one must thus define, in juristically correct terms, not as a monopoly of coercion or domination, but as a monopoly of decision... The exceptional case reveals the essence of state authority most clearly.

(Schmitt, 2009: 19) ${ }^{45}$ 
After this demarcation from Weber's definition of the state, the first chapter of Political Theology ends in a crescendo. A whole lineage of 'rationalist' thought, stretching from Locke through Kant to Kelsen, is declared incapable of grasping the significance of the state of exception and distinguishing it from a situation of 'juristic chaos' (Schmitt, 2009: 20). In stark contrast, an irrationalist 'philosophy of concrete life,' which an exceedingly long footnote in Dictatorship had analysed in a cool, detached manner (Schmitt, 1921: 146-148, n.), is now celebrated for its capacity to meet 'the exception and the extreme case,' with no shortage of rather hyperbolic formulations (Schmitt, 2009: 21). ${ }^{46}$ The chapter concludes with a citation from an unnamed nineteenth-century Protestant theologian, who apparently had vindicated with 'vital intensity' the primacy of the exception over the universal. In fact, it is an excerpt from Kierkegaard's Repetition, which, as Löwith (1984: 37-38) keenly remarks, Schmitt truncates and misquotes in one decisive instance, by rendering what the Danish philosopher had termed 'a legitimate exception' (eine berechtigte Ausnahme) as 'a real exception' (einer wirklichen Ausnahme) ${ }^{47}$ Although Schmitt omits it, in that very same passage Kierkegaard (2009: 78) also speaks of exceptions that are 'not legitimate,' to which the universal thus should not yield, and more generally the relationship between the exception and the universal is thought by Kierkegaard not as one of primacy of the former over the latter, but rather as an intrinsically tensional quest for the reconciliation of both, and more precisely, for a reconciliation of the exception in the universal.

In the second chapter of Political Theology, which in comparison to the first one comes across as a relatively arid discussion of the problem of legal form, Schmitt's main adversary is Hans Kelsen. Kelsen's legal theory, according to Schmitt (2009: 26), translates the Kantian distinction of Is and Ought into a strict methodological disjunction between sociology and jurisprudence, and therefore cannot grasp the 'fundamental problem of the concept of sovereignty,' which lies precisely in 'the combination of factual and legal highest power. ${ }^{48}$ The interpenetration of the normative and the empirical is, indeed, something that Kelsen's so-called pure theory of law, which we will treat more thoroughly in the next chapter, must dismiss as the product of a scientifically unacceptable methodological syncretism. Here, however, Schmitt (2009: 29) treats this refusal rather as 'the old liberal negation of the state vis-à-vis the law,' which testifies to an absolute 'disregard of the independent problem of the realization of law. ${ }^{49}$ For him, in contrast to the neo-Kantian legal theorist, a moment of decision underivable solely from the valid legal order itself, emanating instead from a concrete, personal decision-maker, is required for law and order to exist as properties of political reality.

When, however, Schmitt turns more specifically to the question of form, whose misperception he thinks has travelled from philosophy to 
sociology and jurisprudence, he tackles Weber again. Indeed, he distinguishes three concepts of form in Weber's sociology of law, which overcome each other and culminate in extreme rationalization and technicization. First, in a neo-Kantian vein, form appears as the transcendental condition of juristic cognition. Then, the specialization of the legal professions and the requirements of legal training further the need for regularity and calculability, until eventually the legal form becomes wholly governed by the technical ideal of frictionless functioning' (Schmitt, 2009: 34). The concept of form loses, thus, its specifically juristic - and political-determination. That at the bottom of such determination resides, in Schmitt's view, a foundational personal moment becomes clear when he again shifts the target to Kelsen. Schmitt holds Kelsen to incur in a contradiction when the Austrian scholar takes a subjectivist concept of form as the point of departure for legal sciencesubjectivist, that is, in the basic Kantian sense that knowledge is relative to the knowing subject - but at the same time, as regards his broader Weltanschauung, demands strict objectivity. ${ }^{50}$ And he concludes:

The objectivity that he [Kelsen] claimed for himself amounts to no more than avoiding everything personalistic and tracing the legal order back to the impersonal validity of an impersonal norm.

(Schmitt, 2009: 35) ${ }^{51}$

In sharp opposition to this erasure of the personal element-and of its connection to formal authority - from legal science, Schmitt puts forward what he coins as the decisionist type of juristic thought, which he traces back to Hobbes's political philosophy. This type of juristic thought, and this type only, can do justice to the peculiarity of legaland political - form by emphasizing, apart from the content, the significance of the subject of the decision. Contra Kelsen, Schmitt argues thus that the decisionist concept of form 'does not have the a priori emptiness of the transcendental form, for it arises precisely from the juristically concrete.' Contra Weber, in turn, he stresses that 'it is also not the form of technical precision, because the latter has a goal-oriented interest that is essentially factual and impersonal' (Schmitt, 2009: 40). ${ }^{52}$

In the third chapter of Political Theology, the twofold battle against Kelsenian jurisprudence and Weberian sociology continues, now waged from the vantage point of Schmitt's theory of secularization. 'All significant concepts of the modern theory of the state are secularized theological concepts,' argues Schmitt (2009: 43) in his characteristically epigrammatic style. The state of exception is no exception. It has the same meaning for legal and political theory as the miracle for theology: Just like God's omnipotence is affirmed by the ability to suspend the laws of nature, so is the sovereign revealed by the capacity and authority to suspend the extant constitutional order. Schmitt gives Kelsen credit for having called due attention to the methodological affinity between 
theology and jurisprudence. However, while the latter's aim was to emancipate jurisprudence from theological arguments which gave rise to a scientifically pernicious duplication of its object of study, Schmitt operates with a much broader concept of theology, which encompasses the metaphysical images of the world resting at the root of every legal and political idea. This allows him to ascribe to Kelsen's thought, which proclaimed to be militantly anti-metaphysical, a metaphysical character, namely, a 'metaphysics that identifies the lawfulness of nature and normative lawfulness,' deemed to be 'characteristic of the natural sciences' (Schmitt, 2009: 46) ${ }^{53}$ If, in the previous chapter, Schmitt had traced Kelsen's inability to grasp the problem of sovereignty to his strict methodological distinction between norms and facts, jurisprudence and sociology, now he imputes to his adversary's 'metaphysics' the reverse charge of conflating legal norms and natural-scientific laws. Alluding to Kelsen's 1920 article on the essence and value of democracy, Schmitt avers:

In the justification given by Kelsen for his commitment to democracy, the fundamentally mathematical and natural-scientific character of his thinking reveals itself: democracy is the expression of a political relativism and a scientific orientation that is liberated from miracles and dogmas, and based on human understanding and critical doubt. (Schmitt, 2009: 47) ${ }^{54}$

This "explanation" of Kelsen's thought reveals in what sense Schmitt's theory of secularization constitutes a "sociology" of legal and political concepts, an approach the author clarifies first by drawing on and then by drifting away from Weber. Referring to Weber's critique of Rudolf Stammler's historical materialism, Schmitt (2009: 48-49) asserts that the former had convincingly shown that the reduction of spiritual and intellectual phenomena to material conditions - and vice-versa - was untenable and bound to 'culminate in a caricature. ${ }^{55}$ Weber, to be sure, avoided such a reductio ad absurdum, but Schmitt (2009: 50), in turn, reduces Weber's highly ambitious research programme, which aimed to discern the complex and multidirectional causal nexuses between developments in the spiritual, cultural, political and economic spheres, to a psychology of social types which, even if pursued in a 'consequent manner,' cannot lead to more than 'social-psychological "portrait[s]" of essentially literary value. ${ }^{56} \mathrm{Schmitt}$ 's own "sociology," in contrast, lays claim to a higher scientific value when it comes to fundamental concepts, such as sovereignty. His aim is not to detect relations of causation, but rather to think concepts "through to the end" and thereby prove that legal and political concepts are, as it were, identical with the broader conceptual structure of a certain age:

The presupposition of this kind of sociology of juristic concepts is thus a radical conceptualization, i. e. an approach that is consistently pushed to the metaphysical and the theological. The metaphysical 
image that a certain age forges of the world has the same structure as what that same epoch immediately perceives to be the appropriate form of its political organization. The determination of such an identity is the sociology of the concept of sovereignty.

(Schmitt, 2009: 50-51) ${ }^{57}$

What Schmitt calls a 'sociology of juristic concepts' is thus, in essence, an anticipation of the research programme of post-WWII German conceptual history (Begriffsgeschichte), pioneered by Reinhart Koselleck's 1959 Heidelberg dissertation. ${ }^{58}$ The broad trend outlined in Schmitt's intellectual-historical narrative is basically the same that had served as a framework for the previous study on Dictatorship: There is an ineluctable move away from transcendent to immanent conceptions, both as regards legal-political ideas and all-encompassing metaphysical-theological worldviews. If the seventeenth and the eighteenth centuries, despite the emergence of a natural-scientific, rationalistic outlook, still held on to the ideas of God's transcendence vis-à-vis the world and the sovereign's transcendence vis-à-vis the legal order, the nineteenth century-especially after the revolutionary wave of 1848 - is marked by the definitive triumph of immanence. The monarchical conception of dynastic legitimacy loses metaphysical traction and is inevitably replaced by a democratic understanding of legitimacy, grounded in the immanent authority of the people. Kelsen's commitment to democracy 'as the expression of a relativistic and impersonal scientism corresponds indeed to the development that has asserted itself in nineteenth-century political theology and metaphysics' (Schmitt, 2009: 53). ${ }^{59}$ However, the Austrian scholar's conception is not the only one possible within the framework of a modern secularized metaphysical landscape.

In the final chapter of Political Theology, Schmitt articulates his owndecisionistic and sovereign-dictatorial-alternative conception. He does so by drawing on the Catholic counterrevolutionary philosophies of Bonald, Maistre and Donoso Cortés, whom he treats as forerunners of decisionism. However, Schmitt's interpretation says much more about his own, radical brand of neo-authoritarian statism than about the Catholic reactionaries themselves. The contrast to Political Romanticism is rather striking here, but the move away from traditionalism to decisionism in the interpretation of counterrevolutionary thought was also already, even if cautiously, suggested in Dictatorship.

A juxtaposition of the 1919 work with the final chapter of Political Theology, supplemented by an analysis of the transitional role of the 1921 monograph, is thus particularly instructive. Edmund Burke, profusely cited in Political Romanticism, disappears completely from the picture in $1922 .{ }^{60}$ Bonald (1754-1840), for Schmitt the founder of traditionalism, whom he had championed above all other reactionaries in 1919, is now treated in a single, somewhat ambivalent paragraph. To be sure, Schmitt 
(2009: 59) tries to defend him from the charges, levelled by some theologians, of 'extreme traditionalism' redounding in 'absolute moral passivity' and indecision. However, he now distances Bonald from Maistre and Cortés, whom he views as the true ancestors of decisionism. In contrast to the latter, we are now told, Bonald 'often showed himself to be really surprisingly German' (Schmitt, 2009: 60), i.e. to have some romantic penchants, even if he refrained from wholly succumbing to them. It is in fact extremely problematic to claim Bonald, for whom the order of political society flowed naturally from the divinely ordained order of domestic society, for the cause of decisionism. The French reactionary was a legitimist, but, as Schmitt (1921: 101) recognizes in Dictatorship, he was not a partisan of absolutist centralization. The legitimacy of dynastic succession was, for him, unquestionable, but so was the legitimacy of the intermediary bodies of feudal society. Both, indeed, were founded on the principles of heredity and the indissolubility of marriage stemming from 'the will of nature or rather of its Author' (Bonald, 1817: 170) ${ }^{61}$ instead of being derived from a decision taken in a normative void.

Maistre's (1753-1821) thought is also condensed in an equally short paragraph (Schmitt, 2009: 60-61), but the Savoyard reactionary is unmistakably elevated above Bonald. As Schmitt (2009: 69) formulates it towards the end of the chapter, Maistre already envisions 'a reduction of the state to the moment of the decision, to a pure decision without reasoning or discussion and not justifying itself, to an absolute decision created out of nothingness. ${ }^{62}$ This renders in a more flamboyant language a point the author had already made in Dictatorship, when he stated that Maistre drew 'the final consequences' of the Hobbesian intuition that ' $[t]$ he decision contained in the law is, from a normative perspective, borne out of nothing' (Schmitt, 1921: 23). ${ }^{63}$ For sure, Maistre was a partisan of strong monarchic rule, and the parallels he drew between royal sovereignty and papal infallibility constituted a novelty compared to premodern understandings of kingship, which indeed open up the possibility of a circumspect decisionist reading (Pranchère, 2001: 144). However, as an ultramontane thinker, he was concerned not merely with vindicating the authority of the state, but also that of the Catholic Church, whose indirect temporal power he wished to safeguard. As Fox (2017: 20) aptly reminds us, Maistre's book Schmitt quotes from is titled On the Pope, not On the King and much less On the Sovereign Dictator.

But the new champion of counterrevolutionary thought, in Political Theology, is the Spaniard Donoso Cortés (1809-1853), whom Schmitt (2009: 61) deems to have taken the decisive step from legitimacy to dictatorship. The conservative Spanish diplomat was not even mentioned in the first edition of Political Romanticism. ${ }^{64}$ In Dictatorship, his name emerges in footnotes only; yet, he is crucially identified as the source of Schmitt's (1921: 139, n. 1) analogy of dictatorship as a state of exception to a miracle. In Political Theology, the transition from dynastic legitimacy 
to dictatorship is explicated by Donoso's purported radicalization of the anthropological pessimism that, according to Schmitt, constituted a common feature of the Catholic reaction. 'Every political idea,' he says, 'takes a position on the "nature" of man and presupposes that he is either "by nature good" or "by nature evil"' (Schmitt, 2009: 61). ${ }^{65}$ While revolutionary socialists and anarchists believed in the natural goodness of man, and liberals and Enlightenment thinkers held on to the notion of man's perfectibility, Cortés took the dogma of original sin as his point of departure. However, the Spaniard allegedly went beyond the Catholic dogma in emphasizing the absolute depravity and baseness of the human species, and so much so that he was reproached by a cleric - according to Schmitt (2009: 62), quite rightly from a dogmatic theological perspective-for exaggerating the natural wickedness and unworthiness of humankind. ${ }^{66}$ Nevertheless, despite such an unfortunate entanglement in questions of dogmatic theology, Schmitt praised Cortés for his keen awareness of the fundamental religious and political decisions of his age. Seeing in liberalism merely an interim condition of paralysis and indecision, and in dynastic legitimism just a form of 'empty dogmatism,' Cortés had the courage, 'in the face of radical evil,' of calling for a dictatorship to prevent state authority from dissolving into anarchy (Schmitt, 2009: 69). ${ }^{67}$ Schmitt's stress on the misanthropic foundations of counterrevolutionary Catholic political theory, and especially of Donoso Cortés's thought, serves him the purpose of suggesting, by the end of the tract, that only political ideas that proceed from the assumption that man is "by nature evil" are truly political. Anthropological optimism, on the contrary, falls prey to the technicization and economization of the political, as the following passage, where Schmitt lumps together all his political antipathies, so expressively shows:

Today nothing is more modern than the struggle against the political. American financiers, industrial technicians, Marxist socialists, and anarcho-syndicalist revolutionaries unite around the demand that the unobjective rule of politics over the objectivity of economic life be done away with. There should only be organizational-technical and economic-sociological tasks, but no more political problems. The prevailing type of economic-technical thinking is no longer capable of perceiving a political idea. The modern state seems to have indeed become what Max Weber sees in it: a huge industrial plant.

(Schmitt, 2009: 68-69) ${ }^{68}$

At the end of the day, Schmitt (2009: 69-70) leaves us with a rather simplistic alternative between a self-contradictory dictatorship to end all dictatorships, based on the extreme anthropological optimism of the likes of Proudhon and Bakunin, and a dictatorship that salvages order and authority by recognizing the evil nature of man and drawing from such anthropological insight the necessary political consequences. ${ }^{69}$ 


\section{Filling the Void: The Homogenous Determination of the People}

The radical neo-authoritarian position as formulated in Political Theol$o g y$, with its emphasis on a sovereign decision 'created out of nothingness,' diverts one's attention from the specificity - and what follows from it - of a world-immanent source of political authority. Schmitt paid much closer attention to this aspect in the 1921 monograph, where sovereign dictatorship was inseparably linked to the people's pouvoir constituant as the foundation of French revolutionary rule. Indeed, the sovereign's order-creating decision might take place in a normative void, but it does not occur in a political vacuum. It is a consequence of Schmitt's theory of secularization, of the obsolescence of the transcendent conceptions which tied political rule to an origin beyond this world, that the ultimate grounds of authority acquire some degree of this-worldly consistence. Even if they remain latent and formless as constituent power, immanent legitimacygenerating grounds have certain political, sociological and cultural properties that the sovereign must tame and mould, so as to eventually represent, but which he certainly cannot create 'out of nothingness.' The sovereign must establish a unique connection and an indisputable claim to represent the immanent source of his authority. When the Weimar Republic entered a period of relative stability, from 1923 onwards, Schmitt's focus drifted increasingly to this peculiar aspect, i.e. to a more precise determination of the sources of modern political authority, which the initial formulation of his decisionism had left rather in the dark.

\section{The Dead End of Myth}

In 1923, Schmitt published another short treatise, again composed of four tersely argued parts and with an equally polemical edge to it, on The Crisis of Parliamentary Democracy. ${ }^{70}$ In the first half, the booklet lays out, in rhetorically powerful formulations, Schmitt's attempt to disentangle democracy from an allegedly decrepit liberalism and move it instead towards the orbit of dictatorship. ${ }^{71}$ In turn, the second half of the piece, to which present-day readers and commentators usually pay less attention, elaborates upon the sharp alternative - celebrating, eventually, the triumph of one over the other-between two diametrically opposed concepts of (sovereign) dictatorship, with which Political Theology had ended. This opposition, however, is preceded by the throwing away of a third theory of dictatorship, deemed historically and philosophically outdated.

Indeed, the penultimate part of the tract contains Schmitt's longest discussion of Marx's thought, to which there had only been fragmentary allusions in his previous works. Schmitt concedes that Marx's historical and dialectical materialism surpassed the abstract and moralistic nature of Enlightenment rationalism and its inclination towards 'educational 
dictatorship' (Erziehungsdiktatur). However, erected as it was upon Hegelian philosophical foundations, Marx's doctrine still understood the proletarian class struggle essentially as an intellectual category, thus conceiving the historical change it would bring forth in terms of a leap in consciousness, rather than as a concrete political task. This, he contended, had failed to motivate the Western European proletariat to take decisive action, depriving the working class, in the critical hour, of the courage to dictatorship. Marx, in sum, did not have the last word on dictatorship, and the proletariat would have to call upon an anti-intellectualist "philosophy of concrete life, ${ }^{72}$ if it were to rise to the occasion of its mortal battle with the bourgeoisie (Schmitt, 1988: 51-65).

The last section of Schmitt's essay on the Crisis of Parliamentary Democracy deals, thus, with what he labels as irrationalist theories of direct, violent political action. Here, the author relies mostly on Georges Sorel's Reflections on Violence (1908), whose ideas Schmitt claims to have been the first to introduce to a German audience. ${ }^{73}$ Influenced by Proudhon and Bakunin, but also by a vitalist reading of Bergson's philosophical intuitionism, Sorel reinterpreted the Marxist class struggle in mythological terms, challenging all forms of rationalist political thought. For the French theorist of proletarian revolution, all significant historical change is triggered, not by intellectual constructions, but by powerful action-inducing myths. From antiquity to the French Revolution, Sorel sees myths as having provided the courage for violence and self-sacrifice that every great historical mission requires. Now, in the conditions that prevail in modern industrial society, Sorel sees the proletariat as the transformative myth-carrying class. Its myth, however, is not a dialectical conception of the class struggle vindicated a priori by the impersonal force of historical necessity, but rather a fundamentally irrational belief in an imminent, insurrectionary general strike that will bring about the collapse of the capitalist order. This eschatological belief stems directly from the proletarian instinct, from unreflective proletarian experience under industrial capitalism. Schmitt's (1988: 66-72) examination of Sorel's ideas gives the impression of unbiased objectivity, at times even bordering on the appraisive, but towards the final pages of the booklet, a crucial twist in the argument takes place. Schmitt (1988: 72), indeed, sees in Sorel's mythical reading of the class struggle inherent 'organic contradictions,' meaning that the Frenchmen's syndicalist myth is built upon the mythically infertile grounds of rationalistic and mechanized capitalist production. 'Just like the bourgeois,' he argues, the proletarian 'will be forced, through the superior power of the production mechanism, into a rationalism and mechanistic outlook that is empty of myth' (Schmitt, 1988: 73). The great merit of Sorel's reinterpretation of the class struggle lies, thus, not in its destructive - anarchist and atheist-implications, but in the rediscovery of the significance and power of myths per se, thus paving the way for other political mythologies, which, contrary to Sorel's 
own, prove reconcilable with the principles of authority, order and hierarchy. The alternative, 'stronger myth' is that of the nation, which draws on deeper ethnic, linguistic and telluric sources for a surplus of 'energy' that generates an even more threatening picture of the political enemy than the proletarian depiction of the despicable bourgeois (Schmitt, 1988: 75). This, he continues, had been confirmed by the Bolshevik revolution, which - as Sorel himself appeared to admit - could only triumph because it combined Russian nationalism and anti-Western sentiment with communist doctrine. Still, even more decisive was Mussolini's recent rise to power in Italy:

Until now the democracy of mankind and parliamentarism has only once been contemptuously pushed aside through the conscious appeal to myth, and that was an example of the irrational power of the national myth... Just as in the sixteenth century, an Italian has once again given expression to the principle of political realism. The meaning in intellectual history of this example is especially great because national enthusiasm on Italian soil has until now been based on democratic and constitutional parliamentary tradition and has appeared to be completely dominated by the ideology of AngloSaxon liberalism.

(Schmitt, 1988: $75-76)^{74}$

The conclusion that The Crisis of Parliamentary Democracy boils down to a eulogy of Italian fascism is, hence, not unwarranted. Even if he had misgivings about fascist economic organization as a stato corporativo, Schmitt never wavered in his admiration for Mussolini. ${ }^{75}$ However, he did have some reservations on whether fascism's galvanization of 'the irrational power of the national myth' was the last word on how to establish the necessary connection between the sovereign dictator and the immanent source of his authority. In the very last paragraph of the tract, Schmitt (1988: 76) expresses apprehension concerning the danger that order and unity might 'be destroyed in the pluralism of an unforeseeable number of myths.' The threat posed by pluralism to state authority and political unity was already acutely perceived by Schmitt, though he would only arrive at a definitive answer to this problem in the context of his reflections on The Concept of the Political, elaborated from 1927 onwards. If one may borrow here from a 1918 essay by Georg Simmel—which, incidentally, appeared in the same series of brochures as the second edition of Schmitt's critique or parliamentary democracy ${ }^{76}$-it appears Schmitt realized that the political theory of myth amounted to a hopeless, and potentially destructive, rebellion of life 'against form itself, against the principle of form' (Simmel, 1999: 185). Sovereign-dictatorial action should not merely aim to do away with an inadequate political form, but rather pave the way for a new, adequate one. Fascism's emphasis on the power 
of nationalist mythology was perhaps too thin, and its lack of concern for appearing "democratic" too careless (Schmitt, 1988: 30), to serve as minimally solid grounds for political authority in the modern age. Such a foundation, according to Schmitt's narrative of secularization, must be based on, and understood in light of, a theory of democratic legitimacy. Thus, notwithstanding its irrationalist allure, the political theory of myth turned out to be an inconsequential episode in Schmitt's political thought. His neo-authoritarian vision would have to be complemented by a more elaborate account of its immanent foundations.

\section{From Myth to Substance: Democratic Equality as Homogeneity}

Already in his study on Dictatorship, Schmitt (1921: 144) had referred to the nation as 'the substance of the state' (die staatliche Substanz) in connection with his interpretation of Sieyès's notion of the pouvoir constituant as the amorphous source of all political forms. However, what this idea of a "substance" of the state more concretely means, and what its implications are, gains some clarity only when Schmitt begins to flesh out his theory of democracy. In contrast to most pro-Weimar political thinkers and constitutional theorists, Schmitt took the concept of equality, rather than that of freedom or some combination of the two ideas, to be the cornerstone of democracy. ${ }^{77}$ However, contrary to what liberal minds assumed, the basis of democratic equality was not the idea of a universally shared humanity as grounds for equal political rights, but rather that of belonging to a particular human group which is willing to assert its political existence. Democratic equality, for Schmitt, pertains not to abstract, universal humanity, but to the concrete homogeneity of the discrete political unit. This conception of equality is unambiguously argued for in the preface to the second edition of The Crisis of Parliamentary Democracy, published in 1926, where its, according to Schmitt, unavoidable correlate is clearly stated:

Every actual democracy rests on the principle that not only are equals equal but unequals will not be treated equally. Democracy requires, therefore, first homogeneity and second - if the need ariseselimination or eradication of heterogeneity.

(Schmitt, 1988: 9)

Far from being just a theoretical possibility, the 'eradication of heterogeneity' was conceived as an actual necessity for modern democracies emerging under increasingly complex social conditions. The pluralist idea that democracy is about fostering compromises between heterogeneous groups co-existing within the territory of a state was flatly rejected by Schmitt, who refers to the agreements between Turkey and Greece, which resulted in the forced displacement of two million people after the 
First War, as impeccably democratic means of enforcing homogeneity. In this context, he notes that homogeneity, in the modern age, stems mainly from membership in a particular nation. Democratic equality meant, thus, national homogeneity. However, Schmitt also adds that in previous, pre and early modern democratic experiences, other sources of homogeneity were used to include individuals in, and excluded them from, the demos. The basic point about equality, for Schmitt (1988: 9), is that it 'is only interesting and valuable politically so long as it has substance, and for that reason at least the possibility and the risk of inequality.'

A more thorough examination of Schmitt's conception of substantial equality requires a close reading of key instances of his most voluminous work, Constitutional Theory, originally published in 1928. For here-and only here - does the author outline, in seemingly non-polemical terms, a theory of democracy. The work presents itself as a systematic treatment of the constitutional theory of the bourgeois Rechtsstaat as the general type to which the Weimar constitution belongs (Schmitt, 2010: xi-xiii). Again, we have a four-partite structure, but here, in contrast to Political Theology and The Crisis of Parliamentary Democracy, there is no powerfully orchestrated crescendo in the last section, revealing Schmitt's fundamental positions and the stark dichotomies upon which they rest. In fact, as Schmitt clearly points out in the preface, the crucial tension is located at the very core of the book, ensuing from the distinction between, on the one hand, the Rechtsstaat component of the modern constitution (part two) and, on the other hand, what the author views as its properly political component (part three):

A special difficulty for the constitutional theory of the bourgeois Rechtsstaat lies in the fact that even today the bourgeois-constitutional component is still confused with the entire constitution, although in truth it cannot stand on its own, but only add to the political component. That one-purely fictitiously-equates the principles of the bourgeois Rechtsstaat with the constitution in general has led to the disregard or misjudgement of essential processes of constitutional life. The treatment of the concept of sovereignty has suffered most from this method of fiction and ignorance.

(Schmitt, 2010: xiii-xiv) ${ }^{78}$

That this distinction between the two components of a modern constitution is not neutral, that Schmitt does not merely aim to distinguish them analytically, but rather to assert the superiority of one over the other, can be inferred from the fact that the author deems the bourgeoisconstitutional component capable only of adding to a purportedly more fundamental political component. The latter is not treated as equivalent to the constitution as a whole, but it is indeed equated with a 'positive,' as opposed to a 'relative,' concept of the constitution 'as an overall decision on the type and form of political unity' (Schmitt, 2010: 20). ${ }^{79}$ 
For most of the treatise, however, Schmitt adopts a scholarly mode of presentation and his opposition to the liberal-bourgeois Rechtsstaat in general, and to the Weimar constitution in particular, remains mostly hidden between the lines, generating accrued difficulties to the interpreter. Beaud (1995) proposes an extensive reading of Leo Strauss's notion of "art of writing" as a useful heuristic tool to handle these difficulties. Strauss (1952), to be sure, developed the notion drawing on his studies on ancient and medieval philosophy. As regards the moderns, he considered it 'comparatively easy to read between the lines of their books' (Strauss, 1952: 34), and he was rather wary of having his notion confounded with a Mannheimian sociology of knowledge approach. Furthermore, he argued that the 'exoteric literature' he was surveying was 'essentially related to a society which is not liberal' and doubted that it would make much sense to employ the notion of "art of writing" 'in a truly liberal society' (Strauss, 1952: 36). Nevertheless, Beaud (1995: 26-36) makes a compelling case for applying the concept to Schmitt's Constitutional Theory as a rather unusual instance of an authoritarian thinker seeking to adjust to the constraints of a liberal regime. He does so by specifying that the constraints Schmitt was facing were neither political nor intellectualthere was full freedom of speech in the Weimar Republic and the general intellectual mood was in fact anti-liberal-but rather professional. Schmitt was writing a handbook on constitutional doctrine, which he hoped would become standard reading, and thus further his academic career, in German law faculties under the prevailing constitutional order. This made him avoid formulating a direct critique of the Weimar regime, as he had done and would continue to do in many shorter tracts, articles and pamphlets. 80

Now, while Beaud, as a legal scholar, was principally focused on Schmitt's "art of writing" qua professional jurist, our interest in Schmitt as a political theorist leads us to underscore a particular technique of his "art of writing" which the French professor of constitutional law overlooked. In what follows, our discussion of Constitutional Theory concentrates on how Schmitt uses the ideas of a liberal thinker both as a vehicle to present and as a mask to hide his own eminently authoritarian thinking. More precisely, we will show how, in two different but interrelated ways, Schmitt's highly selective reading of Sieyès's constitutional and political thought serves to put forward his own views on democracy, state and constitution-making, and the nature of political community.

Schmitt's first move in reinterpreting Sieyès for his own purposes builds upon his earlier reflections on the pouvoir constituant as the basis for a sovereign conception of dictatorship. In the first part of Constitutional Theory, which reviews different understandings of the term "constitution," Schmitt (2010: 75) defines constituent power as "the political will, whose power or authority is capable of making the concrete, comprehensive decision on the type and form of its own political existence. ${ }^{, 81}$ From 
this definition, the author follows (1) that the constitution rests upon an existential will — not a norm - which is the ground of its validity; (2) that constitutional legislation executes this constituent will; (3) that the constituent will is inexhaustible and inabsorbable, remaining at all times alongside and above the constitution; and (4) that the constituent power is one and indivisible (Schmitt, 2010: 76-77). What we have here is, in essence, a radicalization of Sieyès's idea that the constitution rests on the will of the nation as the subject of the constituent power. Sieyès's (2002: 55) oft-cited phrase - '[i]n whatever manner a nation wills, it suffices that it does will ${ }^{82}$ - is severed from the individualist premises of the Abbé's political thinking and taken to imply that the will of the nation is the absolutely boundless 'source of all power' (Schmitt, 2010: 79). Granted that, for Sieyès, all positive laws and all constituted powers yield irresistibly to the will of the nation as soon as it appears, the latter nonetheless remains bound by the laws of nature and reason. The primacy of natural law, rooted in the individual, vis-à-vis both positive law and the collective will of the nation is firmly asserted by the French thinker. After all, the will of the nation is no more than the mechanical sum of individual volitions, just as the nation itself is nothing more than a gathering of individuals who join together - and these are, for Sieyès (2002: 73), the only conceivable purposes of a 'legitimate association'-to mutually guarantee their security, property and freedom. In characteristically liberal fashion, Sieyès derives the collective will of the nation and its constituent power from the inalienable natural rights of the individual, whereas Schmitt uses the concept of the pouvoir constituant to denote the inexhaustible power of an uncaused collective being - the nation or the people - which precedes and fully absorbs the individual (Breuer, 1984: 510-511).

If, in his first move, Schmitt developed an absolutizing, antiindividualist concept of the nation against both the letter and the spirit of French revolutionary doctrine, the second move consists of accentuating the particularistic dimensions of the national political community against the idea that democracy would constitute a universal human aspiration. For that purpose, he draws on a conceptual distinction between people (Volk) and nation. In a first instance, he notes that the word Nation should be used to refer to the subject of the constituent power because it 'is clearer and less prone to misunderstanding' a concept. While Volk can also refer to a politically amorphous ethnic or cultural entity, nation 'denotes, specifically, the people as a unity capable of political action' (Schmitt, 2010: 79) endowed with a will that by itself generates political forms. ${ }^{83}$ In a second instance, expounding on his theory of democracy, Schmitt (2010: 231) specifies the concept of the nation '[i]n contrast to the general concept of the people. ${ }^{.84}$ The aim here is to distance democracy from the Enlightenment ideals of universal humanity and brotherhood of peoples, making it appear as a political form that rests on the sovereignty of a particular, fully homogeneous people. 
For Schmitt, what triumphed in 1789 were not the lofty ideals of the philosophes, but the French nation as a concrete political entity, laying the basis for the development, in the course of the nineteenth century, of a principle of democratic rule based on national homogeneity. From this theory of national democracy follows, first, that where homogeneity is lacking, it must be enforced, and second, that peaceful means of achieving it are just as legitimate, from a democratic point of view, as more radical or even ostensibly violent ones. For without homogeneity, there is no state, no political unity (Schmitt, 2010: 231-234).

Müller (1997: 27) has pertinently remarked that 'Schmitt thought the nation from the vantage point of the state.' Indeed, far from subscribing to the standard, nineteenth-century nationalist thesis that every nation should become a state, Schmitt's theory of democracy reasons the other way around. As long as national homogeneity constitutes the substance from which political unity is drawn - and only for so long - the state must mould its subjects accordingly and prevent the intrusion and development of any unity-dissolving foreign elements. The fact that, in modern democracies, legitimate power must be referred back to a worldimmanent source in no way alters the necessity of a strong authoritarian state. Even if a pure democracy, as Rousseau theorized it, would entail unanimity, perfect identity and a 'minimum degree of government' (Schmitt, 2010: 215), in practice the modern state emerged in the form of absolute monarchy - thus, as pure representation - and Schmitt was firmly committed to the idea that no other structure could guarantee political unity in the modern world ${ }^{85}$ Liberal constitutionalism, with its attempts to limit and relativize state power, was hence conceived as a provisional condition of political indecision on the way from the negation of absolute monarchy to the acceptance of an equally absolute democracy. This neo-absolutist democracy would be based on the acclamation of the dictator who, by successfully laying claim to represent the constituent power of the people, elevates the modern masses to the status of political unity (Schmitt, 2010: 243-244). Indubitably, Schmitt's populism, his theory of the immanent popular foundations of modern political rule, was subsidiary and subservient to his neo-authoritarian decisionism.

\section{'The Political Is the Total'}

To round up our exposition of Schmitt's neo-authoritarian reinterpretation of modern democracy, some remarks on The Concept of the Political are mandatory. For it is in the context of the author's reflections on the specificity of the political that his critique of pluralism in domestic politics is most fully articulated, allowing one to grasp how Schmitt conceptualized the link between the political unity of the state and the international order. Furthermore, by taking into account the slight but not insignificant changes of emphasis in the different renditions of Schmitt's 
thesis, one can take a glimpse at the first traces of the author's transition from a neo-authoritarian position, built around the concept of state sovereignty, to a totalitarian stance which affirmed the state-transcending capacity of the Nazi movement.

According to Schmitt (1994: 75), his theses on The Concept of the Political originated in the seminars he held at the University of Bonn in 1925 and 1926. And indeed, a closer look at the preface to the 1926 edition of The Crisis of Parliamentary Democracy shows that the author's thinking on the distinctiveness of the political was already in motion (Schmitt, 1988: 11). ${ }^{86}$ The first, article-format version of the text was published in 1927, in the Archiv für Sozialwissenschaft und Sozialpolitik. In 1932, an enlarged and revised version appeared in a brochure format as part of a series of treatises and lectures published by Duncker \& Humblot, with Schmitt's Concept of the Political and The Crisis of Parliamentary Democracy featuring alongside Weber's Munich lectures and contributions by other renowned scholars (Simmel, Jellinek, Bergsträsser, among others). Finally, one year later, already after Hitler's Machtergreifung, Schmitt published another version, with several changes clearly motivated by the wish to adapt the text to the new political situation, in a Nazi publishing outfit based in Hamburg. It appears that already some contemporaries accused Schmitt of operating significant changes in the text, especially as regards the 1933 edition. ${ }^{87}$ Among recent commentators, Meier (1988, 2004: esp. 57-61), who investigates the differences between the three versions with philological meticulousness, sees Schmitt move from a focus on the autonomy of the political to an emphasis upon its intensity. Meier treats this shift as a reply to Leo Strauss's (1988) remarks on the 1927 text and as evidence for the distinction he establishes between Schmitt, the political theologian oriented at the core of his thought by faith in revelation, and Strauss, the rational political philosopher in the ancient Greek tradition. More recently, however, Scheuerman (2007) has shown that Schmitt took the idea that the concept of intensity (Intensität) was crucial for determining the political, without acknowledging the junior colleague, from Hans Morgenthau's 1929 Leipzig dissertation. In any case, I think that both Meier and Scheuerman exaggerate the extent of Schmitt's shift from the 1927 to the 1932 and 1933 versions of The Concept of the Political. If one disregards the shameless lip service Schmitt pays to the Nazis in some additions to the 1933 text, what occurs between the earlier and the later versions, quite similarly to what we contended earlier concerning the differences between Dictatorship and Political Theology, is a change in tone and a sharpening of the formulations, rather than a fundamental shift in position. Only that in this case such rhetorical sharpening brings out the most ominous potentialities of Schmitt's thought.

At the centre of the 1927 version of The Concept of the Political is the problem of pluralism and the threat it poses to political unity. According to Schmitt, French syndicalists and British Fabian socialists had 
taken pluralistic political theory to its utmost unity-dissolving consequences. They rejected to conceive the state as a sovereign unit(y) and emphasized instead — especially the British pluralists - each individual's simultaneous belonging to a variety of social associations and connections. ${ }^{88}$ However, in doing so, they were merely evading the question of "which "social entity"...decides the extreme case and determines the decisive grouping according to friend and enemy' (Schmitt, 1963: 43; 1994: 76). ${ }^{89}$ The distinction between friend and enemy constitutes, thus, the specific criterion of the political, setting it apart from other relatively independent spheres of thought and practice equipped with their own meaning-generating binomials (good and evil for ethics, profitable and unprofitable for economics, beautiful and ugly for aesthetics, and so on) (Schmitt, 1933: 7; 1963: 26-27; 1994: 77). In other words, grouping human beings into friends and enemies is, for Schmitt, the specifically political way of looking at the world. Against pluralist theory, Schmitt asserts that, in the modern world, the state is the only entity which can make this distinction, because it has the jus belli, the right to wage war and this amounts to an ultimate, borderline decision on the sacrifice of human lives. From this conceptual determination of the political, to be sure, pluralist consequences follow for the sphere of foreign politics. Implied by the friend-enemy distinction is 'the pluralism of states.' 'The political world is a pluriverse, not a universe' (Schmitt, 1963: 54; 1994: 81). ${ }^{90}$ The problem with pluralism at the domestic level, by contrast, is that the pluralistic forces of modern mass societies paralyse and weaken the state, making it incapable to decide and, thus, to impose authority and maintain order. The pluralistic stalemate - which, as Schmitt (1933: 14) praises, the Nazis had just broken in Germany-reduced the meaning of the political to party politics and condemned the state to irrelevance in the international arena. In sum, where party pluralism, with its impasses and compromises, prevailed, authority and political unity subsided:

The concept of the political has, however..., pluralistic consequences, but not in the sense that within the same political unit a pluralism could take the place of the decisive friend-enemy grouping without thereby destroying, along with the unity, the political itself.

(Schmitt, 1994: 78) $)^{11}$

Schmitt's critique of domestic, intrastate pluralism, with its assertion of state sovereignty as the basis in the absence of which 'the political itself' vanishes, suggests a nuanced interpretation of the famous, terse contention with which both the 1927 and the 1932 versions of the text opened: 'The concept of the state presupposes the concept of the political' (Schmitt, 1927: 1; 1963: 20). ${ }^{92}$ It is quite evident, on the one hand, that this claim is polemically directed against the positivist conception of nineteenth-century Staatslehre, according to which the state exhausted 
the terrain of the political, a conception which in a way Kelsen's positivism would radicalize by wholly equating state and law (Vollrath, 1989). On the other hand, however, it would be wrong to conclude from Schmitt's prioritization of the political that he goes one step beyond Weber's Politik als Beruf in relinquishing a state-centred understanding of the political. ${ }^{93}$ Indeed, in a certain sense, far from transcending a statist paradigm of the political, Schmitt actually reinforces it. As the modern vehicle of political unity, the state determines the eigentlich political decision between friend and enemy. Schmitt's Concept of the Political, thus, is resolutely opposed to the replacement of the state, the sovereign unit(y), by a fluid and contingent conception of power both as the material of political action and as the object of political thought and research-a move which, albeit not without hesitation, Weber had suggested roughly one decade earlier. ${ }^{94}$ For Schmitt, even if its definition hinges on the eventuality of war and violent revolution (i.e. civil war), the political aims at the assertion of unity, authority and order as properties of the sovereign state. In this regard, a footnote added to the 1933 edition is particularly clarifying, for there Schmitt opposes an agonal understanding of war to a properly political one, whose purpose is 'the establishment of rule, order and peace' (Schmitt, 1933: 10, n. 1). ${ }^{95}$ These stark neo-authoritarian implications of Schmitt's conception of state sovereignty are largely neglected by interpreters who recently have been drawing on Schmitt either for an agonistic renewal of the modern democratic project or for a theory of militant liberal democracy. ${ }^{96}$

Nevertheless, there are some passages both in the 1932 and, especially, in the 1933 editions of The Concept of the Political that can indeed be read as insinuating that Schmitt was already envisioning to take the political beyond its modern, state-sovereigntist circumstance. However, in my view, these should not be framed as a clear-cut shift in the conceptualization of the political from a "model of autonomy" in 1927 to a "model of intensity" in 1932 and 1933.

The passage usually singled out to prove that the alleged shift had occurred is from the 1932 edition:

The political can draw its strength from many different spheres of human life, from religious, economic, moral and other oppositions; it does not denote a separate subject area, but merely the degree of intensity [Intensitätsgrad] of an association or dissociation of human beings, whose motives can be religious, national (in the ethnical or cultural sense), economic or other...

$\left(\right.$ Schmitt, 1963: 38) ${ }^{97}$

Now, even if it is true that the specific word "intensity" (Intensität) was absent from the 1927 edition and that Scheuerman's claim that Schmitt took it from Morgenthau is most probably correct, the idea of intensity 
was already there to begin with as a key determinant of the political. The abundant use of the word "decisiveness" (Maßgeblichkeit) in the 1927 text as a feature of the friend-enemy distinction denotes the very same sense of intensity (Schmitt, 1994: 76-78), and the terms are sometimes used interchangeably in the later editions. For instance, in 1933, Schmitt refers both to the autonomy (Selbständigkeit) and to the decisiveness (Maßgeblichkeit) of the friend-enemy criterion (Schmitt, 1933: 9). ${ }^{98}$ Meier, in turn, calls his readers' attention to those passages in the later editions which, according to him, suggest a theological intensification of the political. For example, when Schmitt (1933: 30) states that 'holy wars and crusades are actions that can be based upon a particularly deep and authentic decision of enmity, ${ }^{, 99}$ or when he refers to a war speech by Oliver Cromwell which can be taken to imply that modern enmity, typically dissociating human beings according to their national belonging (the strongest statecreating "substance" in the modern age), acquires greater intensity by being merged with a supposedly more fundamental distinction between believers and heretics (Schmitt, 1933: 48-49; 1963: 67). I believe, however, that this intensification is not in essence religious-theological, but rather a hint at the impending move from a neo-authoritarian position to a totalitarian one, where the political, in an incessant movement, wholly absorbs every other distinction and connection between human beings. The turn towards the total state, which Schmitt (1931: 73-91) identified in one of his late Weimar writings as being either quantitative (state intervention in every sphere of activity) or qualitative (the state deciding each and every conceivable issue as sovereign), now gained a restless, comprehensive dimension. 'Man is completely and existentially taken in by political participation' (Schmitt, 1933: 21). ${ }^{100}$ While in this passage from The Concept of the Political, "total" and "sovereign" still stand side by side, the move from the latter to the former is already signalled. In the foreword to the 1934 reedition of Political Theology, Schmitt (2009: 7) announces its completion: 'In the meantime, we have come to recognize that the political is the total. ${ }^{101}$

\section{Final Remarks: Neo-Authoritarian Nihilism and the Occasionalist Closure of the People}

After Carl Schmitt embraced Nazism, a new selection of the "substance" of political unity quickly followed: Race was substituted for the nation and, at the same time, state sovereignty gave way to the racist imperialism of the totalitarian movement (Schmitt, 1935). The reader of Schmitt's Weimar-era writings, where the notion of race does not appear once as a possible source of political unity, is surely tempted to interpret Schmitt's conversion to Nazi racism as a display of sheer opportunism. However, as Löwith persuasively argues in an essay - composed in exile and originally published in 1935 under the pseudonym "Hugo Fiala"- that should 
be mandatory reading for every Schmitt scholar, it would be theoretically careless to treat such an opportunism simply as a matter of ruthless personal ambition and moral failure, for it proceeds from the very structure of Schmitt's thought. Returning the charge of occasionalism, which Schmitt had levelled against the romantics, back to Schmitt himself, Löwith (1984: 38) shows that his interwar political thought was inherently permeable to whichever "substance" could be harnessed to fill the void of the neo-authoritarian 'decision for decisiveness' (Entscheidung für die Entschiedenheit). ${ }^{102}$ The content of the Schmittian decision is indeed the product of the 'purely accidental occasio of the given political situation' (Löwith, 1984: 40), ${ }^{103}$ and what results from it is ultimately an intensified variety of political absolutism, freed from all traditional limitations in its quest for unity through, if necessary, violently enforced homogeneity. The nihilistic denouement of Schmitt's neo-authoritarian vision is a paradigmatic instance of the difficulties involved in decoupling the concept of authority in general, and of political authority in particular, from a tradition which precedes and exceeds its personal carriers. More fundamentally, perhaps, it is also an indication that the modern age, as Arendt (1954) keenly suggests, is inhospitable to the very idea of authority.

Finally, if one takes the concept of the people as the most general term in Schmitt's thought to designate the immanent source of modern political rule, one must conclude that it aims at full closure, on whichever grounds. This closure, entirely contingent upon the existing political occasion, is brought about by the neo-authoritarian leader, who exploits some feature or features of the people to determine and enforce its homogeneity. It is, thus, with good reason that a Schmitt scholar like J.-W. Müller (2016: 52), in his recent book on populism, quotes from Constitutional Theory to warn us of the danger that present-day populist movements pose, not just to liberal democracy, but to democracy tout court-or, perhaps more precisely, to modern democracy as a political formation that, to use Lefort's (1988: 19) illuminating words, 'is instituted and sustained by the dissolution of the markers of certainty. ${ }^{104}$ For present-day populists - with their essentialist nationalisms, their politicization of religion and "traditional values," their moral denigration of "foreign elites," and so on - are basically performing a Schmittian operation of populist closure. If, against a solipsistic methodological individualism, one wishes to retain the concept of the people as a crucial component of democratic thought, one must refrain from turning it into a mystical entity, endowed with a mythical, unified will. This means that the identity of the collective subject of modern democratic rule, despite the ineradicable longing for wholeness that has fuelled its greatest historical achievements, must remain indeterminate and open to contestation. Notwithstanding its caveats and limitations, the pluralist democratic theory of Hans Kelsen, to which we turn next, allows one to think further in that direction. 


\section{Notes}

1 Stolleis (2004: 18) points out that Gesetz und Urteil 'marked the first appearance of the "decision" (Dezision) as a validating and norm-creating factor.' Hofmann (1995: 32-39) and Caldwell (1997: 52-53) also emphasize the importance of this early work, with its insistence on the inherent juristic value of decisions as such, irrespective of the reasons adduced to justify them, as a precursor of Schmitt's authoritarian political thought. Schmitt (1921: xi) makes reference to it in the preliminary remarks to his monograph on dictatorship.

2 For a prime example, see Windelband's posthumously published Geschichtsphilosophie (1916). Yet, Windelband was not alone in this; in fact, among the most prominent neo-Kantians, Ernst Cassirer was the only one who did not engage in philosophical war propaganda. Thus, after the war, it was up to him to defend the neo-Kantian legacy, which he sought to frame as republican and democratic, from the manifold attacks of a disillusioned younger generation of philosophers - a fight he would end up losing (Beiser, 2013).

3 In an epigrammatic periodization of his own trajectory, penned at the age of 70, Schmitt (2015: 370) traces the Catholic influence to his childhood, spent among priests with Kulturkampf memories, while his youth years (1907-1918) bear the marks of 'de-Hegelianized' Wilhelmine Prussianism and neo-Kantianism.

4 Schmitt mentions Rudolf Stammler, Paul Natorp and Hermann Cohen, but only the first two are explicitly quoted.

5 A charge which, as we will have the opportunity to point out in the next chapter, he would later direct at Hans Kelsen's concept of the Grundnorm.

6 'Der Wert im Recht und in dem Mittler des Rechts, im Staat, bemißt sich demnach nur nach den Normen des Rechts, nicht nach Dingen, die dem Einzelnen endogen sind.'

7 This should not be taken to imply that the neo-Kantian influence on Der Wert des Staates was only superficial and perhaps negligible. The particular condition of neo-Kantian philosophy at the time suggests a more nuanced perspective. Indeed, Beiser (2009) argues that the philosophical problems encountered by the neo-Kantian concept of normativity led many of its proponents (Windelband, Rickert and Lask) to paradoxically return to metaphysics in general, and Hegel in particular, on the eve of the First War. Schmitt's effort to bridge the gulf between the spheres of norms and facts by emphasizing the role of the state could, hence, be read as entrapped in the very demise of the neo-Kantian concept of normativity.

8 A misconception nurtured, for instance, by Balakrishnan (2000: 17), who speaks of an 'abrupt shift to the Right which took place in the early Weimar years.'

9 In the very passage that Rogers (2016: 133, n. 44) invokes to sustain his liberal interpretation, Schmitt says very clearly that, from a legal-scientific perspective, the individual should not be understood as an 'autonomous instance of legislation': 'Andere Beurteilungsweisen können für das Individuum einen andern Wert ergeben, in ihm auch eine autonome Instanz für eine Gesetzgebung erblicken; für eine rechtswissenschaftliche Betrachtung ist jedoch die strengste Heteronomie aller rechtlichen Normen das einzige, was in dieser Angelegenheit entscheidet...' (Schmitt, 1914: 3). This can at most be read as an endorsement, by Schmitt, of Kelsen's notion of the objective nature of law as opposed to the subjective nature of ethics-by 1914, Schmitt had not yet drifted as far away from Kelsen's normativism as he would in the interwar period-but not as a commitment to liberal values. 
10 Walter Rathenau was an industrialist of Jewish origin, son to the founder of the electrical company AEG, who also pursued an intellectual and political career. The cultural critique elaborated in his writings, most notably in Zur Kritik der Zeit (1912), which bemoans the mechanization of human life and calls for a return to spirituality, has evident affinities with the sort of conservative cultural pessimism that would climax in Oswald Spengler's Decline of the West (1918). He was a rather ambivalent figure, whose philosophical diagnosis of the age veered to the conservative right, while his economic and political activities swerved to the liberal left. In 1922, shortly after the signing of the Treaty of Rapallo with the USSR, which he negotiated as the German foreign minister, Rathenau was assassinated by a far-right terrorist group. For a recent biographical account, see Volkov (2012).

11 That modernism was a politically diverse artistic movement in its penchant for radicalism is as true for Schmitt's Munich as it was for any other major centre of modernist art across Europe. On the Munich scene, with an emphasis on the political aspects of radical literary culture, see most recently Weidermann (2018).

12 'Zuerst ist das Gebot, die Menschen kommen später.'

13 'Dies Zeitalter hat sich selbst als das kapitalistische, mechanistische, relativistische bezeichnet, als das Zeitalter des Verkehrs, der Technik, der Organisation' (Schmitt, 1916: 59).

14 'Sie wollen den Himmel auf der Erde, den Himmel als Ergebnis von Handel und Industrie, der tatsächlich hier auf der Erde liegen soll, in Berlin, Paris oder New York, einen Himmel mit Badeeinrichtungen, Automobilen und Klubsesseln, dessen heiliges Buch der Fahrplan wäre. Sie wollen keinen Gott der Liebe und Gnade, sie hatten so viel Erstaunliches „gemacht", warum sollten sie nicht den Turmbau eines irdischen Himmels „machen“. Die wichtigsten und letzten Dinge waren ja schon säkularisiert. Das Recht war zur Macht geworden, Treue zur Berechenbarkeit, Wahrheit zur allgemein anerkannten Richtigkeit, Schönheit zum guten Geschmack, das Christentum zu einer pazifistischen Organisation. Eine allgemeine Vertauschung und Fälschung der Werte beherrschte die Seelen. An die Stelle der Unterscheidung von gut und böse trat eine sublim differenzierte Nützlichkeit und Schädlichkeit.'

15 'Die Menschen, die sich von ihm [dem Antichrist] täuschen lassen, sehen nur den fabelhaften Effekt; die Natur scheint überwunden, das Zeitalter der Sekurität bricht an; für alles ist gesorgt, eine kluge Voraussicht und Planmäßigkeit ersetzt die Vorsehung; die Vorsehung „macht“ er, wie irgendeine Institution.'

16 'Der Geist besiegt den Zweifel; die letzte Negation ergibt die Überwindung aller Relativität, die Transcendenz.'

17 For a thorough analysis of the Nordlicht monograph, see Breuer (2012: $25-$ 31). Kennedy (2004: 40-47) places Schmitt's early literary works insightfully in the context of the expressionist generation of 1910.

18 Schmitt's reasoning is indeed at the antipode of the argument that the philosopher of Königsberg develops in his famous article 'On the Common Saying: "This May Be True in Theory, but it Does not Apply in Practice" (Kant, 1991: 61-92).

19 'Die rechtliche Behandlung des rein tatsächlichen Zustandes einer konkreten Gefahr erfolgt also in der Weise, daß vom Recht ein rechtsfreier Raum abgesteckt wird, innerhalb dessen der Militärbefehlshaber jedes ihm geeignet erscheinende Mittel anwenden darf.'

20 For excellent analyses of Schmitt's wartime legal articles, see Caldwell (1997: 54-62) and Rogers (2016: 134-141). 
21 Schmitt's thesis on the apolitical 'occasionalism' of romantic intellectuals was very well received by prominent Marxists and progressives. Lukács (1968) endorsed it almost enthusiastically in a 1928 review and Mannheim (1954: 56, n. 4), who also considered Schmitt's analysis of parliamentary political institutions more adequate than Marxism's, makes a positive reference to it in Ideology and Utopia (1929). In fact, the relationship between Mannheimian sociology of knowledge and Schmitt's analysis, not only of liberalism as a 'comprehensive metaphysical system' (Schmitt, 1988: 35), but also of German conservatism-Mannheim's (1954: 208-209) interpretation of Hegel as a historicist conservative bears striking similarities with Schmitt's (1986: 64) - is a topic that has not yet been studied in depth. In any case, however, both Lukács and Mannheim failed to notice, or at least to point out, Schmitt's unambiguous siding with reactionary traditionalism in Political Romanticism.

22 The fact that Schmitt starts his historical genealogy of the modern state with a decisive institutional development within the Catholic Church is yet again proof of what we referred to earlier as his "formal" Catholicism, which took Church hierarchy as the model for political representation. Weber, too, as noted in the previous chapter (n. 36), traced the beginnings of Church bureaucratization to the thirteenth century. On the concept of plenitudo potestatis, papal and imperial, see Schmidt (1999).

23 The reason for this was possibly to cleanse the term from a pejorative connotation. On Schmitt's selective use of the Roman historical tradition on dictators, see Tuori (2016).

24 'Im 18. Jahrhundert erscheint zum ersten Male in der Geschichte des christlichen Abendlandes ein Begriff der Diktatur, nach welchem der Diktator zwar Kommissar bleibt, aber infolge der Eigenart der nicht konstituierten, aber konstituierenden Gewalt des Volkes ein unmittelbarer Volkskommissar, ein Diktator, der auch seinem Auftraggeber diktiert, ohne aufzuhören, sich an ihm zu legitimieren.' Unfortunately, M. Hoezl's and G. Ward's translation of Dictatorship mixes up the key notions of constituent and constituted power in this instance (see Schmitt, 2014: xliv).

25 The choice of protagonists shows clearly that Schmitt's narrative, despite the digressions across the Channel and the Rhine, as well as over the Alps and (though less frequently) the Pyrenees, is French-centred. Indeed, if one were pressed to define Schmitt as a specialist, based on his two most scholarly works (Dictatorship and Constitutional Theory), one would have to emphasize above all his in-depth knowledge of French political thought and constitutional history. A contemporary like Eric Voegelin (2001: 42), for instance, points this out in a lengthy and mostly appraisive review of Constitutional Theory published in 1931.

26 'Auch die Lehre vom pouvoir constituant ist als bloß mechanistischer Rationalismus unbegreiflich. Das Volk, die Nation, die Urkraft alles staatlichen Wesens, konstituiert immer neue Organe. Aus dem unendlichen, unfaßbaren Abgrund ihrer Macht entstehen immer neue Formen, die sie jederzeit zerbrechen kann und in denen sich ihre Macht niemals definitiv abgrenzt.'

27 Emphasis added on always.

28 See Chantal Mouffe's (1999) edited volume for a collection of essays that engage Schmitt from a left-wing perspective.

29 For a thought-provoking discussion of 'the denigration of the masses' in the crowd psychology of Gustave Le Bon and others, see Laclau (2005: 21-52). For a historical perspective on bourgeois class anxiety in the early twentieth century, see Maier (1988: 22-39). 
30 The sociology of the state, which Weber did not live long enough to complete, would perhaps have provided a fitting occasion for a thorough engagement with the question of sovereignty. In any case, in Weber's political writings, which are often used as surrogates for the unfinished Staatssoziologie, the term pops up just as scarcely as in the sociological writings-and always without substantial theoretical elaboration.

31 The adjective "sovereign" surfaces twice in the lecture. In the first instance, within quotation marks, to argue that in a modern capitalist firm the "true "sovereign," the shareholders' meeting, has as little influence on the management of the business as a "people" governed by professional officials.' In the second case, without the quotation marks, in a reference to the 'sovereign ekklesia' of Periclean democracy (Weber, 1994: 326, 331).

32 Emphasis added on juristic. The concept of popular sovereignty, in turn, emerges once in Weber's analysis of the Western city, but it is immediately contrasted to the 'fact' that 'the notables were completely dominant' (Weber, 1978: 1266). Schmitt, in this regard, not only agreed with Weber's (1994: 174) oligarchical 'principle of the small number,' but in fact took it to its monoarchical, purely Caesaristic limits. See, for instance, his analysis of the Comité de salut public during the French Revolution: 'Here, too, the typical development occurred: the working Committee dominated the deciding assembly and in fact ruled, and then the influence of an individual slowly became decisive within the Committee... Robespierre dominated the Committee and the Committee dominated the Convention' (Schmitt, 1921: 151).

33 This is, I believe, the first appearance of the concept of homogeneity-and of the related problem of pluralism-in Schmitt's work. Both will play a central role in the development of his theory of democracy.

34 Kelsen is mentioned once in the 1921 monograph, by the end of a long footnote, in cautiously ambivalent terms. According to Schmitt (1921: 148, n.), Kelsen has authored the best critique of the communist concept of the dictatorship of the proletariat, but he failed to go to the crux of the question because he ignored the bigger picture - the bigger historical and theoretical picture of the concept of dictatorship which Schmitt's book intended to provide. Quite revealing, however, in a work where the idea of sovereignty plays such a crucial role, is the absence of any reference to Kelsen's (1928) methodological critique of sovereignty, originally published in 1920 .

35 An even shorter and equally polemical tract, written roughly at the same time.

36 An English translation of Colliot-Thélène's article has been reprinted in Mouffe (1999: 138-154).

37 These external circumstances, however, have been the source of some confusion in the secondary literature. Some argue that the three chapters were first and not later published in Palyi's Errinerungsgabe für Max Weber (Motschenbacher, 2000: 61), while others, labouring under the same misconception, make the absurd claim that 'a close reading of the original 1923 text' suggests 'that Schmitt's adversarial approach to Weber was formed earlier than has been acknowledged' (Engelbrekt, 2009: 670). Well, it was indeed formed earlier, since the original edition of Political Theology was published in 1922 and the three chapters republished therefrom in the Errinerungsgabe are almost word for word the same, with the exception of the insertion of a couple of paragraphs praising Erich Kaufmann's (1921) critique of neo-Kantian legal theory - that is what a careful close reading would have revealed.

38 'Souverän ist, wer über den Ausnahmezustand entscheidet.'

39 'Er entscheidet sowohl darüber, ob der extreme Notfall vorliegt, als auch darüber, was geschehen soll, um ihn zu beseitigen. Er steht außerhalb der 
normal geltenden Rechtsordnung und gehört doch zu ihr, denn er ist zuständig für die Entscheidung, ob die Verfassung in toto suspendiert werden kann.'

40 'Whoever masters the state of exception therefore masters the state, for he decides when this state should occur and what is then necessary depending on the situation.' ('Wer den Ausnahmezustand beherrscht, beherrscht daher den Staat, denn er entscheidet darüber, wann dieser Zustand eintreten soll und darüber, was alsdann nach Lage der Sache erforderlich ist.')

41 'Stets aber ist nach dem neuerem Sprachgebrauch eine Aufhebung der Demokratie auf demokratischer Grundlage für die Diktatur charakteristisch, so daß zwischen Diktatur und Caesarismus meistens kein Unterschied mehr besteht und eine wesentliche Bestimmung, nämlich das, was im Folgenden als der kommissarische Charakter der Diktatur entwickelt ist, entfällt.' Emphasis added. Hoelzl and Ward translate this passage accurately (Schmitt, 2014: xxxix).

42 McCormick (1998: 227) is perfectly aware that this reading is quite plausible, for he admits that the supposed transformation might already be suggested 'by the overall narrative thrust of Die Diktatur itself' - and decisively so, we add, by the framework provided by Schmitt's theory of secularization. In this regard, it should also be noted that Rogers (2016: 140) makes a strong case for tracing Schmitt's radical conception of sovereign dictatorship back to his wartime legal articles.

43 The passages Schmitt quotes can be found in Weber $(1922: 381,411)$.

44 Many years later, when he returned to the question of political theology in one of his last books, Schmitt (1970: 78) did not fail to notice this, referring to the crucial passage where Weber deems charisma 'the specifically creative revolutionary force of history' (Weber, 1978: 1117) as a paradigmatic example of conceptual secularization.

45 'Es muß eine normale Situation geschaffen werden, und souverän ist derjenige, der definitiv darüber entscheidet, ob dieser normale Zustand wirklich herrscht... Der Souverän schafft und garantiert die Situation als Ganzes in ihrer Totalität. Er hat das Monopol dieser letzten Entscheidung. Darin liegt das Wesen der staatlichen Souveränität, die also richtigerweise nicht als Zwangs- oder Herrschaftsmonopol, sondern als Entscheidungsmonopol juristisch zu definieren ist... Der Ausnahmefall offenbart das Wesen der staatlichen Autorität am klarsten.' Emphasis added.

46 'The norm proves nothing, the exception proves everything: not only does it confirm the rule, but the rule itself can only derive its existence from the exception. In the exception the power of real life breaks through the crust of a mechanism rigidified by repetition.' ('Das Normale beweist nichts, die Ausnahme beweist alles; sie bestätigt nicht nur die Regel, sondern die Regel lebt überhaupt nur von der Ausnahme. In der Ausnahme durchbricht die Kraft des wirklichen Lebens die Kruste einer in Wiederholung erstarrten Mechanik.')

47 George Schwab's translation of Political Theology, which in my view is inaccurate and problematic in several instances, renders this as 'a true exception' (Schmitt, 2005: 15).

48 'Die Verbindung von faktisch und rechtlich höchster Macht ist das Grundproblem des Souveränitätsbegriffes.'

49 'In der Sache ist das die alte liberale Negierung des Staates gegenüber dem Recht und die Ignorierung des selbständigen Problems der Rechtsverwirklichung.' 
50 Schmitt (2009: 35) suggests that Kelsen took his concept of form from Emil Lask's Kategorienlehre, published in 1911. This is a baseless assertion, given that Kelsen's neo-Kantian influences stem from the Marburg school-first and foremost, Hermann Cohen; to a lesser extent, Ernst Cassirer-not from the Southwest German or Baden school, to which Lask belongs. Actually, Kelsen was rather critical of the Baden school's philosophical grounding of the cultural sciences. See the next chapter for further references on this.

51 'Die Objektivität, die er für sich beansprucht, erschöpft sich darin, daß er alles Personalistische vermeidet und die Rechtsordnung auf das unpersönliche Gelten einer unpersönlichen Norm zurückführt.'

52 'In dem Gegensatz von Subjekt und Inhalt der Entscheidung und in der Eigenbedeutung des Subjekts liegt das Problem der juristischen Form. Sie hat nicht die apriorische Leerheit der transzendentalen Form; denn sie entsteht gerade aus dem juristisch Konkreten. Sie ist auch nicht die Form der technischen Präzision; denn diese hat ein wesentlich sachliches, unpersönliches Zweckinteresse.'

53 Incidentally, this is the crux of the argument that Voegelin (1936: ch. 6), a former student of Kelsen's who grew increasingly critical of his Doktorvater during the 1930s, develops at length in his The Authoritarian State.

54 'In der Begründung, die Kelsen seinem Bekenntnis zur Demokratie gibt, spricht sich die konstitutionell mathematisch-naturwissenschaftliche Art seines Denkens offen aus: die Demokratie ist der Ausdruck eines politischen Relativismus und einer wunder-und dogmenbefreiten, auf den menschlichen Verstand und den Zweifel der Kritik gegründeten Wissenschaftlichkeit.'

55 Schmitt's reference is again imprecise, but he is most likely referring to Weber's (2012: 185-226) long essay on Stammler's Economy and Law According to the Materialist Conception of History (1894), published in 1907. Weber (1922: 378-380) also tackles Stammler in his sociology of law, but not from the perspective of a critique of historical materialism.

56 'In ihrer konsequenten Manier ist das jene Art Soziologie, die man am besten der schönen Literatur zuweist, ein sozial-psychologisches „Porträt", dessen Verfahren sich von der literarisch-geistvollen Kritik, etwa von Sainte-Beuve, nicht unterscheidet.'

57 'Voraussetzung dieser Art Soziologie juristischer Begriffe ist also eine radikale Begrifflichkeit, das heißt eine bis zum Metaphysischen und zum Theologischen weitergetriebene Konsequenz. Das metaphysische Bild, das sich ein bestimmtes Zeitalter von der Welt macht, hat dieselbe Struktur wie das, was ihr als Form ihrer politischen Organisation ohne weiteres einleuchtet. Die Feststellung einer solchen Identität ist die Soziologie des Souveränitätsbegriffes.'

58 Missfelder (2006) argues that Koselleck was directly influenced by Schmitt's (1982) book on Hobbes's Leviathan, originally published in 1938.

59 'Heute dagegen kann ein bedeutender Staatsphilosoph wie Kelsen die Demokratie als den Ausdruck relativistischer, unpersönlicher Wissenschaftlichkeit auffassen. Das entspricht in der Tat der Entwicklung, die sich in der politische Theologie und Metaphysik des 19. Jahrhunderts durchgesetzt hat.'

60 A more prosaic reason for this is that the final chapter of Political Theology stemmed from a previous article published in an academic journal's special issue on Catholic legal philosophy (Fox, 2017: 25). In any case, in Dictatorship, there was already no reference to the British founder of modern conservatism. 
61 'L'état légitime est conforme à la volonté de la nature ou plutôt de son Auteur... L'état simplement légal est établi par la seule volonté de l'homme.' Bonald anticipates here the polemical use of the concept of legitimacy in opposition to that of mere legality, which Schmitt (1968) will exploit in a famous late Weimar writing. Yet, Bonald's conception of legitimacy is grounded in natural/divine law, not plebiscitary Caesarism.

62 'Schon in den zitierten Äußerungen von de Maistre lag eine Reduzierung des Staates auf das Moment der Entscheidung, konsequent auf eine reine, nicht räsonnierende [sic] und nicht diskutierende, sich nicht rechtfertigende, also aus dem Nichts geschaffene absolute Entscheidung.'

63 'Die im Gesetz liegende Entscheidung ist, normativ betrachtet, aus einem Nichts geboren. Sie wird begriffsnotwendig ,diktiert“. Aber die letzte Konsequenz dieser Gedanken wurde erst dann gezogen, als der Rationalismus erschüttert war, bei de Maistre.'

64 Schmitt (1986: 8) refers to an essay by Cortés on classicism and romanticism only in the preface to the second edition, from 1924.

65 'Jede politische Idee nimmt irgendwie Stellung zur „Natur" des Menschen und setzt voraus, daß er entweder ,von Natur gut" oder „,von Natur böse“ ist.'

66 In actual fact, Donoso Cortés, after being publicly accused of heresy, sought the judgement of the Holy See, whose official journal published a positive review of his Essays, which were later republished in Rome. His views were, thus, contrary to what Schmitt claims, theologically orthodox (Fox, 2017: 24).

67 On Schmitt's selective appropriation and mischaracterization of Donoso's views on dictatorship, see the excellent essay by Fox (2013). Yet, here one must point out that already Löwith (1984: 42) had alerted to Schmitt's blatant misinterpretation of Donoso - a fact which, unfortunately, Fox fails to mention.

68 'Heute ist nichts moderner als der Kampf gegen das Politische. Amerikanische Finanzleute, industrielle Techniker, marxistische Sozialisten und anarcho-syndikalistische Revolutionäre vereinigen sich in der Forderung, daß die unsachliche Herrschaft der Politik über die Sachlichkeit des wirtschaftlichen Lebens beseitigt werden müsse. Es soll nur noch organisatorisch-technische und ökonomisch-soziologische Aufgaben, aber keine politischen Probleme mehr geben. Die heute herrschende Art ökonomisch-technischen Denkens vermag eine politische Idee gar nicht mehr zu perzipieren. Der moderne Staat scheint wirklich das geworden zu sein, was Max Weber in ihm sieht: ein großer Betrieb.' Schmitt is probably alluding here to the analogies Weber $(1994: 315,326)$ drew in Politik als Beruf between the bureaucratic centralization of the modern state and the modern capitalist enterprise.

69 For a clear and thorough exposition of how Schmitt projects his own radically pessimistic anthropology upon the nineteenth-century Catholic reactionaries he claims to champion, whose views on original sin are rather more nuanced, see Fox (2017), who puts forward the bold claim, based upon the perusal of Schmitt's youth letters and diaries, that if the author is to be interpreted as a political theologian at all, rather than as a modern secular political theorist, then he ought to be interpreted as a Gnostic, not a Catholic, thinker. Löwith (1984: 68-70), in turn, suggests another possible source for-or at least an interesting parallel with-Schmitt's dismal view of human nature and its connection to a decision 'created out of nothingness,' namely, the pessimistic and anti-liberal turn in German-speaking Protestant theology in the aftermath of the First World War, spearheaded by Barth, Bultmann and Gogarten. The preliminary note to the second edition of Political Theology, from 1934, does indeed mention Gogarten, a 
Protestant theologian who, like Schmitt, endorsed Nazism (Schmitt, 2009: 7). For an overview of Protestant 'theologies of crisis' in the Weimar period, see Gordon (2013: 157-161).

70 The original title-Die geistesgeschichtliche Lage des heutigen Parlamentarismus, which one could render literally as The Intellectual-Historical Situation of Today's Parliamentarianism - waters down the polemical bite. In this case, E. Kennedy's option for a non-literal translation of the title, including the word "crisis," seems to me to be a rather felicitous choice, considering both the content and the general tone of the work.

71 By the way, Weber and Kelsen are here explicitly signalled out as intellectual foes (Schmitt, 1988: 24).

72 A term one had already encountered in the climax of the first chapter of Political Theology (Schmitt, 2009: 21).

73 In Dictatorship, Sorel is mentioned in a long footnote that emphasizes the turn towards irrationalism in late nineteenth-century European thought (Schmitt, 1921: 146-148, n.).

74 The reference to Machiavelli in this passage is particularly revealing, for it connects a practically oriented 'principle of political realism,' which in Dictatorship had been analysed in the context of a commissarial understanding of the concept, to an 'irrational power' which fuels a revolutionary, sovereign dictatorship.

75 For a more developed take of Schmitt on Italian fascism, see his review of E. v. Beckerath's Wesen und Werden des faschistischen Staates (1927), published in 1929 (Schmitt, 1994: 124-130).

76 Accompanied also by Weber's Politik als Beruf (Schmitt, 1988: xv).

77 In this respect, the liberal jurist Richard Thoma, in reply to whose review Schmitt wrote the long preface to the second edition of The Crisis on the contradiction between parliamentarism and democracy, is perhaps Schmitt's chief antagonist. See also Schmitt's (1994: 22-28) very critical review of Thoma's article 'Der Begriff der modernen Demokratie in seinem Verhältnis zum Staatsbegriff,' which appeared originally in the same volume in memory of Max Weber where Schmitt had republished the first three chapters of Political Theology. In any case, the continuing opposition to Hans Kelsen, upon whose pluralist democratic theory our next chapter will focus, must not be forgotten, for Kelsen (1920: 1-5) gave logical priority to the idea of freedom in his democratic thought.

78 'Eine besondere Schwierigkeit der Verfassungslehre des bürgerlichen Rechtsstaates liegt darin, daß der bürgerlich-rechtsstaatliche Bestandteil der Verfassung sogar heute noch mit der ganzen Verfassung verwechselt wird, obwohl er in Wahrheit sich nicht selbst genügen kann, sondern zu dem politischen Bestandteil nur hinzukommt. Daß man-rein fiktiv-die Prinzipien des bürgerlichen Rechtsstaates mit der Verfassung überhaupt gleichstellt, hat dazu geführt, wesentliche Vorgänge des Verfassungslebens außer acht zu lassen oder zu verkennen. Am meisten hat die Behandlung des Begriffes der Souveränität unter dieser Methode der Fiktionen und Ignorierungen gelitten.'

79 'Die Verfassung als Gesamtentscheidung über Art und Form der politischen Einheit.'

80 I disagree with Beaud, however, when it comes to his exaggerated emphasis on Schmitt's Catholicity and the extent to which it influenced his "art of writing."

81 'Verfassunggebende Gewalt ist der politische Wille, dessen Macht oder Autorität imstande ist, die konkrete Gesamtentscheidung über Art und Form der eigenen politischen Existenz zu treffen' (emphasis elided). 


\section{Neo-Authoritarian Populism}

82 'De quelque manière qu'une nation veuille, il suffit qu'elle veuille.'

83 'Nation und Volk werden oft als gleichbedeutende Begriffe behandelt, doch ist das Wort „Nation“ prägnanter und weniger mißverständlich. Es bezeichnet nämlich das Volk als politisch-aktionsfähige Einheit mit dem Bewußtsein seiner politischen Besonderheit und dem Willen zur politischen Existenz, während das nicht als Nation existierende Volk nur eine irgendwie ethnisch oder kulturell zusammengehörige, aber nicht notwendig politisch existierende Verbindung von Menschen ist.' (Emphasis in the original.)

84 'Nation bedeutet gegenüber dem allgemeinen Begriff Volk ein durch politisches Sonderbewußtsein individualisiertes Volk.'

85 On the important distinction between identity and representation as principles of political form, see Schmitt (2010: 204-216). For a thought-provoking discussion of representation and the problem of political form in Schmitt, see Mateo (2016: 89-129), who in my view delivers one of the few successful attempts by critical theorists to think with, beyond and against Schmitt.

86 It is worthwhile to cite here the relevant passage: 'In the domain of the political, people do not face each other as abstractions, but as politically interested and politically determined persons, as citizens, governors or governed, politically allied or opponents - in any case, therefore, in political categories. In the sphere of the political, one cannot abstract out what is political, leaving only universal human equality; the same applies in the realm of economics, where people are not conceived as such, but as producers, consumers, and so forth, that is, in specifically economic categories.'

87 In a short preliminary note added to the republication, in 1940, of parts of the 1927 text in the collection of essays Positionen und Begriffe, Schmitt states that the reprint allows the reader to judge the attempts made by unnamed 'emigrant magazines' to treat 'some improvements' he undertook later as 'indecent changes of mind' (Schmitt, 1994: 75).

88 The most complete formulation of Schmitt's critique of H. Laski's and G. D. H. Cole's pluralist theory is contained in his 1930 essay on 'Staatsethik und pluralistischer Staat' (Schmitt, 1994: 151-165).

89 "Aber damit ist die Frage noch nicht beantwortet, welche „soziale Einheit“" (wenn ich einmal hier den ungenauen, liberalen Begriff des „Sozialen“" übernehmen darf) den Konfliktsfall entscheidet und die maßgebende Gruppierung nach Freund und Feind bestimmt.' In the 1933 edition, this specific sentence disappears as a result of a more significant revision of the paragraph in question (Schmitt, 1933: 22-24).

90 'Aus dem Begriffsmerkmal des Politischen folgt der Pluralismus der Staaten. Die politische Einheit setzt die reale Möglichkeit des Feindes und damit eine andere, koexistierende, politische Einheit voraus. Es gibt deshalb auf der Erde, solange es überhaupt einen Staat gibt, immer mehrere Staaten und kann keinen die ganze Erde und die ganze Menschheit umfassenden Welt,,staat" geben. Die politische Welt ist ein Pluriversum, kein Universum.' The 1933 edition elides the first sentence from this passage (Schmitt, 1933: 35-36).

91 'Aus dem Begriff des Politischen ergeben sich allerdings, wie unten gezeigt werden soll, pluralistische Konsequenzen, aber nicht in dem Sinne, daß innerhalb der politischen Einheit an die Stelle der maßgebenden Freund- und Feindgruppierung ein Pluralismus treten könnte, ohne mit der Einheit auch das Politische selbst zu zerstören.' Emphasis in the original; the later versions change this passage slightly by switching from active to passive voice (Schmitt, 1933: 27-28; 1963: 45).

92 'Der Begriff des Staates setzt den Begriff des Politischen voraus.' In the 1933 edition, the opening sentence is an equally succinct ' $[\mathrm{t}]$ he real political distinction is the distinction between friend and enemy' ('Die eigentlich 
politische Unterscheidung ist die Unterscheidung von Freund und Feind.') (Schmitt, 1933: 7). In light of the new political situation, it might be that Schmitt thought the struggle with positivist jurisprudence was done and won, and so there was no need to insist on the priority of the political over and against (a legalistic understanding of) the state.

93 For a detailed analysis of Weber's views, see the previous chapter, pp. 34-36.

94 Therefore, Palonen's (2002: 19-20) excellent analysis of Politik als Beruf is entirely correct in its claim that Schmitt's Concept of the Political signified a far less radical break with the statist paradigm of politics than Weber's Munich lecture.

95 'Der große metaphysische Gegensatz agonalen und politischen Denkens tritt in jeder tieferen Erörterung des Krieges zutage... Hier vertrat Ernst Jünger das agonale Prinzip (,,der Mensch ist nicht auf den Frieden angelegt"), während Paul Adams den Sinn des Krieges in der Herbeiführung von Herrschaft, Ordnung und Frieden sah.'

96 Mouffe (2005), for instance, wishes to inject Schmitt's concept of the political into liberal democracies that have become torpid due to an excessive emphasis on a Rawlsian notion of consensus, but at the same time, she wants to avoid all the revolutionary and authoritarian implications that come attached to the concept. Even more problematic, still, is to reinterpret Schmitt as a partisan of constrained democracy, a sort of Praetorian Guard of Rawlsian liberal constitutionalism, as Schupmann's (2017) recent study suggests.

97 'Das Politische kann seine Kraft aus den verschiedensten Bereichen menschlichen Lebens ziehen, aus religiösen, wirtschaftlichen, moralischen und andern Gegensätzen; es bezeichnet kein eigenes Sachgebiet, sondern nur den Intensitätsgrad einer Assoziation oder Dissoziation von Menschen, deren Motive religiöser, nationaler (im ethnischen oder kulturellen Sinne), wirtschaftlicher oder anderer Art sein können...' Emphasis in the original; in slightly altered formulation in Schmitt (1933: 21).

98 'Das ändert nichts an der Selbstständigkeit und Maßgeblichkeit des politischen Gegensatzes.'

99 '...heiligen Kriege und Kreuzzüge sind Aktionen, die auf einer besonders echten und tiefen Feindentscheidung beruhen können.'

100 'Die politische Einheit ist infolgedessen immer, solange sie überhaupt vorhanden ist, die maßgebende Einheit, total und souverän. „Total“" ist sie, weil erstens jede Angelegenheit potenziell politisch sein und deshalb von der politischen Entscheidung betroffen werden kann; und zweitens der Mensch in der politischen Teilnahme ganz und existenziell erfaßt wird.'

101 'Inzwischen haben wir das Politische als das Totale erkannt...' On Schmitt as a theorist of the Nazi revolution, see the recent article by Suuronen (2020).

102 Emphasis in the original.

103 '...nur aus der zufälligen occasio der jeweils gegebenen politischen Situation...'

104 Emphasis in the original.

\section{References}

Arendt, H. (1954). Between Past and Future: Six Exercises in Political Thought, New York: Viking Press.

Balakrishnan, G. (2000). The Enemy: An Intellectual Portrait of Carl Schmitt, London: Verso.

Baume, S. (2009). 'On Political Theology: A Controversy between Hans Kelsen and Carl Schmitt,' History of European Ideas, Vol. 35, No. 3, pp. 369-381. 


\section{Neo-Authoritarian Populism}

Beaud, O. (1995). 'L'art d'écrire chez un juriste: Carl Schmitt,' in C.-M. Herrera (ed.), Le droit, le politique autour de Max Weber, Hans Kelsen, Carl Schmitt, Paris: L'Harmattan, pp. 15-36.

Beiser, F. C. (2009). 'Normativity in Neo-Kantianism: Its Rise and Fall,' International Journal of Philosophical Studies, Vol. 17, No. 1, pp. 9-27.

Beiser, F. C. (2013). 'Weimar Philosophy and the Fate of Neo-Kantianism,' in P. E. Gordon and J. P. McCormick (eds), Weimar Thought: A Contested Legacy, Princeton: Princeton University Press, pp. 115-132.

Bendersky, J. W. (1983). Carl Schmitt: Theorist for the Reich, Princeton: Princeton University Press.

Bonald, L. d. (1817). Pensées sur divers sujets, et discours politiques, Paris: Adrien Le Clère.

Bonefeld, W. (2017). 'Authoritarian Liberalism: From Schmitt via Ordoliberalism to the Euro,' Critical Sociology, Vol. 43, No. 4-5, pp. 747-761.

Breuer, S. (1984). 'Nationalstaat und pouvoir constituant bei Sieyès und Carl Schmitt,' Archiv für Rechts- und Sozialphilosophie, Vol. 70, No. 4, pp. 495-517.

Breuer, S. (2012). Carl Schmitt im Kontext. Intellektuellenpolitik in der Weimarer Republik, Berlin: Akademie Verlag.

Caldwell, P. C. (1997). Popular Sovereignty and the Crisis of German Constitutional Law: The Theory and Practice of Weimar Constitutionalism, Durham: Duke University Press.

Colliot-Thélène, C. (1995). 'Carl Schmitt contre Max Weber: rationalité juridique et rationalité économique,' in C.-M. Herrera (ed.), Le droit, le politique autour de Max Weber, Hans Kelsen, Carl Schmitt, Paris: L'Harmattan, pp. 205-227.

Engelbrekt, K. (2009). 'What Carl Schmitt Picked Up in Weber's Seminar: A Historical Controversy Revisited,' The European Legacy, Vol. 14, No. 6, pp. 667-684.

Fox, B. J. (2013). 'Schmitt's Use and Abuse of Donoso Cortés on Dictatorship,' Intellectual History Review, Vol. 23, No. 2, pp. 159-185.

Fox, B. J. (2017). 'Carl Schmitt and the Nineteenth-Century Catholic Reaction on Original Sin,' Telos, Vol. 178, pp. 9-32.

Gellner, E. (1983). Nations and Nationalism, Ithaca: Cornell University Press.

Gordon, P. E. (2013). 'Weimar Theology: From Historicism to Crisis,' in P. E. Gordon and J. P. McCormick (eds), Weimar Thought: A Contested Legacy, Princeton: Princeton University Press, pp. 150-178.

Heller, H. (2015). 'Authoritarian Liberalism,' European Law Journal, Vol. 21, No. 3, pp. 295-301.

Hofmann, H. (1995). Legitimität gegen Legalität. Der Weg der politischen Philosophie Carl Schmitts, Berlin: Duncker \& Humblot.

Holzhey, H. (ed.) (1994). Ethischer Sozialismus. Zur politischen Philosophie des Neukantianismus, Frankfurt am Main: Suhrkamp.

Kant, I. (1991). Political Writings, 2nd ed. (H. S. Reiss), trans. H. B. Nisbet, Cambridge: Cambridge University Press.

Kaufmann, E. (1921). Kritik der neukantischen Rechtsphilosophie. Eine Betrachtung über die Beziehungen zwischen Philosophie und Rechtswissenschaft, Tübingen: Mohr Siebeck.

Kelsen, H. (1920). Vom Wesen und Wert der Demokratie, Tübingen: Mohr Siebeck. Kelsen, H. (1928). Das Problem der Souveränität und die Theorie des Völkerrechts. Beitrag zu einer reinen Rechtslehre, 2nd ed., Tübingen: Mohr Siebeck. 
Kennedy, E. (2004). Constitutional Failure: Carl Schmitt in Weimar, Durham: Duke University Press.

Kierkegaard, S. (2009). Repetition and Philosophical Crumbs, trans. M. G. Piety, Oxford: Oxford University Press.

Köhnke, K. C. (1986). Entstehung und Aufstieg des Neukantianismus. Die deutsche Universitätsphilosophie zwischen Idealismus und Positivismus, Frankfurt am Main: Suhrkamp.

Laclau, E. (2005). On Populist Reason, London: Verso.

Lefort, C. (1988). Democracy and Political Theory, trans. D. Macey, Minneapolis: University of Minnesota Press.

Lilla, M. (1997). 'The Enemy of Liberalism,' The New York Review of Books, Vol. 44, No. 8, available on-line at http://www.nybooks.com/articles/archives/1997/ may/15/the-enemy-of-liberalism/?insrc=toc (accessed on April 5, 2020).

Löwith, K. (1984). 'Der okkasionelle Dezisionismus von C. Schmitt,' in K. Löwith, Heidegger - Denker in dürftiger Zeit, Stuttgart: J. B. Metzler, pp. 32-71.

Lukács, G. (1968). 'Rezension: Carl Schmitt, Politische Romantik,' in G. Lukács, Geschichte und Klassenbewußtsein, Neuwied: Luchterhand, pp. 695-696.

Magalhães, P. T. (2016). 'A Contingent Affinity: Max Weber, Carl Schmitt, and the Challenge of Modern Politics,' Journal of the History of Ideas, Vol. 77, No. 2, pp. 283-304.

Maier, C. S. (1988). Recasting Bourgeois Europe: Stabilization in France, Germany, and Italy in the Decade after World War I, 2nd ed., Princeton: Princeton University Press.

Mannheim, K. (1954). Ideology and Utopia, trans. L. Wirth and E. Shils, New York: Harcourt Brace.

Mateo, M. M. (2016). Politik der Repräsentation. Zwischen Formierung und Abbildung, Wiesbaden: Springer.

McCormick, J. P. (1998). 'The Dilemmas of Dictatorship: Carl Schmitt and Constitutional Emergency Powers,' in D. Dyzenhaus (ed.), Law as Politics: Carl Schmitt's Critique of Liberalism, Durham: Duke University Press, pp. 217-251.

Mehring, R. (2009). Carl Schmitt. Aufstieg und Fall, Munich: C. H. Beck.

Meier, H. (1988). Carl Schmitt \& Leo Strauss: The Hidden Dialogue, trans. J. H. Lomax, Chicago: University of Chicago Press.

Meier, H. (2004). Die Lehre Carl Schmitts. Vier Kapitel zur Unterscheidung Politischer Theologie und Politischer Philosophie, 2nd ed., Stuttgart: J. B. Metzler.

Missfelder, J.-F. (2006). 'Die Gegenkraft und ihre Geschichte: Carl Schmitt, Reinhart Koselleck und der Bürgerkrieg,' Zeitschrift für Religions- und Geistesgeschichte, Vol. 58, No. 4, pp. 310-336.

Mohler, A. (1989). Die Konservative Revolution in Deutschland 1918-1932. Ein Handbuch, 3rd ex. ed., Darmstadt: Wissenschaftliche Buchgesellschaft.

Mommsen, W. J. (1974). Max Weber und die deutsche Politik 1890-1920, 2nd ex. ed., Tübingen: Mohr Siebeck.

Motschenbacher, A. (2000). Katechon oder Großinquisitor? Eine Studie zu Inhalt und Struktur der Politischen Theologie Carl Schmitts, Marburg: Tectum.

Mouffe, C. (ed.) (1999). The Challenge of Carl Schmitt, London: Verso.

Mouffe, C. (2005). The Democratic Paradox, London: Verso.

Müller, J.-W. (1997). 'Carl Schmitt-An Occasional Nationalist?,' History of European Ideas, Vol. 23, No. 1, pp. 19-34. 
Müller, J.-W. (2016). What is Populism?, Philadelphia: University of Pennsylvania Press.

Palonen, K. (2002). Eine Lobrede für Politiker. Ein Kommentar zu Max Webers „Politik als Beruf," Wiesbaden: Springer.

Pranchère, J.-Y. (2001). 'Joseph de Maistre's Catholic Philosophy of Authority,' in R. A. Lebrun (ed.), Joseph de Maistre's Life, Thought, and Influence: Selected Studies, Montreal: McGill-Queen's University Press, pp. 131-150.

Rogers, M. D. (2016). 'The Development of Carl Schmitt's Political Thought during the First World War,' Modern Intellectual History, Vol. 13, No. 1, pp. 123-149.

Scheuerman, W. E. (2007). 'Carl Schmitt and Hans Morgenthau: Realism and beyond,' in M. C. Williams (ed.), Realism Reconsidered: The Legacy of Hans J. Morgenthau in International Relations, Oxford: Oxford University Press, pp. 62-92.

Schmidt, H.-J. (1999). 'The Papal and Imperial Concept of plenitudo potestatis: The Influence of Pope Innocent III on Emperor Frederick II,' in J. Moore (ed.), Pope Innocent III and his World, Aldershot: Ashgate, pp. 305-314.

Schmitt, C. (1912a). Gesetz und Urteil, Berlin: Otto Liebmann.

Schmitt, C. (1912b). 'Kritik der Zeit,' Die Rheinlande, Vol. 22, pp. 323-324.

Schmitt, C. (1914). Der Wert des Staates und die Bedeutung des Einzelnen, Tübingen: Mohr Siebeck.

Schmitt, C. (1916). Theodor Däublers „,Nordlicht.“ Drei Studien über die Elemente, den Geist und die Aktualität des Werkes, Munich: Georg Müller.

Schmitt, C. (1916/1917). 'Diktatur und Belagerungszustand. Eine staatsrechtliche Studie,' Zeitschrift für die gesamte Strafrechtswissenschaft, Vol. 38, pp. $138-161$.

Schmitt, C. (1917). 'Die Einwirkungen des Kriegszustandes auf das ordentliche strafprozessuale Verfahren,' Zeitschrift für die gesamte Strafrechtswissenschaft, Vol. 38, pp. 783-797.

Schmitt, C. (1917/1918). 'Die Sichtbarkeit der Kirche. Eine scholastische Erwägung,' Summa, Vol. 1, No. 2, pp. 71-78.

Schmitt, C. (1921). Die Diktatur. Von den Anfängen des modernen Souveränitätsgedankens bis zum proletarischen Klassenkampf, Munich: Duncker \& Humblot.

Schmitt, C. (1923). 'Soziologie des Souveränitätsbegriffes und politische Theologie,' in M. Palyi (ed.), Errinerungsgabe für Max Weber, Vol. 2, Munich: Duncker \& Humblot, pp. 3-35.

Schmitt, C. (1927). 'Der Begriff des Politischen,' Archiv für Sozialwissenschaft und Sozialpolitik, Vol. 58, pp. 1-33.

Schmitt, C. (1931). Der Hüter der Verfassung, Tübingen: Mohr Siebeck.

Schmitt, C. (1933). Der Begriff des Politischen, Hamburg: Hanseatische Verlagsanstalt.

Schmitt, C. (1935). Staat, Bewegung, Volk, Hamburg: Hanseatische Verlagsanstalt.

Schmitt, C. (1963). Der Begriff des Politischen. Text von 1932 mit einem Vorwort und drei Corollarien, Berlin: Duncker \& Humblot.

Schmitt, C. (1968). Legalität und Legitimität, 2nd ed., Berlin: Duncker \& Humblot.

Schmitt, C. (1970). Politische Theologie II. Die Legende von der Erledigung jeder Politischen Theologie, Berlin: Duncker \& Humblot. 
Schmitt, C. (1982). Der Leviathan in der Staatslehre des Thomas Hobbes. Sinn und Fehlschlag eines politischen Symbols, 2nd ed. (G. Maschke), Cologne: Hohenheim.

Schmitt, C. (1986). Political Romanticism, trans. G. Oakes, Cambridge, MA: MIT Press.

Schmitt, C. (1988). The Crisis of Parliamentary Democracy, trans. E. Kennedy, Cambridge, MA: MIT Press.

Schmitt, C. (1994). Positionen und Begriffe im Kampf mit Weimar - Genf Versailles, 1923-1939, 3rd ed., Berlin: Duncker \& Humblot.

Schmitt, C. (1998). 'Strong State and Sound Economy: An Address to Business Leaders,' in R. Cristi, Carl Schmitt and Authoritarian Liberalism, Cardiff: University of Wales Press, pp. 213-232.

Schmitt, C. (2005). Political Theology, trans. G. Schwab, Chicago: University of Chicago Press.

Schmitt, C. (2008). Römischer Katholizismus und politische Form, 5th ed., Stuttgart: Klett-Cotta.

Schmitt, C. (2009). Politische Theologie. Vier Kapitel zur Lehre von der Souveränität, 9th ed., Berlin: Duncker \& Humblot.

Schmitt, C. (2010). Verfassungslehre, 10th ed., Berlin: Duncker \& Humblot.

Schmitt, C. (2014). Dictatorship: From the Origin of the Modern Concept of Sovereignty to Proletarian Class Struggle, trans. M. Hoelzl and G. Ward, Cambridge: Polity.

Schmitt, C. (2015). Glossarium. Aufzeichnungen aus den Jahren 1947 bis 1958, 2nd ed., Berlin: Duncker \& Humblot.

Schmitt, C. (2019). 'The Buribunks. An Essay on the Philosophy of History,' trans. G. Reifarth and L. Petersen, Griffith Law Review, DOI: 10.1080/10383441.2019.1646199.

Schoonmaker, D. (1988). 'Schmitt Reconsidered,' The Review of Politics, Vol. 50, No. 1, pp. 130-132.

Schupmann, B. A. (2017). Carl Schmitt's State and Constitutional Theory: A Critical Analysis, Oxford: Oxford University Press.

Sieyès, E. J. (2002). Qu'est-ce que le Tiers état?, Paris: Éditions du Boucher.

Simmel, G. (1999). 'Der Konflikt der modernen Kultur,' in G. Simmel, Gesamtausgabe, Vol. 16, ed. G Fitzi and O. Rammstedt, Frankfurt am Main: Suhrkamp, pp. 181-207.

Stammer, O. (ed.) (1971). Max Weber and Sociology Today, New York: Harper \& Row.

Strauss, L. (1952). Persecution and the Art of Writing, Chicago: University of Chicago Press.

Strauss, L. (1988). 'Notes on Carl Schmitt, The Concept of the Political', in H. Meier, Carl Schmitt \& Leo Strauss: The Hidden Dialogue, trans. J. H. Lomax, Chicago: University of Chicago Press, pp. 91-119.

Stolleis, M. (2004). A History of Public Law in Germany: 1914-1945, trans. T. Dunlap, Oxford: Oxford University Press.

Suuronen, V. (2020). 'Carl Schmitt as a Theorist of the 1933 Nazi Revolution: "The Difficult Task of Rethinking and Recultivating Traditional Concepts,", Contemporary Political Theory, DOI: 10.1057/s41296-020-00417-1.

Tuori, K. (2016). 'Schmitt and the Sovereignty of Roman Dictators: From the Actualisation of the Past to the Recycling of Symbols,' History of European Ideas, Vol. 42, No. 1, pp. 95-106. 
Ulmen, G. L. (1991) Politischer Mehrwert. Eine Studie über Max Weber und Carl Schmitt, Weinheim: VCH.

Vatter, M. (2016). 'The Political Theology of Carl Schmitt,' in J. Meierhenrich and O. Simons (eds), The Oxford Handbook of Carl Schmitt, Oxford: Oxford University Press, pp. 245-268.

Villa, D. (2013). 'The Legacy of Max Weber in Weimar Political and Social Theory,' in P. E. Gordon and J. P. McCormick (eds), Weimar Thought: A Contested Legacy, Princeton: Princeton University Press, pp. 73-86.

Voegelin, E. (1936). Der autoritäre Staat. Ein Versuch über das österreichische Staatsproblem, Vienna: Springer.

Voegelin, E. (2001). 'Die Verfassungslehre von Carl Schmitt,' in E. Voegelin, Collected Works, Vol. 13 (Selected Book Reviews), ed. J. Cockerill and B. Cooper (eds), Columbia: University of Missouri Press, pp. 42-66.

Volkov, S. (2012). Walther Rathenau: Weimar's Fallen Statesman, New Haven: Yale University Press.

Vollrath, E. (1989). 'Wie ist Carl Schmitt an seinen Begriff des Politischen gekommen?', Zeitschrift für Politik, Vol. 36, pp. 151-168.

Wacker, B. (ed.) (1994). Die eigentlich katholische Verschärfung...Konfession, Theologie und Politik im Werk Carl Schmitts, Munich: Fink.

Weber, M. (1922). Wirtschaft und Gesellschaft, Tübingen: Mohr Siebeck.

Weber, M. (1978). Economy and Society, ed. G. Roth and C. Wittich, Berkeley: University of California Press.

Weber, M. (1994). Political Writings, ed. P. Lassman and R. Speirs, Cambridge: Cambridge University Press.

Weber, M. (2012). Collected Methodological Writings, ed. H. H. Bruun and S. Whimster, Abingdon: Routledge.

Weidermann, V. (2018). Dreamers: When the Writers Took Power, Germany, 1918, trans. R. Martin, London: Pushkin Press.

Windelband, W. (1916). Geschichtsphilosophie. Eine Kriegsvorlesung, Berlin: Reuther \& Reichard. 


\section{Science, Relativism and Pluralism}

\section{Hans Kelsen's Conception of Modern Democracy}

The study of Hans Kelsen's political thought puts the student of politics in a tight corner. The reason for this is not very hard to fathom. On the one hand, the scholar of politics, from the outset, must acknowledge that she or he is dealing with a thinker for whom political philosophy was only a secondary concern. Kelsen was above all a jurist, arguably the jurist of the twentieth century (Topitsch, 1982: 11), and his chief intellectual enterprise, across ca. 400 published works of uncompromisingly solid scholarship, was to vindicate the autonomy of law as a scientific discipline. His political thought, which constitutes in essence a theory and a defence of parliamentary democracy, can thus only be understood in light of that main scientific project - as the author himself did not fail to suggest from time to time. This requires all those who approach Kelsen's political thought from a non-juristic background to familiarize themselves with the fundamentals of a legal-theoretical edifice painstakingly developed and revised during the course of more than half a century, from the Hauptprobleme der Staatsrechtslehre (1911) to the posthumously published General Theory of Norms (1979). If to get a systematic grasp of such edifice is a daunting task for trained legal theorists, and controversies abound among the latter concerning its philosophical foundations and modulations across the years (Paulson, 1998), the political theorist cannot help but admit that $\mathrm{s} / \mathrm{he}$ is poorly equipped to plunge into its intricacies. And yet, he must dare enter a terrain which is not his own. On the other hand, however, the student of politics is perhaps in a fortunate position not to reduce Kelsen's political thought entirely to his legal science, a move which some of the most astute critics of the Austrian scholar have undertaken with considerable argumentative success. ${ }^{1}$ Thus, in this chapter, without neglecting its connection with Kelsen's grander intellectual project, we seek to assess the relevance and the limits of his pluralistic theory of modern democracy on its own terms. We will do so by discussing its similarities and contrasts to the intellectual and political orientations of Max Weber and Carl Schmitt, which we have examined in the previous chapters.

The chapter is divided into three parts. First, it outlines Kelsen's main scientific venture towards a so-called pure theory of law (reine

DOI: $10.4324 / 9781315157566-3$ 
Rechtslehre), elucidating its philosophical presuppositions and fundamental demarcations-from the empirical social sciences, on the one hand, and from an ideologically and metaphysically determined understanding of law and legal science, on the other hand. Second, the chapter considers Kelsen's case for parliamentary, party-pluralist democracy, as argued in the two versions of Vom Wesen und Wert der Demokratie, published in 1920 and 1929, as well as in other writings from the 1920s and early 1930s. I claim that, while this theory of democracy cannot be understood in isolation from Kelsen's central legal-theoretical endeavour, it also remains irreducible to the latter, for it touches upon crucial politicalphilosophical questions and involves a perhaps surprising sociological acumen for a self-professedly "pure" theorist of law. Finally, the third section contains a reflection on Kelsen's broader worldview, the tensions inhabiting it and the extent to which it constitutes the link between his legal science and his democratic thought. My contention is that the author espouses a circumspect, and yet resilient, scientistic worldview that accounts for both the strengths and the limits of his democratic theory. We conclude by suggesting the notion of indeterminacy, rather than Kelsen's somewhat misleading concept of relativism, as a fruitful alternative to think about democratic pluralism beyond Kelsen.

\section{The Pure Theory of Law and Its Adversaries: Towards a Legal Science beyond Empirical Fact and Absolute Value?}

\section{The Last Neo-Kantian}

In the previous chapters, we have considered the extent to which both Max Weber and Carl Schmitt were influenced by neo-Kantian philosophy in their basic intellectual orientation. In a certain sense, such an influence was inescapable for every scholar working in the broad domain of the human sciences, whose formative years elapsed in the Wilhelmine Empire, where neo-Kantianism constituted the dominant philosophical school in most German-speaking universities. Nevertheless, we concluded that the neo-Kantian influence, though not negligible, was far from being decisive to grasp the key aspects of their political thought. Weber spent most of his life in Heidelberg, a major hub of neo-Kantian philosophy, and he was personally acquainted with most of the leading neo-Kantian philosophers there. However, even if one concedes that Weber's weighty methodological writings cannot be abstracted from the contemporary debates in neo-Kantian epistemology, and especially from Heinrich Rickert's transcendental grounding for the human sciences (Oakes, 1988; Bruun, 2007), it would be a sign of short-sightedness, given the wide range of other philosophical influences, to narrow Weber down to a neo-Kantian sociologist. For Schmitt, in turn, who also graduated from a university - Strasbourg where prominent neo-Kantians taught, that philosophical current was one 
among other early influences. Yet, as we have shown, he departed from neo-Kantianism for good already during the First World War-to become, indeed, one of the fiercest critics of neo-Kantian legal theory. In fact, in the interwar years, the latter was principally championed by Hans Kelsen, who in a 1927 autobiographical letter to a Hungarian colleague was unambiguous concerning his chief philosophical influence:

Purity of method, indispensable to legal science, did not seem to me to be guaranteed by any philosopher as sharply as by Kant with his contrast between Is and Ought. Thus for me, Kantian philosophy was from the very outset the light that guided me. (Kelsen, 'Selbstdarstellung,' apud Baume, 2012: 5) ${ }^{2}$

It is interesting to note how the centre of neo-Kantian theory drifted from Germany to Austria, from Heidelberg and Marburg to Vienna, and from philosophy to jurisprudence, in the aftermath of the First World War. In Germany, as pointed out in the previous chapters, neo-Kantianism paid the price of having obediently engaged in the nationalist war propaganda of the Kaiserreich. Ineradicably linked to the "ideas of 1914," whose triad "duty-order-justice" 3 was coined in opposition to the French revolutionary "liberty-equality-fraternity," it was incapable of regaining the favour of the younger generations, who had lost their brothers and friends at the front. As Beiser (2013: 115) observes, even if neo-Kantianism in Germany died only in 1933, it was already 'in drastic decline' and 'fighting rearguard actions' since the end of the First World War. The famous showdown at Davos between Ernst Cassirer-one of the few neo-Kantians who had refrained from indulging in nationalistic war philosophy and could thus show untainted liberal-democratic credentials-and Martin Heidegger announced the fate of neo-Kantianism, with most of the youth present at the conference siding with Heidegger (Gordon, 2010). In Austria, however, neo-Kantian theory enjoyed a perhaps surprising boost after the Great War by the hand of a jurist, Hans Kelsen, who took it as the basis upon which to develop the epistemology and methodology of an autonomous legal science. Far from being a defensive, rear-guard fight, Kelsen's aspiration was to lead a veritable Copernican revolution in jurisprudence with the help of neo-Kantian theory. His aim was to determine what is specifically juristic in the realm of law and, subsequently, purge the science of law from all non-juristic elements misleadingly grafted upon it. To do so, the transcendental method as developed by neo-Kantian philosophy appeared to provide the most solid logical foundations. Furthermore, Kelsen was not alone in this enterprise, as rapidly a growing number of scholars gathered around him, forming what became known as the Vienna school of legal theory. ${ }^{4}$

This southward drift of neo-Kantian thought in the German-speaking space can be explained by relatively straightforward cultural reasons. 
Because it had not acquired a quasi-official status in the Habsburg Empire, neo-Kantianism in Austria, in contrast to Germany, could emerge less problematically as the philosophical orientation behind both a new theory of law and the constitutional order of a new republican, parliamentary-democratic regime. Kelsen, indeed, was charged with drafting the Austrian constitution of 1920 and later nominated on an unlimited tenure to the newly created constitutional court. To say, however, that the general cultural and political environment in Austria was comparatively more hospitable to a jurisprudence and politics informed by neo-Kantian theory does not mean that it was entirely hospitable. Not very differently from Weimar, the Austrian republic and its constitution were challenged, from the very outset, by the conservative-authoritarian right and the revolutionary left, and the catalogue of opponents grew by the end of the decade with the emergence of the Nazi movement.

However, the travelling of neo-Kantian theory to post-First World War Viennese jurisprudence generates an interesting intellectual puzzle of its own. For Kelsen, unlike Weber and Schmitt, was not trained in an academic environment with strong neo-Kantian influences, but rather came to adopt the neo-Kantian framework only after he had already developed a positivist legal theory based on different, arguably less sophisticated premises, in his bulky post-doctoral thesis from 1911, Hauptprobleme der Staatsrechtslehre. In his periodization of Kelsen's legal theory, Heidemann (1997: 19) calls this first phase, marked by the Hauptprobleme and extended until roughly 1915, "constructivist," in the sense that Kelsen aimed to construct the concepts of legal science from the positive normative material alone. To be sure, the basic Kantian distinction between Is (Sein) and Ought (Sollen) was there to begin with. Sustained by references to the neo-Kantian philosopher Windelband as well as to renowned scholars who had absorbed neo-Kantian epistemological insights both in the natural (Helmholtz) and in the social (Simmel) sciences, Kelsen (1923a: 4-5) draws a sharp contrast between the causal-explanatory and the normative concepts of law (Gesetz). 'The contrast between Is and Ought,' he argued, 'is a formal-logical one, and as long as one remains within the limits of formal-logical observation, no way leads from one to the other, the two worlds stand opposite each other, separated by an unbridgeable gap' (Kelsen, 1923a: 8). ${ }^{5}$ However, beyond such preliminary remarks, the author remained in essence within the late nineteenth-century imperial tradition of statutory positivism. Having studied with the leading names of the legal positivist establishment in Vienna (Bernatzik and Menzel), as well as in Berlin (Anschütz) and Heidelberg (Jellinek), Kelsen's early work can be described as an attempt to elevate such a tradition from the level of descriptive normative analysis to that of systematic, abstractformal conceptualization, solving some of its aporias - such as Jellinek's dualistic doctrine of the state - along the way. Kelsen replaces the statute (Gesetz) as the fundamental unit of legal cognition by the Rechtssatz, 
which the translators of the first edition of Reine Rechtslehre (1934) render in English as the 'reconstructed legal norm. ${ }^{6}$ The latter, of course, must be assembled from the content of positive statutes, but it is situated at a higher plane of abstraction, representing the ideal logical form of the legal norm. ${ }^{7}$

The "constructivist" phasein Kelsen's theory is followed by a transitional period, elapsing from 1916 to 1922, where the author moves ever closer to a transcendental grounding for legal theory (Heidemann, 1997: 43). The subsequent, transcendental phase runs across the 1920s and climaxes in the publication of the first edition of Reine Rechtslehre. In this phase, the Kantian or rather neo-Kantian undergirding of Kelsen's main theses takes centre stage. This is clearly noticeable in the long preface to the second edition of the Hauptprobleme, where Kelsen projects a distinctly neo-Kantian epistemological framework retrospectively upon his earlier, "constructivist" work. There, he argues that the 'reconstructed legal norm' should be understood as a hypothetical judgement, not as a subjective imperative; draws a parallel between his distinction of legal and psychological will and Husserl's general contrast between logicism and psychologism, as developed in the Logical Investigations (1900-1901) ${ }^{8}$; substitutes a dynamic for a static conception of the legal system, the former requiring the concept of a Basic Norm (Grundnorm) as the hypothetical foundation of juristic cognition that cannot itself be derived from the positive normative material and, perhaps most importantly, refers to Hermann Cohen's Kant interpretation in Ethik des reinen Willens (1904) as providing him the epistemological insight with which to arrive at the notion that, from the perspective of juristic cognition, the concepts of state and law are perfectly synonymous, and not two different sides of the same coin (Kelsen, 1923a: vii, ix, xiv-xv, xvii). The retrospective projection of the transcendental framework upon the "constructivist" phase, in any case, results mostly in a refinement, rather than in a massive revision, of the earlier arguments, where key notions-such as the concept of imputation (Zurechnung) as the normative equivalent to the naturalscientific principle of causality — had already reached a remarkable level of elaboration. Hence, it seems fair to conclude that the "constructivist" Kelsen was a neo-Kantian by intuition, whereas later on his employment and refinement of the transcendental method became self-conscious.

The precise nature and concrete sources of Kelsen's Kantian or neoKantian argument is a matter of dispute in the secondary literature. The case for a Kantian argument has been developed by Ebenstein (1969). In my view, however, it is a weak case, for it rests on the analogy between, on the one hand, the argumentative strategies employed by Kant (1998: 470-477) in the Critique of Pure Reason to overcome the so-called mathematical antinomies that plagued the thought of Continental rationalists and British empiricists and, on the other hand, Kelsen's attempt to cut through the impasses of what Paulson (1992: 313) terms 


\section{Science, Relativism and Pluralism}

'the jurisprudential antinomy' of traditional positivist and natural law theory. Granted, the similarities between both approaches are striking, but they remain at the surface level of discourse analysis. That is, Kelsen might very well employ a Kantian rhetorical strategy, but his transcendental legal-theoretical argument is distinctly neo-Kantian. First, because it takes the transcendental method as developed in Kant's theoretical philosophy for the crowning achievement of Kantian thought tout court, extending it to other fields, including those of practical philosophy, where Kant-unfortunately and contradictorily, according to the neo-Kantians - had still succumbed to metaphysics. ${ }^{9}$ Second, because Kelsen's theory adheres to a characteristically neo-Kantian, regressive version of the transcendental argument, which proceeds "backwards," as Paulson (1992: 330) puts it, "from experience that is already cognized, from the Faktum of science'-i.e. from the notion that one has knowledge of legal norms - 'to the presupposed category or principle' (in Kelsen's legal theory, the principle of imputation), rather than "forward" from the sense-data given prior to all intellectual synthesis, through the category constituting the condition of possibility of knowledge (e.g. causality), to the actual statement of cognition.

As regards the question of which variety of neo-Kantian theory Kelsen draws predominantly upon, there is no doubt that, in contrast to Weber and Schmitt, the Marburg school's penchant for logification exerted a much stronger influence on his work than the orientation of the Heidelberg school, especially with Rickert and Lask, towards the problems of singularity, value and meaning in the so-called cultural sciences. In 1916, Kelsen published a demolishing critique of Rickert's method of value-relatedness (wertbeziehende Methode) as a means of establishing a distinction between the natural and the cultural sciences on firm logical grounds. ${ }^{10}$ Kelsen's fundamental point is that Rickert collapses the irreconcilable antagonism of Is and Ought, which alone can provide the sound methodological foundation for a division within the realm of knowledge. Ultimately, sciences diverge in two directions and two directions only: those which, through their concepts and methods, pursue the cognition of reality or facts and those whose conceptual framework aims for the cognition of ideality or norms (Kelsen, 1968a: 37-38). If one takes the concept in its, according to Kelsen (1968a: 40), broad Kantian sense, nature turns out to be identical with reality, and therefore it becomes highly problematic to establish a contrast within reality between nature and culture. Rickert tries to do so by submitting that culture implies a relation to value (Wertbezogenheit), which elevates it above nature. For Kelsen, this amounts to an inadmissible blurring of the lines separating facts and norms, empirical and normative disciplines:

Reality and ideality can never be combined in a concept or grasped from the standpoint of the same science, for reality only arises from 
a point of view that is significantly different from that of ideality. A scientific content exists only either through the specific form of cognition of the Is or through that of the Ought. In the first case, it exists as reality, in the second as value. Through utterly different directions of knowledge, that which is given becomes reality or value.

(Kelsen, 1968a: 46) ${ }^{11}$

By failing to live up to this strict either/or, Rickert fell prey to methodological syncretism. His method of value-relatedness, which was supposed to constitute the concept of culture in sharp contrast to that of nature, vacillates between pretensions to objective value-cognition, which it cannot fulfil as long as it remains directed at reality, and the mere description of the pursuit of subjective values by real historical agents (Kelsen, 1968a: 60 ). The philosophical mooring of law as a strictly normative discipline, on the contrary, would have to come from a theory which adheres rigorously to the methodological dualism of Sein and Sollen, as well as to the transcendental principle which states that concepts and methods generate the object of knowledge, without giving an inch to the notion that certain objects might possess some intrinsic, singular meaning or relate in and by themselves to the sphere of value and normativity. Kelsen found this theory in the neo-Kantian philosophy of the Marburg school. ${ }^{12}$

\section{The Anti-Empirical Thrust of Kelsen's Theory}

In the decade after the publication of the Hauptprobleme, Kelsen invests a substantial portion of his intellectual energy in the effort to assert the autonomy of legal science over against the neighbouring disciplines of sociology and the Rickertian cultural sciences. The chief output of this effort is arguably the 1922 monograph on the distinction between the sociological and the juristic conceptions of the state (Kelsen, 1981). The guiding principle of the legal theorist's argument is condensed in the statement, formulated in a 1911 piece where he sums up the results of his post-doctoral thesis, that '[t]he methodological contrast between sociology and jurisprudence... is that between Is and Ought' (Kelsen, 1968b: 5-6). ${ }^{13}$ Against what he saw as the excessive ambitions of legal sociologists, such as Eugen Ehrlich and Hermann Kantorowicz, ${ }^{14}$ as well as against the attempts, inspired by Rickert, to conceive legal science as a cultural discipline, Kelsen would invariably maintain that these boiled down to different varieties of methodological syncretism, to different versions of the same logical mistake, which consisted in confounding the cognition of empirical realities with that of normative idealities. The opposed, logically consistent position would be to distinguish judiciously between, on the one hand, sociology and the historical cultural sciences, as disciplines dealing with empirical facts linked to each other as causes and effects, and, on the other hand, dogmatic jurisprudence 
as a discipline that relates concrete normative contents to more general ones. In the lines that follow, we will elucidate the anti-empirical thrust of Kelsen's legal theory by examining his critique of the Heidelbergbased, neo-Kantian project of adding jurisprudence to the domain of the cultural sciences. This will allow us to pinpoint some key differences between, on the one hand, Kelsenian legal theory and, on the other hand, Carl Schmitt's early thought and especially Max Weber's sociology, which as we have seen were both - though the latter certainly more than the former-influenced by Southwest German neo-Kantianism.

In the above-quoted article on jurisprudence as a normative or as a cultural science, Kelsen extends his critique of Rickert, who had only made brief allusion to the possibility of treating law as an empirical cultural discipline, to the latter's followers - namely, the philosopher Emil Lask and the jurist Gustav Radbruch - who sought to think that possibility through. In his Rechtsphilosophie (1907), Lask takes the fundamental dualism of Ought and Is, value and reality, as his point of departure to oppose legal philosophy, as a theory of the value of law, to legal science as the discipline which considers law in its reality. This student of Rickert then conceives the relation between both in such a way that legal reality is taken to be the setting or the substrate of the supra-empirical values which legal philosophy studies. Reality is, thus, conceived by Lask as an entity upon which values cling, and this adherence of value is indeed what sets the domain of culture, which includes the law, apart from nature. This, however, constitutes a major logical confusion from the standpoint of transcendental epistemology, for what is understood by "legal" in Lask's distinction between philosophy and science cannot be the same thing. The two disciplines simply do not share an identical object, which would justify the transition, in one breath, from one's perspective to the other. 'For philosophy cannot consider "reality" from the point of view of its absolute value content,' says Kelsen (1968a: 66), 'if reality itself is only the result of an absolutely value-free consideration. ${ }^{, 15}$ Lask's logical misunderstanding and the resulting methodological syncretism proceed, according to Kelsen (1968a: 73-74), from an erroneous conception of legal positivism. Contrary to what Lask thought - and here he was following the dominant juristic opinion - the positivity of law does not reside in its de facto existence, in the empirical effectiveness of the legal order. Rather, the positivity of the legal order, understood as a self-contained system of norms, designates the circumstance that it constitutes an ultimate, no further derivable normative system. The validity of the legal order rests upon its specific normative content, not upon an empirical fact; its positive nature, in turn, should hence be understood in a purely formal sense. Kelsen's verdict on Lask, who as a trained logician should not have taken the prevailing juristic opinion at face value, could thus scarcely be more crushing:

It is not too strange that juristic theory, concerning the problem of the positivity of law, made the grave mistake of tracing the validity 
of the legal order, i. e. the legal Ought, back to a tangible fact, to a real process. After all, legal theory developed quite apart from philosophical speculations, in particular those of methodological and epistemological nature, and has so far hardly been touched by the methodological dualism of transcendental critical philosophy. It is less understandable that a philosopher, and especially one who acts as a representative of critical methodological dualism and as such would be in a privileged position to free jurisprudence from some confusion, reinforces the latter in one of its most disastrous errors. Indeed, it is even more deplorable that a philosopher opposes the few, but gratifying, steps already taken by jurisprudence in a critical methodological direction with the full weight of his philosophical authority.

(Kelsen, 1968a: 75-76) ${ }^{16}$

According to Kelsen, however, the contradictions of the Heidelbergian cultural scientific approach to law emerge even more clearly in the work of a jurist who sought to square the circle and treat legal science simultaneously as an empirical and as a normative discipline. In his Grundzüge der Rechtsphilosophie (1914), Gustav Radbruch claims that while legal science, according to its object, constitutes an empirical discipline, it is nevertheless a normative science according to its method. Radbruch reaches this conclusion by autonomizing Rickert's concept of culture, which the philosopher had still included within the sphere of Sein, conferring it the status of an intermediate realm between fact and value. The law, as a cultural phenomenon, then falls within such an intermediate realm. The notion of a third, hybrid realm between reality and ideality is, of course, irreconcilable with a strict methodological dualism. Here, notwithstanding the major ideological differences between the future social-democratic minister of justice in Weimar and the authoritarianism of Carl Schmitt, there are striking similarities between Radbruch's legal-philosophical reflections and Schmitt's contemporary observations on the value of the state, which we surveyed in the previous chapter. To be sure, for Schmitt, it was the state rather than the law that stood in between the "two worlds" of facts and norms. In that sense, he pierced through the neo-Kantian dualism by way of a Hegelian synthesis tinged with Roman Catholic institutional formalism, envisioning the state as a sort of concrete universal, as law made flesh. Radbruch, in turn, operating closer to the neo-Kantian premises of the Heidelberg philosophers, conceived the intermediate realm of culture, to which the law belonged, as internally divided in empirical and normative dimensions. The latter justified treating dogmatic jurisprudence as a purely normative endeavour - something of the utmost importance for professional jurists, lest they become replaceable by sociologists - whereas the former nevertheless permitted an empirical treatment of the law. More specifically, Radbruch posited that dogmatic jurisprudence was strictly concerned 
with the meaning (Sinn) of law, while legal science as an empirical cultural discipline dealt with its actuality. For Kelsen, every attempt to bridge the rift separating Sein and Sollen, to soften the strict dichotomy through whichever third way, was doomed from the outset and should be dismissed as a logical impossibility. Against Schmitt's early conception of the state as a synthesis of norm and fact, Kelsen would have maintained that the state must either be conceived, sociologically, as a power apparatus or, juristically, as a self-contained normative system. To Radbruch's distinction between the empirical object of legal science and its normative method, Kelsen replies that object and method are inseparably conjoined, that an empirical object can only be gained through empirical methods and, mutatis mutandis, normative methods generate their own normative objects. ${ }^{17}$

Now, Max Weber was personally acquainted with Rickert, Lask and Radbruch, who were all regulars in Weber's Sunday afternoon intellectual salon, hosted in his large villa by the river Neckar. From this shared milieu, intellectual affinities naturally emerged, and the relevance of Rickert's philosophy for the development of Max Weber's methodology has been extensively dissected by the Weberian critical literature (Oakes, 1988; Bruun, 2007; Wagner and Härpfer, 2015a). Thus, one could have deemed it possible for Kelsen to extend his biting critique of Heidelberg neo-Kantianism to Weber. This, however, does not occur, and the references to Weber one encounters in Kelsen's writings are generally positive and always courteous. There are, on the face of it, perhaps two main reasons for this. The first and more prosaic one is that Weber never intended to restlessly sociologize or historicize legal science. The German thinker, who got both his doctoral and post-doctoral degrees from a law faculty, was content to leave dogmatic jurisprudence be a normative discipline, even if he endeavoured to explain the rise of rationalized legal dogmatics from the perspective of empirical social science. In that sense, in contrast to Lask and Radbruch, Weber constituted no immediate threat to Kelsen's legal-theoretical project. The second, equally plausible reason is that Weber's reception of Rickert was rather more nuanced and ambivalent than Lask's and Radbruch's. 'Weber's methodological reflections,' as Dewalque (2016: 80) puts it, 'appear as a mixture of Rickertian and non-Rickertian theorems.' In particular, Weber rejected any system of ultimate values, a position which drew him closer to Kelsen's axiological relativism. Moreover, as Wagner and Härpfer (2015b) point out, Weber's social scientific methodology developed in close dialogue with, rather than in contrast to, the natural sciences ${ }^{18}$ which from a Kelsenian perspective could be interpreted as a welcome reclosure of the split between culture and nature, which Rickert had unduly introduced in the logically unitary realm of the empirical, causal-explanatory sciences. Nonetheless, what seems to me to be the case is that Kelsen interprets Weber too one-sidedly in light of his own thinking, thus overlooking key differences 
between the underlying assumptions of Weber's social scientific project and the strict transcendental-constructivist logicism undergirding his legal-theoretical enterprise. What Kelsen, more than just suggesting, actually submits is that Weber came very close to saying exactly what he, Kelsen, thought about law and state, and would indeed have said it, if he had not been diverted by some minor misunderstandings.

In 1921, Kelsen published an article on the concept of the state in interpretive sociology that constitutes, in essence, a review of Weber's 'Basic Sociological Terms,' the conceptual introduction to Economy and Society. Kelsen (1921: 104) considers Weber's work 'the most important sociological achievement' since Simmel's Sociology (1908). Yet, he quickly hastens to add that this great achievement, too, merely

confirms that all efforts to determine the nature of the state through an extra-juristic, and especially sociological, path come down to a more or less concealed identification of the concept one is looking for with the concept of the legal order

(ibid.). ${ }^{19}$

In the case of Weber's sociology, Kelsen argues, this unavoidable result is in fact predetermined by the peculiarity of its interpretive method (verstehende Methode). Weber (2012: 114), in his agenda-setting article for the Archiv für Sozialwissenschaft und Sozialpolitik from 1904, might very well have described his social scientific endeavour as 'a science of reality, ${ }^{20}$ and sought to contrast it in every other occasion from formal-legal dogmatic cognition, but as long as he insisted that its aim was to discern and interpret meaning (Sinn), he would, according to Kelsen, have to concede that it was only secondarily concerned with the causal explanation of empirical phenomena. For meaning is not a property of real facts, but rather of idealities, of purely intellectual contents. Hence, insofar as it wished to remain "interpretive," sociology would have to acknowledge its derivative status as a discipline, i.e. its reliance on other normative sciences that would furnish sociology the principles according to which the meaning of phenomena should be interpreted (Kelsen, 1921: 105). As the Austrian jurist sees it, what Weber terms ideal or pure types are precisely these principles of interpretation, which are exogenous to sociology as an empirical science. When it comes to the problem of the state, the question is thus from which normative perspective should sociology draw to understand its meaning, since "the state," like any other collective social entity, and as Weber himself admits, has no real substance of its own (Kelsen, 1921: 107). The answer, of course, is normative legal science as Kelsen conceives it:

From the critical analysis of the relevant basic terms of "interpretive sociology" carried out here, it emerges that Weber did not need to 
limit himself - thus cautiously leaving the question of the relationship between state and law open - to saying that the possession of an administrative and legal system is a key characteristic of the state. Rather, the whole structure of Weber's conceptual system pushes us to realize that the state is a legal order. The sociology of the state is thus exposed as a theory of law. The constant reference to facticity... cannot change that. The primary, truly fundamental significance of the normative concept of law is inextricably captured in the method of "interpretive" sociology. For the latter is directed at the meaning of action, and this meaning, where the investigation targets the state, always turns out to be the idea of law as a compulsory norm. Interpretive sociology must sink into this immanent meaning, it must adopt the specific viewpoint of juristic observation, if it is to be able to interpret actions. Everything that this sociology can say about the nature of the state lies already resolved within this immanent, specifically juristic meaning; it adds not a single tiny word more to what the normative theory of law teaches.

(Kelsen, 1921: 117-118) $)^{21}$

Therefore, to be able to grasp the meaning of the state, which is a purely intellectual construct, Weber would have to look through the eyes of a pure theory of law, i.e. to put it bluntly, through Kelsen's own eyes. And indeed, according to the Austrian jurist, he came ever so close to doing so, were it not for excessive cautiousness, an unessential insistence on the empirical orientation of his scholarly endeavour and a regrettable reliance on outdated, "substantivistic" conceptions of law and state (such as Jellinek's). This skewed reading of Weber's sociology, which at times borders on the patronizing, is only possible to the extent that Kelsen restricts his critical enquiry to the conceptual apparatus of Weberian sociology, as outlined in the 'Basic Sociological Terms,' thus avoiding to take stock of the actual sociological research conducted by Weber on domination, religion and law. Such an approach, to be sure, is justified by the self-referential logicism of Kelsen's Marburg neo-Kantian epistemology, according to which concepts and methods fully constitute the object of any given science. Even so, Kelsen's logical insight misses fundamental aspects of Weber's conceptualization. The notion of legitimacy is a case in point. Kelsen (1921: 116-117) assumes that Weber's concepts of legitimacy and validity are wholly exhausted by the systematic unity of formalrational, impersonal legality characteristic of - or, rather, which is one with - the modern state; and, more than that, he claims Weber himself, even if unwittingly, shared this assumption. However, as noted in our chapter on Weber, the German scholar was not targeting legitimacy and validity per se as his subject matter, but rather 'the belief in the existence of a legitimate order' (Weber, 1978: 31). ${ }^{22}$ Of course, had Kelsen realized that this was the main aim of Weber's sociology of domination - which, 
incidentally, is not synonymous with a sociology of the state-he could have again raised the classical charge of methodological syncretism, and accused Weber of conflating the normative categories of validity and legitimacy with the empirical category of belief, understood as a subjective, psychologically explainable devotion to symbols and ideals. What he could not have done, however, was to read Weber as if he was trying to say what Kelsen had already said concerning the nature of the state.

Furthermore, Kelsen's (1921: 105-106) understanding of the Weberian methodology of the ideal type is also indelibly marked by his adherence to a rather extreme variety of normative logicism. Granted, Weber's ideal type is most accurately perceived as a conceptual construction, as a logical type rather than as a purely descriptive, statistically inferable, average type or as a prescriptive, ideologically charged one. In Weber's (2012: 134-135) view, too, empirical reality can only be mastered by conceptual-theoretical means, as Kant had taught. However, reality cannot be wholly mastered, much less entirely constructed, by such means. 'For Weber,' as Schluchter (1981: 14) keenly puts it, 'the hiatus irrationalis between concept and subject matter cannot be resolved.' Thus, notwithstanding the rejection of "objective" reality as empirically given, and the acknowledgement of the logical priority of concept formation in social scientific enquiry, Weber does not conceive the relation between concepts and methods, on the one hand, and the object of knowledge, on the other hand, in terms of a unilateral constitution of the latter by the former. There is, in other words, a feedback loop, with the object of social scientific cognition constantly reshaping, refining and differentiating the very same conceptual tools which constitute it, in an interactive process that will never attain full closure. It is this open-ended process of refinement and differentiation, rather than any fundamental differences concerning the nature of scientific explanation, that accounts for the diversity among the "sciences of reality," and which the difficult notion of the Weberian ideal type, as I interpret it, seeks to capture. Without such interaction, and to the extent that the basic a priori concepts of space, time and causality are shared by all empirical disciplines, a universal "science of reality" would emerge as a logical necessity. Kelsen, indeed, recognized and welcomed such a necessity. For him, the empirical sciences were ultimately as self-positing and self-referential as the normative disciplines. ${ }^{23}$ Weber's ideal-typical concepts, in contrast, remained open to a reality beyond the conceptual apparatus, even if Weber conceded that such reality could never be comprehensively grasped.

Our emphasis on such fundamental differences, which Kelsen's reading of Weber failed to discern, does not intend to obscure some significant similarities between both authors' approaches. Not even the most benevolent reader of Kelsen's sociological studies would, I suspect, claim that they come close to the historical richness and analytical insight of Weber's sociology. ${ }^{24}$ Still, it is safe to maintain that they were equally 
critical of the tendency in the empirical social sciences to reify collective entities. In this regard, one can assert that they both plead for a seemingly paradoxical "sociology without society." 25 To what extent this pushed them in the direction of methodological individualism is a controversial issue. I would say that Kelsen comes closer to such a position than Weber, especially considering his praise of Freudian psychology as the quintessential empirical human science (Kelsen, 1968d). Even if Weber (1978: 13), in principle, saw 'individual persons' as the only real carriers of action oriented towards meaning, treating 'social collectivities... as if they were individual persons' was, in practice, 'indispensable. ${ }^{26}$ What is more, patterns of interaction between individual agents tend to crystallize and thus acquire relative autonomy, which justified remaining - and Weber's sociological writings mostly do remain - at a supra-individual level of analysis. Be that as it may, in conclusion, one must reiterate that the stark anti-empirical thrust of Kelsen's legal theory, to cite a thoughtful Kelsen scholar, made him 'incapable of grasping the complexity of Weber's enterprise - which he intolerably simplifies' (Carrino, 1995: 201). To this, I would only add that Weber's failure to solve the methodological problem of inferring meaning from, or imputing meaning to, reality is endlessly more stimulating and fruitful than the empty methodological success of a theory closed in on its strictly defined concepts. There is more to verstehen than begreifen. ${ }^{27}$

\section{The Anti-Metaphysical Thrust of Kelsen's Theory}

The empirical social sciences, and in particular sociology, were by no means the only foes of Kelsen's pure theory of law. At the end of the day, they were arguably not even the main adversary. In the preface to the Introduction to the Problems of Legal Theory, the work that marks the zenith of his transcendental neo-Kantian phase, the author suggests this very clearly. Writing, in May 1934, from the safe haven of Geneva, where he had escaped from political persecution, the author states:

Contrary to appearances, the dispute is not in fact about the position of jurisprudence within science, and the consequences of that position. Rather, the dispute is about the relation between legal science and politics, the clean break between them; it is about giving up the deeply rooted custom of making political demands in the name of legal science - the custom, that is, of appealing to an objective authority in representing political demands, which can only be highly subjective, even if they purport in all good faith to be absolute values of a religion, a nation, or a class.

(Kelsen, 1992: 2)

Kelsen's attempt to purge legal science from political ideology was, thus, perceived by the author as a fight against the colonization of science 
by metaphysical, absolute values, which, given their subjective nature, were wholly unamenable to scientific consideration. This prompted him to a critique of key concepts in state theory, which he viewed as attempts to disguise political terms, and the ideological programmes they carried with themselves, as scientific ones. The concepts of legitimacy and, in particular, sovereignty are a case in point. At a very basic level, to Kelsen - and in this regard he does not differ substantially from Weber-legitimacy is about (self-)justification. Yet, contrary to Weber, the Austrian scholar disqualifies the problem of legitimacy altogether as a possible object of scientific enquiry. He excludes it not just from the science of law whose autonomy he endeavoured to assert, but from the domain of knowledge tout court. The charge against the 'ideology of legitimacy' in the 1934 Introduction reads as follows:

When the Pure Theory of Law rejects a legitimization of the state by way of the law, it does so not because, say, it declares every legitimization of the state to be impossible. The Pure Theory denies only that legal science has the capacity to justify the state by way of the law, or, what comes to the same thing, to justify the law by way of the state. The Pure Theory denies in particular that it can be the task of legal science to justify anything whatever. Justification means evaluation, which is always subjective and therefore a matter of ethics and politics, not of objective cognition. It is objective cognition alone that legal science, too, must serve, if it aims to be a science and not politics.

(Kelsen, 1992: 106)

In Kelsen's view, the concept of legitimacy throws us inescapably back to fierce ideological disputes that cannot be settled by the means of science. In a sense, one can argue that Kelsen was much more wary of the heavy politico-ideological burden carried by a concept that was forged in the doctrinal and political struggles of the French Revolution, ${ }^{28}$ whereas Weber dared to propose an empirically operative understanding of legitimacy against the accumulated conceptual-historical baggage of the term. Invocations of legitimacy, Kelsen (1992: 17-18, 37) argues, are always ideological: Their tendency is generally conservative, but they can also, and sometimes do have - as in the case of certain varieties of natural law theory - a transformative or even revolutionary drive to them. What they are not, even if they often try to pass as such, is postulates of knowledge.

Kelsen applies the same line of reasoning to the concept of sovereignty, to which, however, he devoted significantly more attention. In the traditional understanding of sovereignty as the property of a state deemed capable of transcending the law, he identified the survival of theological modes of thought in jurisprudence, which he set out to combat. It is, hence, around the question of sovereignty that the relationship between 
what Baume (2009: 370) has aptly termed 'Kelsen's critical political theology' and Carl Schmitt's (2015: 23) self-stylization as a 'theologian of jurisprudence' can best be examined.

As noted in the previous chapter, in Political Theology, Schmitt (2009: 46) gives Kelsen credit for having called attention to the methodological affinities between theology and jurisprudence. Kelsen, indeed, arrived earlier than Schmitt, though from a diametrically opposed direction, to the problems of political theology. In fact, he had already dealt with the parallels between God and state, theology and jurisprudence, before the monograph Das Problem der Souveränität (1920), which Schmitt cites. In a long article, published in 1914, where he seeks to elucidate, from a strict normological perspective, the old English maxim that "the king can do no wrong," Kelsen remarks that the notion that the state, which is merely the personification of the legal order, could incur in illegality is as antinomic from the viewpoint of legal science as the idea of a sinful God from the perspective of theology. Furthermore, and crucially, he adds that while theology can perhaps gloss over the antinomy by referring to the 'metalogical and transrational nature' of its ultimate concepts, jurisprudence has no such privilege - a doubtful privilege, of course, in Kelsen's view - and must therefore dismiss the idea of state illegality as an 'illogical monstrosity' (Kelsen, 1968e: 972) ${ }^{29}$ But the instance where Kelsen's investigation and critique of the analogies between both the concepts of God and state and the disciplines - theology and jurisprudence-which study them are most forcefully summarized is the famous essay on 'God and the State,' published roughly at the same time as Schmitt's Political Theology. ${ }^{30}$

'God and the State' is divided into two parts. In the first one, citing Feuerbach, Durkheim and Freud, Kelsen dwells on the parallels between the social and religious problems. According to him, the concepts of society and the state appear to the individual very much in the image of God, that is, as an authority demanding complete obedience. The unconditional submission to a higher authority that characterizes the religious experience is perfectly identical with the subordination of the individual person to the imperative injunctions of society (Kelsen, 1973: 64). Here, instead of seeking distance and drawing strict borders, Kelsen makes common cause with the empirical sciences of sociology, biology and, especially, psychology, praising them for having uncovered the fundamental affinity between the basic elements of social authority and religious authority. Indeed, as we have already noted, this is not the only instance where Kelsen shows particular appreciation for the achievements of Freudian psychology, which provide 'invaluable preparatory work' towards 'overcom[ing] the theological method in the humanities and especially in the social sciences...by dissolving the hypostatizations of God, society and the state in their individual-psychological elements' (Kelsen, 1968d: 214). ${ }^{31}$ 
The second part of the study, however, is much more significant in light of Kelsen's chiefly epistemological and methodological purposes than the preceding eulogy of the empirical, social scientific exposure of the realities of domination, which the ideological discourses of social and religious powers seek to conceal. Here, the argument is that the traditional Staatslehre exhibits striking similarities with theology in its conceptual foundations and modes of thought. As the Austrian jurist sees it, the fundamental problem with the concepts of God and state, as they are understood by theology and traditional jurisprudence, is their emergence as personifications unduly turned into reifications or hypostatizations of an abstract idea of unity:

If the person, created by legal cognition to symbolise the unity of the legal system, and called "the state," is hypostatised in the usual way and set up as a special entity over against the law — of whose unity this personified state is a mere expression - we then have exactly the same problem-or pseudo-problem-situation as in theology. The latter can exist as a discipline distinct from moral or natural science only insofar as it clings to God's transcendence over the world - this fundamental dogma of all theology - to the existence of a supernatural God above and beyond the universe; just as a theory of the state distinct from legal theory is likewise possible only so long as we believe in the transcendence of the state vis-à-vis the law, in the existence, or more exactly the pseudo-existence, of a metalegal, supralegal state.

(Kelsen, 1973: 70) $)^{32}$

For Kelsen, the analogies between both reifications - of God and stateare numerous. From a critical epistemological perspective, however, the problem is one and the same: Hypostasis leads to the duplication of the object of knowledge, which, in turn, results in unfathomable contradictions. For instance, the omnipotence of the theological God evinces the same logical structure, and the same logical flaws, as the traditional understanding of state sovereignty. Both concepts suggest absolute power, but such power is then paradoxically restricted, by an unexplained and unexplainable self-limitation, to the moment of creation of, respectively, the natural and the legal orders. The logical inconsistency is plain to see. A God that cannot alter the natural order it has created is hardly an omnipotent deity, just as a state that cannot interfere in the legal order after establishing it cannot claim to be sovereign in the usual sense of the word. To square this circle, Christian theology and traditional jurisprudence employ formally equivalent theories, composed of two distinct moments. The first step is that of voluntary submission to the created order. In theology, this happens when God assumes human shape, when a scission occurs between God, the almighty father, and His human son, 
who despite being of divine provenance, is nevertheless bound by the laws of nature. Traditional legal theory, for its part, postulates the principle of the voluntary commitment of the state to the legal order it has sovereignly created, in order to explain the mysterious 'metamorphosis of the state as power into the state as law' (Kelsen, 1973: 74). The subsequent step, then, is marked by the exceptional transgression of the created order. The concept of miracle, which denotes a momentary, divinely imposed suspension of the laws of nature, allows theology to reaffirm God's omnipotence and transcendence. In a similar move, legal theory reasserts the sovereignty of the state by allowing it, in the presence of extraordinary circumstances, to step beyond - partially or totally annulling - the extant legal order.

Dictatorship is hence, for Kelsen (1973: 78) as well as for Schmitt, 'a legal miracle.' However, in stark contrast to the self-proclaimed 'theologian of jurisprudence,' the Austrian thinker appears here overtly as a sort of epistemic anarchist (Kelsen, 1973: 80-81). ${ }^{33}$ For him, the notion of a 'legal miracle' is a disparaging one, which indicates the inexcusable capitulation of legal theory to theological modes of thought in its attempt to explain — and to justify —in supposedly legal terms that which is juristically inconceivable. In this context, the question concerning the relationship between such epistemic anarchism and political anarchism proper unavoidably emerges. To solve it, Kelsen employs his favourite argumentative move, making use of the dualism of Sein and Sollen to differentiate between an ethical-political anarchism which argues that there ought to be no state - an anarchism which he of course rejects - and an epistemic anarchism which asserts that there is no state as an absolute, transcendent reality, but only as a personified mental construct which means nothing but the unity of the legal system. ${ }^{34}$ Indeed, by reducing the concept of the state to that of the immanent, self-posited legal order, the pure theory of law, as Kelsen concludes, aims to rise above theology to the level of a modern science:

This purely legal theory of the state, which gets rid of the idea of a state distinct from law, is a stateless theory of the state. And however paradoxical it may sound, it is only by means of it that legal and political theory first push forward from the level of theology into the ranks of modern science. The concept of the state evolved by the older political and legal theory stands epistemologically-like the concept of God-on a par with the concept of the soul in the old psychology, or the concept of force in the old physics. The state as a person could equally well be called the soul of the law or the force of the law. Like God, soul and force, it is a substance-concept. Since modern science seeks everywhere to dissolve substance into function, and has long since thrown the concept of the soul overboard, along with that of force, modern psychology has become a soulless 
theory of the soul, and modern physics a forceless theory of force. And if the absorption of the concept of a supernatural God by the concept of nature was the presupposition, first created by pantheism, for a genuine natural science devoid of all metaphysics, so likewise is the reduction of the supralegal concept of the state to the concept of law the indispensable precondition for the development of a genuine science of law, as a science of positive law purified of all natural law.

(Kelsen, 1973: 81-82) 35 $^{35}$

Thus, according to Kelsen, modern science, by refusing to conceive its constitutive concepts as transcendent, meta-scientific realities, avoids the unsounded contradictions that arise from an abusive duplication of the object of cognition. Modern legal theory, that is, Kelsen's pure theory of law, rejects a state that purports to be more than the name for the unity of the legal system, just as modern psychology disposes of a soul which is more than a sign for the human mind-body complex, and as modern physics ignores a force exogenous to the physical world as constituted by its concepts. The anti-metaphysical thrust of Kelsen's legal theory culminates in a quest for self-posited immanence that the author identifies with the broader project of modern science.

\section{On the Limits of Legal Immanence: The Basic Norm}

This restriction of the science of law to a self-posited and self-contained system of positive norms which regulates its own reproduction seems to allow Kelsen to circumvent the vexing issues, from a normological perspective, of an empirically conceived legitimacy distinct from formalrational legality (Weber), on the one hand, and of a sovereign who creates law from a normative void (Schmitt), on the other hand. What Kelsen seeks to assert, and this alone assured him of the scientific autonomy of jurisprudence, is a pure sphere of legality, where only positive law can create and apply positive law, free from empirical considerations and metaphysical presumptions. Where does legal validity come from? It can only come from a positive norm, whose own validity, in turn, proceeds from another, more abstract positive norm to which it can be imputed, and so on. The whole realm of law, from simple administrative measures and everyday judicial decisions at the bottom to the constitution at the top, is thus unified into a formally gapless, hierarchically organized system, which nevertheless, from the point of view of the content of its normative material, need not be a contradiction-free system (Kelsen, 1992: 63-70). While the "downwards" autopoietic unfoldment and expansion of this system generates no theoretical problems, at the top of the pyramid, at the end of the chain of validity/imputation, a point must be reached where, unavoidably, a positive norm-indeed, the highest positive norm of all-can no longer be imputed "upwards" to another positive norm. 
Therefore, to the extent that it cannot be traced back to a superior positive norm, the legal validity of the highest norm in the system seems to rest on shakier foundations than all the other, hierarchically inferior norms. This is the difficulty Kelsen seeks to capture and solve through the concept of the Basic Norm (Grundnorm).

There are different formulations of the concept of the Basic Norm across Kelsen's vast $x u v r e$. For instance, in his critique of the Heidelberg neo-Kantians analysed earlier, it is rendered as the maxim 'you ought to obey the orders of the prince or the laws of the state' and termed 'the "reconstructed legal norm" in an enhanced sense of the word' (Kelsen, 1968a: 75). ${ }^{36}$ However, as Koskenniemi (2001: 241) rightly observes, it arises in its keenest form in the Introduction to the Problems of Legal Theory, the apex of Kelsen's transcendental phase. The Basic Norm is the conceptual instrument devised by the Austrian jurist to answer the question of 'what accounts for the unity of a plurality of legal norms' (Kelsen, 1992: 55). 'A plurality of norms,' he continues, 'forms a unity... if the validity of the norms can be traced back to a single norm as the ultimate basis of validity' (ibid.). The Basic Norm is this ultimate, single norm, which constitutes the system as a self-contained and self-posited order. According to Kelsen, there are two different kinds of normative systems, discernible by the nature of their Basic Norm. On the one hand, normative systems of a moral kind possess a substantive Basic Norm, 'under whose content the content of the norms forming the system is subsumed, as the particular under the general' (ibid.). A crucial aspect of such systems is, thus, their 'static character,' evinced by the circumstance that one can derive all particular norms from the content of the Basic Norm 'by way of a deduction from the general to the particular' (Kelsen, 1992: 56). Legal norms, on the other hand, can be known to compose a system only by significantly different, purely formal means:

The validity of a legal norm cannot be called into question on the ground that its content fails to correspond to some presupposed substantive value, say, a moral value. A norm is valid qua legal norm only because it was arrived at in a certain way-created according to a certain rule, issued or set according to a specific method. The law is valid only as positive law, that is, only as law that has been issued or set... The basic norm of a positive legal system...is simply the basic rule according to which the norms of the legal system are created; it is simply the setting into place of the basic material fact of law creation. This basic norm, the point of departure for a process, has a thoroughly formal, dynamic character. Particular norms of the legal system cannot be logically deduced from this basic norm. Rather, they must be created by way of a special act issuing or setting them, an act not of intellect but of will.

(Ibid.) 
This fundamental "act of will," however, must crucially be understood as will to knowledge, and more specifically, as will to juristic normative knowledge, if it is not to succumb to the pitfall of tracing an Ought back to an Is, to an empirical will. In that sense, the Basic Norm performs a strictly epistemological function. It constitutes, in Kantian parlance, the transcendental condition of possibility of a positive legal science. 'The Pure Theory of Law,' states Kelsen (1992: 58), 'works with this basic norm as a hypothetical foundation,' as the presupposition that allows the jurist to interpret the normative material presented to him or her 'as a system of legal norms.' Indeed, far from creating a wholly new approach to law, the theory of the Basic Norm is 'an attempt simply to reveal the transcendental logical conditions of [a] long-standing method of cognizing positive law' (ibid.). Or, as Koskenniemi (2001: 241) perceptively puts it, the Basic Norm is simply 'a norm which one needed to believe valid in order that everything that one already knew about the legal system should be true. ${ }^{37}$

Notwithstanding Kelsen's insistence on the strictly transcendental status of the Basic Norm, his theory invites in this regard a charge that every self-posited system of pure idealities grapples with, namely, the charge of Platonism. After all, according to Kelsen, are not norms in general, and legal norms in particular, abstract objects that do not exist in space or time-objects of the mind and not of nature? And also, though in a different manner, is not the reasoning behind the idea of the Grundnorm starkly reminiscent of Aristotelian metaphysics, in the sense that it traces the unity of a self-contained system back to a constitutive first principle, to an "unmoved mover?" Despite Kelsen's anti-metaphysical inclinations and his - somewhat crude - critique of Platonic and Aristotelian justice (Kelsen, 1957: 82-136), the theory of the Basic Norm can hardly avoid getting entangled in the issues that have preoccupied Western metaphysicians for millennia. To be sure, Kelsen was adamant_indeed, much more adamant than Kant himself - in opposing the conflation of truth, justice and beauty that Western thought inherited from Greek philosophy. However, does not his theory of the Basic Norm amount to placing a norma sui alongside and as a distinctively legal-normative type of causa sui? And does not this, in turn, raise the suspicion, if not of scholasticism, then at least of metaphysical Spinozism (Aurélio, 2015)? ${ }^{38}$

It seems to me that the only plausible, albeit not fully convincing, way of relieving the doctrine of the Grundnorm from these charges is to stress its purely arbitrary nature as an "act of will" to juristic knowledge. To ground the possibility of pure legal cognition, the Basic Norm imposes an arbitrary and artificial border that isolates the precinct of law from the contiguous spheres of empirical power, on the one hand, and morality and justice, on the other hand. That Kelsen himself recognizes the arbitrariness of such a procedure becomes patently clear as soon as he starts to consider the content of the Basic Norm, i.e. as soon as, for the 
sake of grasping concrete normative materials from a legal perspective, it becomes necessary that the Basic Norm means more than a contentless 'hypothetical foundation' for juristic cognition. When Kelsen directs his glance at the state legal system, the fluid shading of empirical power into law is unmistakably acknowledged. Conversely, when he expands his perspective of legal unity to include international law, the universalist and cosmopolitical, rather than purely scientific and ideologically neutral, underpinnings of his legal theory emerge in full glow. Given that we are chiefly interested in Kelsen's theory of democracy, which the author implicitly restricts to nation-state-bounded legal systems, for the remainder of this section, we will focus on the former. The latter will be dealt with afterwards, when we consider the tensions inherent in Kelsen's Weltanschauung. ${ }^{39}$

The critique of Kelsen's Grundnorm that Carl Schmitt formulates in the beginning of his Constitutional Theory must be taken seriously even by those - the author of these lines included - who would side with Kelsen any day in the disputatio between the two jurists. Schmitt (2010: 8-9) sees Kelsen's doctrine 'as the last offshoot of the real theory of the bourgeois Rechtsstaat,' a mitigated, derivative variety of bourgeois liberalism that has lost the strength to believe in natural or rational law, 'in a real Ought,' and instead believes only in the validity of 'positive norms, i.e. those, which are actually valid,' thus succumbing into 'the tautology of a raw factuality. ${ }^{40}$ And indeed, looking at the concrete case of any given state legal order, the metalegal Basic Norm must be conceived either as that which flows from empirical power relations, and thus ultimately as no norm at all, or as stemming from a non-positive, absolute ethical or political norm. It is impossible for Kelsen to win the war on both fronts: To disentangle the law from the orbit of metaphysics, he must veer towards empirical reductionism; to uphold the strict distinction between Is and Ought, he would have to recognize the primacy of a non-positive normativity, to which positive law must submit. Either he remains a positivist, but gives up on normativism, or he remains a normativist at the expense of positivism. One way or the other, the autonomy of positive law relative to both empirical fact and absolute value can hardly be maintained. Considering the content of the Basic Norm of a state legal system, Kelsen's veering towards empiricist positivism is plain to see when he invokes the case of a revolutionary regime change:

A band of revolutionaries stages a violent coup d'état in a monarchy, attempting to oust the legitimate rulers and to replace the monarchy with a republican form of government. If the revolutionaries succeed, the old system ceases to be effective, because the actual behaviour of the human beings for whom the system claims to be valid corresponds no longer to the old system but, by and large, to the new system. And one treats this new system, then, as a legal system, that is to say, one interprets as legal acts the acts applying the new system, 
and as unlawful acts the material facts violating it. One presupposes a new basic norm, no longer the basic norm delegating lawmaking authority to the monarch, but a basic norm delegating lawmaking authority to the revolutionary government.

(Kelsen, 1992: 59) $)^{41}$

At the end of the day, only 'the actual behaviour of human beings' can signal the advent of a new Basic Norm. Here, Kelsen remains a positivist. Yet at the root of his positivism lie not norms, but empirical regularities, which proceed from the crystallization of de facto patterns of domination. After using the example of revolutionary regime change to solve the question of the content of the presupposed Basic Norm, Kelsen cannot help but be at pains to maintain a strict distinction between Sein and Sollen, between empirical efficacy and legal validity. He claims that, for the concept of a legal order to any make sense at all, one must acknowledge the possibility of a discrepancy between that order and the realm of empirical events it aims to regulate (Kelsen, 1992: 59-60). This is beyond dispute, for no Ought would be needed if the Is always fully corresponded to it. However, to recognize the ineradicable mismatch between legal order and empirical reality is not a persuasive vindication of the full autonomy of the legal-normative sphere. When it comes to the crucial issue of the origins of a concrete state legal order, the validity of the system is ultimately explained by a degree of conformity inferable from empirical patterns of behaviour. The science of legal positivism, from this perspective, finds its foundations established by the empirical realities of power and domination. By doing so, it invites the same criticism as Weber's sociological conception of legitimacy, namely, that of having replaced the old, no longer tenable metaphysical certainties of natural law by a crude factualness. Paulson (1992: 332) concludes his thoughtful analysis of the neo-Kantian dimension of Kelsen's legal theory by suggesting that, even if the transcendental argument fails - as it patently does-Kelsen's theory can still fruitfully be interpreted as a sound exposition of a legal 'scheme of analysis,' of a distinctly, though not unique, 'legal point of view. ${ }^{42}$ And that may very well be the case. But only on the condition that, along with its claim to uniqueness, also the claim to full autonomy, with its almost fanaticaland ultimately hopeless - insistence on the strict caesura between law and the neighbouring disciplines of moral and political philosophy, on the one hand, and empirical politics, on the other hand, be abandoned.

\section{What Is the People and How Can It Will? Kelsen's Democratic Pluralism}

Kelsen's democratic thought, to which we now turn, cannot be understood in isolation from his legal theory. However, the few scholars who have studied the former in depth, even if they stress in one way or another that it 
proceeds naturally from, and is incomprehensible without reference to, the latter, also point out as an unfortunate circumstance that it has hitherto received far less attention (Weinberger, 1982; Dreier, 1986; Ehs, 2009; Baume, 2012). From Kelsen's approach to the problems of legal theoryand particularly from its anti-metaphysical thrust-emerges, without surprise, a theory of democracy that is critical of substance-concepts, eager to expose delusive hypostatizations and always ready to lay bare the fictions which hide behind tightly erected ideological façades. If democracy designates a state form, it must share the general features of the state as defined by Kelsen's pure theory of law. The democratic state appears, hence, as the expression of the systematic unity of a democratic legal order, as an abstract point of imputation to which the actions of its agents or organs are attributed. Notions of direct popular rule are therefore discarded at the outset. The state is a multi-layered complex of intermediation, and only representation or delegation can bridge the gap between the constitutional pinnacle of the order and the manifold administrative measures and judicial decisions taken by street-level officials. As Kelsen (1968f: 217) puts it in one of his many texts from the 1920s on the contrast between natural law and positive law, stressing the dynamic nature of the latter in opposition to the static character of the former, 'the unity of the dynamic system' of positive law_or, which is the same thing, of the state - 'is the unity of a chain of delegation. ${ }^{, 43}$

This conception of the state lies at the core of Kelsen's critique of the doctrines of representation traditionally advocated by political thought and public law. In contrast to them, Kelsen builds an alternative theory based on the legal concept of delegation (Delegation or Stellvertretung instead of Repräsentation). Delegation describes a situation in which, by virtue of an authorizing positive norm, an agent acts on behalf of a third party. This is an exception, usually due to spatial and temporal constraints, to the general rule that expressions of will bind the person-natural or artificial, to use Hobbes's (1651: chap. XVI) classical distinction - who enunciates them, rather than some other, physically absent entity (Kelsen, 1925: 311-312). Political representation, according to the Austrian jurist, is no different. In modern constitutional democracies, where parliament is said to represent the people, one should therefore come across a positive norm stating that, as a general rule, the people possesses lawmaking authority, further specified by another positive norm allowing parliament to legislate in lieu of the people in strictly defined circumstances. However, in no modern democracy is that the case. Quite on the contrary, modern constitutions tend to place legislative authority entirely in the hands of the-more or less-democratically elected parliament. The people is thus de jure excluded from direct intervention in the lawmaking process, since virtually all constitutional texts guarantee the independence of parliament and reject the imperative mandate. To speak of a representation of the people by parliament in such circumstances is, 
in Kelsen's view, nothing but an ideological fiction that stands in sharp contrast to the content of positive law. The purpose of the fiction is to maintain the illusion that the people, even if positively excluded from direct participation in the legislative process, has not completely alienated its original legislative authority and capacity. Parliamentary rule is thus justified from the point of view of popular sovereignty, and the tensions emanating from the difficult matrimony between liberalism and democracy are, at least superficially, appeased (Kelsen, 1925: 312-315). Kelsen's critique of liberal theories of parliamentary representation shows that his science of legal positivism, notwithstanding having abstract idealities as its object of enquiry, shares to a certain extent the capacity, which the author praises as an attribute of the empirical social sciences - and, among them, especially psychology - to see through ideological mystification. Indeed, in this case, it underscores the distance, which liberal ideology seeks to conceal, between popular rule and parliamentary rule.

However, neither Kelsen's analysis of the parliamentary system nor, more generally, his philosophy of democracy should be reduced to his legal theory, as if they merely applied the latter's fundamental premises to a specific problem. In fact, as will be shown in the following pages, Kelsen's theory of democracy (1) has a philosophical breadth which, perhaps surprisingly, extends beyond the stringent neo-Kantian framework of his legal theory; and (2) reveals a sociological acumen that one would perhaps not expect from a legal theorist who, if not an outright 'enemy of sociology' (Spann, 1922: 199), at least ventured to deny it the kind of scientific autonomy he vindicated for the domain of law.

\section{The Ghost of Jean-Jacques}

Kelsen's theory of democracy was first laid out, in a tightly argued yet comprehensive fashion, in Vom Wesen und Wert der Demokratie, originally published in 1920. The text appeared first in an article format, in Heidelberg's Archiv für Sozialwissenschaft und Sozialpolitik, and was republished in the same year as a brochure by Paul Siebeck's publishing house in Tübingen. In 1929, a second, revised and substantially enlarged edition followed. In these texts, Kelsen writes neither as a legal theoristthough the attentive reader should keep the basic tenets of his legal theory in mind-nor as an expert in constitutional law, but both as a political philosopher, who wishes to restore theoretical depth to an often used and abused concept, and as a partisan of the parliamentary-democratic regime, whose establishment in post-war Austria he had contributed to by drafting a new constitution and serving as a judge, with life tenure, in the constitutional court. Kelsen's (1920: 3-4) immediate political concern was the split in the social-democratic camp between those who sought to harmonize socialism and democracy and those who called for a revolutionary dictatorship of the proletariat. ${ }^{44}$ 
In the initial pages of Vom Wesen und Wert der Demokratie, where the Austrian scholar considers the idea rather than the reality of democracy, those familiar with the author's legal theory might justifiably be puzzled to encounter a reference to Jean-Jacques Rousseau as 'perhaps the most important theorist of democracy' (Kelsen, 1920: 6). Indeed, while it comes as no surprise that Schmitt (2010: 230), even if he interpreted it quite one-sidedly in light of his own conception of democracy as substantial homogeneity, saw in Rousseau's theory of the general will 'the strongest and most coherent expression of democratic thought,' Kelsen's self-declared Rousseauian inspiration evokes, with good reason, a sense of bewilderment. After all, is not the doctrine of the general will a paramount instance of hypostasis, of inadmissibly ascribing concrete reality to an abstract idea?

Kelsen locates the essence of democracy in the idea of freedom. More precisely, he traces it back to freedom understood as the sheer negation of society, as an innate individual disposition to anarchy, as a natural human impulse to rebel against the coercive injunctions of the social order, 'against the torment of heteronomy' (Kelsen, 1920: 4). This elemental instinct of freedom, which Kelsen assumes as an 'anthropological premise' (Mock, 1982: 442), ${ }^{45}$ is subsequently complemented — and modified-by the principle of equality. This occurs when the freedom-seeking individual discovers her or his subordination to the extraneous will, not of a deity, but of fellow human beings. The primordial call for freedom is thus rephrased as a cry of protest against the domination of man over man: 'He is a human being like me, we are equal! So where lies his right to rule me?' (Kelsen, 1920: 4). ${ }^{46}$ The synthesis of the ideas of freedom and equality combines, therefore, two fundamental negations: in a first moment, the rejection of political rule tout court; subsequently, the refusal of its exercise by human beings over other human beings. The problem Kelsen faces, in this sense, is analogous to that which Rousseau sought to solve in The Social Contract, namely, that of reconciling such a raw material of radical negativity with the defence of a legitimate republican, that is, democratic, political order. ${ }^{47}$

However, the Genevan philosopher himself admitted that a true democracy was nowhere to be found, the ideal being too demanding to put into practice (Rousseau, 1797: 266). Quite unsurprisingly, therefore, most constitutional lawyers and democratic theorists in the German-speaking context who shared Kelsen's concerns about the fate of parliamentary democracy in the interwar period-from the conservative-leaning Erich Kaufmann, who authored an incisive critique of neo-Kantian legal philosophy (Kaufmann, 1921), to the social-democrat Hermann Hellersaw Rousseau's teachings more as obstacles than as helpful means to meet the challenges of modern democracy (Pasquino, 1995: 122). Ultimately, in Kelsen's case, too, the inspirational force of the Rousseauian conception of freedom soon starts to wear away, as the Austrian scholar 
seeks to close the gap between the idea of democracy and its institutional realities. In fact, Kelsen's reflections on the synthesis of freedom and equality, though they appear to be of a highly abstract, purely speculative kind, include from the very beginning considerations of empirical viability. According to him, indeed, 'experience shows that if we want to remain equal in reality, we have to let ourselves be ruled' (Kelsen, 1920: 5). Democracy is a form of domination (Herrschaft), not the promise of a horizon beyond domination. This means that the paradox of the idea of freedom, which emerged simultaneously as the primary source of democracy, understood as a form of political order, and as the very negation of social order, must somehow be resolved. For the first step towards the necessary transformation of the idea of freedom, the Rousseauian vision of the social contract, of the leap from nature to society, still serves as Kelsen's model:

The immense significance of the idea of freedom in political ideology can only be explained by the extent to which it flows from a deep source in the human soul, from that primeval subversive instinct which places the individual against society. And yet, in an almost enigmatic self-deception, the idea of freedom becomes the mere expression of a particular position of the individual within society. The freedom of anarchy turns into the freedom of democracy.

(Kelsen, 1920: 5-6). ${ }^{48}$

Kelsen does not interpret this transformation as an unambiguous triumph of reason over instinct and nature. There is an element of illusion, 'an almost enigmatic self-deception,' involved in the redefinition of freedom as the property, not of individuals, but of a construed collective subject. The freedom of democracy comes to designate a free state, where the individuals participate in the creation of the order they must submit to (Kelsen, 1920: 10-11). However, the right to participate in the creation of the social order, the criterion that distinguishes democracies from autocracies in Kelsen's twofold typology, does not exclude the possibility of a dissonance between the particular, subjective will of individuals and the objectively valid will of the state. When this happens, the Austrian thinker, still faithful to Rousseau, argues that the individual, qua citizen, can only be free by conforming, or being forced to conform, to the general will that determines the content of the social order (Kelsen, 1920: 12, n. 11).

But how is the general will of the democratic state actually formed? In theory, one could hope to reconcile both dimensions of freedomindividual and collective, natural and social — by making unanimity a precondition for the validity of the democratic social order. That would be, indeed, the Rousseauian solution. If the social order is the product of a covenant agreed to by all the members of the community, its collective will coincides with the subjective will of all individuals, i.e. there 
is a perfect match between the volonté générale and the volonté de tous. Here, however, Kelsen displays a practically oriented, "realist" approach that makes him discard unanimity. For him, the closeness of unanimity to the original democratic idea of freedom is of a strictly speculative, ahistorical nature. In the reality of social life, there is no state of nature which could be conceived as a ground-zero point of departure for the establishment of social order. Everyone is born and raised within some concrete order, whose coercive injunctions often clash with the subjective will of individuals. In question is never the ex nihilo foundation of the social order, but merely the change or maintenance of its contents. In historically situated conditions, the limitations of unanimity are strikingly obvious: A small minority could thereby block the will to change of an overwhelming majority. Instead of unanimity, it is the principle of majority that emerges for Kelsen (1920: 8-10; 1925: 323-325) as the most compelling achievable compromise between individual freedom and the existence of a social order.

However, Kelsen's methodological critique of hypostasis, of the mistaken assumption that there is a concrete substance or an underlying reality beneath the personified abstractions of God, the state or the people, also clearly sets him apart from Rousseau. For Kelsen, the people, too, is an ideality, a mental construct with no real, empirical existence, which can thus have no will in a literal, physical-psychological sense. From a Kelsenian perspective, Rousseau's famous refusal of representation of the sovereign general will can only be interpreted as a hypostatized conception of the latter. For Rousseau (1797: 228), either the sovereign people itself or some other entity, be it a monarch or a parliament, voices its own will; it is impossible for the latter to express the will of the former. ${ }^{49}$ This type of reification, as Kelsen's legal-theoretical writings abundantly denounced, was pervasive in the traditional German theory of public law. Georg Jellinek (1906: 62), for instance, took Rousseau's hypostatization of the general will to naturalistic extremes by arguing that one cannot will for someone else just as one cannot eat or drink for another person. Kelsen's theory of democracy, informed by his legal theory, rejects this misleading naturalization of abstract constructs and maintains, as we have noted earlier, that representation must be understood as a normative chain of delegation tying together the different, hierarchically structured parts of the legal system.

In sum, concerning Kelsen's claimed Rousseauian inspiration, Pasquino (1995: 124) comes to the fitting conclusion that it boils down to a ghostlike 'armour of a non-existent knight.' The concept of popular sovereignty has no place in Kelsen's theoretical edifice, and his defence of democracy must draw its intellectual resources from elsewhere. Instead of deriving democracy from the ideas of freedom and autonomous, popular self-rule, Kelsen comes to see it, in essence, as the political expression of a more general relativistic persuasion. Inevitably, relativism shifts him, 
albeit unwittingly, from the philosophical orbit of Rousseau to that of Hobbes, a move also prompted by his stringent legal positivism. After all, any coherent legal positivist must adhere to the Hobbesian maxim auctoritas, non veritas, facit legem, in the specific sense that, to the positivist, legal authority stems only from positive law and is wholly independent from prescriptive ethical or political, absolutely valid truths. In contrast to Hobbes, however, Kelsen draws moderate democratic consequences from relativism. The relativist argument for democracy allows Kelsen, as we will see in the following lines, to bridge the gap-which ironically, however, his legal theory so violently fought to preserve-between the normative idea of democracy and its empirical, sociological deployment. Moreover, as further analysed in a subsequent section, the relativist argument brings democracy closer to Kelsen's progressive-scientific worldview. ${ }^{50}$

\section{Relativism and Pluralism: Kelsen's Defence of Political Parties and Parliamentary Democracy}

The relativist argument emerges distinctly towards the end of the first edition of Vom Wesen und Wert der Demokratie, where the author states that democracy,

[b]ecause it weighs everyone's political will equally, must also respect each political belief and opinion...in equal measure. If one renounces to the knowledge of an absolute value, the opposite opinion to one's own must also be deemed possible. Relativism is therefore the worldview presupposed by the democratic idea.

(Kelsen, 1920: 36). ${ }^{51}$

However, in the second edition of that work, the relativist argument appears earlier in the text, in connection to the practical institutionbuilding challenges of modern democratic states. Here, Kelsen specifies the democratic concept of the people by moving downwards in the ladder of abstraction from the ideal normative notion of unity, switching to a sociological perspective that takes into account the antagonistic, politically active individuals and groups. In this quest for the people as empirical reality, the author encounters what he sees as one of the most important elements of democracy as it actually exists: the political parties (Kelsen, 1929: 19).

At the time, in Germany as elsewhere, the political parties were largely ignored by positive constitutional law and looked upon with suspicion by the dominant state law doctrine. Quite revealingly, the word "party" appears only once in the text of the Weimar constitution, and in a derogatory sense, when its article 130 states that 'officials serve the community, not a party. ${ }^{52}$ The prevailing view among constitutional theorists, in 
turn, stressed the tension between the state understood as embodiment of political unity, on the one hand, and party pluralism and antagonism, on the other hand. For the dominant opinion, the political parties, as vehicles of particular interests and carriers of divisive socio-political identities, could never be harmonized with an entity - the state - that was imagined as capable of transcending all such differences, of building a real unity out of them. Kelsen (1929: 166-172, ns. 16-19) targets Heinrich Triepel, founder of the Association of German Constitutional Law Professors, whose 1927 address as the rector of the University of Berlin dealt with the state constitution and the political parties. ${ }^{53}$ Kelsen sees in Triepel's anti-parties stance the cheap semantic games of traditional conceptual jurisprudence (Begriffsjurisprudenz) at work, which consisted in deducing from the nature of the state everything one deemed politically desirable and, conversely, dismissing as incompatible with such nature what one took to be politically undesirable. In this regard, Carl Schmitt's critique of pluralism, which we analysed in the previous chapter, converged in essence with the mainstream view represented by Triepel. Schmitt, too, posited an irreconcilable opposition between the concepts of state, i.e. the people as a political unity, and party pluralism, interpreted as a unity and state-dissolving force. Indeed, in his critique of British pluralist theory, Schmitt (1994: 152) formulates this quite graphically: 'the parties slaughter the mighty Leviathan and each cut out from his body their own piece of meat. ${ }^{54}$ In Kelsen's view, however, these rhetorical tricks and vivid images amounted to no more than a poorly disguised opposition to democracy itself, or, to put it more precisely, to democracy as it could be achieved in modern polities. For the Austrian scholar, the presupposition of a somehow discernible, unifying general interest, of a common good, was simply a 'metapolitical illusion' (Kelsen, 1929: 22). If the legislative will of the state shall voice more than the views of a single dominant group, then there is no alternative to having it derived from the ever-shifting compromises between contending material and ideal interests, represented precisely by the political parties. Therefore, the attempts to formally recognize the parties in positive constitutional law, as well as to constructively reflect upon their meaning for constitutional theory, were more than justified. In Kelsen's (1929: 20) own words, 'democracy is necessarily and inevitably a state of parties. ${ }^{, 55}$

This understanding of democracy has far-reaching implications for the theorization of political unity. As Aurélio (2009: 47) keenly argues, unity is thus reinterpreted in intrinsically plural terms, in sharp contrast to the monistic orientation which characterizes state theory in the social contract tradition. Indeed, both Hobbesian autocracy and Rousseauian democracy sought to overcome the pluralism of the state of nature by conceiving - and reifying - sovereignty in the image of the psychophysical individual who is one with his own indivisible will. The sacred person of the sovereign, either identical with a natural person or taking the form 
of an assembly, hence supersedes the multiplicity of the reciprocally hostile, or simply confusing and as such intractable, wills that held sway in the state of nature. Kelsen's Parteienstaat, on the contrary, renounces what he sees as the fiction of a real, substantial unity. The unity of the democratic state order is a property of its abstract, normative dimension only, and in reality, it constitutes the product of the compromises between the irreducibly plural political forces that are sociologically active within its physical-geographical borders. Instead of transcending it, the democratic Parteienstaat reflects the immanent pluralistic diversity of political reality.

In addition, relativism allows Kelsen to elaborate a justification of basic human rights without recourse to arguments stemming from the natural law tradition. This is what some of his critics fail to see, when they argue that Kelsen is unable to show why respect for individual rights should impose restrictions on the democratic principle of majority rule. Koller (1982: 323-325), for instance, treats the defence of individual rights as a purely ad hoc addition to Kelsen's theorization, an addition which, according to this commentator, rests simply on the empirical observation that, in constitutional democracies, majority rule seems not to be incompatible with the protection of minorities. Quite differently, however, instead of grounding rights upon a metaphysically inspired conception of human nature, Kelsen (1920: 36) obtains them as corollaries of the epistemological impossibility of 'knowledge of an absolute value. ${ }^{56}$ Since human cognition cannot know the supreme good and arrive at a definitive hierarchy of values, no majority, however large, must be allowed to impose restrictions on the free expression of ideas and beliefs by individuals and minority groups. This justification of rights from an epistemological standpoint also explains why, to the dismay of many liberals, Kelsen does not include the inviolability of private property in his list of fundamental rights. Because it is not a necessary condition for formulating or adhering to values and beliefs, private property is excluded from the Kelsenian protection of rights. What must be safeguarded, from such a relativistic perspective, is in essence intellectual freedom and the rights more closely associated with it, such as liberty of thought and speech, a free press, freedom of association and assembly, and so on (Kelsen, 1929: 53-55).

Furthermore, with regard to the protection of minorities, the Austrian jurist attributed great importance to the electoral system. In contrast to both Weber and Schmitt, who were fierce critics of proportional representation, Kelsen was an advocate of this principle, which many new democracies in the interwar period adopted. Here, too, the guarantee of a high degree of political and ideological pluralism, crucial to the idea of relativism, reshapes the understanding of democratic majority rule. Kelsen points out that in simply majority, first-past-the-post electoral systems, only an arbitrary partition of the state's territory brings an opposition to parliament in the first place. However, from a formal-legal point of view, 
in most constitutional democracies, members of parliament represent the nation or the people as a whole, not the territorial district that happened to elect them. Apart from this contradiction, a more problematical circumstance emerges from the fact that, in majoritarian systems, electoral engineering may all too easily convert a minority of votes into a majority of parliamentary mandates, thus subverting the very principle of majority rule. For Kelsen, proportional representation, by aiding to paint a more accurate picture of the politically relevant cleavages within the sociologically real people, establishes the best possible bases for decisions resting on the majority principle in the main legislative chamber. Moreover, since it brings the parliamentary strength of minority political formations as close as it is democratically acceptable to that of the majority, proportional representation favours compromise solutions and coalition building over majoritarian imposition (Kelsen, 1925: 346-350). ${ }^{57}$

Finally, Kelsen's rejection of a monolithic conception of the people is also consequential for his understanding and defence of democratic parliamentary government. His endorsement of parliamentarism, indeed, is very far from an apology of the classical, nineteenth-century liberal vindication of parliamentary rule. It is, in fact, an endorsement that acknowledges an urgent need for reform. For instance, the independence and legal immunity of parliamentarians were not, according to Kelsen, essential elements of the parliamentary system, but rather archaic remnants of that system's now bygone struggle against monarchic authority. For him, indeed, the notion of a "free mandate" was a contradiction in terms, since the idea of a mandate denotes a specific - and, to some extent, necessarily restrictive-bond, and makes no sense as an expression of complete freedom and independence. To be sure, a return to the imperative mandate of medieval feudalism was out of the question, but that members of parliament should be formally — as, by and large, they were already in practice - accountable to their party was not irreconcilable, as many anxious liberals and some astute anti-liberals argued, with the nature of parliamentary representation. By allowing the political parties to emerge as the instruments through which the pluralistically conceived people would exercise a permanent control over its representatives, it might indeed be possible to reconcile the broad masses with the parliamentary principle and, thus, to further integrate them in the modern democratic project (Kelsen, 1925: 313; 1929: 40-43).

Kelsen's views on parliamentarism are summarized in a 1925 brochure published by the Vienna Sociological Society. By then, the author had already realized that the threat to parliamentary democracy came not only from the far left, but also from the extreme right (Kelsen, 1968g: 1661, 1687). There were calls to dictatorship voiced under both red and black flags, as well as ultimately autocratic tendencies disguised as neo-corporatist alternatives to parliamentarism. Against all of these, Kelsen defends the parliamentary system as the irreplaceable instrument 
allowing one to materialize as far as possible the ideal of democratic selfrule under modern social conditions. His reasoning proceeds from the definition of parliamentarism as a system leading to the 'formation of the decisive, legislative will of the state by a collegial organ, elected by the people on the basis of universal and equal suffrage, i.e. democratically, according to the majority principle' (Kelsen, 1968g: 1663) ${ }^{58}$ This system constitutes a mitigation of the primordial - the author, indeed, qualifies it even as 'primitive' (ibid.) - idea of freedom in a double sense. On the one hand, by accepting the majority principle, parliamentarism renounces unanimity in the formation of the state will, which alone would wholly correspond to the axiom of self-determination. On the other hand, by transferring legislative authority from the people to parliament, it acknowledges representative intermediation in the will-formation process, thereby reconciling democratic freedom with the requirements of the social division of labour, which Kelsen (1968g: 1664) conceives as 'the condition of all socio-technical progress.' Parliamentarism is thus, above all, a compromise solution, where the ideas of social peace and progress are substituted for the original anarchistic ideal of unbounded freedom. This means, however, that for Kelsen, parliamentarism is not in itself a political ideal, possessing an intrinsic value of its own, but rather the instrument, the specific social technique that modern societies cannot do without, if they aim to be ruled democratically.

From this perspective, Kelsen (1968g: 1684, n. 17) takes issue with Schmitt's Crisis of Parliamentary Democracy, where the German author had traced the value of parliamentary discussion to the ideology of liberalism, and argued that, with the waning of the latter, the parliamentary system was robbed of its metaphysical foundations. For Kelsen, on the contrary, parliamentarism was not inextricably tied to liberal ideology. Indeed, as an instrument to form the legislative will of the state, it could very well, depending on the composition of parliamentary majorities, lead to non-liberal or even anti-liberal policies. Schmitt was therefore wrong in insinuating that parliamentary democracy was based upon a 'metaphysical-absolutist worldview' (Kelsen, 1968g: 1685). ${ }^{59}$ The Austrian jurist's interpretation of Schmitt's critique of parliamentarism is, in all fairness, a tad too rash and simplistic here. The Crisis of Parliamentary Democracy does not argue that the liberal 'metaphysical system' is absolutistic, but rather that it constitutes a form of 'relative rationalism' that sees reason and harmony emerge, in the economic and political spheres, respectively, from free market competition and from the clash of opinions in parliamentary discussion (Schmitt, 1988: 35, 44-50). Kelsen (1968g: 1684, n. 17), to be sure, recognizes this in a footnote, but says that Schmitt, by acknowledging the relativistic aspects of parliamentary government, takes the sting out of his own argument. According to the Austrian thinker, democracy in general, and modern democratic parliamentarism in particular stem from a 'critical-relativistic basic attitude,' 
whereas all forms of dictatorship and autocracy, by contrast, have some variety of absolutistic 'metaphysical-religious belief' at their root (Kelsen, 1968g: 1685).$^{60}$ What Kelsen patently misses is that Schmitt's politicotheological approach, as we have seen in the previous chapter, operates with a broad concept of "the metaphysical" or "the theological," which encompasses Kelsen's own philosophical relativism, despite the latter's professed anti-metaphysical orientation. ${ }^{61}$

Throughout the 1920s, Kelsen appeared to be moderately optimistic with regard to the prospects of democracy as a pluralist, parliamentary Parteienstaat. Well aware of the findings of Robert Michels's (1911) influential study on mass political parties and their bureaucratic oligarchies (Kelsen, 1929: 23, n. 20), the Austrian jurist was nevertheless inclined to consider that these oligarchic tendencies could be reversed, or at least countered to a significant extent, by the formal-legal recognition of the parties as crucial instances in the process of forming the will of the democratic state. 'The constitutional anchoring of the political parties,' he argued, 'creates the possibility of democratizing the formation of the collective will within this sphere also' (Kelsen, 1929: 23). ${ }^{62}$ Whether this is a credible solution to the sociological problem of oligarchy and the challenge it poses to democracy, or merely a reiteration of the problem at another level, remains, of course, debatable. After democratizing the nineteenth-century parliamentary system by subjecting parliamentarians to party control, should one move on to democratizing the political parties by subjecting their leaders to continuous supervision by, say, formally organized factions within each party? Be that as it may, Kelsen leaves thus the door open to the possibility of subjecting the internal organization of political parties to legal regulation, which means that the Parteienstaat as he conceives it is not simply the passive replication of a self-generated elitist political pluralism.

With the rise of political extremism in the early 1930s, however, Kelsen's optimism faded. In 1929, pressure from the conservative sectors of Austrian society, which did not approve of his liberal interpretation of the right to divorce, led to his removal from the constitutional court. This prompted him to accept a professorship in Cologne, where, until the Nazis acceded to power, he would be Carl Schmitt's colleague, as well as his nemesis especially in matters of constitutional review (Kelsen, 1968h) ${ }^{63}$ In an increasingly polarized political climate, marked by the violent actions of politically motivated paramilitary groups (Berman, 1997), the relationship of the democratic authorities to the political parties and the manifold civil society organizations in their orbit became a matter of concern for those who stood on the side of the Weimar regime. Outspoken supporters of the republican order began to ponder what a democracy could do, and how far it could go, to defend itself. More specifically, they wondered about which means could be legitimately employed to oppose the self-declared enemies of parliamentary democracy, who took advantage of democratic rights and freedoms to undermine democracy. 
Kelsen's answer to these anxious concerns was crystal clear and logically irreproachable, even if arguably politically unsatisfactory.

In 1932, the Austrian jurist published a piece in the news and commentary outlet of the Staatspartei-the short-lived successor to the left-liberal German Democratic Party (DDP)—which begins with the eulogy of the Weimar constitution as 'the most democratic constitution in the world' (Kelsen, 1932: 91). Unfortunately, in spite of this quality, it was also true that no other constitution in the world was regarded with such indifference or contempt by the very people who had adopted it. In Germany, democracy was losing ground to its autocratic foes both in the party-political struggle and in the cultural and intellectual spheres. Could this trend be opposed by banning or seriously restricting the activities of parties which espoused patently antidemocratic ideologies? After all, Kelsen had already admitted the possibility of legally regulating the internal organization of political parties as key instances of democratic will formation. The effort to democratize the intra-party sphere, however, was strictly confined to the formal organization of political parties, and could not justifiably be stretched to interfere with a party's ideology or substantive political goals. To the complaint over defencelessness typically formulated by despairing democrats, Kelsen replied as follows:

[Democracy] is the one form of government which least defends itself against its opponents. It seems to be the tragic fate of democracy that it must nourish its worst enemy from its own breast. To remain true to itself, it must tolerate even such a movement which intends to destroy democracy, it must grant it the same opportunities as any other political persuasion...[W] hoever is for democracy must not allow himself to get entangled in the fateful contradiction of resorting to dictatorship to save democracy.

(Kelsen, 1932: 97-98) ${ }^{64}$

The images Kelsen uses to convey the condition of democracy in 1932 Germany are a strange mixture of resignation and principled commitment. In those days, the advocate of democracy was like the doctor of a critically ill patient, who carries on with the treatment when all hope of recovery is lost, or like a sailor who stays true to the flag as the ship sinks (Kelsen, 1932: 92, 98). This is the ultimate dilemma of a conception of democracy derived from epistemological relativism: It must accept a 'tragic fate,' if it wishes to avoid a 'fateful contradiction.'

\section{On Kelsen's Weltanschauung: Between Belief in Universal Law and Relativistic Restraint}

This dilemma is intimately connected with the tension that lies at the very heart of Kelsen's worldview. Unlike Weber, Kelsen was a man of science in the tradition of Enlightenment philosophy through and through, 
who believed in the indestructible bond of scientific and social progress. For him, modernity's disenchantment, or 'demagification' (Tschannen, 1992: 128), of the world was not tainted by the ambiguities that simultaneously fascinated and preoccupied Weber. If, indeed, there were 'two icons' (Mommsen, 1989: 3) in Weber's life, science and politics, in the case of Kelsen, science ruled supreme. The possibility, desirability and necessity of a scientific approach to nature and society, expunged from irrational subjective beliefs and metaphysical illusions, was the ultimate guiding light of Kelsen's life-work. His pure theory of law, as we saw earlier, was a self-declared attempt to elevate juristic knowledge to the level of a modern, critically grounded science. This is not to say-nothing, in fact, would be further away from the truth - that Kelsen was an apolitical man of science, who sought to impose an axiologically neutral theory of law. Rather, what one must bear in mind, to speak in Weberian terms, is that science is the cause Kelsen chose to live for. Consequently, his politics is subordinate to, and flows from, this ultimately arbitrary choice. Kelsen's justification of his own endorsement of democracy by reference to the alleged proximity of the democratic ideal to the relativistic Weltanschauung that undergirds modern science is a paradigmatic instantiation of this attitude. 'If I opt for democracy,' he states, 'I do so solely... because of the relation of the democratic form of government to a relativistic worldview' (Kelsen, 1929: 89, n. 40). ${ }^{65}$ The commitment to the cause of science, however, pushes Kelsen in divergent directions. On the one hand, his insistence on the purity, unity and autonomy of law as a scientific discipline suggests that science itself is, or should be, the value upon which a universal legal system, a truly and uncompromisingly cosmopolitan order, is founded. On the other hand, his relativistic-democratic pluralism, implicitly developed for the partial legal orders of nation-states, results in much more modest claims, eschewing impossible dreams of self-determination in favour of social peace through compromise.

The unyielding monism of Kelsen's pure theory of law prompted him to conceive of the relationship between international law and the national legal order(s) in a sharp either/or fashion. When it came to the issue of primacy, the middle ground that traditional German jurisprudence had advocated, conceiving the national and the international as autonomous normative orders, was scientifically untenable, for it resulted in the duplication of the object of juristic knowledge which, as such, would have to be one and indivisible. Either international law was superior and binding, in which case national sovereignty was a delusion, or one acknowledged the primacy of national law, in which case there was no such thing as international law at all. The choice between these two alternatives was, as Kelsen (1928: 120-124, 152-153) repeatedly notes in his critique of sovereignty, a political, not a scientific one. The author himself leaves us in no doubt as to where his sympathies stand, identifying internationalism with an objectivist and "sovereignism" with a subjectivist worldview, the 
latter with aggressive imperialism and the former with pacifism (Kelsen, 1928: 314-319). It is nonetheless doubtful whether the choice between a legal international order and sovereignty is purely political, and therefore rationally unjustifiable, or in fact ultimately supported, and perhaps even dictated, by scientific considerations in Kelsen's own logicist conception of a normative science. As we have already seen, the concept of sovereignty was, according to the Austrian jurist, plagued with logical inconsistencies taken over from metaphysics and theology. In addition, to side with sovereignty in the debate concerning the primacy of either national or international law would lead to the logically bizarre conclusion that a science of law was only possible as a science of German, French, Romanian or however else nationally determined law. Different national legal orders could be thought to stand side by side in the empirical world of power politics, but from a strictly juristic perspective, they would have to deny each other their status as legal orders, since the chain of validity/delegation did not stretch beyond the national borders of the sovereign political community. This, however, apart from rousing a siege mentality and fuelling imperialist sentiment, would actually constitute a form of methodological syncretism, for it would amount to granting the normatively arbitrary borders set up by the clash of military and political apparatuses a constitutive epistemological function for a science of norms. In other words, the choice for sovereignty would add up to taking a Sein as the ultimate source of a Sollen - precisely that which the pure theory of law fiercely opposed. The choice for internationalism, therefore, was far from being merely political. It was, indeed, the only choice compatible on logical grounds with Kelsen's legal theory. Kelsen's internationalist position reveals that, despite the jurist's best efforts to strictly separate science, on the one hand, from politics and ideology on the other hand, in his pure theory of law the logical-formal approach leads to prescriptive, cosmopolitical value-concepts, such as that of a universal legal order (Weltrechtsordnung) understood as civitas maxima (Kelsen, 1928: 241-257). This civitas maxima, as Carrino (1995: 193) keenly observes, is the positively valued 'final stage of a process of rationalization of the world, of which the pure theory of law and state is a modality.' If, thus, the idea that Kelsen's work is a politically sterile 'exercise in logic and not in life' (H. Laski apud Baume, 2012: xiii, n. 13) completely misses the mark, the contrary criticism, voiced both by conservative and by Marxist legal theorists, must be taken seriously. It seems, indeed, to be undeniable that a supposedly "objective" and value-free epistemological grounding of legal science smuggled in the promotion of a certain type of parliamentary-democratic state-even if it did not deny to autocratic states the status of legal orders-and of a specific, universalist and rules-based, international order. As Kaufmann (1921: 24) bitingly put it, Kelsen's logicism is itself restlessly metaphysical and it sails one unavoidably to the "harbour of a rationalistic and progressive metaphysics that turns pure "concepts" into metaphysical powers. ${ }^{66}$ 
Still, it would be too hasty and one-sided to interpret Kelsen's commitment to science as a radical and naïve form of scientism, which takes science to be the undisputable value upon which society should be built. Unlike the more uncompromising philosophers of the Enlightenment or the early positivists, who shared with him the belief in the modern scientific enterprise, Kelsen's late modern sobriety, contrary to what his internationalist position, read in isolation, might suggest, seeks to refrain from having science incorporate and replicate the salvific pretensions of the theological cosmologies it ventured to demystify. The powers of human reason are great, but not absolute; science has proven extremely helpful and useful for social progress, but it does not offer the key for grasping the ultimate purpose of humankind, or for making humanity attain, through progress, a state of definitive happiness. Above all, the choice for science as value is itself ultimately an arbitrary, rationally unjustifiable choice.

A more modest variety of Kelsen's scientism emerges from his democratic theory. Interestingly, indeed, in his 1925 brochure on parliamentarism, the Austrian thinker expresses reservations concerning the possible excesses of precisely the sort of uncompromising universalism advocated for in his 1920 book on sovereignty and international law. The latter ended with a plea for 'a world state as a world organization,' which 'must be set as an infinite task for all political striving' (Kelsen, 1928: 320). ${ }^{67}$ However, when confronting the argument that the application of the democratic majority principle to humanity as a whole would lead to absurd consequences, Kelsen (1968g: 1683) replies that such an objection 'does not so much touch the principle as such, but rather only its overload when centralization goes too far. ${ }^{68}$ How it might be at all possible for centralization not to go 'too far' when striving for 'a world state,' even if one conceives, as Kelsen does, the state not as an empirical object, but as a normative order-which, in any case, runs "upwards" towards a unifying source of validity at its pinnacle - is very difficult to see. Kelsen's commitment to science leads at the same time to an extremely ambitious universalism in his international thought and to a much more restrained, relativistic pluralism in his democratic theory-a bifurcation that seems hardly reconcilable.

The case for democracy as relativistic pluralism, indeed, takes as point of departure the limits to human knowledge. The impossibility of claiming for one's political ideal absolute validity, irrespective of how strongly one might subjectively be devoted to it, requires according to Kelsen a peremptory rejection of what he labels as political absolutism-be it the absolutism of a monarch, a caste of priests, a social class or a revolutionary avant-garde. While a political conviction stemming from divine inspiration might justifiably grant itself a right to impose its values upon a world of unbelievers, those who have at their disposal merely the fallible, earthly truths generated by a priori limited human knowledge can justify social coercion only by the democratic approval of the majority. 
To emphasize this point, Kelsen (1920: 37-38; 1929: 103-104; 1955: 39) includes, often as the conclusion, in all his most important texts on democracy a peculiar reading of a well-known passage from the life of Jesus narrated in the Gospel of John, which he interprets as a 'tragic symbol of relativism-and democracy' (Kelsen, 1920: 37). At Passover, Jesus is brought before Pilate and accused of pretending to be the son of God and the king of the Jews. Pilate asks him, if he is really the king of the Jews, to which Jesus replies: Yes, I am the king of the Jews and I came to this world to testify to the truth. Pilate, a sceptical Roman, wondered: What is the truth? But as he did not consider Jesus guilty of any crime, and because it was a custom to liberate a local prisoner at Passover, the Roman governor turned to the people and asked them, if he should release the self-declared king of the Jews. No, the people shouted, we want Barabbas instead - who was a bandit. Kelsen concludes, thus, with a twist:

Perhaps one might object, as a man of faith, as a political believer, that precisely this example speaks against democracy, rather than for it. And such objection must be accepted, though of course only on one condition: If the believers are as sure of their political truthwhich, if necessary, must be enforced with blood and violence-as the son of God was of his truth.

(Kelsen, 1920: 38$)^{69}$

Relativism connects Kelsen's conception of democracy with his epistemology, which, more than just a theory of knowledge, entails a comprehensive worldview (Kelsen, 1925: 370). Both the critical philosophy of Kant and relativistic democracy reject the assumption of absolute, transcendent, supra-human values and ideas. In the second edition of Vom Wesen und Wert der Demokratie, Kelsen adds a long footnote to the conclusion, supplying proof of this alleged nexus between politics, epistemology and Weltanschauung. He aims to demonstrate the purportedly inextricable link, in the history of philosophy and political ideas, between a metaphysical worldview and autocracy, on the one hand, and between empiricism, relativism and democracy, on the other hand. In classical thought, metaphysicians such as Plato and Heraclitus advocated an autocratic politics, whereas the Sophists, on par with their empiricist philosophies of nature, stood for democracy. In medieval thought, the metaphysical edifice of scholastics is inseparable from an autocratic construction of the political order. At the dawn of modern philosophy, in turn, while Spinoza, whose pantheism Kelsen sees as signalling a turn from metaphysics to the empirical knowledge of nature, is a democrat, the metaphysician Leibniz, with his concept of a pre-established, divinely inspired harmony, coherently stands for autocracy.

There are, to be sure, prominent members of the Western philosophical canon that clearly do not fit into Kelsen's somewhat crude, Manichaean 
scheme. Aristotle, for instance, was certainly a metaphysician, but his political thought cannot be defined uncontroversially as autocratic, while Hobbes, on the contrary, conciliated a rationalistic and mechanistic philosophy of nature with a theoretical vindication of absolute monarchy. In any case, however, the major point of controversy-and interest-in this historical-philosophical account is Kant's standing in the dichotomy. Kelsen discards the view that Kant's idealism is opposed to positivism. According to him, in characteristically neo-Kantian fashion, by shifting the focus from ontology to epistemology, from the nature of being to the conditions of possibility of its knowledge, '[t]ranscendental philosophy can only be correctly understood as a theory of experience' (Kelsen, 1929: 101, n. 45). ${ }^{70}$ If consistently thought through, this philosophy of knowledge would translate into a relativistic axiology and a democratic politics. However, in Kant's critical philosophy, there is no smooth continuity between theoretical philosophy and practical philosophy, the latter being still metaphysically oriented. For Kelsen, that is a foremost incongruence. How can one coherently bring absolute truth and absolute value back into the ethical and political spheres, after one had ruthlessly disposed of them in the realm of knowledge? How can one make a cogent system of human ethics and politics rest on absoluteand, thus, unknowable - assumptions? In Kelsen's view, the priority of form and function over substance in Kant's Critique of Pure Reason must have significant consequences for our understanding of society and politics. Indeed, Kelsen (ibid.) asks, was not Kant's insistence on the method, rather than on the object, of knowledge akin to 'a political attitude which replaces the question of the right content of the social order by the question of the method of formation of said order? ${ }^{71}$ Kelsenian democracy, hence, accorded itself the status of a coherent political complement to Kantian epistemology.

This affinity between the problems of knowledge and power, in general, and between (neo-)Kantian epistemology and democracy, in particular, is most clearly stated in 'Foundations of Democracy,' the only essay on democratic theory that Kelsen wrote in his American exile:

The main problem of political theory is the relationship between the subject and the object of domination; the main problem of epistemology is the relationship between the subject and the object of cognition. The process of domination is not so different from that of cognition by which the subject tries to be master of his object by bringing some order into the chaos of sensual perception.

(Kelsen, 1955: 15)

In both cases, there are two clear alternatives on how to conceive of the relationship between subject and object: autocracy or democracy, 
absolutism or relativism. First, Kelsen focuses on the process of cognition. To his mind, 'absolutism is the metaphysical view that there is an absolute reality, i.e., a reality that exists independently of human cognition,' whereas 'relativism...advocates the empirical doctrine that reality exists only within human cognition, and that, as the object of cognition, reality is relative to the knowing subject' (Kelsen, 1955: 16). Kant's epistemological priority of form and method over substance forces one to view 'the process of cognition as the creation of its object,' a process, therefore, where man appears as 'the creator of his world, a world which is constituted in and by his knowledge' (Kelsen, 1955: 17). Absolutism, on the contrary, claims to access a realm beyond the a priori limits of human understanding - an absolute reality, from which absolute truth, absolute value and, eventually, absolute authority can be derived.

The idea that man is the creator of his epistemological world, however, must be qualified. To begin with, this does not imply sheer arbitrariness. Man does not create the world of human knowledge like an omnipotent divinity. Knowledge is not the product of unbounded human volition, but of aprioristically limited human understanding, bound by 'the laws of rational cognition' (Kelsen, 1955: 18). These provide common ground for the human experience of natural and social reality, allowing it to be intersubjectively shared. Although a relativistic epistemology cannot guarantee the objective existence of the world beyond the limits of human cognition, it can nevertheless secure objectivity by conceiving all human beings, qua knowing subjects, as equals. In other words, rational cognition of reality is objective, and not a mere expression of subjective emotions, because the processes governing its formation are identical in each individual human mind. According to the Austrian thinker, this equality of men as knowing subjects, which is analogous to the formal equality of the participants in the democratic will-formation process, allows a relativistic epistemology to avoid two specific risks:

The one [risk] is a paradoxical solipsism; that is, the assumption that the ego as the subject of knowledge is the only existent reality... Such an assumption would involve a relativistic epistemology in a selfcontradiction. For if the ego is the only existent reality, it must be an absolute reality. Uncompromised solipsism, too, is philosophical absolutism. The other danger is a no less paradoxical pluralism. Since the world exists only in the knowledge of the subject according to this view, the ego is, so to speak, the center of his own world. If, however, the existence of many egos must be admitted, the consequence seems to be inevitable that there are as many worlds as there are knowing subjects. Philosophical relativism deliberately avoids solipsism as well as pluralism.

(Kelsen, 1955: 17) ${ }^{72}$ 
The formal equality of subjects under 'the laws of rational cognition' conciliates the relativity of knowledge with its objectivity. But what about democracy as political relativism? Does it face comparable perils? And if so, is it able to avoid them? Despite the close affinity he posits between the theories of politics and knowledge, Kelsen does not stretch the parallel so far as to consider a possible analogy between the intrinsic dangers of a relativistic epistemology and the inherent risks of relativistic democracy. In the following lines, we will pursue the analogy further from the point where Kelsen leaves it.

Political relativism, too, appears to involve the peril of relapsing into a form of solipsism. Kelsen's own distinction between a primordial natural freedom and political freedom proper unmistakably suggests such a danger. Natural freedom, even if it constitutes the deepest source of the call for democracy in the human soul, exhausts itself in a solipsistic negation of society. It represents, in Kelsen's (1955: 18) words, 'a reaction against [the] compulsion implied in any kind of social reality, the protest against a foreign will to which the own will should submit.' In the name of such freedom, anarchists and political nihilists have attacked both democracy and autocracy as forms of social authority, as epitomes of the domination of man over man. Relativistic democracy avoids such a peril, because it rests not on a purely negative natural freedom, which rebels against society, but on a positive freedom aiming at the establishment, in coordination with one's equal fellow citizens, of a certain social order. Democratic freedom, hence, 'must assume the meaning of a specific method of establishing order, of a specific type of government' (Kelsen, 1955: 19). Such conception of freedom in positive and explicitly intersubjective terms also avoids a contrary, arguably more dangerous expression of political solipsism, namely, that of the inflated ego that sees itself as the one and only lawmaker. Instead of demanding freedom from coercion, this 'exaggerated egoconsciousness' (Kelsen, 1955: 27) aims to impose its law upon a reality which, in the final analysis, is but a mere product of the ego's will. Just as, in the theory of knowledge, uncompromised solipsism reverts to philosophical absolutism - which Kelsen (1955: 26), quite tellingly, also renders as 'epistemological totalitarianism'-in the theory of politics, it turns into an overblown variant of autocracy, i.e. that of the totalitarian Egocrat. ${ }^{73}$

If relativistic democracy, like a coherent relativistic epistemology, successfully circumvents the dangers of solipsism, for the challenge of pluralism, there is, as far as I can see, no equally satisfying answer. Here, indeed, the analogy between the problems of knowledge and politics reaches to its limits. Contrary to a relativistic epistemology, political relativism cannot avoid the conclusion that there are, or, rather, that there may be, as many political worlds as there are political subjects. In the realm of politics, there is no equivalent to the intersubjectively shared 'laws of rational cognition.' Politics is above all about volition, not cognition. In politics, 
as in ethics, relativity cannot be reconciled with objectivity, and the full consequence of pluralism must be acknowledged. Just as axiological relativism leads to moral pluralism, so political relativism must conclude that there are several disparate, conflicting and perhaps even incommensurable political (world)views, and that individuals make ultimately arbitrary choices between them. Kelsen often emphasizes the rationalistic character of democracy, meaning by this its insistence on method and form rather than substance. From such peculiarly rationalistic perspective, it follows that, to remain true to itself, democracy cannot exclude its irrationalist enemies from the democratic processes of leadership selection and legislative will formation. The consequence, as we have seen earlier, is simple and clear, even if it might prove tragic: 'not to force democracy upon those who prefer another form of government, to remain aware in the struggle for one's own political ideal that the opponents, too, may be fighting for an ideal' (Kelsen, 1955: 39, n. 70). In this regard, the rise of totalitarian dictatorship in Germany, which affected Kelsen personally, did not prompt the author to move one inch in his theoretical stance after the Second World War.

From Kelsen's democratic thought emerges, in sum, a modest version of scientism, which eschews philosophical-historical teleology. Unlike Kant's (1991: 41-53) 'Idea for a Universal History with a Cosmopolitan Purpose,' Kelsen does not see the political events of human history, shaped as they are by the irrational forces of human volition, leading in whichever oblique way to a progressive, rational telos. If anything, Kelsen's short remarks on the history of philosophy and political ideas point towards an ever-recurring, irresolvable dualism, opposing absolutism and relativism, autocracy and democracy. In a move ironically more reminiscent of Plato (1888: 248/544c and ff.), whom he accused of being the intellectual ancestor of modern totalitarianism, than of the much-admired psychology of Freud, Kelsen (1955: 15, 26-27) adds that this dualistic 'typology of political and philosophical doctrines must finally result in a characterology' opposing the 'exaggerated egoconsciousness' of absolutism/autocracy to the relativistic-democratic type of personality, 'whose desire for freedom is modified by [the] feeling of equality.' Never will reason or history resolve the perpetual conflict of philosophical doctrines, political systems and psychological types, just as they cannot provide an answer to the eternal problem of justice (Kelsen, 1957: 1-24). And really existing democracies, too, cannot realize the primordial idea of freedom which lies at their root, but merely attempt to guarantee social peace by working out compromises between divergent and opposed material and ideal interests (Kelsen, 1929: 68; 1968g: 1687; 1968i: 1770).

Still, despite the limits of reason, which according to him constitute the conditions of possibility of both modern science and democracy, and moderate their respective ambitions, Kelsen hangs on to a concept of knowledge as truth-discovery. For him, there is humanly accessible 
knowledge of nature and society that is indeed pure knowledge, free from subjective opinion and belief. Kelsen's relativism does not take the radical post-modern step of conceiving science as just one more story about this world, among many others. He abandons grandiose hopes of omniscience and discards teleology - at least in the more restrained formulations of his commitment to science-but does not let go of science's monopoly on truth and knowledge. In the final analysis, the value of science can only be affirmed, if it is strictly severed from opinion and belief, if it can expose these as illusion or ideology. The purity of the pure theory of law rests, ultimately, on this sharp distinction between science and ideology. The problem is, however, that the distinction itself cannot be justified on rational, scientific grounds. As we found out when we delved into the intricate issue of the Basic Norm, the hypothetical foundation that grounds juristic knowledge is, according to Kelsen himself, the sheer product of an "act of will," arbitrary, from a normative perspective, as will always is. The final, transcendental point of imputation of a science of positive norms seems, thus, to perform a characteristically ideological function, in that it obscures and prevents one from considering, depending on the perspective, the actual empirical or the moral-transcendent foundations of law. In this sense, Kelsen's Grundnorm comes close to what Kant (1998: 385) refers to as a "transcendental illusion, which...holds out to us the semblance of extending the pure understanding. ${ }^{, 74}$ The theory of law cannot fully elucidate the origins of law, and of law's validity, without relinquishing its dream of pure legal immanence, without acknowledging the transcendent impurity that the transcendental method obsessively seeks to repress.

Philosophers of rather diverse leanings have conceived precisely the idea of pure knowledge as the intrinsically mythical aspect of the Enlightenment, thus challenging the dualism of truth and myth, science and ideology (Serres, 1974; Horkheimer and Adorno, 2000). Despite the sceptical, relativistic declination of his rationalism, this would go more than one step too far for Kelsen. However, to construe the value of science from its grasp on truth and knowledge, while at the same time denying it the capacity to discern the norms of rightful human conduct as well as the audacity to even pose, let alone answer, the question of the destiny of humankind appears to invite the nihilistic reduction of knowledge to an instrument compatible with any given purpose, as Strauss (1953: 4, n. 2) points out, with explicit reference to Kelsen, in his critique of modern social science. Kelsen's conceptions of science and democracy walk hand in hand. Democracy, indeed, is the only 'social order under whose protection the search for truth can prosper' (Kelsen, 1957: 24), and only a widespread scientific-relativistic mentality will consolidate democracy as the appropriate method for creating social order. Yet, science, even if it can hardly prosper, might still survive in an autocracy, to the extent that the truths it discovers, and the uses these are put to, remain harmless to 
the autocratic elite. Democracy, on the contrary, cannot survive a majority of political absolutists united (perhaps only) in the will to destroy it.

\section{Indeterminacy and the Impasses of Relativism: Concluding Observations}

Kelsen's relativistic case for democracy leads to fruitful pluralistic consequences, which testify to a penetrating sociological insight that one would perhaps not have expected from a thinker who is often-and not entirely without reason-depicted as an arid legal formalist. His rejection of a mythical, pre-existing, unitary popular will as a metapolitical illusion made an uncompromising break with traditional state theoryand not just with the state theory of nineteenth-century German public law, but more generally with the early modern paradigm of sovereignty. The process of forming the collective will of the democratic social order, which is not a real will but a normative one, required the acknowledgement of the real sociological diversity of the people, expressed by the spontaneous emergence of a plurality of political parties. These, which modern political thought, under the influence of the monolithic theories of Hobbes and Rousseau, had largely conflated with factionalism and deemed irreconcilable with the common weal, acquired in Kelsen's democratic theory a positive, and even irreplaceable, role. ${ }^{75}$

The defence of party pluralism on essentially democratic rather than purely liberal grounds - even if pluralism also leads to a vindication of certain, though not all, characteristically liberal values and institutionsis certainly no minor achievement. However, Kelsen's relativism is incapable, and admittedly so, of providing a robust defence of democratic pluralism against autocratic encroachment and dissolution. The reason for this lies in his, however restrained, scientistic concept of relativism. Kelsen takes his idea of relativism from the transcendental epistemological notion that all accessible reality is relative to, and constituted by, the knowing subject. In applying it to democratic theory, though, he pushes the analogy between epistemology and politics, to formulate it paradoxically, both too far and not far enough. Too far in the sense that he repeatedly suggests that a scientific theory of knowledge can be taken to supply modern democracy with definitive Weltanschaunng-wise foundations in a post-metaphysical age. Not too far, in a different, double sense. First, by failing to grasp that it is not so much relativism, with its rejection of an absolute reality, but rather fallibilism, which leads to a pluralistic understanding of democracy. Indeed, rigorously speaking, it is not the circumstance that reality is relative to oneself as knowing subject, and therefore knowledge of an absolute value impossible, but more precisely one's liability to err-which is one possible though by no means necessary consequence of said relativity and impossibility - that leads one to the pluralistic realization that 'the opposite opinion to one's 
own must also be deemed possible' (Kelsen, 1920: 36).$^{76}$ Kelsen, however, was more interested in vindicating the possibility of objective knowledge against the danger of what he saw as a 'paradoxical pluralism' in epistemology than in probing deeper into the pluralistic nature of modern democracy. Second, as we have shown earlier, by not pushing the analogy between the theories of knowledge and politics to its ultimate consequences, Kelsen fails to discern its limits. The careful elucidation of such limits would have been instrumental to Kelsen's own goal — chimerical and self-defeating, in our view - of drawing a strict boundary between science and politics/ideology. However, and most importantly, it could have made him realize that the pluralism of modern democracy is more radical than the relativistic epistemology he takes to be the worldview undergirding it would allow for.

Claude Lefort's (1988: 14-20) conception of the experience of indeterminacy inaugurated by the modern democratic revolution provides a helpful corrective to the shortcomings of Kelsen's understanding of pluralist democracy. According to Lefort (1988: 226), the democratic break with the monarchical order and its theologico-political underpinnings-a break whose importance at the symbolic level is at least as significant as at a more strictly defined political dimension - has created a social and political vacuum that turned power into an 'empty place...without any positive determination.' A vacuum that cannot be filled, an 'empty place' that cannot be permanently occupied, where nothing remains unchallenged, because modern democratic society experiences itself as internally divided, as a society without a cohesive body (Lefort, 1988: 34). The closest Kelsen came to such a notion of indeterminacy was in his 1927 address on democracy to the congress of the German Sociological Association. Questioning the 'hunger for reality of many sociologists,' and providing nuance to the strict dualism of ideology and reality, the Austrian jurist averred:

For what is assumed to be reality in this contrast to ideology often turns out to be, on closer examination, ideology again. Sociological analysis has to identify several layers of ideologies in order to find the core real fact it seeks. This puts sociology in a scientific situation that some find so unsatisfactory only because they think they are cracking a nut, when in truth they are merely peeling an onion. In view of the hunger for reality of many sociologists, the question is perhaps in order, whether it would be so surprising, if one were to realise that in the social realm there is nothing but ideologies...

(Kelsen, 1968i: 1745) $)^{77}$

If, however, there is nothing to society but different types and layers of ideology, and given that the law, according to Kelsen, belongs to the social realm rather than to the domain of nature with its causal laws, how is 
it possible and what is the point of studying law scientifically? Why is law an ideology worth going along with? And how can its scientific treatment emerge nevertheless as a critique of ideology? What justifies the ferocity with which Kelsen sought to establish and defend its perimeters as a normative scientific discipline? Despite the unquestionable intellectual sophistication of Kelsen's work, in my view it does not provide convincing answers to these questions. Ultimately, his whole enterprise appears to rest upon an arbitrary choice for science, for the science of law, for a science without reality. When it comes to democratic theory, that choice leads him to fill the vacuum of modern indeterminacy with a relativistic theory of knowledge, thus missing the full implications of a pluralistic conception of democracy. Had Kelsen grasped these implications, he might have found the philosophical resources to expose and combat, as inherently antidemocratic, any attempt to arrive at a definitive closure of the people, to re-enact the metaphor of the body, of the 'People-as-One' (Lefort, 1988: 13), instead of succumbing — as he did - to resignation in the name of logical consistency.

\section{Notes}

1 See the previous chapter on Schmitt's critique of Kelsen in Political Theology, as well as Voegelin (1936: ch. 6) and Kaufmann (1921).

2 In light of these words, it is strange to see Carrino (1995: 186), in an otherwise very rich comparative study, refer to Weber straightforwardly as a neoKantian sociologist and forget to underscore the much stronger influence that Kantian and neo-Kantian philosophy exerted upon Kelsen.

3 Kant, of course, could be easily claimed as the inspiration for the idea of duty.

4 For biographical sketches of the circle around Hans Kelsen, see Walter, Jabloner and Zeleny (2008).

5 'Der Gegensatz von Sein und Sollen ist ein formal-logischer und insolange man sich in den Grenzen formal-logischer Betrachtung hält, führt kein Weg von dem einen zum andern, stehen beide Welten durch eine unüberbrückbare Kluft getrennt einander gegenüber.' As we saw in the previous chapter, the image of the 'two worlds' of Is and Ought was also used by Schmitt in his own Habilitationsschrift, Der Wert des Staates und die Bedeutung des Einzelnen (1914), thus showing that the two antipodes of Weimar jurisprudence had not yet consolidated their antagonistic positions in these early works. On closer inspection, in any case, one would have to conclude that Schmitt was further away from such consolidation than Kelsen.

6 See the supplementary notes in Kelsen (1992: 132-134) for further elucidation on the translation of this term.

7 For an early attempt to historicize Kelsen's legal theory, placing it in the context of imperial Austro-Hungarian constitutional debates since 1848, see Voegelin (1936: 55-101). For an account that seeks to contextualize Kelsen's legal theory from a sociology of knowledge perspective, by taking into account especially the author's social and religious origins, see Paz (2015) - a useful essay even if it occasionally verges on the hagiographic.

8 In actual fact, Husserl does not "ismify" logic in the Investigations, even if this work has been received as the classical critique of psychologism from 
a "logicist" point of view. The concept of logicism (Logismus) was coined by one of the founders of experimental psychology, Wilhelm Wundt (whom Husserl (1970: 51) charges of incurring in 'basic errors in logic'), as a critical description of Husserl's anti-psychological stance. Husserl's (1970: 1) explicit aim was to achieve 'a philosophical clarification of pure mathematics,' and later he refuted the idea that the Investigations would have represented a form of logicism. Since Kelsen (1923a: 4, n. 4; 5, n. 1) refers to Wundt's Logic and Ethics, it seems likely that he was led to the notion of a general contrast between logicism and psychologism by Wundt's reply to Husserl rather than directly by the founder of phenomenology. I thank Timo Miettinen for calling my attention to this point. For a theoretical critique of Kelsen from the perspective of Husserl's phenomenology, see Minkkinen (2005: 243-247). On the philosophical controversies over psychologism at the turn from the nineteenth to the twentieth century, see Gabriel (2016).

9 Voegelin (2003), in an excellent article first published in the Festschrift for Hans Kelsen on the occasion of his 50th birthday, argues forcefully that the reductionist neo-Kantian approach does extreme violence to the Kantian philosophical project in general, and to Kant's concept of Sollen in particular. Indeed, one does not need to follow Voegelin - who, eventually, turns not just against the neo-Kantians, but also against Kant himself-all the way to concede that his interpretation of the Kantian Ought is philologically more precise and perhaps "spiritually" closer to the original than Kelsen's neo-Kantian reading. For an aggressive and rather crude critique of both neo-Kantianism and Kelsen, elaborated for the purposes of an appraisal of Voegelin's intellectual formation, see Szakolczai (2011: 137-151).

10 The Heidelberg philosopher lays out this distinction in two main works, which underwent extensive revisions in subsequent editions: Die Grenzen der naturwissenschaftlichen Begriffsbildung (1896) and Kulturwissenschaft und Naturwissenschaft (1899). For Rickert, the quintessential, individualizing and value-relating, cultural science was history.

11 Emphasis in the original: 'Realität und Idealität können sich niemals in einem Begriffe verbinden oder von demselben Standpunkt einer Wissenschaft aus erfaßt werden, da sich die Realität nur unter einem wesentlich anderen Gesichtspunkt der Betrachtung ergibt als die Idealität, da ein Inhalt nur entweder in der Erkenntnisform des Seins oder in der des Sollens, in dem ersten Falle als Wirklichkeit, im zweiten als Wert sich darstellt. Auf dem Wege ganz verschiedener Erkenntnisrichtungen wird das Gegebene zur Wirklichkeit oder zum Werte.'

12 Within the Marburg school, the influence of Hermann Cohen's philosophy on the Kelsenian project has been especially emphasized in the secondary literature (Holzhey, 1986; Paulson, 1992; Edel, 1998; Carrino, 2011). Considerably less attention has been paid to the relationship between Kelsen's work and the philosophy of Ernst Cassirer, but see lately Favuzzi (2019). For a juxtaposition of the two main schools of neo-Kantianism, see Krijnen and Noras (2012).

13 'Der methodologische Gegensatz zwischen Soziologie und Jurisprudenz, von dem die folgenden Erörterungen ausgehen, ist der zwischen Sein und Sollen.'

14 It seems fair to conclude that, especially before and during the First War, Kelsen was anxious about the prospect of a "sociological imperialism" in jurisprudence.

15 'Denn die Philosophie kann die „Wirklichkeit“ nicht unter dem Gesichtspunkte ihres absoluten Wertgehaltes betrachten, wenn die Wirklichkeit selbst nur das Ergebnis einer absolut wertfreien Betrachtung ist.' 
16 'Daß die juristische Theorie, die sich recht abseits von philosophischen Spekulationen, insbesondere methodologischer und erkenntnistheoretischer Natur entwickelt hat, und die bisher so gut wie gar nicht von dem kritischen Methodendualismus berührt wurde, bei dem Problem der Positivität des Rechts durchweg den schweren Fehler beging, die Geltung der Rechtsordnung, d. h. das rechtliche Sollen, auf irgendeine Seinstatsache, einen realen Vorgang zurückzuführen, ist nicht allzu befremdlich. Weniger verständlich ist es, wenn ein Philosoph, der als ein Vertreter des kritischen Methodendualismus auftritt und gerade als solcher berufen wäre, die Jurisprudenz aus mancher Wirrsal zu befreien, sie in einem ihrer verhängnisvollsten Irrtümer bestärkt, ja sogar den überaus erfreulichen Ansätzen, die speziell in dieser Richtung zu konstatieren waren, mit dem ganzen Gewicht seiner philosophischen Autorität entgegentritt.' Emphasis in the original. For an overview of Lask's philosophy of law, see Hobe (1973).

17 On Schmitt's peculiar Hegelian-Catholic argument in Der Wert des Staates und die Bedeutung des Einzelnen (1914), see our analysis in the previous chapter. For a helpful overview of Radbruch's legal-philosophical project, see Ward (1992).

18 Even if, one must add, it never succumbed to a crude form of naturalism.

19 'Auch die bedeutendste soziologische Leistung, die seit Simmels ,Soziologie“ erschienen ist, Max Webers geistvolle Untersuchungen über „Wirtschaft und Gesellschaft,“ bestätigen, daß alle Bemühungen, das Wesen des Staates auf außerjuristischem, speziell soziologischem Wege zu bestimmen, immer wieder auf eine mehr oder weniger versteckte Identifikation des gesuchten Begriffes mit dem Begriff der Rechtsordnung hinauslaufen.'

20 Emphasis elided from "science," but retained on "of reality."

21 'Aus der hier durchgeführten kritischen Analyse der relevanten Grundbegriffe der „verstehenden Soziologie“ geht hervor, daß Weber sich nicht hätte vorsichtig - die Frage nach dem Verhältnis von Staat und Recht offen lassend-darauf beschränken müssen, zu sagen: für den Staat ist eine Verwaltungs- und Rechtsordnung charakteristisch, sondern der ganze Aufbau des Weberschen Begriffssystems drängt geradezu zu der Erkenntnis: der Staat ist eine Rechtsordnung. Damit ist die Staatssoziologie als Rechtslehre enthüllt. Daran kann der stete Bezug auf die Faktizität...nichts ändern. Die primäre, wahrhaft grundlegende Bedeutung des normativen Rechtsbegriffes ist gerade in der Methode der ,verstehenden“ Soziologie unverlierbar festgehalten, denn diese ist auf den Sinngehalt des Handelns gerichtet, und der stellt sich dort, wo die Untersuchung auf den Staat zielt, immer wieder nur als der Gedanke des Rechtes als einer Zwangsnorm heraus. In diesen immanenten Sinn muß sich die verstehende Soziologie versenken, den spezifischen Standpunkt der Rechtsbetrachtung muß sie sich zu eigen machen, soll sie die Handlungen deuten können. In diesem immanenten spezifisch juristischen Sinne liegt alles beschlossen, was diese Soziologie über das Wesen des Staates aussagen kann; es ist nicht um ein Wörtchen mehr, als die normative Rechtstheorie lehrt.'

22 Emphasis mine. This would probably not have gone unnoticed, if Kelsen had bothered to check how these concepts are developed and deployed in Weber's sociology of domination, which attempts to discern, not formal validity, but rather an actual belief in legitimacy shared by the relevant audience towards which the claim to legitimacy is addressed (Weber, 1978: 213, 248).

23 In this regard, more than Cohen, Kelsen seems to follow Ernst Cassirer's Substanzbegriff und Funktionsbegriff (1910), arguably 'the most sophisticated work on the philosophy of science in all neo-Kantianism' (Beiser, 2013: 123), 
which the Austrian jurist quotes multiple times in a 1921 article on the relationship between state and law as viewed from the perspective of critical epistemology (Kelsen, 1968c: 102-107). Cassirer's main argument is that 'theory cannot be verified or falsified by its encounter with bare facts, which do not exist, but only by its consequences and coherence with other constructions' (Beiser, 2013: 123).

24 The naïve evolutionism of Kelsen's Society and Nature (1946), for instance, comes across today as almost embarrassing.

25 This has been noted by Weber and Kelsen scholars alike. See, respectively, Tyrell (1994) and García-Salmones Rovira (2011: 47-50).

26 Emphasis added.

27 On the methodological problems afflicting Weber's conception of legitimacy, see Chapter 1 in this volume. For other comparative takes on Weber and Kelsen, which at least in part go beyond the epistemological issues upon which we have focused here, see Lübbe (1991: 25-65) and Bobbio (1992: 159-177), as well as the more recent essays gathered in Bryan, Langford and McGarry (2016).

28 See the introduction to this volume for an overview of these struggles.

29 'Ich weiß nicht, wie die Theologie diese Schwierigkeit löst; wenn es ihr nicht gelingen sollte, hat sie immerhin als Rechtfertigung die metalogische und transrationale Natur der letzten Begriffe für sich. Diese Rechtfertigung fehlt aber der Rechtstheorie für ihre Konstruktionen und darum muß sie das unlogische Monstrum eines staatlichen Unrechts um jeden Preis vermeiden.'

30 The publication year of the issue of the journal Logos where the article first appeared is $1922 / 1923$. The essay contains no reference, explicit or implicit, to Schmitt.

31 Emphasis elided: 'Von einem erkenntniskritischen Standpunkt kommt es vor allem darauf an, die theologische Methode in den Geisteswissenschaften und speziell in den Sozialwissenschaften zu überwinden, den System-Dualismus $\mathrm{zu}$ beseitigen. Gerade in dieser Richtung aber leistet eine unschätzbare Vorarbeit die psychologische Analyse Freuds, indem sie aufs wirksamste die mit der ganzen Magie jahrhundertealter Worte ausgerüsteten Hypostasierungen Gottes, der Gesellschaft und des Staates in ihre individual-psychologischen Elementen auflöst.'

32 This excerpt shows that Kelsen tolerates fictive personalization as an intellectual means to conceive the state. The fiction of personification is not per se the problem, but rather the hypostatic dualist theories it succumbs to in less sophisticated minds. Concerning fiction as a powerful tool of the intellect, the author drew on Hans Vaihinger's The Philosophy of "As if" (1911) (Kelsen, 1919). For a useful juxtaposition of the analogies Kelsen establishes between theology and the traditional theory of the state, see the table in Baume (2009: 374).

33 In any case, Kelsen's epistemic anarchism should not be likened to the much more radical epistemological anarchism of Paul Feyerabend's Against Method (1975). Nothing would be more irreconcilable with Kelsen's quest for legal-scientific purity than an "anything goes" attitude towards methodologies, and it is not difficult to imagine that Kelsen would have joined those who considered Feyerabend an enemy of science.

34 Yet, this is not to say that epistemic anarchism has no ethical-political consequences at all. Quite on the contrary, according to Kelsen (1973: 81), by equating the concept of the state with that of the man-made, historically contingent and thus ever-alterable legal order, epistemic anarchism bears a progressive, reform-oriented impulse. 
35 Emphasis in the original. In this extract, the crucial opposition between substance and function is accompanied by a footnote referring to the works of the legal theorist Fritz Sander, 'the enfant terrible of the Vienna school' (Paulson, 1992: 322, n. 40). However, the original source for this oppositionsee n. 23 above - is Cassirer's philosophy of science. Secondary literature on Sander is rather scarce, but see lately Tannous (2018) for a book-length treatment of the debate between Kelsen and Sander.

36 'Die Antwort auf die Frage: warum sollen die Befehle des Fürsten, die Gesetze des Staates (wie man zu sagen pflegt) befolgt werden, warum sind die Normen, kurz dasjenige, worauf die Geltung der konkreten Rechtsordnung zurückzuführen ist, kann wiederum nur ein Sollen sein: die oberste, nicht weiter abgeleitete Norm: du sollst den Befehlen des Fürsten oder den Gesetzen des Staates gehorchen. Dieser Satz-der „Rechtssatz“ in einer gesteigerten Bedeutung des Wortes_-ist die Voraussetzung_die einzige Voraussetzung jeder konkreten Rechtsordnung.'

37 Emphasis in the original. On the different formulations of the Grundnorm in Kelsen's work, see Paulson (1993).

38 Kelsen's own references to Spinoza are sparse. In addition to the one in Das Problem der Souveränität that Aurélio (2015: 49) mentions, where the philosopher from Amsterdam 'is loosely associated with the "monism" that Hegel would later postulate,' in the second edition of Vom Wesen und Wert der Demokratie he appears, in rather more positive light, as a thinker whose pantheism, understood as a turn from metaphysics to the empirical knowledge of nature, went hand in hand with his democratic thought, in shrill contrast to the autocratic politics of the metaphysician Leibniz (Kelsen, 1929: 101, n. 45). Still, it is very doubtful that Kelsen would accept having his pure theory of law likened to Spinozian metaphysics, even if his contrast between the substantive-static Basic Norm of morality and the formal-dynamic Basic Norm of law bears striking resemblances to Spinoza's concept of God as dynamic Natura naturans, not static Natura naturata. One could suggest, in light of this parallel, that the law was Kelsen's self-creating, ever-growing and changing God. Finally, in this regard, it should be noted, as Aurélio (2015: 250-252) keenly points out, that Hermann Cohen, Kelsen's chief neo-Kantian influence, was a fierce critic of Spinoza's, whom he accused of scholasticism and power-serving philosophizing.

39 The state-bounded perspective, in addition, is predominant in the treatment of the theory of the Basic Norm offered by the Introduction to the Problems of Legal Theory, though Kelsen (1992: 62) notes in passing that '[i]f one takes the primacy of international law as one's point of departure, then the problem of the basic norm shifts its focus from state legal systems and becomes the problem of the ultimate basis of the validity of a comprehensive legal system [umfassenden Total-Rechtsordnung] encompassing all state legal systems.'

40 Emphasis in the original: '[Kelsens] Theorie wird aber verständlich, wenn man sie als letzten Ausläufer der vorerwähnten echten Theorie des bürgerlichen Rechtsstaates ansieht, welche aus dem Staat eine Rechtsordnung zu machen suchte und darin das Wesen des Rechtsstaates erblickte. In seiner großen Epoche, im 17. und 18. Jahrhundert, fand das Bürgertum die Kraft zu einem wirklichen System, nämlich zu dem individualistischen Vernunft- und Naturrecht, und bildete aus Begriffen wie Privateigentum und persönliche Freiheit in sich selbst geltende Normen, welche vor und über jedem politischen Sein gelten, weil sie richtig und vernünftig sind und daher ohne Rücksicht auf die seinsmäßige, d. h. positiv-rechtliche Wirklichkeit ein echtes Sollen enthalten... Bei Kelsen dagegen gelten nur positive Normen, d. h. solche, welche 
wirklich gelten; sie gelten nicht, weil sie richtigerweise gelten sollen, sondern ohne Rücksicht auf Qualitäten wie Vernünftigkeit, Gerechtigkeit usw. und nur deshalb, weil sie positiv sind. Hier hört plötzlich das Sollen auf und bricht die Normativität ab; statt ihrer erscheint die Tautologie einer rohen Tatsächlichkeit: etwas gilt, wenn es gilt und weil es gilt. Das ist „Positivismus.“”

41 Emphasis mine.

42 Emphasis in the original.

43 Emphasis Kelsen's: 'Die von der Grundnorm ermächtigte Autorität kann dann ihrerseits wieder, sei es für den ganzen Bereich ihrer Zuständigkeit, sei es nur für einen Teilbereich, eine andere Autorität delegieren; so etwa die Eltern für das Gebiet der Erziehung der Kinder einen Lehrer; und diese Delegation kann wieder fortgesetzt bzw. weitergegeben werden. Die Einheit des dynamischen Systems ist die Einheit eines Delegationszusammenhanges.'

44 For the author's early critique of revolutionary socialism, see Kelsen (1923b). On the context and genesis of Vom Wesen und Wert der Demokratie, see Lagi's (2007) helpful intellectual-historical study.

45 Emphasis elided.

46 Emphasis Kelsen's: 'Er ist ein Mensch wie ich, wir sind gleich! Wo ist also sein Recht, mich zu beherrschen?'

47 On Rousseau and democratic legitimacy, see the introduction to this volume.

48 Emphasis in the original: 'Die ungeheure, gar nicht überschätzbare Bedeutung, die gerade dem Freiheitsgedanken in der politischen Ideologie zukommt, ist nur erklärlich, soferne er aus einer letzten Quelle der menschlichen Seele, aus eben jenem staatsfeindlichen Urinstinkt entspringt, der das Individuum gegen die Gesellschaft stellt. Und doch wird in einer fast rätselhaften Selbsttäuschung dieser Freiheitsgedanke zum bloßen Ausdruck für eine bestimmte Stellung des Individuums in der Gesellschaft. Aus der Freiheit der Anarchie wird die Freiheit der Demokratie.'

49 '[L]a volonté ne se représente point: elle est la même ou elle est autre; il n’y a point de milieu.'

50 For a very recent take on how Kelsen veers towards Rousseau and then parts ways with the Genevan philosopher, see Baume (2019).

51 Emphasis Kelsen's: 'Weil sie [die Demokratie] den politischen Willen jedermanns gleich einschätzt, muß sie auch jeden politischen Glauben, jede politische Meinung, deren Ausdruck ja nur der politische Wille ist, gleichermaßen achten. Auch die gegenteilige Meinung muß man für möglich halten, wenn man auf die Erkenntnis eines absoluten Wertes verzichtet. Der Relativismus ist daher die Weltanschauung, die der demokratische Gedanke voraussetzt.'

52 'Die Beamten sind Diener der Gemeinschaft, nicht einer Partei.'

53 On Triepel, see Poscher (2000).

54 "Wenn der „,irdische Gott" von seinem Throne stürzt und das Reich der objektiven Vernunft und Sittlichkeit zu einem „magnum latrocinium“ wird, dann schlachten die Parteien den mächtigen Leviathan und schneiden sich aus seinem Leibe jede ihr Stück Fleisch heraus.'

55 Emphasis in the original: 'Die Demokratie ist notwendig und unvermeidlich ein Parteienstaat.'

56 Emphasis elided.

57 On the relationship between conceiving representation in terms of descriptive exactness and the defence of PR electoral systems, see Pitkin's (1967: 60 and ff.) remarkable study, which nonetheless fails to mention Kelsen in this connection, even if, albeit briefly, it references the Austrian jurist's view of representation as delegation of authority in its treatment of formalistic 
conceptions of representation (Pitkin, 1967: 42, n. 13). For a classical study, which rather simplistically blames proportional representation for the collapse of Weimar democracy, see Hermens (1941).

58 Emphasis elided: 'Parlamentarismus ist: Bildung des maßgeblichen staatlichen Willens durch ein vom Volke auf Grund des allgemeinen und gleichen Wahlrechtes, also demokratisch, gewähltes Kollegialorgan nach dem Mehrheitsprinzipe.'

59 Emphasis in the original.

60 Emphasis Kelsen's.

61 These passages from the concluding section of the 1925 brochure on the problem of parliamentarism constitute, to the best of my knowledge, the first instance of a critical engagement with Schmitt on the part of Kelsen.

62 Emphasis in the original: 'Die verfassungsmäßige Verankerung der politischen Parteien schafft auch die Möglichkeit, die Gemeinschaftswillensbildung innerhalb dieser Sphäre zu demokratisieren.'

63 For an insightful analysis of the controversy between Schmitt and Kelsen on the guardian of the constitution, see Dyzenhaus (1997: 102-160). This is a debate that we shall not explore further here, because it would deviate us slightly from our emphasis on relativism and pluralism as the chief elements of Kelsen's democratic theory, but nevertheless it should be stated that the positions of both authors, in that debate also, tie in with their fundamental philosophical and ideological presuppositions.

64 'Sie [die Demokratie] ist diejenige Staatsform, die sich am wenigsten gegen ihre Gegner wehrt. Es scheint ihr tragisches Schicksal zu sein, daß sie auch ihren ärgsten Feind an ihrer eigenen Brust nähren muß. Bleibt sie sich selbst treu, muß sie auch eine auf Vernichtung der Demokratie gerichtete Bewegung dulden, muß sie ihr wie jeder anderen politischen Ueberzeugung [sic] die gleiche Entwicklungsmöglichkeit gewähren... [W]er für die Demokratie ist, darf sich nicht in den verhängnisvollen Widerspruch verstricken lassen und zur Diktatur greifen, um die Demokratie zu retten.'

65 Emphasis Kelsen's: 'Wenn ich mich für die Demokratie entscheide, geschieht es ausschließlich...aus der Beziehung der demokratischen Staatsform zu einer relativistischen Weltanschauung.'

66 'So steigen hier doch, trotz des anfänglichen Programms, die „,rein formalen“ Begriffe ,zur Bedeutung eines absoluten Ideals“ auf! Und es ist wieder derselbe geschichtsphilosophische Hafen der Fortschrittsmetaphysik, die die reinen „Begriffe“ zu metaphysischen Potenzen heraufschraubt, die wir bereits kennen.' Schmitt's politico-theological verdict did not differ substantially from this, and he quoted Kaufmann's critique of neo-Kantian legal philosophy approvingly, even if later on he would work to have both Kelsen and Kaufmann expelled from their university positions because of their Jewish origins. For an excellent exposition and critique of Kelsen's internationalist position, see Koskenniemi (2001: 238-249). Bernstorff (2010) has authored a book-length study of Kelsen's theory of international law and GarcíaSalmones Rovira (2013) offers a helpful, holistic overview of the positivist international law project.

67 'Als unendliche Aufgabe aber muß solcher Weltstaat als Weltorganisation allem politischen Streben gesetzt sein.'

68 Emphasis in the original: 'Das bekannte Argument: auf die heutige Menschheit als Einheit angewendet, müsse das Majoritätsprinzip zu absurden Ergebnissen führen, trifft nicht so sehr das Prinzip als solches, als vielmehr nur seine Überspannung bei zu weitgehender Zentralisation.' 
69 'Vielleicht wird man, werden die Gläubigen, die politisch Gläubigen einwenden, daß gerade dieses Beispiel eher gegen als für die Demokratie spreche. Und diesen Einwand muß man gelten lassen; freilich nur unter einer Bedingung: Wenn die Gläubigen ihrer politischen Wahrheit, die, wenn nötig, auch mit blutiger Gewalt durchgesetzt werden muß, so gewiß sind, wie - der Sohn Gottes.'

70 'Die Transzendentalphilosophie kann nur als Theorie der Erfahrung richtig verstanden werden.'

71 Emphasis Kelsen's: 'Drängt sich da nicht die Parallele zu einer politischen Einstellung auf, die an Stelle der Frage nach dem richtigen Inhalt der sozialen Ordnung die Frage nach dem Weg, nach der Methode der Erzeugung dieser Ordnung stellt?'

72 Emphasis mine.

73 The term "Egocrat" was coined by Aleksandr Solzhenitsyn, as a reference to Stalin, in The Gulag Archipelago (1973), first published in the year of Kelsen's death. Subsequently, Lefort (1994) developed the concept in his critique of totalitarianism. Furthermore, it should be noted that in Kelsen's (1948: 1-2) critical analysis of the Soviet system, the author charges Bolshevism of falling precisely into the dual trap of political solipsism as I interpret it here, that is, of embracing anarchism in theory and totalitarianism in practice.

74 Emphasis in the original.

75 On the conflation of party and faction in modern political philosophy-with the notable exception of Burke, who nevertheless lacked a theory to back up his appreciation of parties-see Sartori (2005: 3-12).

76 Emphasis elided throughout. See above, p. 147, n. 51, for the complete excerpt where this citation is taken from.

77 Emphasis in the original: 'Denn was man in diesem Gegensatze der Ideologie gegenüber als Realität voraussetzt, stellt sich bei näherer Untersuchung häufig selbst wieder als eine Ideologie heraus; so daß die soziologische Analyse mehrere Schichten von Ideologien konstatieren muß, um sich bei ihrem Forschen nach dem als Kern gesuchten realen Tatbestand in einer wissenschaftlichen Situation findet, die von manchen nur darum als so unbefriedigend empfunden wird, weil sie glauben, eine Nuß zu knacken, wo sie in Wahrheit nur eine Zwiebel entschälen. Angesichts des Realitätshungers vieler Soziologen ist vielleicht die Frage am Platze, ob es denn gar so verwunderlich wäre, wenn man feststellen müßte, daß es im Bereich des Sozialen eben nichts als Ideologien gibt...'

\section{References}

Aurélio, D. P. (2009). 'O que representam os representantes do povo', in D. P. Aurélio (ed.), Representação Política: Textos Clássicos, Lisboa: Livros Horizonte, pp. 9-51.

Aurélio, D. P. (2015). 'Spinoza, Kelsen and the Nature of the Legal Norm,' in A. S. Campos (ed.), Spinoza and Law, London: Routledge, pp. 249-268.

Baume, S. (2009). 'On Political Theology: A Controversy between Hans Kelsen and Carl Schmitt,' History of European Ideas, Vol. 35, No. 3, pp. 369-381.

Baume, S. (2012). Hans Kelsen and the Case for Democracy, trans. J. Zvesper, Colchester: ECPR Press.

Baume, S. (2019). 'Hans Kelsen and the Requirement of Self-Determination: How the Austrian Jurist Takes Inspiration from Rousseau and How He Emancipates Himself from the Swiss Philosopher,' in P. Langford, I. Bryan and J. 
McGarry (eds), Hans Kelsen and the Natural Law Tradition, Leiden: Brill, pp. $188-214$.

Beiser, F. C. (2013). 'Weimar Philosophy and the Fate of Neo-Kantianism,' in P. E. Gordon and J. P. McCormick (eds), Weimar Thought: A Contested Legacy, Princeton: Princeton University Press, pp. 115-132.

Berman, S. (1997). 'Civil Society and the Collapse of the Weimar Republic,' World Politics, Vol. 49, No. 3, pp. 401-429.

Bernstorff, J. v. (2010). The Public International Law Theory of Hans Kelsen: Believing in Universal Law, trans. T. Dunlap, Cambridge: Cambridge University Press.

Bobbio, N. (1992). Diritto e Potere: Saggi su Kelsen, Naples: ESI.

Bruun, H. H. (2007). Science, Values and Politics in Max Weber's Methodology, new ex. ed., Aldershot: Ashgate.

Bryan, I., P. Langford and J. McGarry (eds) (2016). The Reconstruction of the Juridico-Political: Affinity and Divergence in Hans Kelsen and Max Weber, Abingdon: Routledge.

Carrino, A. (1995). 'Max Weber et Hans Kelsen,' in C.-M. Herrera (ed.), Le droit, le politique autour de Max Weber, Hans Kelsen, Carl Schmitt, Paris: L'Harmattan, pp. 185-203.

Carrino, A. (2011). Das Recht zwischen Reinheit und Realität. Hermann Cohen und die philosophischen Grundlagen der Rechtslehre Kelsens, Baden-Baden: Nomos.

Dewalque, A. (2016). 'Addressing the Specificity of Social Concepts: Rickert, Weber, and the Dual Contrast Theory,' in P. Langford, I. Bryan and J. McGarry (eds), The Foundation of the Juridico-Political: Concept Formation in Hans Kelsen and Max Weber, Abingdon: Routledge, pp. 77-96.

Dreier, H. (1986). Rechtslehre, Staatssoziologie und Demokratietheorie bei Hans Kelsen, Baden-Baden: Nomos.

Dyzenhaus, D. (1997). Legality and Legitimacy: Carl Schmitt, Hans Kelsen and Hermann Heller in Weimar, Oxford: Clarendon Press.

Ebenstein, W. (1969). The Pure Theory of Law, trans. C. H. Wilson, New York: A. M. Kelley.

Edel, G. (1998). 'The Hypothesis of the Basic Norm: Hans Kelsen and Hermann Cohen,' in S. L. Paulson and B. L. Paulson (eds), Normativity and Norms: Critical Perspectives on Kelsenian Themes, Oxford: Oxford University Press, pp. 195-219.

Ehs, T. (ed.) (2009). Hans Kelsen. Eine politikwissenschaftliche Einführung, Baden-Baden: Nomos.

Favuzzi, P. (2019). 'Hans Kelsen's and Ernst Cassirer's Conception of Natural Law,' in P. Langford, I. Bryan and J. McGarry (eds), Hans Kelsen and the Natural Law Tradition, Leiden: Brill, pp. 327-371

Gabriel, G. (2016). 'Psychologismus,' in J. Mittelstraß (ed.), Enzyklopädie Philosophie und Wissenschaftstheorie, 2nd rev. and enl. ed., Vol. 6, Stuttgart: J. B. Metzler, pp. 498-500.

García-Salmones Rovira, M. (2011). 'On Kelsen's Sein: An Approach to Kelsenian Sociological Themes,' No Foundations: Journal of Extreme Legal Positivism, Vol. 8, pp. 41-70.

García-Salmones Rovira, M. (2013). The Project of Positivism in International Law, Oxford: Oxford University Press. 
Gordon, P. E. (2010). Continental Divide: Heidegger, Cassirer, Davos, Cambridge, MA: Harvard University Press.

Heidemann, C. (1997). Die Norm als Tatsache. Zur Normentheorie Hans Kelsens, Baden-Baden: Nomos.

Hermens, F. A. (1941). Democracy or Anarchy? A Study of Proportional Representation, Notre Dame: The Review of Politics.

Hobbes, T. (1651). Leviathan, London: Andrew Cooke.

Hobe, K. (1973). 'Emil Lasks Rechtsphilosophie,' Archiv für Rechts- und Sozialphilosophie, Vol. 59, No. 2, pp. 221-235.

Holzhey, H. (1986). 'Kelsens Rechts- und Staatslehre in ihrem Verhältnis zum Neukantianismus,' in S. L. Paulson and R. Walter (eds), Untersuchungen zur Reinen Rechtslehre. Ergebnisse eines Wiener Rechtstheoretischen Seminars 1985, Vienna: Manz, pp. 167-192.

Horkheimer, M. and T. W. Adorno (2000). Dialektik der Aufklärung. Philosophische Fragmente, Frankfurt am Main: Fischer.

Husserl, E. (1970). Logical Investigations, trans. J. N. Findlay, London: Routledge.

Jellinek, G. (1906). Verfassungsänderung und Verfassungswandlung, Berlin: O. Häring.

Kant, I. (1991). Political Writings, 2nd ed. (H. S. Reiss), Cambridge: Cambridge University Press.

Kant, I. (1998). Critique of Pure Reason, trans. and ed. P. Guyer and A. W. Wood, Cambridge: Cambridge University Press.

Kaufmann, E. (1921). Kritik der neukantischen Rechtsphilosophie. Eine Betrachtung über die Beziehungen zwischen Philosophie und Rechtswissenschaft, Tübingen: Mohr Siebeck.

Kelsen, H. (1919). 'Zur Theorie der juristischen Fiktionen: Mit besonderer Berücksichtigung von Vaihingers Philosophie des Als Ob,' Annalen der Philosophie, Vol. 1, pp. 630-658.

Kelsen, H. (1920). Vom Wesen und Wert der Demokratie, Tübingen: Mohr Siebeck.

Kelsen, H. (1921). 'Der Staatsbegriff der ,verstehenden Soziologie, "' Zeitschrift für Volkswirtschaft und Sozialpolitik, Vol. 1, pp. 104-119.

Kelsen, H. (1923a). Hauptprobleme der Staatsrechtslehre. Entwickelt aus der Lehre vom Rechtssatze, 2nd ed., Tübingen: Mohr Siebeck.

Kelsen, H. (1923b). Sozialismus und Staat, 2nd ex. ed., Leipzig: C. L. Hirschfeld.

Kelsen, H. (1925). Allgemeine Staatslehre, Berlin: Julius Springer.

Kelsen, H. (1928). Das Problem der Souveränität und die Theorie des Völkerrechts. Beitrag zu einer reinen Rechtslehre, 2nd ed., Tübingen: Mohr Siebeck.

Kelsen, H. (1929). Vom Wesen und Wert der Demokratie, 2nd rev. ed., Tübingen: Mohr Siebeck.

Kelsen, H. (1932). 'Verteidigung der Demokratie,' Blätter der Staatspartei, Vol. 2., pp. 90-98.

Kelsen, H. (1946). Society and Nature: A Sociological Inquiry, London: Kegan Paul.

Kelsen, H. (1948). The Political Theory of Bolshevism, Berkeley: University of California Press.

Kelsen, H. (1955). 'Foundations of Democracy,' Ethics, Vol. 66, No. 1, pp. 1-101.

Kelsen, H. (1957). What is Justice? Justice, Law, and Politics in the Mirror of Science: Collected Essays by Hans Kelsen, Berkeley: University of California Press. 
Kelsen, H. (1968a). 'Die Rechtswissenschaft als Norm- oder als Kulturwissenschaft: Eine methodenkritische Untersuchung,' in H. Klecatsky, R. Marcic and H. Schambeck (eds), Die Wiener rechtstheoretische Schule. Schriften von Hans Kelsen, Adolf Merkl, Alfred Verdross, Vol. 1, Vienna: Europa Verlag, pp. 37-93.

Kelsen, H. (1968b). 'Über Grenzen zwischen juristischer und soziologischer Methode,' in H. Klecatsky, R. Marcic and H. Schambeck (eds), Die Wiener rechtstheoretische Schule. Schriften von Hans Kelsen, Adolf Merkl, Alfred Verdross, Vol. 1, Vienna: Europa Verlag, pp. 3-36.

Kelsen, H. (1968c). 'Das Verhältnis von Staat und Recht im Lichte der Erkenntniskritik,' in H. Klecatsky, R. Marcic and H. Schambeck (eds), Die Wiener rechtstheoretische Schule. Schriften von Hans Kelsen, Adolf Merkl, Alfred Verdross, Vol. 1, Vienna: Europa Verlag, pp. 95-148.

Kelsen, H. (1968d). 'Der Staatsbegriff und die Psychoanalyse,' in H. Klecatsky, R. Marcic and H. Schambeck (eds), Die Wiener rechtstheoretische Schule. Schriften von Hans Kelsen, Adolf Merkl, Alfred Verdross, Vol. 1, Vienna: Europa Verlag, pp. 209-214.

Kelsen, H. (1968e). 'Über Staatsunrecht,' in H. Klecatsky, R. Marcic and H. Schambeck (eds), Die Wiener rechtstheoretische Schule. Schriften von Hans Kelsen, Adolf Merkl, Alfred Verdross, Vol. 1, Vienna: Europa Verlag, pp. 957-1057.

Kelsen, H. (1968f). 'Naturrecht und positives Recht: Eine Untersuchung ihres gegenseitigen Verhältnisses,' in H. Klecatsky, R. Marcic and H. Schambeck (eds), Die Wiener rechtstheoretische Schule. Schriften von Hans Kelsen, Adolf Merkl, Alfred Verdross, Vol. 1, Vienna: Europa Verlag, pp. 215-244.

Kelsen, H. (1968g). 'Das Problem des Parlamentarismus,' in H. Klecatsky, R. Marcic and H. Schambeck (eds), Die Wiener rechtstheoretische Schule. Schriften von Hans Kelsen, Adolf Merkl, Alfred Verdross, Vol. 2, Vienna: Europa Verlag, pp. 1661-1687.

Kelsen, H. (1968h). 'Wer soll der Hüter der Verfassung sein?,' in H. Klecatsky, R. Marcic and H. Schambeck (eds), Die Wiener rechtstheoretische Schule. Schriften von Hans Kelsen, Adolf Merkl, Alfred Verdross, Vol. 2, Vienna: Europa Verlag, pp. 1873-1922.

Kelsen, H. (1968i). 'Demokratie,' in H. Klecatsky, R. Marcic and H. Schambeck (eds), Die Wiener rechtstheoretische Schule. Schriften von Hans Kelsen, Adolf Merkl, Alfred Verdross, Vol. 2, Vienna: Europa Verlag, pp. 1743-1776.

Kelsen, H. (1973). 'God and the State,' in H. Kelsen, Essays in Legal and Moral Philosophy, trans. P. Heath, Dordrecht: D. Reidel, pp. 61-82.

Kelsen, H. (1981). Der soziologische und der juristische Staatsbegriff. Kritische Untersuchung des Verhältnisses von Staat und Recht, Amsterdam: Scientia.

Kelsen, H. (1992). Introduction to the Problems of Legal Theory, trans. B. L. Paulson and S. L. Paulson, Oxford: Oxford University Press.

Koller, P. (1982). 'Zu einigen Problemen der Rechtfertigung der Demokratie,' Rechtstheorie, Beiheft 4: Ideologiekritik und Demokratietheorie bei Hans Kelsen, pp. 319-343.

Koskenniemi, M. (2001). The Gentle Civilizer of Nations: The Rise and Fall of International Law 1870-1960, Cambridge: Cambridge University Press.

Krijnen, C. and A. Noras (eds) (2012). Marburg versus Südwestdeutschland. Philosophische Differenzen zwischen den beiden Schulen des Neukantianismus, Würzburg: Königshausen \& Neumann. 
Lagi, S. (2007). El Pensamiento Político de Hans Kelsen (1911-1920): Los Orígenes de 'De la Esencia y Valor de la Democracia', Madrid: Biblioteca Nueva.

Lefort, C. (1988). Democracy and Political Theory, trans. D. Macey, Minneapolis: University of Minnesota Press.

Lefort, C. (1994). 'Staline et le stalinisme,' in C. Lefort, L'Invention démocratique, Paris: Fayard, pp. 107-127.

Lübbe, W. (1991). Legitimität kraft Legalität. Sinnverstehen und Institutionenanalyse bei Max Weber und seinen Kritikern, Tübingen: Mohr Siebeck.

Michels, R. (1911). Zur Soziologie des Parteiwesens in der modernen Demokratie. Untersuchungen über die oligarchischen Tendenzen des Gruppenlebens, Leipzig: Werner Klinkhardt.

Minkkinen, P. (2005). 'Why Is Law a Normative Discipline? On Hans Kelsen's 'Normology," Res Publica, Vol. 11, pp. 235-249.

Mock, E. (1982). 'Hans Kelsens Verhältnis zum Liberalismus,' Rechtstheorie, Beiheft 4: Ideologiekritik und Demokratietheorie bei Hans Kelsen, pp. 439-444.

Mommsen, W. J. (1989). The Political and Social Theory of Max Weber: Collected Essays, Cambridge: Polity.

Oakes, G. (1988). Weber and Rickert: Concept Formation in the Cultural Sciences, Cambridge, MA: MIT Press.

Pasquino, P. (1995). 'Penser la démocratie: Kelsen à Weimar,' in C.-M. Herrera (ed.), Le droit, le politique autour de Max Weber, Hans Kelsen, Carl Schmitt, Paris: L'Harmattan, pp. 119-131.

Paulson, S. L. (1992). 'The Neo-Kantian Dimension of Kelsen's Pure Theory of Law,' Oxford Journal of Legal Studies, Vol. 12, No. 3, pp. 311-332.

Paulson, S. L. (1993). 'Die unterschiedlichen Formulierungen der „Grundnorm,“" in A. Aarnio, S. L. Paulson, O. Weinberger, G. H. v. Wright and D. Wyduckel (eds), Rechtsnorm und Rechtswirklichkeit. Festschrift für Werner Krawietz zum 60. Geburtstag, Berlin: Duncker \& Humblot, pp. 53-74.

Paulson, S. L. (1998). 'Four Phases in Hans Kelsen's Legal Theory? Reflections on a Periodization,' Oxford Journal of Legal Studies, Vol. 18, No. 1, pp. 153-166.

Paz, R. Y. (2015). 'Kelsen's Pure Theory of Law as "a Hole in Time,"' Monde(s), Vol. 7, pp. 75-94.

Pitkin, H. F. (1967). The Concept of Representation, Berkeley: University of California Press.

Plato. (1888). Republic, trans. B. Jowett, Oxford: Clarendon Press.

Poscher, R. (2000). 'Heinrich Triepel-Introduction,' in A. J. Jacobson and B. Schlink (eds), Weimar: A Jurisprudence of Crisis, Berkeley: University of California Press, pp. 171-176.

Rousseau, J.-J. (1797). Du contrat social, Paris: Mourer et Pinparé.

Sartori, G. (2005). Parties and Party Systems: A Framework for Analysis, Colchester: ECPR Press.

Schluchter, W. (1981). The Rise of Western Rationalism: Max Weber's Developmental History, trans. G. Roth, Berkeley: University of California Press.

Schmitt, C. (1988). The Crisis of Parliamentary Democracy, trans. E. Kennedy, Cambridge, MA: MIT Press.

Schmitt, C. (1994). Positionen und Begriffe im Kampf mit Weimar - Genf Versailles, 1923-1939, 3rd ed., Berlin: Duncker \& Humblot.

Schmitt, C. (2009). Politische Theologie. Vier Kapitel zur Lehre von der Souveränität, 9th ed., Berlin: Duncker \& Humblot. 
Schmitt, C. (2010). Verfassungslehre, 10th ed., Berlin: Duncker \& Humblot.

Schmitt, C. (2015). Glossarium. Aufzeichnungen aus den Jahren 1947 bis 1958, 2nd ed., Berlin: Duncker \& Humblot.

Serres, M. (1974). Hermès III: La Traduction, Paris: Éditions de Minuit.

Spann, O. (1922). 'Der Streit um die Möglichkeit und das Wesen der Gesellschaftslehre,' Zeitschrift für Volkswirtschaft und Sozialpolitik, Vol. 2, pp. 197-225.

Strauss, L. (1953). Natural Right and History, Chicago: University of Chicago Press.

Szakolczai, A. (2011). 'Eric Voegelin and Neo-Kantianism: Early Formative Experience or Late Entrapment?', in L. Trepanier and S. F. McGuire (eds), Eric Voegelin and the Continental Tradition: Explorations in Modern Political Thought, Columbia: University of Missouri Press, pp. 137-165.

Tannous, T. S. (2018). O Aluno do Aluno: A Controvérsia entre Hans Kelsen e Fritz Sander, São Paulo: Quartier Latin.

Topitsch, E. (1982). 'Hans Kelsen - Demokrat und Philosoph,' Rechtstheorie, Beiheft 4: Ideologiekritik und Demokratietheorie bei Hans Kelsen, pp. 11-27.

Triepel, H. (1927). Die Staatsverfassung und die politischen Parteien, Berlin: Druck der Preußischen Druckerei- und Verlags-Aktiengesellschaft.

Tschannen, O. (1992). Les théories de la sécularisation, Geneva: Droz.

Tyrell, H. (1994). 'Max Webers Soziologie - eine Soziologie ohne „Gesellschaft,“" in G. Wagner and H. Zipprian (eds), Max Webers Wissenschaftslehre, Frankfurt am Main: Suhrkamp, pp. 390-414.

Voegelin, E. (1936). Der autoritäre Staat. Ein Versuch über das österreichische Staatsproblem, Vienna: Springer.

Voegelin, E. (2003), 'Ought in Kant's System,' in E. Voegelin, Collected Works, Vol. 8 (Published Essays 1929-1933), ed. T. W. Heilke and J. v. Heyking, Columbia: University of Missouri Press., pp. 180-227.

Wagner, G and C. Härpfer (2015a). 'Neo-Kantianism and the Social Sciences: From Rickert to Weber,' in N. d. Warren and A. Staiti (eds), New Approaches to Neo-Kantianism, Cambridge: Cambridge University Press, pp. 171-185.

Wagner, G. and C. Härpfer (2015b). 'Max Weber und die Naturwissenschaften,' in M. Endreß, K. Lichtblau and S. Moebius (eds), Zyklos 1. Jahrbuch für Theorie und Geschichte der Soziologie, Wiesbaden: Springer, pp. 169-194.

Walter, R., C. Jabloner and K. Zeleny (eds) (2008). Der Kreis um Hans Kelsen. Die Anfangsjahre der Reinen Rechtslehre, Vienna: Manz.

Ward, I. (1992). 'Radbruch's 'Rechtsphilosophie:' Law, Morality and Form,' Archiv für Rechts- und Sozialphilosophie, Vol. 78, No. 3, pp. 332-354.

Weber, M. (1978). Economy and Society, ed. G. Roth and C. Wittich, Berkeley: University of California Press.

Weber, M. (2012). Collected Methodological Writings, ed. H. H. Bruun and S. Whimster, Abingdon: Routledge.

Weinberger, O. (1982). 'Rechtspositivismus, Demokratie und Gerechtigkeitstheorie,' Rechtstheorie, Beiheft 4: Ideologiekritik und Demokratietheorie bei Hans Kelsen, pp. 501-523. 


\title{
Elitism, Populism and Pluralism
}

\author{
A Conclusion
}

The study of Max Weber's, Carl Schmitt's and Hans Kelsen's thinking on modern democracy allows us to take stock of the origins, insights and limits of the three main theoretical models that political science, with the help of its many neighbouring disciplines, developed to interpret the rise, fall, rebirth and spread of democratic forms of rule during the twentieth century. Namely: elitism, populism and pluralism. These "isms" are not political ideologies in the conventional sense of the term, inherited from the nineteenth century, but neither do they represent merely scientific, value-free positions in an academic argument. ${ }^{1}$ Rather, they stand for theoretical stances in disputes over the nature and prospects of modern democracy, which are as much scholarly as they are inherently political. In other words, theoreticians of democratic elitism, populism and pluralism seek to tell us not only what modern democracy really is and how to study it empirically, but also how well or unwell it is doing, what its achievements and failings are. To do so, they necessarily avail themselves, implicitly or explicitly, of a conception of what democracy ought to be like, of what makes it a legitimate form of rule, arguably even the only legitimate form of rule in the modern age. In this concluding chapter, I connect these three theoretical stances, which emerged as consistent corpuses only well into the second half of the twentieth century, with their avowed or unacknowledged ancestry in the thought of Weber, Schmitt and Kelsen. My aim is to show that the boundaries separating them from each other are fluid and porous, and that a thoughtful grasp of the complexities of modern democracy is only possible by taking the insights of each, as well as their failures, into account. Just as the intellectual universes of Weber, Schmitt and Kelsen, despite the fierce demarcations they - and especially the latter two-were engaged in, intersect at various points, so is the intricate richness of modern democracy graspable in its full extent only if one carefully considers its elitist, populist and pluralist dimensions. And this is a precondition for envisioning possible ways out of democracy's current impasses. 


\section{Towards a Minimal Definition: Competitive-Democratic Elitism without a Philosophical-Historical Diagnosis of Modernity}

It has been the strange fate of the ambivalent analysis Max Weber offered of democracy, based on his equally ambivalent diagnosis of modernity, that it was taken to be the precursor of the so-called minimal definition of democracy, which present-day, empirically oriented political science generally works with. I qualify this fate as strange because, even though mainstream political scientists share with Weber, to use Kelsen's (1968: 1745) apt expression, 'the hunger for reality," they think they can fully satiate it to the point of cleansing reality from ambiguity and irrationality altogether, something which Weber knew to be impossible. Thus, they are fixated on finding neat concepts and definitions, which render themselves easily amenable to empirical operationalization, that is, to straightforward confirmation or infirmation by relating the empirical material to the formal conceptual definition. This procedure is, according to the interpretation of Weber offered in Chapter 1 of this volume, contrary to the spirit of the German scholar's life-work.

The minimal definition states that democracy is a regime where the chief political elites are selected through competitive, regularly held, free and fair elections, organized in full respect of the principle of equal and universal suffrage. This definition, with slight modifications and occasional inflections of emphasis, has been developed and endorsed by a long tradition of empirical democratic theory, which consolidated in the post-WWII era (Dahl, 1956; Sartori, 1962; Huntington, 1991; Przeworski, 1991). ${ }^{3}$ The beauty of such a definition, for the empirically oriented student of democracy, is that it allows one to circumvent endless philosophical speculations concerning the sources and purposes of democracy, to discard obscure, hardly operative concepts such as the "will of the people" or the "common good," and to focus instead on whether one's research objects fulfil a set of formal prerequisites, of procedural minima which ensur that the outcomes of the democratic process, irrespective of their specific content, were fairly reached. A sharp distinction between democracies and non-democratic regimes was thus near at hand. For political scientists engaging in large-N, quantitative-comparative studies, this allowed them to pursue their endeavour by way of institutional analysis, referring primarily to the constitutional and electoral laws of the polities they studied to sort them out as democratic or autocratic. Those who engaged in case studies and historical-comparative research, however, could not content themselves with such a strictly formalist approach. They had to dig deeper into the specifics of the empirical case(s) at hand, complex historical lineages included, but the minimal definition still allowed them to classify a regime as democratic, regardless of other 
supplementary qualifications, if the absence of pervasive electoral fraud, combined with the effective guarantee of civil and political liberties, could be empirically confirmed (Collier and Levitsky, 1997: 433-434).

There are, to be sure, undeniable affinities between the approaches of post-WWII empirical democratic theory, with their endorsement of a minimal definition of democracy as competitive elitism, and certain tendencies in Max Weber's sociologies of domination and the state, particularly in their later, more positivistic formulations. ${ }^{4}$ For instance, in his 1919 lecture on politics as a profession and as a calling, Weber (1994: 310) famously argued that the modern state could 'only be defined sociologically in terms of a specific means ${ }^{5}$ peculiar to it-i.e. the monopoly of legitimate physical violence within a territory - thus rejecting both teleological definitions, which posited state-specific ends or purposes, and axiological ones, which saw the state as a carrier of values. When it came to democracy, however, Weber did not offer such a means-centred, or for that matter any other, clear-cut definition.

Somewhat differently, and with a more solid basis in Weber's actual sociological work and theoretical categories, one could argue that the empirical theorists sought to accomplish for the concept of democracy something akin to what Weber had performed for the conception of legitimacy, that is, rescuing it from the troubled waters of philosophical speculation and controversy for the sake of an approach amenable to empirical validation. As long as the empirical theorists remain at the formal level of institutional description and analysis, they can avoid the methodological issues of inferring meaning from, or imputing meaning to, reality, with which Weber grappled. In that case, however, the critique that Kelsen (1921) unjustly directed at Weber would be rightfully applied to them, for they would be operating with normative concepts taken over from legal science. If they step beyond formal analysis, so as to tackle the question of what free and fair elections actually mean for the participants in the political process, then empirical theorists of democracy can hardly avoid getting entangled - even if they often remain blissfully unaware of such an entanglement-in the intractable, but nevertheless stimulating once duly acknowledged, problems of meaning and Verstehen. ${ }^{6}$

However, ignorance of the methodological quandaries of interpretive sociology, and their swift, mostly unconscious replacement by an empirical positivism fully dominated by quantitative methods, is not the most unfortunate violence done by the empirical democratic theorists to the spirit of Weber's scholarly endeavour. More relevant and regrettable, in my view, is the decoupling of Weber's undoubtedly elitist views on democracy, which nonetheless did not form a consistent theoretical model, from his ambivalent diagnosis of modernity. The philosophical-historical breadth of his thought was thus sacrificed at the altars of definitional clarity, "realism" and empirical operativeness. To assess this restrictive reinterpretation, which Weber himself can be said to have induced in 
some instances of his work, ${ }^{7}$ as well as the nexus between Weber and the Austrian-born economist Joseph Schumpeter, who put forth the first and most influential minimal definition of democracy, we turn now to the narrative offered by Held (2006: ch. 5) in his overview of different Models of Democracy.

David Held's Models of Democracy, first published in 1988, is widely used as a textbook by university instructors in political science in their undergraduate courses in democratic theory. It is arguably still the best comprehensive account of theories of democracy, for it offers a lucid and accessibly written exposition, analysis and critique of ten different models, ranging from classical Athens to the prospects of a global cosmopolitan democracy. In his treatment of twentieth-century models, Held (2006: 125) starts with 'competitive elitism' and the 'technocratic vision' he critically deems to undergird it. According to him, '[i]t was in Max Weber's thought, above all, that a new model of democracy, which I shall generally refer to as competitive elitism, received its most profound expression.' This claim, however, is immediately qualified by the warning that 'Weber wrote relatively little about this model directly' (ibid.). Competitive-democratic elitism is, hence, a theoretical reconstruction based on remarks scattered both in the sociological and in the political writings of Max Weber, most of which did not focus primarily on the topic of democracy. Notwithstanding, as I sought to bring to the fore in this volume's chapter on Weber, these views on democracy emerge from the thick philosophical-historical background of an ambivalent account of the modern age. Held, whose perspective, far from being identical with that of the empirical theorists, is sensitive to the normative and idealistic dimensions of democratic theory, is well aware of such a background, and does not fail to point out the ambivalences and paradoxes at the heart of Weber's story of modernity. Yet, to my mind, he misses the sharpness of the paradox when, in too liberal-democratic a vein, he attributes to Weber the view that 'the liberal polity c[ould] only be defended... on procedural grounds' (Held, 2006: 128). ${ }^{8}$ The nature of the paradox is, indeed, such that, although the rational-legal or procedural grounds are an indispensable feature of modern democratic rule, their tendency to abolish and replace all other types of authority harbours at the same time the menacing possibility of collapsing into hitherto unknown forms of enslavement and political petrification. Held's emphasis on Weber's liberal defence of a procedural rule of law neglects that the German thinker tried desperately to conciliate it with rescuing some degree of personal authority, resting on charismatic grounds, from the progress of bureaucratic rule. For charisma was, according to Weber, the only conceivable source of political innovation. The British author stresses with good reason the 'prophetic' quality of Weber's work in light of the fact that he warned about the impending menace of totalitarian bureaucracy before the age of Stalinism and state socialism in Eastern Europe 
(Held, 2006: 138), but forgets to consider Weber's blindness to the possibility of an equally totalitarian combination of charismatic leadership with bureaucratic one-party rule, exemplified in its most extreme form by Nazism. The utmost logically permissible development of Weber's views is hence, according to Held (2006: 137) — and contra Mommsen (1974: 408-413) — not the Schmittian replacement of liberal democracy by neo-authoritarian forms of rule, but rather a 'highly restrictive model of democracy,' which Schumpeter would later articulate, to the delight of mainstream Western political science, with a definitional clarity that Weber never bothered to achieve.

In Capitalism, Socialism and Democracy, originally published in 1942, Schumpeter (1976: 269) provided the first and arguably definitive minimal definition of democracy as 'that institutional arrangement for arriving at political decisions in which individuals acquire the power to decide by means of a competitive struggle for the people's vote.' The Austrian-American economist considered this definition superior to the one advanced by what he labelled 'the classical doctrine of democracy,' defined as 'that institutional arrangement for arriving at political decisions which realizes the common good by making the people itself decide issues through the election of individuals who are to assemble in order to carry out its will' (Schumpeter, 1976: 250). As critics have pointed out, this 'classical' model is a conveniently constructed 'straw man' (Pateman, 1970: 17), amalgamating notions from diverse intellectual provenance (Rousseauian, utilitarian, perhaps also Marxian), in comparison to which Schumpeter's alternative theory would display its greater adherence to the empirical facts of modern democracy.

In his introduction to Weber's Economy and Society, Guenther Roth claims that there is an almost perfect match between Schumpeter's model and Weber's views on democracy (see Weber, 1978: xcii). To be sure, the influence of the latter on the former is much greater than the few explicit references to Weber in Capitalism, Socialism and Democracy would suggest. ${ }^{9}$ However, our own research in the present volume indicates that there may be other stimuli, apart from the Weberian, nurturing Schumpeter's approach. Indeed, although the Austrian jurist is not mentioned once, there is a distinct Kelsenian ring to Schumpeter's (1976: 250 and passim) insistence on democracy as a method rather than as a value in itself, as well as to his propensity to reduce concepts to nutshell definitions and to operate with stern dichotomies. Moreover, Schumpeter's (1976: 251) notion that there is 'no such thing as a uniquely determined common good that all people could agree on or be made to agree on by the force of rational argument' bears striking resemblances, though the phraseology differs, to Kelsen's (1929: 22) exposure of a presupposed unifying general interest as a 'metapolitical illusion.' Finally, Schumpeter's (1976: 263) assertion that 'the volonté générale..., the will of the people is the product and not the motive power of the political process' is akin to Kelsen's 
conception of the will of the democratic state not as a real, pre-existing will, but as a construct that emerges from a larger, self-generative and dynamic process. The crucial difference being, of course, that while for Kelsen this was a normative construction, occurring in the sphere of ideality and leading to the creation of legal norms, Schumpeter conceived it as an empirical process leading to the selection or production of political leaders through electoral competition. This empirical orientation, in turn, brings him again closer to a Weberian orbit. And, perhaps most importantly, it offered empirically oriented political scientists in the aftermath of the Second World War precisely that which they most craved for, namely, 'a reasonably efficient criterion by which to distinguish democratic governments from others' (Schumpeter, 1976: 269). ${ }^{10}$

In other respects, however, Schumpeter veers from Weberian or Kelsenian-sounding tropes to the vicinities of Carl Schmitt's perspective. A case in point is his pessimistic anthropology and dismal view of the rational capacities of the masses. While Kelsen (1929: 6), too, conceded that there was a certain "primitivism" to the democratic ideal, this did not involve an anthropologically pessimistic presupposition, but rather the realization that the primordial call for freedom from society was unattainable and self-defeating, and therefore the freedom of anarchy had to be replaced by the freedom of democracy. Schumpeter (1976: 262), for his part, sees 'the typical citizen' revert to 'a primitive again' in the specific sense of 'drop[ping] down to a lower level of mental performance as soon as he enters the political field.' The average individual, who in his everyday economic activity was still able to preserve a certain degree of rationality by having a grasp of the probable immediate consequences of his actions, falls prey to the most basic, infantile instincts and criminal tendencies when he engages in politics, a domain which is far removed from the typical citizen's ordinary life experience. If Schmitt had to fabricate the intellectual ancestors of the anthropological pessimism undergirding his political theology and conception of "the political,"11 Schumpeter found them ready at hand in the crowd psychology of Gustave Le Bon. Even though Le Bon might have overemphasized 'the realities of human behavior when under the influence of agglomeration,' his work is deemed to have a general significance that is 'by no means confined to mobs rioting in the narrow streets of a Latin town' (Schumpeter, 1976: 257). The pioneer of crowd psychology, indeed, is hold to have 'dealt a serious blow to the picture of man's nature which underlies the classical doctrine of democracy and democratic folklore about revolutions' (ibid.). Moreover, with the development of the techniques of political advertising and propaganda, it has become 'terribly easy to work up' an audience that is not physically gathered 'into a state of frenzy in which attempt at rational argument only spurs the animal spirits' (ibid.).

The reason why an 'electoral mass...incapable of action other than a stampede' (Schumpeter, 1976: 283) should nevertheless be entrusted with 
the task of selecting and dismissing decision-makers is difficult to see on the grounds of this hopeless view of collective political action. Schumpeter's minimalist model, as Held (2006: 154) keenly puts it, is 'only one small step removed from.... vision which is both anti-liberal and antidemocratic.' This small step is what separates him from Carl Schmitt's neo-authoritarian populism, the small step that might be taken to bridge the gap between 'the view that the role of the people is to produce a government' (Schumpeter, 1976: 269) and the view that the role of government is to produce, represent or incarnate the people.

\section{Envisioning a Collective Political Subject for the Modern Age: The Inescapable Attraction of Populism}

That Schumpeter himself, for reasons not entirely clear and perhaps not entirely rational, did not take that small step is a fact that certainly goes to his credit, especially considering his social background and early commitment to the Habsburg monarchy. As Scheuerman (2020: 237) perceptively remarks, the relationship between Schumpeter and Schmitt, notwithstanding the perilous proximity, remained one of rivalry, a 'friendly rivalry' perhaps, based on 'an extensive set of shared intellectual assumptions,' but a rivalry nonetheless. More relevant, however, than the strict question of the historical origins of Schumpeter's competitive-democratic elitism, which really cannot be pinned down to one single set of influences, is the broader issue of the extent to which it may have 'reformulated an onerous tradition of Central European authoritarianism in order to make it more palatable to an American audience' (ibid.). 'Whitewashed of its more openly antidemocratic rhetorical flourishes,' Scheuerman (ibid.) concludes, 'Schumpeter's contribution to this tradition proved an attractive starting point for historically and philosophically naive political scientists seeking an "empirical" alternative to the classics of normative democratic theory. ${ }^{, 12}$ However, as less naïve students of politics (see e.g. Urbinati, 1998) have underlined and as I will seek to critically reflect upon in this section, the intellectual paradox of democratic elitism goes to show that, contrary to what both elitist and populist rhetoric tirelessly proclaim, the lines of the two positions, far from being held apart by an unbridgeable rift, may very well converge to a point of indistinction.

This point of indistinction is the authoritarian temptation that lies at the outer bounds, though neither historically nor logically out-ofbounds, of the elitist and populist accounts democracy. Carl Schmitt, as I have contended in Chapter 2 of this volume, is probably the author who pushed the populist reading of democracy to its neo-authoritarian extremes. This should serve as a word of caution to all who venture to explore Schmitt's ideas with the aim of reinvigorating contemporary democracies. Chantal Mouffe, for instance, disregards such need 
to proceed with caution when she hastily makes use of Schmitt's concept of the political to instil new life into a Western democratic politics that, according to her, has gone stale due to an excessive emphasis on a Rawlsian-Habermasian-Mouffe conflates the two positions rather simplistically-conception of consensus, which ultimately favours neoliberal policies. To be sure, the Belgian theorist admits that she is 'doing violence to Schmitt's questioning, since his main concern is not democratic participation but political unity' (Mouffe, 2005: 36). ${ }^{13}$ The obvious difficulty, however, is that Schmitt's concept of the political cannot be unproblematically severed from its central concerns with political unity and personal authority to be made to serve the purposes of a regeneration of present-day democracies allegedly stultified by a lack of clear ideological alternatives. Indeed, one can hardly fail to notice how Mouffe struggles with this problem when she tries to specify the scope of her appropriation of Schmitt's understanding of "the political." Faithful to the post-foundational premises of her thinking, she evidently wishes to convey a vision of politics as a permanent, irresoluble struggle between competing, unconflatable and even incommensurable alternatives. Nevertheless, she must avoid the ultimate consequences of the extreme case, i.e. of civil war, and therefore mitigate the intensity of Schmitt's concept of the political. While the German legal and political theorist preserved such intensity by transferring it to the level of interstate relations, thus making the political unity of the state rest on the substantial homogeneity of the people and its personal representation by a dictator, Mouffe simply has to concede that the political enemy, within a democratic community, is not an enemy in the full Schmittian sense of the term. Her model of democracy is hence based upon a rather contrived distinction between agonism and antagonism. In her view, the political opponent is not the radical antagonist, whom, in the last resort, one could engage in a battle for life and death, but a legitimate adversary with a recognized right to existence. This takes the sting out of Mouffe's supposedly radical agonistic vision of democracy, compared to which the right-wing varieties of contemporary populism, based on a closed and exclusionary, rather than open and pluralist, definition of the people experience far less theoretical difficulties. The electoral success of the latter, in comparison to the meagre, isolated breakthroughs of left-wing populism, is in this sense hardly surprising and cannot be blamed - at any rate, not entirely - on social democracy's purported surrender to centrist neoliberalism. In the recently published popularization of her left populism, Mouffe (2019) disregards a whole decade's dynamics of populist politics, in Western Europe and beyond, and clings obstinately to the same theoretical and political position she had formulated at the turn of the century. In the final analysis, she cannot cope with the intensity of Schmitt's concept of the political, arguing for radical repoliticization while at the same time trying to dodge the perils of radical subversion and potential 
authoritarianism that come with it. Mouffe's failure, in any case, should not be attributed to a lack of theoretical ingenuity on her part, but rather taken as a sign that Schmitt's neo-authoritarian thinking cannot be domesticated for a constructive critique of modern democracy. ${ }^{14}$

Another attempt to read Schmitt with a left-radical democratic intent was undertaken by Andreas Kalyvas. This author interprets Schmitt as a theorist of 'the constituent power of the people' in its 'rebellious and insurgent force' (Kalyvas, 2008: 10-11). Undoubtedly, his reading deals much more deftly than Mouffe's with "the challenge of the political." Nevertheless, Kalyvas must eventually admit that Schmitt offers neither a definition nor a positive account of the people. The concept, indeed, remains thoroughly vague in Schmitt's key Weimar-era writings. Most notably, it appears rather instrumentally in the definition of the state as political unity. Schmitt (2010: 205) merely postulates the a priori existence of homogeneous peoples, or the need to create them, when he defines the state as a people in the status of political unity. The people's constituent power remains a vague, elusive, even ominous thing, which to Schmitt's mind craves for personal political representation. For the jurist from Plettenberg, the power of the people as such is never the issue, but rather the personal authority of those who can undisputedly claim to speak in the people's name. An approach that conceives of sovereignty in terms of an order-creating decision on the exception is, as I believe to have shown in this book's chapter on Schmitt, necessarily personalistic - and the people, whatever else it may be thought or construed to be, is not an actual person. Kalyvas (2008: 146ff.) acknowledges this when he recognizes the centrality of the concept of representation in Schmitt's Constitutional Theory. He could have gone one step further and accepted that Schmitt's thought bears much less relevance for a profound diagnosis of the predicaments and prospects of modern democracy than many left-radical thinkers presume.

To conclude that Carl Schmitt's thinking offers no more than a few meaningful insights on the modern democratic problem does not allow one to dismiss each and every populist reading of democracy as inevitably and inherently authoritarian. Indeed, insofar as democracy needs to envision a collective subject of self-rule, a sovereign that is not a natural person, populism is inextricably tied to it. The question is then how this inescapable relationship ought to be conceived. One of the most insightful contemporary theorists of populism suggests that it should be viewed as the ideology of democracy. According to this view, populism supplies the complex institutional arrangements of mass democracy with the transparency that they manifestly lack. While the latter, through intricate procedures of representation and intermediation, have 'br [ought] the people to politics' in the modern age, populism as an ideology 'tak[es] politics to the people, by allowing them to form an intelligible and persuasive mental picture of it' (Canovan, 2002: 26). ${ }^{15}$ This engenders, by necessity, 
a paradox, for 'while democracy, with its claims of inclusiveness, needs to be comprehensible to the masses, the ideology that seeks to bridge the gap between people and politics misrepresents (and cannot avoid misrepresenting) the way that democratic politics necessarily works' (ibid.). Populists with sincere democratic concerns or hidden authoritarian intents thrive on this paradox, which 'lies at the heart of modern democracy' (Canovan, 2002: 25).

The paradox, however, is not merely one that pits ideology and practice against one another. The need for an intense investment in populist ideology also stems from the formal, in the aesthetical sense of the term, predicament of modern democracy. Compared with the divineright monarchy it came to abolish, modern democracy evinces a distinct symbolic deficit, which became apparent in the aftermath of one of its founding gestures: the beheading of Louis XVI at the Place de la Révolution in 1793, which dealt an irrecoverable blow to the allegedly sacred and immortal nature of the monarchy. ${ }^{16}$ Such powerful, but strictly negative, symbolic gesture generated a vacuum which modern democracy cannot — and perhaps must not - fill. As Frank's (2015) stimulating essay shows, revolutionary democracy grapples with the problem of how to visualize a sovereign that, unlike the king, does not possess a body natural. It is therefore hardly surprising that the aestheticization of politics (Benjamin, 2008) is as uncongenial to modern democracy as it is "natural" to authoritarian and totalitarian regimes. To compensate for this aesthetic deficit, to look beyond its own symbolic void and past its institutional maze, democracy's all too understandable tendency is to emphasize the populist ideological component, which might endow it with an intelligible, though necessarily oversimplified, account of the modern project of collective self-determination.

Given this most intimate connection, one could at first sight deem it surprising that populist readings of democracy lay mostly dormant throughout a century which, in its second half, witnessed the triumph and spread of democratic forms of rule across the globe. Democratic populism thrived at the turn from the nineteenth to the twentieth century in East and West, ${ }^{17}$ and is surging again at the dawn of a new century, after the fadeout of the age of liberal-democratic optimism that followed the collapse of state socialism in the East. For the bulk of the twentieth century, however, it remained overshadowed by liberal anxiety and neo-authoritarian or totalitarian reinterpretations of democracy-such as Schmitt's - in the century's first half, and by competitive-elitist and pluralist accounts in its second half. In fact, in the 1960s and 1970s, populism was mostly thematized not in relation to democracy per se, but rather to development, as an alternative or abnormal pathway-distinct from both capitalism and socialism - to the modern social and economic world..$^{18}$ It is, hence, hardly surprising that one of the keenest theorists of democratic populism at the turn to the twenty-first century was an 
Argentinian thinker, whose reflections on the topic go back to a Latin American political context where populism was heatedly debated, especially in leftist circles, long before it had acquired any salience in Western Europe or the U. S.

Despite his long-lasting collaboration and companionship with Chantal Mouffe, Ernesto Laclau (2005a) is wise enough not to mention Carl Schmitt once in his definitive work on populism. He draws creatively on Freudian and Lacanian psychoanalysis, post-structuralist theory and Wittgensteinian philosophy to reshape and formulate new answers to the key questions of Marxist politics. Laclau (2005b: 32-33) suggests that, when thinking about populism, one should shift the framework of analysis from movements or ideologies and their contents - the so-called ontic level of analysis, which is self-defeating and gets us nowhere near a definition - to social and especially discursive practices - the ontological level — which hold the key for grasping how collective subjectivities and identities are constituted, regardless of the contents they express. The post-Marxist thinker proceeds from the anti-utopian premise that no political system can accommodate the whole range of demands that emerge in society, 'that the promise of fullness contained in the notion of an entirely self-determined social whole is unachievable' (Laclau, 2005b: 35). This 'unachievable fullness of the social whole' can, in Laclau's (2005b: 36-38) view, be expressed and understood according to two different logics, namely, difference and equivalence. The differential model is characterized by the formulation of a number of democratic demands, which the political system, addressing them on an ad hoc basis, is in the position to partially fulfil. It is a model typical of times of political stability and relatively high levels of institutional integration, where there is a widespread belief in the inclusive capacities of the political system, or, to speak in Weberian terms, where there is the belief in the system's legitimacy. The equivalential model, in contrast, starts to operate as a result of a system's institutional incapacity, i.e. as soon as several democratic demands remain unfulfilled. A popular subjectivity or identity emerges, thus, with the establishment of an equivalential link between the unfulfilled demands, and the social field becomes internally divided by an antagonistic frontier opposing the people to the institutional status quo. 'Equivalential popular discourses,' so Laclau (2005b: 38), 'divide the social into two camps: power and the underdog.' The key difference between Laclau's perspective and the neo-authoritarian populism of Carl Schmitt is plain to see. While the former sees popular subjectivities emerge "from below," from autonomous discursive practices at the margins of the political system, the German thinker conceived the people as a product of power's representative capacity and of its shaping of certain, pre-existing and pre-political, empirical "materials"-national, ethnic, racial or whatever - into a political unit(y) proper, capable of distinguishing between friend and enemy. 
Much could be said about the role of 'empty and floating signifiers' (Laclau, 2005b: 38ff.) in the structuring of popular identities, as well as about the bold claim that 'populism become[s] synonymous with politics' (Laclau, 2005b: 47), which seems to me to excessively inflate the concept of populism and deflate that of politics, but to conclude this section, I shall focus on how Laclau perceptively acknowledges that authoritarian leadership is an inherent risk, though by no means a necessary consequence, of populist politics. The author makes this point in On Populist Reason through a careful analysis of Sigmund Freud's Group Psychology (1921), which he interprets as a major breakthrough in social psychology, infinitely superior to the anxiety-driven analyses of crowd behaviourwith their inevitably authoritarian political consequences-by Le Bon and others (Laclau, 2005a: 52ff.). The crucial contribution of Freud's work, according to the Argentinian thinker, is that it allows one to understand the formation of the social bond as occurring in a continuum demarcated, at its impossible logical extremes, by 'the fully organized group' which 'acquires the secondary characteristics of the individual' on the one side, and by the total libidinal identification with 'the purely narcissistic leader' on the other side (Laclau, 2005a: 58). ${ }^{19}$

In my view, these two extremes illuminate populism's condition, to build on Canovan's (1999: 3) apt formulation, as 'a shadow cast by democracy itself.' In this earlier text, Canovan suggests a slightly different reading of the paradox of modern democracy. Drawing on Oakeshott's distinction between The Politics of Faith and the Politics of Scepticism (1996), she argues that modern democracy has two faces, one redemptive and the other pragmatic. The pragmatic face corresponds to the complex institutional realities of modern democratic polities, which simultaneously constitute and operationalize the people's power and limit its exercise. Against this pragmatic vision rises the redemptive face of democracy, with its promise of spontaneous self-rule and salvation through politics. These 'two faces of democracy,' Canovan (1999: 10) holds, 'are a pair of squabbling Siamese twins, inescapably linked, so that it is an illusion to suppose that we can have one without the other.' Populism, of course, is inextricably tied to the redemptive and Promethean vision, and emerges as a potent political movement from the tensions between the latter and the institutional-pragmatic understanding. However, as Laclau's interpretation of Freud suggests, the redemptive and salvific vision of democracy is itself Janus-faced, for it harbours both promise and danger, both the unachievable horizon of emancipation through collective self-determination and the inherent risk of a relapse into authoritarian - or even of a collapse into totalitarian - rule. Here, again, we cannot have the one without the other; one cannot pursue the populist promise of democracy without running the risk of authoritarianism. Arditi (2004: 141), in a stimulating reply to Canovan's article, forwards the Derridean notion of spectrality as a fruitful substitute for 
the image of the shadow to understand this ambiguity at the heart of the redemptive vision of democracy, for a spectre oscillates undecidably between 'a visitation and a more threatening haunting.' Populism, in sum, thrives on the unfulfillable, yet indispensable, promise of comprehensive collective emancipation harboured by modern democracy, which cannot be content with any of its institutional materializations, while at the same time threatening to 'morph into democracy's nemesis' (Arditi, 2004: 143). There is no democracy without populism, even if populism can destroy democracy - here, no doubt, lies one of the most intriguing paradoxes of the modern political condition.

\section{Democracy without the Spectre of Caesarism? Pluralism and Beyond}

Elitism and populism are thus, pace Mudde (2004: 543), neither opposites nor mirror images of each other, but rather two sides of the same modern democratic coin, which can become blurred and even morph into something which is not democracy anymore. Pluralism, in turn, supplies the complex geometry of modern democracy with a further dimension, turning its metaphorical structure into a polyhedron. For pluralism, too, far from being the opposite of either elitism or populism, constitutes an ineradicable element in any theory of democracy that takes the modern condition seriously into account. This interweaving of different theoretical conceptions becomes evident when one looks closer into the most sophisticated elitist and populist visions of modern democracy. Max Weber's democratic elitism, which-let us stress again - never acquired a definitive theoretical elaboration, emerges against the backdrop of a philosophical-historical account that underscores the indelible pluralism of the modern age, where every person must choose for her or himself which values to adhere to and which causes to further, after the spell of all-encompassing theological cosmologies was broken. And even Schumpeter's simplified competitive elitism requires, if there is to be competition for the people's vote in any meaningful sense, at least one contender to challenge the incumbent office-holders, i.e. a two-party system. To speak in the terms of Schumpeter's scientific field, the structure of the electoral market, even if it cannot aspire to realize the ideal-type of perfect competition, must remain oligopolistic for a regime to rightfully claim to be a democracy. Laclau's populist vision, in turn, lays claim - a claim I see no compelling reason to dispute, despite some reservations - to being both radical and plural. Radical, in the sense that it is foremost interested in the fleeting moments of institutional disruption, where "the people as underdog" rises up to challenge the status quo. Plural, to the extent that (1) popular subjectivities are understood as fluid discursive constructions, whose political sign can fluctuate from left to right and vice versa, and (2) the equivalential chain which constitutes "the people" does not fully 
absorb and negate the differential singularity of the democratic demands that compose it.

Nevertheless, in contrast to elitism and populism, there is a stronger case for arguing that pluralism is not cursed by the haunting spectre of authoritarianism, just as one may claim that, among the three authors discussed in depth throughout this volume, Kelsen is the only one 'whose sympathy for democracy does not bear the shadow of Caesarism' (Herrera, 1995: 9). Undoubtedly, there is some truth to these claims. However, they must be qualified with a dosage of nuance.

The empirical democratic theory which, in the aftermath of the Second World War, eagerly — and perhaps naively — embraced Schumpeter's minimal definition of democracy was in actual fact, if one looks carefully at the scholarly output of its main exponents, both elitist and pluralist. This emerges very clearly when those informed by such theory engage in case studies of how democracies actually work, rather than in large cross-national comparisons. Robert A. Dahl, one of the frontrunners of an empirically oriented, behaviouralist political science, published in 1958, in the pages of The American Political Science Review, a short but sharp critique of Charles Wright Mills's The Power Elite (1956). This influential sociological study had sought to demonstrate that there was, in the U. S., a cohesive, tightly knit elite, composed of the upper strata of the military, business and government, which monopolized the resources of power. Mills's verdict on the democratic credentials of American society was demolishing. 'America,' he stated, 'is now in considerable part more a formal political democracy than a democratic social structure, and even the formal political mechanics are weak' (Wright Mills, 2000: 274). Dahl opposed both the verdict and the theory that supported it. Starting with the latter, he outrightly denied the ruling elite theory's claim to a scientific status, arguing in a Popperian vein that it failed to stipulate 'clear criteria according to which the theory could be disproved' (Dahl, 1958: 463). According to him, notwithstanding its intuitive appeal, the ruling elite model boiled down to 'a metaphysical and polemical doctrine' (ibid.), with no scientific value.

A couple of years later, Dahl (1961) published his own empirical case study of democracy and power in the American city of New Haven, whose results were diametrically opposed to those of Wright Mills. Far from diagnosing any sort of democratic decline, Dahl sketches a transition from an oligarchic to a pluralistic social structure, which, albeit with an inevitable delay, eventually gave rise to a heterogeneous elite, comprising elements from diverse ethnic, religious, racial and class backgrounds. In Dahl's portrayal, the elites were as internally divided as the different segments of the general population that supported them; they did not act in unison nor did shared values or interests unite them. Even more so, the resources they drew upon to exert influence on political decisions were inherently diverse - some had the money, others the knowledge and 
still others the numbers in their favour. Like so many zealously "empirical" political scientists, however, Dahl, too, conflated the descriptive and prescriptive dimensions of his account. His picture of how democracy worked, in the city of New Haven in particular, but also in America/ the West at large, was also a blueprint for how it could achievably be thought to work elsewhere, namely, as polyarchic elitist pluralism. How to move from such an empirically derived paradigm to other, potentially more inclusive practices, which might broaden the scope of voices heard and enlarge their share of influence on public choices to a degree commensurate with the democratic principle of equality, is a task that Dahl and like-minded scholars conveniently deemed to be beyond the scope of their scientific endeavour. They forgot and still forget, of course, that the frontier between value-free science and ideology is much more porous and blurred than the clear-cut definitions they love to work with. ${ }^{20}$

In the European continent, however, empirical democratic theory discovered a new model of democracy, alternative to the Anglo-American, so-called majoritarian model, with its bipartisan systems and bases on either cultural homogeneity or the assimilation of diversity, when it set out to grasp how democracy worked in profoundly divided-along confessional, linguistic, ethnic or ideological lines-Western European polities after the Second World War. The new model went by the names of consociational, consensus or power-sharing democracy, and its coinage is attributed to the Dutch-American political scientist Arend Lijphart, who in 1968 published an important study on The Politics of Accommodation in the segmented society of the Netherlands. His emphasis was on elite pluralism, inter-elite compromises and internal cohesion-brought about both by formal and informal means-within each social bloc. Like Dahl's, Lijphart's work was not merely scholarly and unpolitical. His aim was not just to discern the empirical features of consensus democracy as a descriptive ideal-type, but also to advocate this alternative model, as especially his later writings show. In particular, he thought that powersharing institutions, similar to those that developed in the Netherlands, Austria, Switzerland and other Western European consociational democracies, could serve as more fertile models than the Anglo-American one to constitution drafters around the world, who were struggling to make democracy work in deeply segmented societies, many of which carrying the burdens of European colonial legacies.

Lijphart developed his model of power-sharing democracy independently from Kelsen, and based on empirical case studies or comparative analyses rather than on an attempt to relate, as far as possible, the philosophical ideal of democracy to its institutional realities. In a volume that gathers the Dutch-American political scientist's major articles, published between the late 1960s and the early 2000s, there is not one single reference to Kelsen (Lijphart, 2008). This constitutes a clear proof that Kelsen's democratic theory was ignored by mainstream post-WWII 
political science, even if, somewhat ironically, in his American exile, "the jurist of the century" could only find a place in a political science faculty. Kelsen himself, rather than just the arguable historical and philosophical naivety of empirically oriented political scientists, is largely to blame for such circumstance, considering the ferocity with which he sought to demarcate the normative from the empirical social sciences. Nevertheless, recent research has finally started to consider the affinities between consociational or power-sharing democracy and the Austrian jurist's democratic thought (see Baume and Novak, 2020).

To my mind, though he arrives at his institutional design recommendations from a very different perspective and intellectual background, Lijphart hardly adds anything substantively new-except, perhaps, for some insights stemming from the comparative dimension of his work, which Kelsen's studies lack - to what Kelsen drafted for the Austrian constitution of 1920 and advocated during the following decade in terms of institutional reform. Indeed, it seems to me that Kelsen provides a logically more robust justification for key elements of pluralist, powersharing democracy — such as the role of proportional representation, inter-party compromises, a strong protection of minority rights and a centralized, independent system of constitutional review-than Lijphart ever did, relating them clearly and compellingly to the chief democratic principles of freedom, self-determination and equality. Be that as it may, one of the major achievements of Kelsen's pluralist conception of democracy is its awareness of the gap separating the ideal from the realities of democracy and how to go about it without sacrificing the former entirely to the latter. Kelsen was well aware that although freedom as selfdetermination was the primary democratic idea, perhaps the most that really existing democracies could achieve was social peace through compromise. This is not very far away from the pragmatic view of democracy as a procedure that substitutes ballots for bullets as the legitimate means of settling divergences between group interests, or, in Przeworski's (1991: 95 ) words, as 'a system of processing conflicts without killing one another. ${ }^{21}$ However, even if this is what democracy, at the end of the day, in fact is, and maybe, though not surely, the most that it can hope to be, one is not warranted in giving up on all efforts towards further democratization, once formal political democracy is established. Kelsen's openness towards the prospect of democratizing the internal organization of the legally recognized political parties ${ }^{22}$ testifies to a more general commitment to the effort of extending democracy, beyond the formal political domain, to other social spheres. A commitment that rejects the hardboiled cynicism, often masquerading as "realism" and resulting in an oversimplified, unsophisticated elitism, which argues that the establishment of regular, free and fair elections is all there is to a transition to democracy. And also a commitment that, for obvious reasons, has spurred disapproval from liberal quarters, even if Kelsen defended certain liberal 
values and institutions more unwaveringly than many self-professed liberals in the interwar years.

Finally, Kelsen must also be credited with the merit of having tried to relate democratic pluralism to a broader philosophical perspective. According to him, democracy is inextricably tied to the relativistic worldview that underpins modern science. His concept of relativism, however, as we have argued in the previous chapter, is misleading. As it diverts Kelsen from the possibility of grasping the ultimate sources and implications of modern democratic pluralism, it also bars him from arriving at a compelling defence of democracy against authoritarian or totalitarian dissolution. Kelsen may very well have never caved in to the shadow of Caesarism, but he was helpless once that shadow was ominously cast over him and the democracy he had helped to build. In the following, final section, I will draw on Claude Lefort's concept of modern democracy's radical indeterminacy to sketch a way of conceiving the nexus between the elitist, populist and pluralist faces of democracy in a manner I believe to be theoretically fruitful, even if it is not exempt from paradox.

\section{Towards and Away from the People}

The French philosopher Claude Lefort (1988: 19) has famously portrayed the historical situation which emerges from the modern democratic revolution as one in which people experience a fundamental indeterminacy as to the basis of power, law and knowledge, and as to the basis of relations between self and other, at every level of social life. ${ }^{23}$ This new experiential condition is the consequence of the break-up of the old world, of 'the dissolution of the markers of certainty' (ibid.) ${ }^{24}$ that held it together, symbolically, as an organic whole. Such a perception of unity was achieved, as Lefort (1988: 250-254) observes with reference to Kantorowicz (1957), by the image of the king's two bodies, body natural and body politic, which in the same gesture of division also invested the political community with a mystical, transcendent significance. In the Ancien Régime, power was thus both naturalized and sacralized. This image of embodied power 'gave society,' as Lefort (1988: 17) avers, 'a latent but effective knowledge of what one meant to the other...throughout the social. $^{25}$ '[T] he revolutionary and unprecedented feature of democracy,' by contrast, is a radical gesture of disembodiment, whereby ' $[t]$ he locus of power becomes an empty place,' which 'cannot be occupied-it is such that no individual and no group can be consubstantial with it-and... cannot be represented' (ibid.). ${ }^{26}$ When the image of the cohesive body politic, personified by a king who rules by the grace of God, vanishes, '[o] nly the mechanisms of the exercise of power are visible, or only the men, the mere mortals, who hold political authority' (ibid.).

This disintegration of the medieval politico-theological grounding of social and political cohesion does not, however, throw the individual 
back to the Hobbesian bellum omnium contra omnes of a pre-social state of nature. Even if Lefort's theory of democracy developed and matured as the author moved ever further away from his Marxist formation, he still took Marxism too seriously-despite the profound dissatisfaction with Marx's naturalistic positivism, which left no room for a consideration of the autonomy of the symbolic sphere (Lefort, 1986: 141-152) — to replace it with an individualistic account (be it antagonistic or aggregative) of the nature of human sociality. As Moyn (2012: 292) keenly remarks, the move away from Marxism 'would have to share much with what it replaced: notably, an account of the collective foundations of personal autonomy, a philosophy of history and a theory of modernity.'

Now, if this is indeed the case, it obviously begs the question of the sources of collective social identities in the aftermath of the dissolution of the theologico-political image of the body. In Lefort's (1988: 218) view, social identities arise from 'a common awareness' of the 'idea of the primal dimensionality of the social, and that this implies an idea of its primal form, of its political form. ${ }^{27}$ At first glance, this passage could be interpreted as containing conspicuously Schmittian undertones. After all, is not Lefort arguing that collective identity 'presupposes the concept of the political' (Schmitt, 1963: 20)? And even more so, that it presupposes a concept of the political which, like Schmitt's, is distinctly antagonistic? However, in the very same paragraph, Lefort (1988: 218) had already chased away the suspicion of Schmittianism - and, indeed, knowingly or not, delivered a crushing blow to Schmitt's understanding of the political - when he noted 'that social division can only be definedunless of course we posit the absurd view that it is a division between alien societies - insofar as it represents an internal division. ${ }^{28}$ The philosophical source for this idea of a primal internal division of the social is Machiavelli, who, according to Lefort (2012), was the first thinker to have developed the notion of a fundamental opposition between the great and powerful on the one hand, with their drive towards domination, and the people resisting domination on the other hand. This primal opposition, situated at the symbolic level, is the

principle of internalization which can account for a specific mode of differentiation and articulation between classes, groups and social ranks, and, at the same time, for a specific mode of discrimination between markers-economic, juridical, aesthetic, religious markers-which order the experience of coexistence

(Lefort, 1988: 218).

In other words, the internal political division between rulers and ruled is the constitutive feature of democratic societies, the symbolic point of imputation to which the ever-changing empirical multiplicity of their social divisions can be referred back to. 
With his recourse to Machiavelli, Lefort adopts a key insight of the elitist tradition of political thought, and one which democratic theory, even if it intends to be a critical rather than a power-serving theory, must acknowledge. Namely, that despite the democratic principle of equality, the distinction between rulers and ruled, powerful and powerless, domination and resistance, is ineffaceable from the very idea, and not just from the reality, of modern democracy. However, by locating such distinction at the symbolic rather than at the empirical level, and insisting adamantly on the gap separating them, Lefort avoids the positivist or methodological individualist temptation - to which both Weber and Kelsen, though through very different paths, fell prey to - of reducing all references to a collective subject to masks hiding the crude and inevitable reality of the domination of man over man, which one should shred in order to expose what "actually" lies beneath the ideological façades. In Lefort's (1988: 225) own words, the 'primal division' between rulers and ruled 'is constitutive of the space we call society,' it allows us to grasp 'that this space is organized as one despite (or because of) its multiple divisions,' and the fact 'that it is organized as the same in all its multiple dimensions implies a reference to a place from which it can be seen, read and named.'29 'Even before we examine it in its empirical determinations,' he proceeds, 'this symbolic pole proves to be power; it manifests society's self-externality, and ensures that society can achieve a quasirepresentation of itself' (ibid.).

Laclau's distinction between power and "the people as underdog" constitutes one possible reading of this primal symbolic division, which stresses the need to articulate counter-hegemonic popular identities so as to give concrete expression to the antagonistic frontier that constitutes, by cutting across it, the democratic social fabric. For Laclau, as we have seen earlier, the possibility of a transformative democratic politics hinges on the possibility of a populist rupture with the institutionalized, elitist and/or pluralist, status quo. A possibility that, as he conceded, could not altogether dispel the danger of authoritarian retrogression, which was nevertheless a risk worth taking, a risk one had to run to play 'that exhilarating game that we call politics' (Laclau, 2005b: 49). Lefort, in turn, is much more circumspect in this regard, and his prudence stems from a keen awareness of the ambiguity inscribed at the heart of modern democracy. While Laclau opposed populist democratic politics to what he called the logic of difference, which was administrative and institutionfreezing even if based on electoral competition and responsiveness to a plurality of democratic demands, Lefort, for whom the spirit of democracy was much more one of resistance rather than counter-hegemonic practice, could not that easily cast his glance away from the entanglement of modern democracy and totalitarianism. ${ }^{30}$ To formulate it in a paradoxical nutshell, the difficulty is that modern democracy must at the same time move towards and away from the people, that it has to strive 
for something whose ultimate consequences it must outrightly reject, if it is not to turn into its worst enemy.

Thus, there is, on the one hand, an inescapable democratic 'movement which tends to actualize the image of the people, the state and the nation' (Lefort, 1988: 232). The belief in this potential for actualization must persist as an indispensable dimension of modern democracy. Indeed,

to find in this belief a sign of pure illusion, as liberal thought encourages us to do, is to deny the very notion of society, to erase both the question of sovereignty and that of the meaning of the institution, which are always bound up with the ultimate question of the legitimacy of that which exists. It means, for example, reducing power-or the state, which is wrongly confused with power- to an instrumental function, and the people to a fiction which simply masks the efficacy of a contract thanks to which a minority submits to a government formed by a majority; and, finally, it means regarding only individuals and coalitions of interests and opinions as real.

(Ibid.)

But if this belief in the potential actualization of popular self-rule and emancipation must endure, on the other hand, it harbours within itself the menace of a return to the image of the body, to the 'representation of a homogeneous and transparent society, of a People-as-One,' which denies social division 'in all its modes' (Lefort, 1988: 13). This is the reason why, for Lefort (1988: 213ff.), the persistence of the theologico-political in the modern age is still an open question. To steer away from the theologicopolitical temptation, a counter-movement has to 'thwart' it 'by the reference to power as an empty place and by the experience of social division,' which are also ineradicable features of the modern democratic revolution (Lefort, 1988: 232). Democracy, hence, oscillates between the promise of popular sovereignties and collective emancipations, which it cannot do without, and the need to prevent such promises from succumbing to a division and pluralism-denying populist closure. Only by acknowledging and sinking into this constitutive ambiguity, can we push the "historical adventure' of modern democracy forward and perhaps extend 'the boundaries of the possible and the thinkable' (Lefort, 1988: 179). ${ }^{31}$

\section{Notes}

1 On the relationship between ideologies and political theory, see Freeden's (1996) outstanding work.

2 For the context of Kelsen's statement, which the Austrian jurist directed at sociologists in general, see the previous chapter, p. 164, n. 77.

3 For a review article that helpfully sketches the state of the art of this research tradition as it was consolidating, see Lijphart (1972). 
4 Regardless of whether or not the chief empirically oriented theoreticians of democracy referred explicitly to Weber-some did so (e.g. Sartori), others did not (e.g. Dahl).

5 Emphasis Weber's.

6 On Kelsen's misguided critique of Weber's interpretive sociology, see the previous chapter. On the methodological issues afflicting Weber's conception of legitimacy, see Chapter 1 in this volume.

7 See, above all, the methodological and conceptual introduction to Economy and Society (Weber, 1978: ch. 1).

8 Emphasis in the original.

9 There are only two references to Weber in Capitalism, Socialism and Democracy, and none of which pertains to democratic theory (Schumpeter, 1976: 11, n. 2 and 30). The secondary literature on the relationship between Weber and Schumpeter focuses mostly on questions of economic theory and sociological theory (Collins, 1986: ch. 5; Osterhammel, 1987; Faucci, 2007). A careful critical consideration of Weber's influence on Schumpeter's theory of democracy is still lacking.

10 For instance, Samuel P. Huntington's influential study on The Third Wave of democratization, which started in the mid-1970s in Southern Europe and spread across the globe in the two following decades, is built squarely and explicitly on the Schumpeterian distinction between the "classical" and the minimalist models of democracy (Huntington, 1991: 6, n. 4). Huntington's book inspired a wave of transition-to-democracy studies as vast and global as their object of enquiry. For a critique of minimal democracy on grounds of conceptual deflation, see Plotke (2010); a defence, in a Popperian vein, is provided by Przeworski (1999). For an early lucid questioning of the transition paradigm, written when optimism about the prospect of a worldwide expansion of liberal democracy was still unrestrained, see Carothers (2002).

11 See Chapter 2 in this volume. On reminiscences of bourgeois class anxiety and Le Bon's crowd psychology in Schmitt's description of the masses, see also there p. 80, n. 29.

12 For an account contrary to Scheuerman's on the relationship between Schmitt's and Schumpeter's democratic theories, which argues that Schmitt was not the 'unacknowledged source,' but rather the 'unacknowledged adversary' of Schumpeter's 'alternative theory of democracy,' see Cherneski (2017). This commentator holds that the "classical doctrine," which Schumpeter construes so as to contrast it with his procedural reading, is in fact a shorthand for Schmitt's 'fascist theory of democracy' (Cherneski, 2017: 451, 461ff.). The evidence supporting this thesis is, in my view, rather thin. The fact that Schmitt (1988: 14), in the preface to the 1926 reedition of The Crisis of Parliamentary of Democracy, referred to Rousseau's theory explicitly as a 'classical definition' of democracy, linked to the obvious Rousseauian elements in Schumpeter's account of the "classical model," is hardly enough to justify reading Schumpeter against Schmitt, and much less does it constitute enough proof to sustain that the former was implicitly arguing against the latter. Moreover, apart from the Rousseauian motives, Schumpeter's conception of the "classical doctrine" is permeated by utilitarian resonances that are congenially un-Schmittian. In sum, though one can read elements of Schmitt's conception of democracy as substantial homogeneity in Schumpeter's rendition of the "classical doctrine," there is no solid basis to claim that Schmitt is the main source of Schumpeter's straw man.

13 Emphasis in the original.

14 Indeed, Schmitt can much more fruitfully be invoked, as Müller (2016: 52) has shown, to warn us of the danger that contemporary populist movements pose, not merely to liberal democracy, but to modern democracy proper.

15 Emphasis Canovan's. 
16 For a philosophical defence of the king's public execution as an indispensable symbolic act in the transition to popular self-rule, see Walzer (1974: 69-89).

17 See the helpful historical essays in Ionescu and Gellner (1969: 9-150).

18 Again, most of the essays in Ionescu's and Gellner's (1969) classic volume are good examples of such a trend.

19 Emphasis in the original. Kelsen, as Laclau notes in this same passage, accused Freud of hypostatizing the self-organized group by attributing to it characteristics and capacities that only the individual possesses - a critique which comes as no surprise to anyone familiar with the strict methodological individualism of Kelsen's conception of the empirical social sciences. Freud, however, replied straightforwardly that his concept of the group mind, with its capacity for collective self-organization, should indeed be understood in a literal sense and not as a mere metaphor.

20 For an interpretation-more sympathetic than mine-of Dahl's theory of polyarchic democracy, which lays emphasis on a normative turn in his later thought more pronounced than the author himself would be willing to concede, see Krouse (1982).

21 Przeworski (1999: 12, n. 2 and 15), by the way, appears to be one of the few empirical democratic theorists who has actually read Kelsen.

22 On this topic, see the previous chapter.

23 Emphasis in the original.

24 Emphasis Lefort's.

25 Emphasis in the original.

26 Emphasis Lefort's.

27 Emphasis in the original.

28 The emphasis is Lefort's on social division and mine on absurd view and internal division. There is, to my knowledge, no proof that Lefort was familiar with Schmitt's The Concept of the Political. His chief reference for political theology is Ernst Kantorowicz, but the shadow of Schmitt hovers unmistakably, even if not explicitly (see Herrero, 2015), over The King's Two Bodies.

29 Emphasis in the original.

30 Laclau (2005a: 164-171) recognizes some points of convergence between his democratic thinking and Lefort's, but mostly underscores that which sets them apart. In my view, he is to rash here in following Mouffe's verdict that Lefort implicitly identifies democracy with liberal democracy. The long excerpt we cite below shows that this verdict is manifestly incorrect.

31 Gerçek (2017), in an excellent recent essay, sees this ambiguity as a shortcoming of Lefort's theory of democracy, and proposes to turn to the phenomenology of Merleau-Ponty, Lefort's main philosophical source for the idea of democratic indeterminacy, to overcome it. According to our interpretive scheme, Gerçek would be veering towards a populist emphasis on the creation of novel, this-worldly experiences of collective subjectivity, which bears clear Laclauian resonances, and away from the pluralist stress upon the avoidance and the dangers of definitive populist closure. In contrast to this attentive commentator, however, far from interpreting it as a shortcoming, I take this ambiguity to be the keenest insight of Lefort's democratic thought.

\section{References}

Arditi, B. (2004). 'Populism as a Spectre of Democracy: A Response to Canovan,' Political Studies, Vol. 52, pp. 135-143.

Baume, S. and S. Novak (2020). 'Compromise and Publicity in Democracy: An Ambiguous Relationship,' in S. Baume and S. Novak (eds), Compromises in Democracy, Cham: Palgrave Macmillan, pp. 69-94. 
Benjamin, W. (2008). The Work of Art in the Age of Mechanical Reproduction, trans. J. A. Underwood, London: Penguin.

Canovan, M. (1999). 'Trust the People! Populism and the Two Faces of Democracy,' Political Studies, Vol. 47, pp. 2-16.

Canovan, M. (2002). 'Taking Politics to the People: Populism as the Ideology of Democracy,' in Y. Mény and Y. Surel (eds), Democracies and the Populist Challenge, London: Palgrave Macmillan, pp. 25-44.

Carothers, T. (2002). 'The End of the Transition Paradigm,' Journal of Democracy, Vol. 13, No. 1, pp. 5-21.

Cherneski, J. (2017). 'An Unacknowledged Adversary: Carl Schmitt, Joseph Schumpeter, and the Classical Doctrine of Democracy,' Critical Review, Vol. 29, No. 4, pp. 447-472.

Collier, D. and S. Levitsky (1997). 'Research Note: Democracy with Adjectives: Conceptual Innovation in Comparative Research,' World Politics, Vol. 49, No. 3, pp. 430-451.

Collins, R. (1986). Weberian Sociological Theory, Cambridge: Cambridge University Press.

Dahl, R. A. (1956). A Preface to Democratic Theory, Chicago: University of Chicago Press.

Dahl, R. A. (1958). 'A Critique of the Ruling Elite Model,' American Political Science Review, Vol. 52, No. 2, pp. 463-469.

Dahl, R. A. (1961). Who Governs? Democracy and Power in an American City, New Haven: Yale University Press.

Faucci, R. (2007). 'Max Weber's Influence on Schumpeter,' History of Economic Ideas, Vol. 15, No. 1, pp. 111-133.

Frank, J. (2015). 'The Living Image of the People,' Theory \& Event, Vol. 18, No. 1, https://muse.jhu.edu/article/566086.

Freeden, M. (1996). Ideologies and Political Theory: A Conceptual Approach, Oxford: Clarendon Press.

Gerçek, S. E. (2017). 'From Body to Flesh: Lefort, Merleau-Ponty, and Democratic Indeterminacy,' European Journal of Political Theory, DOI: $10.1177 / 1474885117722075$.

Held, D. (2006). Models of Democracy, 3rd ed., Cambridge: Polity.

Herrera, C. M. (1995). 'Avant-propos,' in C.-M. Herrera (ed.), Le droit, le politique autour de Max Weber, Hans Kelsen, Carl Schmitt, Paris: L'Harmattan, pp. 7-11.

Herrero, M. (2015). 'On Political Theology: The Hidden Dialogue between C. Schmitt and Ernst H. Kantorowicz in The King's Two Bodies,' History of European Ideas, Vol. 41, No. 8, pp. 1164-1177.

Huntington, S. P. (1991). The Third Wave: Democratization in the Late Twentieth Century, Norman: University of Oklahoma Press.

Ionescu, G. and E. Gellner (eds) (1969). Populism: Its Meaning and National Characteristics, London: Weidenfeld and Nicolson.

Kalyvas, A. (2008). Democracy and the Politics of the Extraordinary: Max Weber, Carl Schmitt, and Hannah Arendt, Cambridge: Cambridge University Press.

Kantorowicz, E. H. (1957). The King's Two Bodies: A Study in Mediaeval Political Theology, Princeton: Princeton University Press.

Kelsen, H. (1921). 'Der Staatsbegriff der „,verstehenden Soziologie,“' Zeitschrift für Volkswirtschaft und Sozialpolitik, Vol. 1, pp. 104-119.

Kelsen, H. (1929). Vom Wesen und Wert der Demokratie, 2nd rev. ed., Tübingen: Mohr Siebeck. 
Kelsen, H. (1968). 'Demokratie,' in H. Klecatsky, R. Marcic and H. Schambeck (eds), Die Wiener rechtstheoretische Schule. Schriften von Hans Kelsen, Adolf Merkl, Alfred Verdross, Vol. 2, Vienna: Europa Verlag, pp. 1743-1776.

Krouse, R. W. (1982). 'Polyarchy and Participation: The Changing Democratic Theory of Robert Dahl,' Polity, Vol. 14, No. 3, pp. 441-463.

Laclau, E. (2005a). On Populist Reason, London: Verso.

Laclau, E. (2005b). 'Populism: What's in a Name?,' in F. Panizza (ed.), Populism and the Mirror of Democracy, London: Verso, pp. 32-49.

Lefort, C. (1986). The Political Forms of Modern Society: Bureaucracy, Democracy, Totalitarianism, ed. J. B. Thompson, Cambridge, MA: MIT Press.

Lefort, C. (1988). Democracy and Political Theory, trans. D. Macey, Minneapolis: University of Minnesota Press.

Lefort, C. (2012). Machiavelli in the Making, trans. M. B. Smith, Evanston: Northwestern University Press.

Lijphart, A. (1968). The Politics of Accommodation: Pluralism and Democracy in the Netherlands, Berkeley: University of California Press.

Lijphart, A. (1972). 'Toward Empirical Democratic Theory: Research Strategies and Tactics,' Comparative Politics, Vol. 4, No. 3, pp. 417-432.

Lijphart, A. (2008). Thinking about Democracy: Power Sharing and Majority Rule in Theory and Practice, London: Routledge.

Mommsen, W. J. (1974). Max Weber und die deutsche Politik 1890-1920, 2nd ex. ed., Tübingen: Mohr Siebeck.

Mouffe, C. (2005). The Democratic Paradox, London: Verso.

Mouffe, C. (2019). For a Left Populism, London: Verso.

Moyn, S. (2012). 'The Politics of Individual Rights: Marcel Gauchet and Claude Lefort,' in R. Geenens and H. Rosenblatt (eds), French Liberalism: From Montesquieu to the Present Day, Cambridge: Cambridge University Press, pp. 291-310.

Mudde, C. (2004). 'The Populist Zeitgeist,' Government and Opposition, Vol. 39, No. 4, pp. 541-563.

Müller, J.-W. (2016). What is Populism?, Philadelphia: University of Pennsylvania Press.

Oakeshott, M. (1996). The Politics of Faith and the Politics of Scepticism, ed. T. Fuller, New Haven: Yale University Press.

Osterhammel, J. (1987). 'Varieties of Social Economics: Joseph A. Schumpeter and Max Weber,' in W. J. Mommsen and J. Osterhammel (eds), Max Weber and His Contemporaries, London: Allen \& Unwin, pp. 106-120.

Pateman, C. (1970). Participation and Democratic Theory, Cambridge: Cambridge University Press.

Plotke, D. (2010). 'Is There Such a Thing as Minimal Democracy?', Western Political Science Association Meeting Paper (unpublished).

Przeworski, A. (1991). Democracy and the Market, Cambridge: Cambridge University Press.

Przeworski, A. (1999). 'Minimalist Conception of Democracy: A Defense,' in I. Shapiro and C. Hacker-Córdon (eds), Democracy's Value, Cambridge: Cambridge University Press, pp. 12-17.

Sartori, G. (1962). Democratic Theory, Detroit: Wayne State University Press.

Scheuerman, W. E. (2020). The End of Law: Carl Schmitt in the Twenty-First Century, 2nd ed., London: Rowman \& Littlefield. 


\section{Elitism, Populism and Pluralism}

Schmitt, C. (1963). Der Begriff des Politischen. Text von 1932 mit einem Vorwort und drei Corollarien, Berlin: Duncker \& Humblot.

Schmitt, C. (1988). The Crisis of Parliamentary Democracy, trans. E. Kennedy, Cambridge, MA: MIT Press.

Schmitt, C. (2010). Verfassungslehre, 10th ed., Berlin: Duncker \& Humblot.

Schumpeter, J. A. (1976). Capitalism, Socialism and Democracy, 5th ed., London: Allen \& Unwin.

Urbinati, N. (1998). 'Populism and Democracy,' Constellations, Vol. 5, No. 1, pp. $110-124$.

Walzer, M. (ed.) (1974). Regicide and Revolution: Speeches at the trial of Louis XVI, London: Cambridge University Press.

Weber, M. (1978). Economy and Society, ed. G. Roth and C. Wittich, Berkeley: University of California Press.

Weber, M. (1994). Political Writings, ed. P. Lassman and R. Speirs, Cambridge: Cambridge University Press.

Wright Mills, C. (2000). The Power Elite, new ed., New York: Oxford University Press. 


\section{Index}

Note: Page numbers followed by "n" denote endnotes.

absolutism 7, 9, 52, 79, 103, 156, 159-161

analytic political philosophy 2

anarchism 136, 168n33-34, 172n73

Anschütz, G. 122

anthropological pessimism 73, 90, 183

Antigone 6

Archiv für Sozialwissenschaft und Sozialpolitik 26, 99, 129, 143

Arendt, H. 60n56

aristocracy $7,45,49,80$

Aristotle 7-8, 158

asceticism 27, 29-30

authoritarianism 71, 127, 184, 186, 189,191

authority 4, 6-8, 15, 16n14, 21-22, $24,30-32,36-38,46,50,54,65-66$, 69-70, 73, 76, 78-80, 82-84, 86, 88-91, 93, 96, 100-101, 103, 127, $132,134,141-143,147,150-151$, 159-160, 171n57, 181; patriarchal authority $30-31$; personal authority 37, 55, 84, 181, 185-186; political authority 5, 7, 9, 37, 82, 91, 94, 103, 194; spiritual authority 8 ; traditional authority $36,59 \mathrm{n} 34,74$

autocracy 145, 148, 150, 152-153, 155, 157-158, 160-163, 169n38, 179

autonomy $33,44-45,69-71,99$, $101-102,119,121,125,127$, 132-133, 137, 140-141, 143, 146, $151,154,187-189,193,195$

axiological neutrality 29

Bakunin, M. 90, 92

balance of powers 52-53

Barth, K. 110n69

Basic Norm 104n5, 123, 137-141, 162, 169n37-39
Baumgarten, H. 59n44

Baxter, R. 29, 57n15-16

Beaud, O. 96, 111n 80

Begriffsgeschichte 88

Bendersky, J. W. 68

Bergson, H. 92

Bergsträsser, A. 99

Bernatzik, E. 122

Bismarck, O. 12, 43, 47, 67

Bodin, J. 7, 16n8, 78-79

Bolshevism 172n73

Bonald, L. d. 8, 16n12, 16n14, 17n15, 76, 88-89, 110n61

Bultmann, R. K. 110n69

Burckhardt, J. 28, 57n13

bureaucracy 12, 15, 31-32, 34, 36-39, 41-42, 46-48, 50, 54-55, 56n13, $58 \mathrm{n} 22,59 \mathrm{n} 42,60 \mathrm{n} 51,60 \mathrm{n} 56$, 71-72, 110n68, 152, 181-182; bureaucratization $23,42,47-49,51$, $54,59 \mathrm{n} 36,77,79,106 \mathrm{n} 22$

Burke, E. 10, 76, 88, 172n75

Caesarism 43, 49, 83, 110n61, 190-191, 194

Canon law 9, 39

capitalism 17n20, 26-30, 32, 41, 44, 48, 50, 56n10, 56n12, 57n16, 58n20, 72, $92,107 \mathrm{n} 31,110 \mathrm{n} 68,187$

Cassirer, E. 104n2, 109n50, 121, $166 \mathrm{n} 12,168 \mathrm{n} 23,169 \mathrm{n} 35$

Catholicism 9, 16n14, 44, 51, 59n36, 66-69, 82, 88-90, 104n 3, 106n22, 109 n60, 110n69, 111n80, 127, 167n17

causality $37,123-124,131$

charisma $21-22,25,32,36-43,46,48$, 51, 53-55, 59n 33, 59n 35, 60n 57 , 65-66, 83-84, 108n44, 181-182

Christ 10, 69, 157 
civitas maxima 155

Cohen, H. 104n4, 109n50, 123, 166n12, $167 \mathrm{n} 23,169 \mathrm{n} 38$

Cold War 1

Cole, G. D. H. 112n88

conservatism $10,13,17 \mathrm{n} 17,17 \mathrm{n} 19-20$, 29-30, 43, 51, 53, 66, 71, 73, 75, 89, 105n10, 106n21, 109n60, 122, 133, $144,152,155$

constituent power 79-80, 91, 94, 96-98, 186

constitutionalism 98, 113n96

Cortés, D. 88-90, 110n66

Cromwell, O. 102

crowd psychology 80, 106n29, 183, 198n11

Dahl, R. A. 191-192, 198n4, 199n20

Däubler, T. 71-73

decisionism 5, 24, 66-67, 69, 76, 86, 88-89, 91, 98

delegation $78,142,146,155,171 \mathrm{n} 57$

democracy 1-18, 21-23, 30, 45-46, 49, 53, 66-67, 77, 87-88, 91, 93-98, 103, 119-120, 140, 142-148, 151-154, 156-158, 160-165, 178-187, 189-199; cosmopolitan democracy 181; democratization 3, 14-15, 45, 47, 193, 198n10; liberal democracy 2-3, 12, 101, 103, 182, 198n10, 198n14, 199n30; modern democracy 3-5, 14, 21-23, 32, 46, 54-55, 66, 76, 98, 103, 119, 142, 144, 163-164, 178, 182, 186-187, 189-190, 194, 196-197, 198n14; parliamentary democracy 5, 45, 50, 65, 93, 119 , 144, 147, 150-152; plebiscitarian democracy 50

dictatorship 17n20, 66-67, 74-81, 83, 89-92, 96, 107n34, 110n67, 136, 143, 150, 152-153, 161; commissarial dictatorship 78, 82; military dictatorship 71 ; sovereign dictatorship 78, 80-81, 83, 91, $108 \mathrm{n} 42,111 \mathrm{n} 74$

division of labour 71, 151

divorce $8,16 \mathrm{n} 12,152$

domination 4, 21-23, 25, 31-32, 35-42, 45-46, 50, 54, 59n31, 59n35, 60n52, 77, 79-81, 83-84, 130, 135, 141, 144-145, 158, 160, 167n22, 180, 195-196; charismatic domination 46; non-legitimate domination $45,55 \mathrm{n} 4$; rational-legal domination 38-41, 46; traditional domination 38-39, 41

Durkheim, E. 134 economization 24, 90

Ehrlich, E. 125

Eisner, K. 33, 58n26

elitism 5, 48, 178, 180-181, 184, 190-191, 193

empiricism 23, 157

Enlightenment 1-2, 6, 8, 10, 29-30, 39, $53,79,90-91,97,153,156,162$

equality $46,94-95,112 \mathrm{n} 86,121$, 144-145, 159-161, 192-193, 196

fascism $1-2,93,111 \mathrm{n} 75,198 \mathrm{n} 12$ feudalism 39, 150; feudalization 13

Feuerbach, L. 134

Feyerabend, P. 168n33

First World War 4-5, 11, 15, 22, 34, 67, 70-71, 81, 110n69, 121-122

freedom 17n17, 32, 47, 55, 94, 96-97, 111n77, 144-146, 149-152, 160-161, 183, 193; individual freedom 30,47 , 146; political freedom $30,43,160$

French Revolution 6, 12-13, 23, 30, 91-92, 97, 107n 32, 121, 133

Freud, S. 132, 134, 161, 188-189, 199n19

Friedrich, C. J. 65

general will 7-9, 144-146

George, S. 42

Gerçek, S. E. 199n31

God 6, 8-10, 16n14, 72, 75-76, 78-80, 134-137, 146, 157, 169n38, 194

Gogarten, F. 110n69

Grundnorm see Basic Norm

Habermas, J. 65, 185

Habsburg Empire 15, 122

Hegel, G. W. F. 28, 56-57n13, 67-69, $74,92,104 \mathrm{n} 3,104 \mathrm{n} 7,106 \mathrm{n} 21,127$, $167 \mathrm{n} 17,169 \mathrm{n} 38$

Heidegger, M. 121

Held, D. 181

Heller, H. 144

Helmholtz, H. v. 122

Heraclitus 157

heredity 7-8, 11, 89

heteronomy $36,70,144$

historicism 25-26, 106n 21

Hitler, A. 12, 55, 60n57, 99

Hobbes, T. 79, 86, 89, 109n58, 147-148, 158, 163, 195

homogeneity 5, 81, 94-95, 98, 103, $107 \mathrm{n} 33,144,185,192,198 \mathrm{n} 12$

Honoratiorenpolitik 49

human rights 50, 149

Huntington, S. P. 198n10 
Husserl, E. 123, 165-166n8

hypostasis $135,144,146$

ideal type 4, 21-22, 32, 36-39, 45, 54, 56-57n13, 58n22, 84, 129, 131, 190,192

idealism 10, 28, 68, 70-71, 73, 158 ideology 9-10, 17n19, 23, 44, 93, 132-133, 143, 145, 151, 153, 155, $162,164-165,186-187,192$

immobilism 30

imperialism 17n20, 60n56, 102, 155, 166n14

imputation 57n14, 123-124, 137, 142, 162,195

indeterminacy 5, 120, 163-165, 194, 199n31

individualism 2, 70, 72, 97; methodological individualism 103, 132, 196, 199n19

inequality see equality

Innocent III 59n36, 77

institutionalism 34

interpretive sociology 24, 129-130, 180, $198 n 6$

irrationalism 2, 80, 85, 92, 94, $111 \mathrm{n} 73,161$

Jaffé, E. 26

Jaspers, K. 65

Jellinek, G. 99, 122, 130

Jesus see Christ

jus belli 100

justice 2, 4-5, 12, 32, 86, 121, 127, 139,161

Kafka, F. 59n42

Kaiserreich 12, 17n19, 121

Kalyvas, A. 186

Kant, I. 17n19, 28, 60n46, 68-70, 73-74, 85-86, 121-124, 131, 139, 157-158, 165n2-3, 166n9

Kantorowicz, E. H. 199n28

Kantorowicz, H. 125

Kaufmann, E. 144, 171n66

Keyserling, H. G. 30, 58n18

Kierkegaard, S. 85

kinship 8, 27, 30-31

Koselleck, R. 88, 109n58

Kulturkritik 72

Laclau, E. 188-190, 196, 199n19, 199n30-31

Lask, E. 104n7, 109n50, 124, 126, 128

Laski, H. 112n88

law of nature see natural law leadership 34, 43, 46, 48-49, 53, 161, 182,189

Le Bon, G. 106n29, 183, 189, 198n11

Lefort, C. 5, 194-197, 199n28, 199n30-31

legality $8,24,74,110 \mathrm{n} 61,130,134$, 137 ; rational legality $21,32,36-39$, 84,137

legitimacy $1,5-10,15,21-25,31-32$, 36-37, 46, 51, 66, 76, 88-89, 91, $130-131,133,137,141,180,188$, 197; democratic legitimacy 4, 14, 94; dynastic legitimacy 8-10, 75, 88-89; hereditary legitimacy 8,10 ; legitimation 1, 23, 78; legitimism 9, 23, 90

Leibniz, G. W. 157, 169n38

liberalism 2, 11, 13-14, 42-43, 66, 75, $81,90-91,93,140,143,151$

liberty 2, 121, 149

Lijphart, A. 192-193

Locke, J. 79, 85

logicism 123, 129-131, 155, 166n8

Löwith, K. 58n25, 102

Ludendorff, E. 50

Lukács, G. 65, 106n21

McCormick, J. P. 83-84

Machiavelli, N. 77, 79, 111n74, 195-196

Magna Charta 53

Maistre, J. d. 8-9, 16n14, 17n15, 76, 88-89

majority principle $150-151,156$

Mannheim, K. 10, 96, 106n21

Marx, K. 27-28, 30-31, 41, 58n20, 77, 91-92, 195

Marxism 90, 106n21, 155, 182, 188, 195

mass politics $14,48-49,77,80$

materialism 12, 26, 87, 91

Meier, H. 99, 102

Meinecke, F. 11

Menger, C. 56n9

Menzel, A. 122

Merleau-Ponty, M. 199n31

metaphysics 9, 75, 78-79, 87-88, 120, 124, 132-133, 137, 139-142, 149, 151-152, 154-155, 157-159, 163,191

Methodenstreit 26, 65n9

methodological syncretism 85 , 125-126, 131, 155

Michels, R. 29, 57-58n17, 65, 152

militarism 43, 71

Mills, C. W. 191 
miracle 86-87, 89, 136

modernity $1,4,6,11,13,15,21-22,26$, $28,31-32,41,53,55,71,73,79,154$, 179-181, 195; modernism 105n11

monarchy $12,50-51,140,184,187$; absolute monarchy $69,98,158$; constitutional/parliamentary monarchy $11,50-51,75$; divineright monarchy $17 \mathrm{n} 15,51,187$; patrimonial monarchy 41

monism 148, 154, 169n38

Moore, B. 17n20

moral philosophy 2-3

Morgenthau, H. 99, 101

Mouffe, C. 199n30, 113n96, 184-186, 188

Müller, A. 75

Müller, J.-W. 103

Mussolini, B. 93

Napoleon 10, 12, 17n17, 73

nationalism 3, 12, 42-45, 68, 93-94, $98,103,121$; methodological nationalism 14

Natorp, P. 104n4

natural law 6

naturalism 23, 146, 195

Nazism 12, 14, 102, 111n69, 182

neo-Kantianism 28, 44, 67, 68-71, 74, 85-86, 120-128, 130, 132, 138, 141, $143-144,158$

neoliberalism 3, 185

Nietzsche, F. 28-29, 42-43, 57n13, $57 \mathrm{n} 16$

nihilism 24, 66, 102-103, 160, 162

normativism 2, 13, 21, 23-24, 32, 34, 68-70, 74, 76-77, 85, 87, 89, 91, 122-131, 137-141, 146-147, 149, 154-156, 162-163, 165, 180-181, 183-184, 193

objectivity $22,25,28,30,75,86,90$, $92,125,131-133,145,154-155$, 159-161, 164

occasionalism 75, 102-103, 106n21

Old Regime 81, 194

oligarchy $58 \mathrm{n} 17,107 \mathrm{n} 32,152,191$

order 6, 9-10, 12, 21, 23-24, 40-41, 73-74, 78-80, 84-85, 89-93, $100-101,121,130,135-136,138$, 141-142, 144-146, 149, 152, 154, 156, 158, 160, 162-164, 186, 195; constitutional order $86,96,122$; international order 3,155 ; legal order $75,82,85-86,88,98$,
126-127, 129-130, 134-136,

140-142, 154-155; political order 10, $23,51,76,84,144-145,157$

original $\sin 90,110 \mathrm{n} 69$

pacifism $33,73,155$

papal infallibility 69,89

parliamentarism $14,42,45,48-49,93$, 150-152, 156; parliamentarization $14,45,50$

Parsons, T. 29, 56n11, 57n16, 58n22

Parteienstaat 149, 152

Peukert, D. J. K. 15, 18n23

phenomenology 166n8, 199n31

Pilate 157

Plato 59n39, 157; Platonism 139

plenitudo potestatis $59 \mathrm{n} 36,77,106 \mathrm{n} 22$

pluralism 5, 45, 93-94, 98-100, 103, 119-120, 141, 147-150, 152, 154, 156, 159-161, 163-165, 178, 185, 187, 190-194, 196-197

populism 3-5, 65-67, 98, 103, 178, 184-191, 194, 196-197

positivism $24,37,50,53,68,100-101$, $122,124,126,140-141,143,147$, $156,158,180,195-196$

pouvoir constituant see constituent power

Preuß, H. 52

progress $1,39,47,151,154,156,181$

prophecy 42

Protestantism 26-27, 29-30, 44, 56n10-11, 57n15, 67, 85

Proudhon, P.-J. 90, 92

psychologism 123, 165-166n8

pure theory of law $5,85,119-120$, $123,130,132-133,136-137,142$, $154-155,162$

pure type see ideal type

Puritanism see Protestantism

racism 102

Radbruch, G. 126-128, 167n17

Radkau, J. 41, 59n42

Rathenau, W. 72, 105n10

rationalism 2, 28, 38-39, 41, 53, 79, $85,88,91-92,123,151,155,158$, 161-162

rationalisation 155

rationality 73,183 ; instrumental rationality 40 ; strategic rationality 3 ; value-rationality 40

Rawls, J. 2-3, 16n4, 113n96, 185

Rechtssatz 122

Rechtsstaat 95-96, 140 
Redslob, R. 52

reine Rechtslehre see pure theory of law relativism 5, 24, 72, 87-88, 119-120,

$128,146-147,149,151-154$, $156-165,194$

representation $3,11,52,69,75,80$, 98, 142-143, 146, 150, 185-186, 196-197; proportional representation 149-150, 193

responsibility 46-47, 49

Rickert, H. 25, 104n7, 120, 124-128, $166 \mathrm{n} 10$

Rogers, M. D. 71, 73

romanticism 33, 75-76, 89, 103

Rousseau, J.-J. 7-9, 16n10, 23, 98, 144-148, 163, 170n50, 182, 198n12 rule of law 181

Sander, F. 169n35

Sartori, G. 198n4

Scheuerman, W. E. 99, 101, 198n12

Schlegel, F. 75

Schleiermacher, F. 11

Schluchter, W. 33

Schmoller, G. 56n9

scholasticism 139, 157, 169n38

Schumpeter, J. A. 181-184, 190-191, 198n9-10, 198n12

Schwab, G. 108n47

scientism 5, 88, 120, 156, 161, 163

Second World War 1, 11-12, 43, 161, 183, 191-192

secularization $75,78,82-84,86-87$, 91, 94

self-determination see autonomy

separation of powers 74

Siebeck, P. 143

Sieyès, E.-J. 79-80, 94, 96-97

Simmel, G. 93, 99, 122, 129

social contract 2, 145, 148

social Darwinism 43

socialism $2,15,28,43,51,68,90,99$, $143,181,187$

Sohm, R. 39

solipsism 103, 159-160, 172n73

Solzhenitsyn, A. 172n73

Sombart, W. 26, 56n 10

Sonderweg 11, 13-14, 43

Sorel, G. 92-93, 111n73

sovereignty $9,24,52,66-67,75,78-85$, 87-88, 95, 97, 99-102, 133, 135-136, 148, 154-156, 163, 186, 197; divine sovereignty 9; national sovereignty 154; popular sovereignty 6-7, 9,
$11,76,80,143,146$; royal

sovereignty 89

Spengler, O. 29, 105n10

Spinoza 157, 169n38; Spinozism 139

Staatslehre 34, 100, 135

Stalin, J. 55, 172n73; Stalinism 181

Stammler, R. 87, 104n4, 109n55

Ständestaat 29

state of exception $77,82,85-86,89$

state of nature 7, 146, 148-149, 195

state of siege/emergency 74, 82

Strauss, L. 66, 96, 99

Sulla 78, 83

technicization $24,86,90$

teleology $34,161-162,180$

theocracy 16-17n14, 41

theology 1, 9, 29, 66, 84, 86-90, 102, 133-136, 152, 155-156, 164, 190,

193; Christian theology 9, 39, 85,

135; political theology 9, 66, 88, 99, 102, 108n44, 134, 152, 164, 183, 194-195, 197

Third Reich 12

Thoma, R. 111n77

Tobler, M. 59n38

totalitarianism $17 \mathrm{n} 14,55,99,102$, $160,161,172 \mathrm{n} 73,181-182,187,189$, 194, 196

traditionalism $30,71,76,82,88-89$, $106 \mathrm{n} 21$

transcendental method 121 , 123-124, 162

Triepel, H. 148

tyranny $14,16 n 8,78-79$

universal suffrage $43,45,47,179$

universalism $1,50,140,155-156$

Vaihinger, H. 168n 32

Verstehen 13, 25, 129, 132, 180

violence $34,81,92,157,166 \mathrm{n} 9$, 180,185

Voegelin, E. 109n53, 166n9

Walter, R. 105n10

Weber, A. 59n42

Weimar 5, 13, 15, 66, 75, 94, 96, 102, 122, 127, 152, 186; Weimar constitution 77, 95-96, 147, 153; Weimar Republic 15, 51, 66, 74, 91, 96

Windelband, W. 104n2, 104n7, 122

Wundt, W. 166n8 


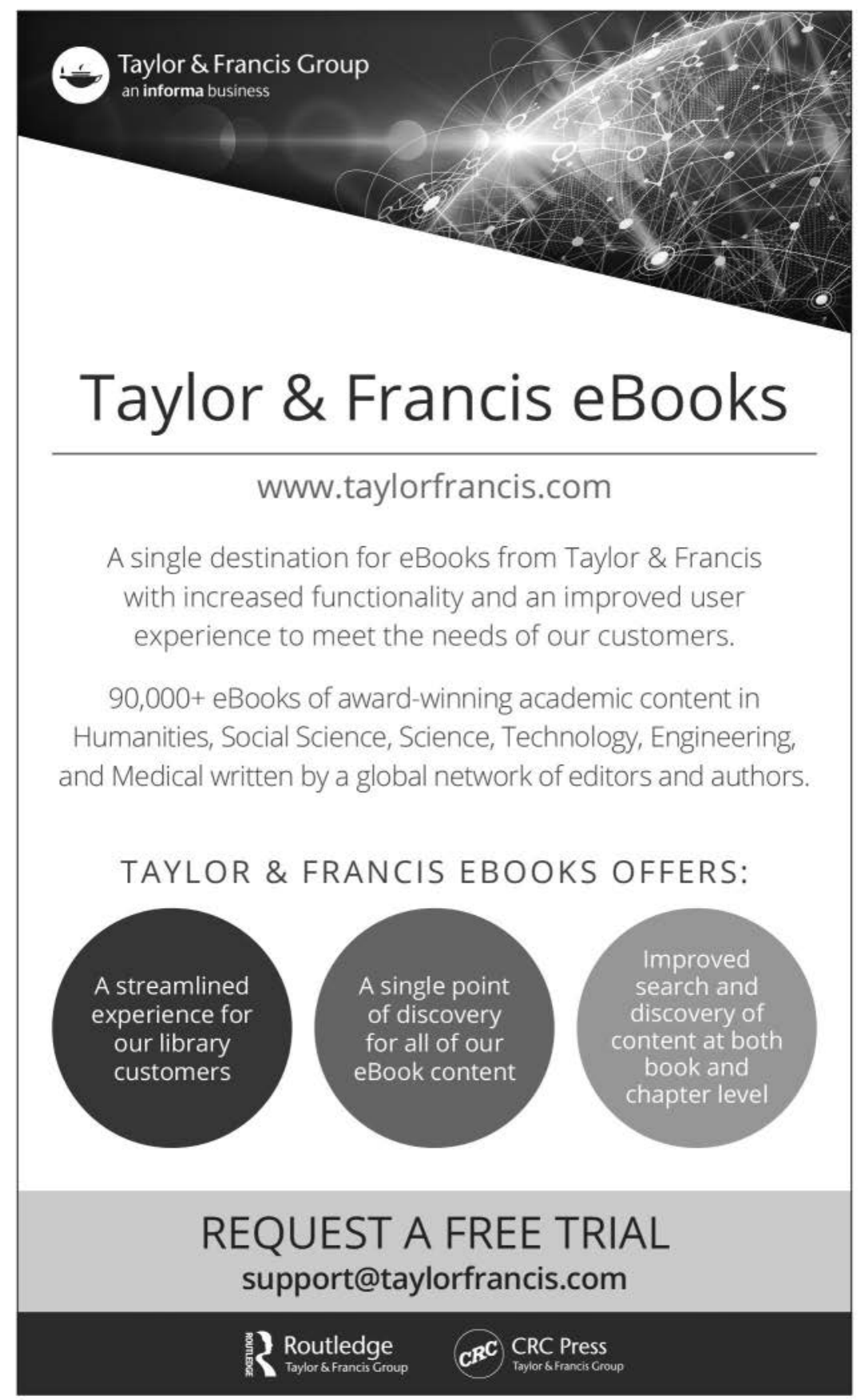

